73.21 13E U.S.Army Eoast. Eng. Res. Ctr.T.M. TM 34

$$
\left.\frac{(A D-766}{\text { T.M. } 39} 721\right)
$$

\title{
OCEAN DUMPING IN THE NEW YORK BIGHT:
} AN ASSESSMENT OF WHOTENVIRONMENTAL STUDIES DOCUMENT COI.LECTION

TECHNICAL MEMORANDUM NO. 39

$$
\text { MAY } 1973
$$

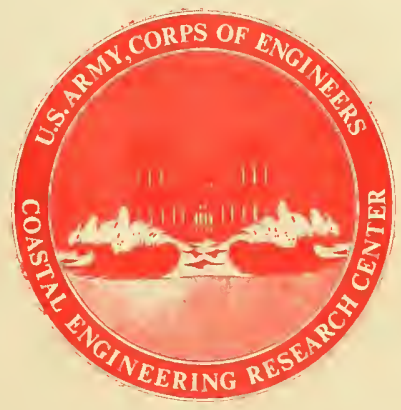

U.S. ARMY, CORPS OF ENGINEERS

COASTAL ENGINEERING

$G B$

450 RESEARCH CENTER

134

Approved for public release; distribution unlimited

no. 39 
Reprint or republication of any of this material shall give appropriate credit to the U. S. Army Coastal Engineering Research Center.

Limited free distribution within the United States of single copies of this publication was made by this Center. Additional copies are available from:

National Technical Information Service ATTN: Operations Division 5285 Port Royal Road Springfiezd, Virginia 22752

At the time of publication, prices were $\$ 3.00$ for hard copies and $\$ .95$ for microfiche copies.

Contents of this report are not to be used for advertising, publication, or promotional purposes. Citation of trade names does not constitute an official endorsement or approval of the use of such commercial products.

The findings in this report are not to be construed as an official Department of the Army position unless so designated by other authorized documents.

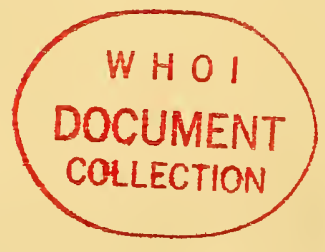




\section{OCEAN DUMPING IN THE NEW YORK BIGHT: AN ASSESSMENT OF ENVIRONMENTAL STUDIES}

by

George Pararas-Carayannis

TECHNICAL MEMORANDUM NO. 39 MAY 1973

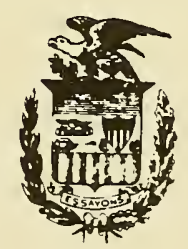

U.S. ARMY, CORPS OF ENGINEERS

\section{COASTAL ENGINEERING RESEARCH CENTER}

Approved for public release; distribution unlimited. 

Interdisciplinary short-term investigations related to the effects of ocean dumping in the New York Bight were contracted by the Coastal Engineering Research Center (CERC) as directed by Office, Chief of Engineers. Studies made by the Sandy Hook Laboratory of the National Marine Fisheries, the State University of New York at Stony Brook, the Woods Hole Oceanographic Institution, and the Sperry Rand Corporation were reviewed by a special advisory committee established by the Smithsonian Institution at CERC's request. The studies included hydrographic, geological, chemical, biological investigations, and a feasibility study for a remote-controlied electronic sensing system that could assist regulating agencies in detecting the location and dump status of waste disposal vessels operating in the Bight. Circulation patterns were estimated from data obtained by current meters and by seabed and surface drifters. Chemical analyses were made of the concentration of phosphorus (ortho, organic, meta, and total), nitrate, total iron, dissolved oxygen, and chlorophyl-a in water samples. Temperature, salinity, turbidity and $\mathrm{pH}$ were measured. Sediment samples were analyzed for organic content and the heavy metals, copper, chromium, lead, silver, nickel and zinc. Selected biological samples were analyzed for heavy metals and mercury. Biological investigations included studies of benthic meiofauna and macrofauna, zooplankton, finfish and bacteria. The studies include basic data related to the disposal of sewage sludge, dredge spoils and acid-iron wastes, and have helped provide a more detailed environmental description of the Bight dumping grounds and adjacent areas. The findings of these and other related studies are presented and analyzed in this report in terms of impact on ecology, water quality, and total environmental effects.

\section{FOREWORD}

Large quantities of dredge spoil, sewage sludge, and industrial wastes are dumped in federally designated areas of the New York Bight. Because of the frequency and quantity of disposal, the impact of ocean dumping on the marine environment was suspected to be significant. Concern over the environmental effects of waste disposal in the New York Bight prompted the Corps of Engineers to study offshore disposal activities. Long-term interdisciplinary investigations would be required to assess the long-term effects. However, interim studies of limited scope could provide guidance for a later comprehensive research program into the effects of dumping, a more detailed environmental description of the ocean dumping grounds, and determination of the distribution of waste materials in the Bight. CERC was instructed by OCE to contract studies to acquire the data necessary to permit such an assessment. The Smithsonian Institution, under contract with CERC, provided a plan outlining the elements of study and identified institutions qualified for all or part of this interdisciplinary investigation. To partly implement the program recommended by the Smithsonian Institution, CERC has (since 1967) contracted research studies with Sandy Hook Laboratory (SHL) of the National Marine Fisheries Service for interdisciplinary ecological studies of the dumping grounds, and with the Marine Sciences Research Center of the State University of New York at Stony Brook (SUNNY, SB) to undertake chemical studies of sewage sludge and dredge spoil deposits. A second contract with the Smithsonian Institution provided for a Scientific 
Advisory Committee (SAC) to advise, review and evaluate CERC-funded research studies of the disposal grounds in the New York Bight. An additional contract was signed with Woods Hole Oceanographic Institution (WHOI) to conduct a literature search and review of oceanographic know1edge of waste disposal practices for an area extending from Cape Cod to Cape Hatteras. Finally, a contract was let with Sperry Rand Company for a feasibility study of a system to provide remote surveillance of ocean dumping activities in the Bight. All the studies undertaken by CERC were concluded in May 1972, and final contract reports have been placed in the National Technical Information Service (NTIS) for public access.

The format of this report was selected to serve as a summary reference for interdisciplinary information related to the New York Bight. The data, where possible, have been summarized in tables or figures taken from contract reports, or have been recombined and condensed for clarity into new tables and figures.

Data from contract reports are reviewed and evaluated, and comments are made on their statistical significance and reliability as related to coverage of sampling, methods of analysis, and adequacy of treatment. Based on this analysis, an assessment is presented on the effects of ocean dumping on the marine environment of the New York Bight.

This report was prepared by George Pararas-Carayannis, Oceanographer, Design Branch, under the general supervision of Dr. D. B. Duane, Chief, Geology Branch, Mr. R. Jachowski, Chief, Design Branch, and Mr. G. M. Watts, Chief, Engineering Development Division. Particular appreciation is expressed to Dr. D. B. Duane for his initial guidance and thorough review of the final draft. Dr. D. B. Duane, Mr. S. J. Williams, and Mr. M. Field provided geologic information on the sediments of the New York Bight. Mr。S. J. Williams contributed significantly in the writing of the section in this report dealing with the geomorphology, stratigraphy and sediments.

Comments and reviews received from Lieutenant Colonel Don S. McCoy, Mr. T. Saville, Jr., Mr. G. M. Watts, Mr. R. Savage, Mr. R. Yancy, the Office of the Chief of Engineers, the North Atlantic Division, the New York District, and the Waterways Experiment Station, have been particularly helpful. Appreciation is also expressed to Dr. R. P. Higgins, Director, Oceanography and Limnology Program, Smithsonian Institution, Dr.D. K. Young, Chairman of the Smithsonian Advisory Committee, and the members of the Smithsonian Advisory Committee, Drs. M. A. Buzas, J. H. Carpenter, B. H. Ketchum, J. L. McHugh, V. J. Norton, D. J. O'Connor, and J. L. Simon for their review of the CERC-funded studies. CERC's environmental data collection studies in the New York Bight were started when Lieutenant Colonel Edward M. Willis was Director. At the time of publication of this report, Lieutenant Colonel Don S. McCoy was Director of CERC and Mr. T. Saville, Jr., was Technical Director.

This report is published under authority of Public Law 166, 79th Congress, approved 31 July 1945, as supplemented by Public Law 172, 88th Congress, approved 7 November 1963. 
ABSTRACT ............................. ii

FOREWORD . . . . . . . . . . . . . . . . . i ii

CONTENTS ...................... . . $v$

LIST OF FIGURES. . . . . . . . . . . . . . . . vii

LIST OF TABLES .................. . . . . .

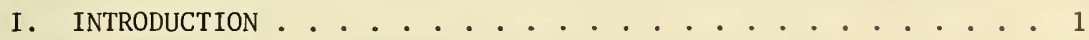

1. Summary of Legislation Related to Ocean Dumping. . . . . 1

2. Background ............... 3

3. Objectives and Scope of Studies........... 9

4. Chronology of Events ............. 10

5. Contract Studies . . . . . . . . . . . 13

II. EFFECTS OF OCEAN DUMPING IN OTHER AREAS. . . . . . . . 17

1. Rhode Island Sound ............... 17

2. Delaware Bay ............... 18

3. Chesapeake Bay ............... 19

4. Southeast Florida. . . . . . . . . . 20

5. Southern California. ............. 21

6. San Francisco Bay. . . . . . . . . . . . 23

7. Puget Sound. . . . . . . . . . . . . 25

8. Great Lakes. . . . . . . . . . . . . 26

9. Other Countries. . . . . . . . . . . . 26

III. THE NEW YORK BIGHT ENVIRONMENT . . . . . . . . . . 28

1. Bottom and Subbottom Characteristics ....... 28

2. Water Motion and Circulation Characteristics ..... 36 


\section{CONTENTS - Continued}

Page

3. Chemical Characteristics ............ 50

4. Biological Characteristics . . . . . . . . . 78

IV. DISCUSSION . . . . . . . . . . . . . . 109

1. Dispersion and Movement of Waste Materials . . . . 109

2. Effects of Ocean Dumping on Water and Sediment

Characteristics. . . . . . . . . . . 112

3. Effects of Ocean Dumping on Regional Ecology . . . . . 127

4. Sources of Coastal Pollution in the New York

Bight. ................. 139

5. Remote Sensing and Surveillance System for

Ocean Dumping Operations .............. 143

6. Alternate Ocean Dumping Sites. . . . . . . . . 144

7. Alternatives to Ocean Dumping. . . . . . . . . . 144

V. SUMMARY \& CONCLUSIONS. . . . . . . . . . . . . 146

LITERATURE CITED . . . . . . . . . . . . 151 
N. Y. Bight Dumping Grounds.

2 Northeastern Coastal Sector of the United States

Including the New York Bight . . . . . . . . 29

3 Recent Bathymetry of the Continental Shelf

Outside New York Harbor. . . . . . . . . . 30

4 Bathymetry of the Continental Shelf Outside New

York Harbor, based on an 1845 Survey ........ 31

5 Isopach of Fill Material ........... 32

6 Track of Geophysical Reflection Studies and

Location of Core, Boring and Sampling Sites

of CERC's Inner Continental Shelf Study

Program (ICONS).................. 33

7 Stratigraphy of Sediments in the Vicinity of the

Dumping Grounds as Revealed from Cores and

Subbottom Profiling Studies. . . . . . . . . 35

8 Sediment Distribution in Lower New York Bay and on

the Continental Shelf Outside New York Harbor. . . . 37

9 The Sandy Hook Laboratory's Hydrographic Stations. . . 40

10 Time History of Drifter Returns. . . . . . . . 42

11 Net Currents in Raritan and Lower Bays . . . . . . 4 43

12 Surface Drifter Returns \& Total Percent Recovery

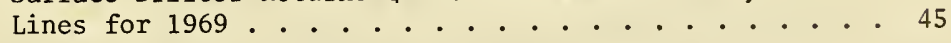

13 Origin of Surface Drifters Recovered on Long Island ................... 45

14 Origin of Surface Drifters Recovered on New Jersey Coast ............... . 45

15 Progressive Vector Representation of Current Meter Data from Stations A, B, and C of Sandy Hook Laboratory. . . . . . . . . . . 47

16 Seabed Drifter Returns: Tota1 Percent Recovery Lines for 1969 .................... 48 


\section{LIST OF FIGURES - Continued}

Figure

17 Origin of Seabed Drifters Recovered in Hudson Estuary Expressed and Contoured as Percentages of All Returns from Individual Stations . . . . . . .

18 Origin of Seabed Drifters Recovered on Long Island. . . . . . . . . . . . . . . . .

19 Origin of Seabed Drifters Recovered on New Jersey Coast. . . . . . . . . . . . . . . .

Stations Occupied by the SHL for Chemical Studies . .

21 Seasonal Variation of Certain Physical Chemical

Properties at Two Stations in the New York Bight. . .

22 Dissolved Oxygen Content of Surface Water and

Water 3 Feet off the Bottom in a Section Extending Seaward from the Coast of New Jersey. . . . . . . .

23 Median Concentration Value Range, and Limits for 70 Percent of Samples Analyzed for Surficial Samples in New York Harbor and New York Bight . . . .

24 Distribution of Total Copper Concentrations in Surficial Sediments and Waste Deposits in the New York Bight, Determined by SUNY-SB . . . . . . .

25 Distribution of Total Chromium Concentrations in Surficial Sediments and Waste Deposits in the New York Bight, Determined by SUNY-SB . . . . . .

Distribution of Total Lead Concentrations in Surficial Sediments and Waste Deposits in the New York Bight, Determined by SUNY-SB . . . . . . . 65

27 Distribution of Total Silver Concentrations in Surficial Sediments and Waste Deposits in the New York Bight, Determined by SUNY-SB . . . . . . .

28 Total Copper as ppm of Dry Sediment Through November 1971 (After SHL, 1972) . . . . . . . . 68

29 Total Chromium as ppm of Dry Sediment Through November 1971 (After SHL, 1972) . . . . . . . . .

Total Lead as ppm of Dry Sediment Through November 1971 (After SHL, 1972) . . . . . . . . . 70 


\section{LIST OF FIGURES - Continued}

Figure

$\underline{\text { Page }}$

31

32

Total Nickel as ppm of Dry Sediment Through

November 1971 (After SHL, 1972) . . . . . . . . . 71

2 Total Zinc as ppm of Dry Sediment Through

November 1971 (After SHL, 1972). . . . . . . . . 72

33 Loss-on-Ignition for Deposits from the

New York Bight . . . . . . . . . . . . . . 75

34 Total Carbon Concentrations in Deposits from

the New York Bight . . . . . . . . . . . . 76

35 Distribution of Carbon-Rich Deposits in the

New York Harbor and Carbon-Rich Waste Deposits

on the Continental Shelf Near the Harbor . . . . . . . 77

36 Total Iron ( $\mu g-a t / 1)$ Surface, Average by Station . . . . 79

37 Total Iron ( $\mu \mathrm{g}-\mathrm{at} / 1)$ Bottom, Average by Station. . . . 79

38 Total Iron ( $\mu g-a t / 1)$ Mid-depth, Average by Station . . . 80

39 Stations Occupied by SHL for biological sampling . . . . 81

40 Distribution and Abundance of Surf Clams

(Spisula Solidissima). . . . . . . . . . . . 9 91

41 Distribution and Abundance of Rock Crab

(Cancer Irroratus) . . . . . . . . . . . . . 92

42 Locations of Stations Sampled for Zooplankton

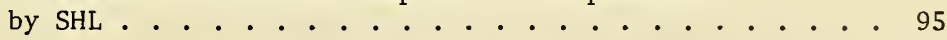

43 Total Copepods at Station 67 of SHL. . . . . . . . . 98

44 Total Copepods at Station 70 of SHL

(sewage dumping grounds) . . . . . . . . . . . 99

45 Total Copepods at Station 72 of SHL. . . . . . . . . 100

46 Total Copepods at Station 75 of SHL. ......... . 101

47 Total Copepods at Station 76 S of SHL . . . . . . . . 102

48 Total Copepods at Station 78 of SHL. . . . . . . . . 103 


\section{LIST OF FIGURES - Continued}

Figure

Page

49 Zooplankton Population (Average of Surface, Middle and Bottom Counts). . . . . . . . . . 104

50 Analysis of Coliform in Sediment Through December 1971.................. 107

\section{LIST OF TABLES}

Table

1 Historical Trends of Ocean Dumping 1949-1968 . . . . . 4

2 Types and Amounts of Waste Materials Disposed of by Ocean Dumping, 1968. . . . . . . . . . . . 5

3 Amounts of Waste Disposed of in the Ocean Dumping Grounds of the New York Bight. . . . . . . 6

4 Physical Properties of Sediments Dredged in the New York Metropolitan Area. . . . . . . . . 38

5 Ranges of Chemical Data Measurement near the New York Dumping Grounds . . . . . . . . . . . 52

6 Abundance of Major Elements in Typical Sewage Sludge and Natural Sediment Deposits . . . . . . . 58

7 Spectrochemical Analyses of Sewage Sludges, New York Metropolitan Region . . . . . . . . . . 59

8 Heavy Metals Concentrations in Sewage Sludge and Dredge Spoils... . . . . . . . . . . 60

$9 \quad$ Estimated Amounts of Oxidizable Carbon and Potentially Troublesome Elements Discharged with Various Waste Solids in Offshore Disposal Sites, New York Metropolitan Region. . . . . . . . 61

10 Some Chemical Properties of Sewage Sludges New York Metropolitan Region . . . . . . . . . . 73

11 Percent Total Carbon Composition of the Suspended Solid Material in Sewage . . . . . . . . 73

12 Species Diversity at Sampling Stations Within and Outside the Disposal Areas . . . . . . . . . 82 


\section{LIST OF TABLES - Continued}

Table

Page

13 Composition of Meiofaunal Communities at

Selected Stations in and around the Sewage

Sludge and Dredge Spoil Disposal Grounds . . . . . . 86

14 Comparison of Abundance of the Gammarid

Amphipod Populations in the Bight. . . . . . . . . . 87

15 Benthic Macrofaunal Species Sampled at the

Dumping Grounds and Adjacent Areas of the

N. Y. Bight. . . . . . . . . . . 88

16 Distribution and Abundance of Three Dominant

Organisms in the Waste Disposal Areas. . . . . . . . 93

17 Range in Number of Copepods Per Cubic Meter Found

by Other Investigators in the Middle Atlantic Area . . . 97

18 Copepod Mortality at Different Acid-Sea Water

Dilutions. . . . . . . . . . . . . . 136

19 Sewage Discharges in the New York-New Jersey

Region of the Bight. . . . . . . . . . . . . 141

20 Sediment Discharge of some U.S. Atlantic

Coast Rivers ... . . . . . . . . . . . 142

21 Suspended Solids Discharged by Some Major Rivers . . . . 142 

OCEAN DUMPING IN THE NEW YORK BIGHT:

AN ASSESSMENT OF ENVIRONMENTAL STUDIES

by

George Pararas-Carayannis

\section{SECTION I. INTRODUCTION}

\section{Summary of Legislation Related to Ocean Dumping}

Little legislation controlled ocean dumping until passage of the Marine Protection, Research and Sanctuaries Act in October 1972, dumping. Section 13 (Refuse Act) of the River and Harbor Act of March 3, 1899, (33 USC 407) authorizes the Secretary of the Army to controll by permit the discharge or depositing of refuse into navigable waters of the United States. This applies to the territorial seas, but it is not applicable to dumping in the oceans.

Similarly, Section 4 of the River and Harbor Act of 1905 provides for regulations on disposal of certain types of refuse matter in territorial seas. This authority was used by the Corps of Engineers in establishing dumping grounds.

The New York Harbor Act of June 29, 1888, as amended (33 USC 441 et seq), provides for the issuance of permits by the Supervisors of the New York, Baltimore, and Hampton Roads Harbors for the transportation upon and/or discharge in those harbors of a variety of materials including dredgings, sludge and acid. The District Engineers of New York, Baltimore and Norfolk have been designated the Supervisors of these harbors respectively.

A number of laws enacted since 1905 provided for environmental considerations of water quality and therefore relate indirectly to ocean dumping. The Public Health Service Act of 1912 and the Oil Pollution Act of 1924 (Public Law 68-238) are two such public laws.

In 1948, the Water Pollution Control Act (PL 80-845) was aimed specifically at enhancing water quality and value of water resources and establishing a national policy for the prevention, control, and abatement of water pollution. This law also established the Federal Water Pollution Advisory Board.

The Water Pollution Control Act Extension of 1952 (Public Law 82579 ) extended the duration of the Water Pollution Control Act for 8 years. The Federal Water Pollution Control Act of 1956 (Public Law 84660 ) promoted Federal-State cooperation in developing programs supporting research, and modified and simplified enforcement measures for controlling pollution of interstate waters. 
Public Law 87-88, passed in 1961, was an amendment of the basic Federal Water Pollution Control Act of 1956 which extended pollution abatement to navigable interstate and coastal waters, and the 0il Pollution Control Act, passed the same year (Public Law 87-167), implemented the provisions of the 1954 International Convention for the Prevention of the Pollution of the Sea by Oil.

In addition to water quality legislation, the Fish and Wild1ife Coordination Act, of 1965, amended and revised earlier versions of legislation dealing with conservation of living marine and wildlife resources, and emphasized the importance of harmonious planning, development, maintenance, and coordination of wildlife conservation with other features of water resource development.

Subsequent amendments to the basic water pollution control laws were the Water Quality Act of 1965 (Public Law 89-234), the Clean Water Restoration Act of 1966 (Public Law 89-753), and the Water Quality Improvement Act of 1970 (Public Law 91-224). The National Environmental Policy Act of 1969 (Public Law 91-190) specified as a national policy additional guidelines of environmental quality, and established the Council on Environmental Quality (CEQ) in the Executive Office of the President. Section 102 of the National Environmental Policy Act directs all Federal agencies to prepare statements of environmental impact on all major actions having a significant impact on the quality of the human environment.

The Water Quality Improvement Act of 1970 provided legislation to control oil pollution, and the discharge of hazardous substances into the waters of the United States. The Act provides procedures for the abatement of pollution which violates water quality standards, endangers the ecology, or damages important marine economic resources. An important provision of this Act is the creation of the Office of Environmental Quality to provide support to the Council of Environmental Quality, established pursuant to Public Law 91-190.

As indicated above, ocean dumping was, until recently, controlled in the New York Bight by the Corps of Engineers through the 1899 River and Harbors Act, the 1905 River and Harbor Act and the 1888 New York Harbor Act. Because of the navigational aspects of these statutes, the role of the Corps of Engineers and its authority to consider the environmental factors of ocean dumping have been contested.

In 1972, New York State sought court action against the Department of the Army (U. S. District Court, Southern District of New York, 12 January 1972), claiming that permits to dump in the ocean are issued as a matter of routine and no evaluation is made of the effects of dumping upon the environment. Sections 102 (a) and 102 (b) of the National Environmental Policy Act i:ere interpreted by the State of New York as not being sufficiently clear, entitling the State to mandamus compelling the Army Corps of Engineers to consider pollution effects prior to permitting dumping of sewage sludge and dredge spoil in the New York Bight. The court decided that the Corps of Engineers had indeed recognized the 
importance of the problem of ocean dumping and had initiated studies through its Coastal Engineering Research Center. (Studies summarized in this report) The court furthermore refused to interfere at this stage while the environmental criteria are still uncertain, evaluations on the effects of ocean dumping are continuing and additional legislation is pending.

Additional legislation has now been enacted on ocean dumping. The Marine Protection, Research and Sanctuaries Act of 1972 (Public Law 92532), was enacted 23 0ctober 1972. This law has the following major provisions: Section 101 of the law bans the transportation for the purpose of dumping and the dumping of radiological, chemical, and bacteriological warfare agents and high-level radioactive wastes; Section 102 authorizes EPA to issue permits for the transportation and dumping of all other material except dredged and fill material and to establish criteria for reviewing and evaluating such permits and designating sites and times for dumping; Section 103 authorizes the Corps of Engineers to issue permits, or regulations for Federal projects, for the transportation of dredged material for ocean dumping according to criteria established by EPA; Section 107 authorizes the Coast Guard to conduct surveillance of dumping activities and enforcement of regulations; finally, Sections 201, and 202, authorize the Department of Commerce (NOAA) to initiate a comprehensive and continuing program of monitoring and research regarding the effects of ocean dumping.

This recent legislation is now the comprehensive legislation on control of ocean dumping.

\section{Background}

a. Trends of Ocean Dumping. Trends of ocean dumping activities along the Atlantic, Gulf and Pacific coasts since 1949 through 1968 are illustrated in Table 1. The figures do not include dredge spoils or special waste materials such as radioactive wastes and military explosives. Nonetheless these figures indicate an increase in the yearly average quantity of waste materials disposed of in U. S. coastal areas.

The relative quantities and types of waste materials, including dredge spoils, disposed of by ocean dumping during a single year (1968) along the Atlantic, Gulf and Pacific coasts are given in Table 2. This table shows that dredge spoils constitute the largest percentage of waste materials disposed of $(84 \%)$.

Also, more than $62 \%$ of all ocean dumping occurs along the Atlantic coast of the United States. Table 3 gives the quantities of materials disposed of in the dumping areas of the New York Bight during the years 1965 through 1970. These quantities are given by volume (cubic yards) instead of weight (tons). By considering bulk densities of some of the waste materials (about $1.1 \mathrm{~g} / \mathrm{cm}^{3}$ for mud and cellar dirt, $1.3 \mathrm{~g} / \mathrm{cm}^{3}$ for dredge spoils, and $1 \mathrm{~g} / \mathrm{cm}^{3}$ for sewage sludge), we may conclude from Table 
Table 1. Historical Trends of Ocean Dumping, 1949-1968*

\begin{tabular}{|c|c|c|c|c|c|c|c|c|}
\hline \multirow[t]{2}{*}{ Area } & \multicolumn{2}{|c|}{$1949-1953$} & \multicolumn{2}{|c|}{$1954-1958$} & \multicolumn{2}{|c|}{$1959-1963$} & \multicolumn{2}{|c|}{$1964 J_{1968}$} \\
\hline & Total & Avg./Yr. & Total & Avg./Yr. & Total & Avg./Yr. & Total & Avg./Yr. \\
\hline Atlantic & $8,000,000$ & $1,600,000$ & $16,000,000 \dagger$ & $3,200,000$ & $27,270,000$ & $5,454,000$ & $31,100,000$ & $6,200,000$ \\
\hline Gulf $\ddagger$ & 40,000 & 8,000 & 283,000 & 56,000 & 860,000 & 172,000 & $2,600,000$ & 520,000 \\
\hline Pacific & 487,000 & 97,000 & 850,000 & 170,000 & 940,000 & 188,000 & $3,410,000$ & 682,000 \\
\hline Total & $8,527,000$ & $1,705,000$ & $17,133,000$ & $3,426,000$ & $29,070,000$ & $5,814,000$ & $37,110,000$ & $7,422,000$ \\
\hline
\end{tabular}

* Figures do not include dredge spoils, radioactive wastes, and after Train, Cahn and MacDonald, 1970 military explosives.

† Estimated by fitting a linear trend line between data for preceding period and data for succeeding period.

$\ddagger$ Disposal operations in the Gulf of Mexico began in 1952. 
Table 2. Types and Amounts of Waste Materials Disposed of by Ocean Dumping, 1968

\begin{tabular}{|c|c|c|c|c|c|}
\hline Material & $\begin{array}{l}\text { Atlantic } \\
\text { (tons) }\end{array}$ & $\begin{array}{l}\text { Gulf } \\
\text { (tons) }\end{array}$ & $\begin{array}{r}\text { Pacific } \\
\text { (tons) }\end{array}$ & $\begin{array}{l}\text { Total } \\
\text { (tons) }\end{array}$ & Percent \\
\hline Dredge Spoils & $30,880,000$ & $13,000,000$ & $8,320,000$ & $52,000,000$ & 84 \\
\hline Industrial Wastes & $3,013,200$ & 696,000 & 981,300 & $4,690,500$ & $<9$ \\
\hline Sewage Sludge & $4,477,000$ & 0 & 0 & $4,477,000$ & 7 \\
\hline $\begin{array}{l}\text { Construction and } \\
\text { Demolition Debris }\end{array}$ & 574,000 & 0 & 0 & 574,000 & $<1$ \\
\hline Solid Waste & 0 & 0 & 26,000 & 26,000 & $<1$ \\
\hline Explosives & 15,200 & 0 & 0 & 15,200 & $<1$ \\
\hline Miscellaneous & 0 & 0 & 200 & 200 & $<1$ \\
\hline Total & $38,959,400$ & $13,696,000$ & $9,327,500$ & $61,782,900$ & 100 \\
\hline
\end{tabular}

after Smith and Brown, 1971 


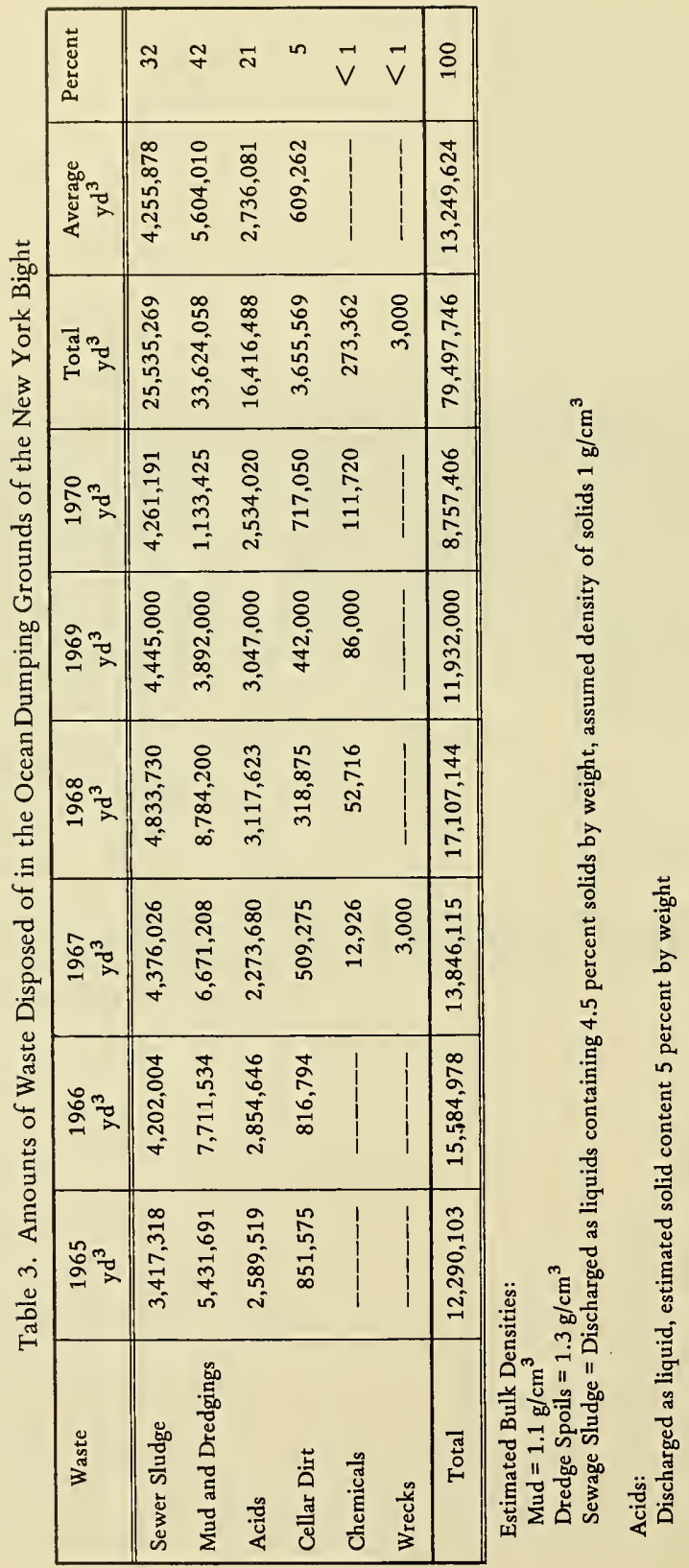


2 that the New York Bight dumping grounds, in 1968, received roughly $40 \%$ of the waste materials disposed in the Atlantic or roughly $27 \%$ of the total for the U. S. In 1968, however, the quantity disposed of by ocean dumping in the Bight was in excess of the yearly average.

b. History and Description of Ocean Dumping Sites in the Bight. The disposal areas in the Atlantic Ocean off the entrance to New York Harbor were established by the Supervisor of New York Harbor under authority of Section 1 of the Act of Congress approved 29 June 1888 (33 U.S.C. 411). (Figure 1). The disposal areas for mud, cellar dirt, stone, and wrecks were established many years ago in locations where it was considered that they would not be hazardous to navigation.

The disposal area for sewer sludge was selected in 1924 to avoid interference with navigation and to avoid offensive discoloration and solids washing up on the beaches.

The waste acid disposal area was established in April 1948 after detailed discussions with the Interstate Sanitation Commission, the New Jersey State Departments of Health and Fish \& Game, the New York State Departments of Conservation and Health, the Commercial and Sport Fisheries Bureaus of the U. S. Fish and Wildlife Service, the Food and Drug Administration of the U. S. Department of Health, and the Atlantic States Marine Fisheries Commission.

A brief description of the disposal grounds and their use, condensed from Wuesterfeld (1968), is as follows:

(1) Mud Dumping Ground: is located at a point not less than 7 nautical miles bearing $120^{\circ}$ True from Sandy Hook Light at Latitude $40^{\circ}$ $23^{\prime} 48^{\prime \prime}$ North and Longitude $73^{\circ} 51^{\prime} 21^{\prime \prime}$ West. Material dredged from the channels, anchorages and vessel berths in the port areas of the Bight, is disposed of in this area. The material is transported in dump scows owned and operated by dredging and marine construction contractors and in Corps of Engineers seagoing hopper dredges.

(2) Cellar Dirt Dumping Ground: is located at a point not less than 9 nautical miles bearing $118^{\circ} 30^{\prime}$ True from Sandy Hook Light at Latitude $40^{\circ} 22^{\prime} 5^{\prime \prime}$ North and Longitude $73^{\circ} 48^{\prime} 40^{\prime \prime}$ West. The material disposed of in this area consists primarily of earth and rock from cel1 ar excavations and broken concrete, rubble and other non-floatable debris from building demolition and highway construction work originating in the Borough of Manhattan. The material is transported to this area in dump scows owned by marine contractors and towing companies.

(3) Sewer Sludge Dumping Ground: is located offshore of a point not less than 11 nautical miles, $103^{\circ}$ True from Sandy Hook Light at Latitude $40^{\circ} 25^{\prime}$ '04' North and Longitude $73^{\circ} 44^{\prime} 5^{\prime \prime}$ 'West. The sewage wastes are either in raw or treated state or are in a digested form. Sewage wastes are disposed of at this dumping ground by the City of New 


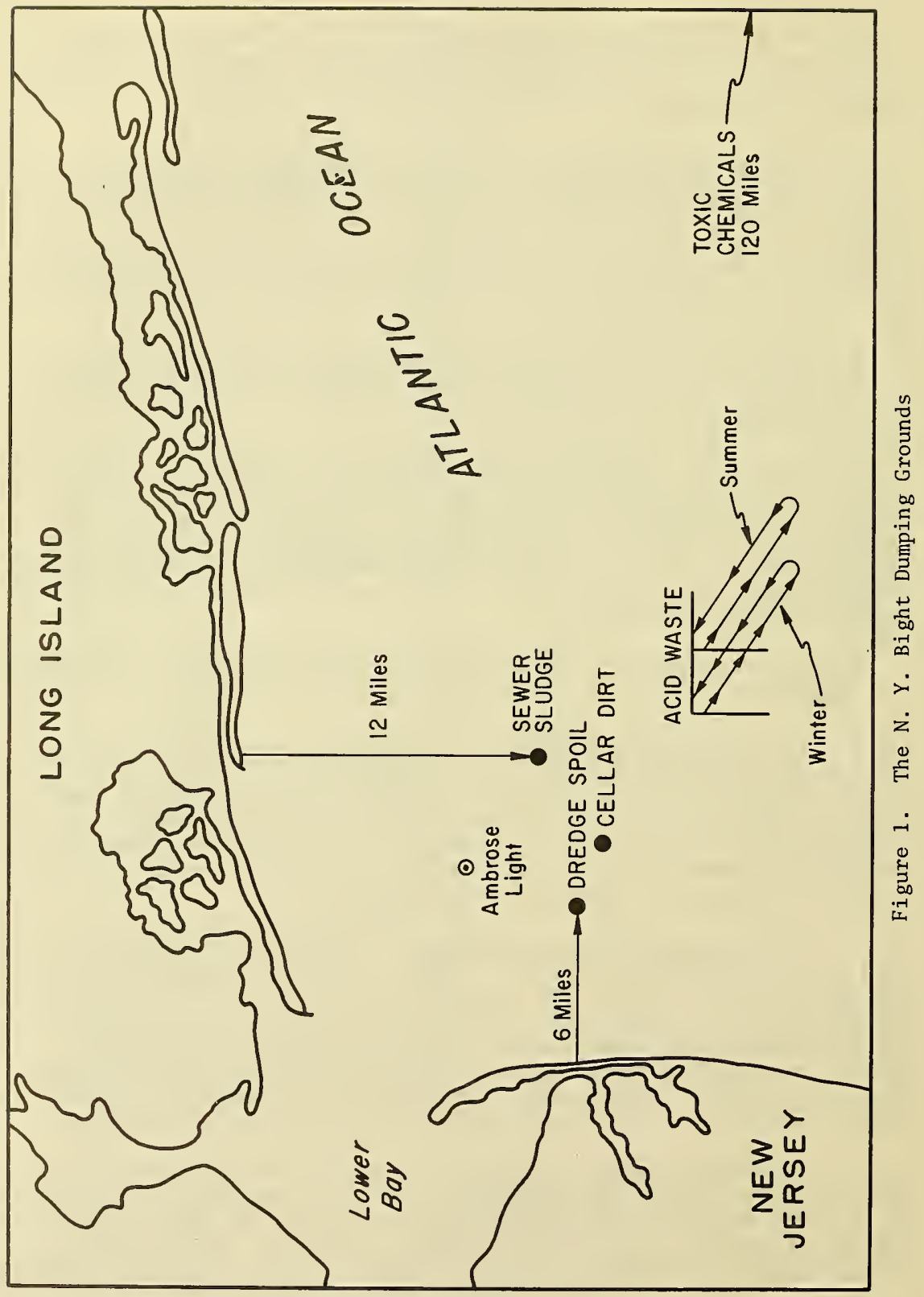


York, the cities of Glen Cove and Long Beach, New York, the counties of Nassau and Westchester, New York, the Passaic Valley Sewerage Commission, the Linden-Roselle Sewerage Authority, the Joint Meeting Sewage Disposal Commission, Elizabeth, New Jersey and the Middlesex County Sewerage Authority.

(4) Wreck Dumping Ground: is located at a point not less than 13 miles $66^{\circ}$ True from Sea Girt Light at Latitude $40^{\circ} 13^{\prime} 32^{\prime \prime}$ North and Longitude $73^{\circ} 46^{\prime} 02^{\prime \prime}$ West. Wrecks of vessels are intermittently disposed of in this area by marine contractors for the owners of vessels or for the Federal Govermment where the removal of sunken vessels is undertaken in navigable waters by the Corps of Engineers under Section 19 or 20 of the River and Harbor Act of 3 March 1899 (33 U.S.C. 414 and 415).

(5) Waste Acid Dumping Ground: is located southeast of a point about 16.3 nautical miles, $120^{\circ}$ True from Sandy Hook Light. During the summer, the area is south of Latitude $40^{\circ} 20^{\prime}$ North and east of Longitude $73^{\circ} 40^{\prime}$ West; during the winter, the area is south of Latitude $40^{\circ}$ $20^{\prime}$ North and east of Longitude $73^{\circ} 43^{\prime}$ West.

(6) Chemical Dumping Ground: is located about 120 nautical miles southeast of New York within an area bounded on the north by Latitude $39^{\circ}$ North, on the south by Latitude $38^{\circ} 30^{\prime}$ North, on the east by Longitude $72^{\circ}$ West and on the west by Longitude $72^{\circ} 30^{\prime}$ West. Due to the high cost of transporting the material to this area, it has not been utilized, and other means of disposal of the wastes have been employed. Small quantities of toxic wastes and high explosives have been disposed of intermittently in past years at a point 115 nautical miles $127^{\circ}$ True from Sandy Hook Light, at Latitude $39^{\circ} 17^{\prime} 30^{\prime \prime}$ North and Longitude $72^{\circ}$ West. However, the nature and quantities of the wastes and their sources are not readily available.

\section{Objectives and Scope of Studies}

The Corps of Engineers, as part of its Civil Works, has been responsible for defining certain ocean areas as disposal grounds for various types of waste material, issuing permits to parties desiring to use these grounds for the disposal of certain types of wastes, and for disposing in the specified disposal grounds, spoils dredged from harbors and waterways.

Increasing concern over the effects of marine waste disposal in the New York Bight, prompted the Corps to study monitoring offshore disposal activities in the Bight to determine impact on the environment. The primary objectives of the Corps of Engineers in funding such research investigations were the following:

a. The determination of the impact of waste disposal activities in the Bight on water quality, safety, water use, ecology, fish and wildlife conservation, and recreation.

b. The development of scientific information that could assist the 
Corps with management decisions for regulating and monitoring effectively the disposal of wastes in the coastal waters of the Bight.

c. The acquisition and scientific interpretation of data that would permit the writing of an accurate Environmental Impact Statement on the effects of waste disposal on the marine environment of the Bight.

Topics that requred investigation were too numerous and complex for a short-term study. It was realized that to properly assess the longterm effects, long-term interdisciplinary investigations would be required. However, it was judged that interim studies would provide a more detailed and accurate environmental description of the ocean dumping grounds than had been available, and would assist in determining the lateral and vertical distribution of waste materials. Additionally, it was anticipated that these studies would identify, and possibly quantify, the environmental and ecological effects of ocean dumping, and separate and assess the effects and impact of other, land-based, pollutant sources on the coastal environment of the Bight (sources such as municipal sewer outfalls and industrial discharge pipes). To regulate ocean dumping operations, it was decided that investigations should be made to identify from off-the-shelf items, a remote-controlled sensing system that could assist regulating agencies in detecting the location and dump status of waste-disposal vessels operating in the Bight.

\section{Chronology of Events}

The following is a summary of major events related to the development of CERC-funded studies of waste disposal operations in the Bight.

1967 The Public Health Service studied the dumping grounds of the New York Harbor. Their report is dated January 1968. The study recommended that a more detailed investigation be made of the effects of sludge dumping in the disposal grounds.

23 May 67 The Director of Civil Works, OCE, in a letter to the Commissioner, then FWPCA, called his attention to the waste disposal operations of the Bight and offered to consult with FWPCA on what studies should be made on the effect on the local ecology.

27 Nov 67 The Director of Civil Works, Corps of Engineers, by letter requested the Coastal Engineering Research Center (CERC) to undertake a study of the effects of these disposal operations on water quality, water chemistry, safety, water use, ecology, fish and wildlife, conservation and recreation in the surrounding area.

21 Feb 68 The Smithsonian Institution (SI) entered into a contract with CERC agreeing to prepare a plan of study of the Bight 
disposal operations.

31 Mar 68 A plan of study was submitted to CERC by SI, entitled, "Recommendations of Studies on Waste Disposal Practices in the Coastal Waters of New York Harbor." This plan recommended a 5-year study, but also outlined a $21 / 2$ year study, recognizing that time and funds might not permit the full 5-year investigation.

2 July 68 CERC, by letter, requested the Sandy Hook Laboratory (SHL), of the National Marine Fisheries Service (NOAA) to submit a formal proposal to undertake the study, proposing the following schedule:

An interim report on total findings of the study based on field observations at least through 30 June 1969. (by 1 Nov 69)

\section{A final report. (1 Nov 70)}

7 Aug 68 CERC funded a 2-year research study proposed by SHL on the effects of waste disposal in the coastal waters of N.Y. Harbor.

$28 \mathrm{Jul} 69$ CERC made a contract with the State University of New York, Stony Brook (SUNY, SB), to undertake research to determine minor elements in selected wastes and waste deposits in the New York Harbor - Long Island Sound Area.

2 Dec 69 SI contracted with CERC to provide assistance by forming the Smithsonian Advisory Committee (SAC), a committee of experts in several disciplines, to hold meetings to review CERCfunded studies and make recommendations.

3 Dec 69 SHL delivered to CERC a progress report entitled; "Effects of Waste Disposal in the New York Bight -- Interim Report for January 1, 1970."

17 Dec 69 SAC and representatives of the Corps of Engineers visited the Marine Sciences Research Center, of SUNY, SB, and SHL to review the work being conducted at these laboratories. $(17,18$ Dec 69)

6 Feb 70 SUNY, SB submitted a progress report on the results of the studies to that date and Technical Report No. 5 of the Marine Sciences Research Center entitled, "Preliminary Analyses of Urban Wastes, New York Metropolitan Region."

20 Feb 70 SI sent to CERC its assessment of the studies to that date 
and certain recommendations for future studies.

1 Jun 70 Under contract with CERC, Woods Hole Oceanographic Institution (WHOI) began a bibliographic study on the effects of marine disposal of sewage sludge and dredge spoil in the waters of the Bight.

3 Sep 70 Letter from SHL informed CERC that final SHL report would be transmitted by 15 Feb 1971.

Sep 70 SUNY, SB submitted report to CERC, Technical Report No. 7 of the Marine Sciences Research Center, entitled, "Analyses of Dredged Wastes, F1y Ash, and Waste Chemicals - New York Metropolitan Region."

10 Dec 70 CERC, through the New York Corps of Engineers District, entered into a contract with Sperry Systems Management Division of Sperry Rand Corp. (SPERRY), funding a study of a Sea Dump Monitoring System.

29 Jan 71 WHOI submitted to CERC its final report, Technical Memorandum 1-71, entitled, "The Marine Disposal of Sewage Sludge and Dredge Spoil in the Waters of the New York Bight."

22 Feb 71 SUNY, SB submitted report to CERC, Technical Report No. 8 of the Marine Sciences Research Center, entitled, "Survey of Marine Waste Deposits - New York Metropolitan Region."

$22 \operatorname{Mar} 71$ CERC submitted to SI two completed reports requesting review by SAC. The two reports were the following:

a. "The Marine Disposal of Sewage Sludge and Dredge Spoils in the Waters of N.Y. Bight," by Woods Hole Oceanographic Institution

b. Technical Report No. 8, "Survey of Marine Waste Deposits, New York Metropolitan Region" by Marine Sciences Research Center, State University of New York, Stony Brook

$12 \mathrm{Ju} 171$ Two copies of draft SHL final report were delivered to CERC for internal review.

1 Oct 71 SPERRY submitted final report entitled, "System Study for Surveillance of Ocean Dumping Operations."

15 Feb 72 SHL in a telecon informed CERC of final completion of SHL report. Delivery of subject report promised for March, 1972. 
28 Feb 72 Representatives of SI and CERC met to discuss the SAC review of CERC-funded studies. Copies of final reports completed to this date were submitted to SAC for review and evaluation.

28 Mar 72 SHL submitted its final report, entitled, "The Effects of Waste Disposal in the New York Bight."

4 Apr 72 Copies of SHL's final report (9 sections) were sent to SAC for review and evaluation.

25 May 72 SHL submitted to CERC a summary report entitled, "The Effects of Waste Disposal in the New York Bight."

30 May 72 Copies of SHL's summary report were sent to SAC for review and evaluation.

Jul 72 SI and SAC submitted to CERC report on the review and evaluation of the CERC-funded studies.

\section{Contract Studies}

To meet the objectives outlined in the previous section and to acquire the data that would permit the assessment of the impact of ocean waste disposal in the Bight, CERC was instructed to proceed with a comprehensive study. As outlined in the chronology of events, CERC requested the SI to assist in preparing a plan. The Smithsonian Institution, under contract with CERC, provided a plan outlining the elements of study and listed the institutions qualified to undertake all or part of this interdisciplinary investigation. However, the conference of an Advisory Committee, convened by the SI in March 1968, agreed unanimously that a single short-term study could not meet all of the objectives. The consensus was that longer studies of greater scope would be required to obtain all the necessary data.

To implement partially the program recommended by SI, CERC, contracted research studies with SHL of the National Marine Fisheries, and with the Marine Sciences Research Center of SUNY, SB. Additional contracts were signed with the Woods Hole Oceanographic Institution (WHOI) and with Sperry Rand Corporation (SPERRY).

In May 1972, all of the studies funded by CERC had been concluded, and final reports were submitted to SI for review and evaluation by SAC.

Copies of the final reports were forwarded to the National Technical Information Service (NTIS) Department of Commerce for public dissemination. 
Copies of these reports may be purchased from:

National Technical Information Service
ATTN: Operations Division
5285 Port Royal Road
Springfield, Virginia 22151

The primary objectives of each research contract are given in the following sections under the respective headings along with bibliographic entries and a list of references.

a. Sandy Hook Laboratory Study. The contract with Sandy Hook Laboratory (SHL) of the National Marine Fisheries provided for interdisciplinary ecological studies of the Bight dumping grounds. The 2-year investigation by SHL included studies of benthic meiofauna and macrofauna distribution in the Bight, benthic microbiology, pathological effects of wastes on larger benthic crustaceans, analysis of basic chemical variables affecting benthic invertebrates, zooplankton and finfish. To support the ecological studies, chemical and hydrographic studies were also conducted. The results of the studies are outlined in the following reports:

Sandy Hook Laboratory, 1971, "The Effects of Waste Disposal in the New York Bight," National Marine Fisheries Service, Middle Atlantic Coastal Fisheries Center, Tech. Rept., 9 Vol, 749 pp., N.T.I.S. Acquisition numbers AD 730531 through AD 739539.

Sandy Hook Laboratory, 1972, "The Effects of Waste Disposal in the New York Bight," Summary Final Report (Middle Atlantic Coastal Fisheries Center) National Marine Fisheries Service, $70 \mathrm{pp}$, N.T.I.S. Acquisition number, AD 743936.

b. State University of New York, Stony Brook Study (SUNY, SB). SUNY, SB under contract with CERC undertook chemical studies of waste deposits to determine elements in selected areas of the Bight. These studies are outlined in the following three reports:

GROSS, M. G., "Preliminary Analyses of Urban Wastes, New York, Metropolitan Region," Marine Sciences Research Center, State University of N. Y., Stony Brook, Tech. Rept. 5, 35 pp. (NTIS Acquisition Number AD 746 959).

GROSS, M. G., 1970, "Analysis of Dredged Wastes, Fly Ash, and Waste Chemicals - N.Y. Metropolitan Region," Marine Sciences Research Center, State University of N. Y., Stony Brook, Tech. Rept. 7, 33 pp., Acquisition number AD 734337.

GROSS, M. G., et al, 1971, "Survey of Marine Waste Deposits, N.Y. Metropolitan Region," Marine Sciences Research Center, State University of N.Y., Stony Brook, Tech. Rept. 8, 72 pp., Acquisition number AD 723431. 
c. Woods Hole Oceanographic Institution. The WHOI contract provided for a literature search and review of oceanographic knowledge and waste disposal practices for an area extending from Cape Cod to Cape Hatteras. The results are outlined in the following report:

HORNE, R. A., et al, 1971, "The Marine Disposal of Sewage Sludge and Dredge Spoil in the Waters of the N. Y. Bight," Woods Hole Oceanographic Inst., Woods Hole, Mass., Tech. Memo 1-71, 37 pp., NTIS Acquisition number AD 722791.

d. Sperry Rand Corporation Study. The Sperry Rand Corporation contract provided for conduct of a feasibility study for a system that could provide remote surveillance of ocean dumping activities in the Bight. The results of this investigation are in a report:

Sperry Systems Management Division, Sperry Rand Corporation, "Ocean Waste Dumping Operations Monitoring," 1971, NTIS Acquisition number AD 735378.

e. Smithsonian Institution Study. The first contract signed with SI provided for initial planning of the CERC-funded studies; a second contract provided for the establishment of a Scientific Advisory Committee (SAC), whose role was to advise, review and evaluate all the studies in the Bight and recommend a future course of action.

(1) Smithsonian Advisory Committee (SAC). SAC, a committee of experts in several scientific disciplines, was selected by personnel of the Oceanography and Limnology Program of the Smithsonian Institution. Members of the committee at the conclusion of the studies and who prepared the final SAC report, were as follows:

*Dr. Martin A. Buzas, Smithsonian Institution

${ }^{*}$ Dr. James H. Carpenter, Johns Hopkins and National Science Foundation

*Dr. Bostwick H. Ketchum, Woods Hole Oceanographic Institution

*Dr. J. Laurence McHugh, State University of New York at Stony Brook

*Dr. Virgil J. Norton, University of Rhode Is1and

*Dr. Donald J. O'Connor, Manhattan College

Dr. Joseph L. Simon, University of South Florida

Dr. David K. Young, Smithsonian Institution (Chai rman of Committee)

Dr. Robert P. Higgins, Director of the Oceanography and Limnology Program of the Smithsonian Institution retained overal1 administration of SAC.

Members of the committee whose names are designated by an asterisk * are original members of the committee who participated in the site visits of the research laboratories responsible for the investigations, and who reviewed the field work of these laboratories on 17 and 18 December 1969. 
(2) Review, Evaluations and Recommendations. The SAC was asked to review and evaluate the reports resulting from the CERC-funded research in terms of their scientific content. The SAC was also asked to assess the effects of waste disposal on the environment of the Bight, to recommend further research, and to suggest changes in the present disposal operations. For the complete SAC review and evaluation of subject reports, the reader is referred to the comprehensive SAC report:

Smithsonian Institution, Oceanography and Limnology Program, Office of Environmental Sciences, 1972, Smithsonian Advisory Comnittee Report on Studies of the Effects of Waste Disposal in the New York Bight, NTIS Acquisition number AD 746960

Reference to the SAC review and evaluation is made throughout this report. Because the WHOI study is primarily a literature search of information regarding the New York Bight, and since the SPERRY study on the surveil1ance system was considered outside the area of the SAC expertise, the committee concentrated its review, comments and evaluation on those reports of original research by SUNY - SB and SHL.

On the basis of these final reports the SAC general comments and evaluations are summarized as follows:

Although the studies supported by the CERC have produced valuable data regarding ocean disposal of acid-iron wastes, sewage sludge and dredge spoil in the New York Bight, data presention does not allow evaluation of the ecologic effects (detrimental, beneficial or neutral) of the ocean dumping operations. The large quantities and toxic qualities of the wastes being dumped in the Bight suggest that the impact on the marine environment may be substantial.

The chemical and physical characterization of the constituents in waste materials as conducted by SUNY - SB has produced valuable data, and has provided direction for future investigation.

Some data has been collected by the SHL which is qualitatively useful. Insufficient definition, however, of sampling characteristics and apparent lack of adequate planning in the collection of data, have not permitted the statistical treatment necessary for the evaluation and quantification of environmental characteristics and proper assessment of ecologic effects.

The possibility of pathogenic damage to finfish and shellfish resulting from the disposal of waste materials in the Bight, brought to light by the SHL study, carries important implications requiring additional extensive investigations. 
At least 98 estuarine and coastal ocean areas in the United States and five in Canada are used for the disposal of dredge spoils (Gross, 1971). The total annual volume of dredge spoils disposed of in the marine environment, is estimated at $7.3 \times 10^{7}$ tons per year and accounts for about 80 percent by weight of all wastes being dumped in the ocean (Council on Environmental Quality, 1970). The remaining 20 percent is primarily treated and untreated sewage. Gross indicates that along the U. S. Atlantic coast, there are 59 active waste disposal sites, four more are located in Canadian waters, 20 sites are actively used along the U. S. Pacific coast, in addition to one site in the Canadian Strait of Georgia. Puerto Rico and Alaska each have two active sites. About 95 waste disposal sites are in the Great Lakes. These figures do not include a great number of ocean outfalls that discharge municipal effluents and industrial wastes into the waters of the country.

On $1 y$ in the last few years has ocean waste disposal become a problem of national concern. Literature review indicates that there have been few comprehensive studies concerned with the effects of waste disposal on offshore marine environments. It is difficult to correlate the results of different studies since the hydrography, water depth, sediment characteristics, and biota are often markedly different at each study site. To allow the reader to assess similarities and differences of the results of other studies with those of the Bight studies, a summary of other known investigations is given.

\section{Rhode Island Sound}

Between December 1967 and September 1970, spoils from the Providence Harbor dredging totaling 9 million cubic yards, were deposited outside Narragansett Bay in Rhode Island Sound, 4 miles south of Newport, in waters 96 to 100 feet deep. The spoil consisted of silts and compacted sands.

The disposal site was studied by the University of Rhode Island (Saila et al, 1971) to determine physical changes in the dumping area and the effect of spoil on marine organisms, and to predict the nature of recovery of the area after dumping ceased. It was found that the spoil centered in conical formations 16 to 18 feet high and $1 \mathrm{mile}$ in diameter, but patches of spoil were found a mile away from the dump site. The study concluded that the direct effects of dumping on marine animals appeared to be limited. Most mollusk species could reach the sediment surface after shallow burial; less mobile forms were buried. High turbidity values caused no observed increase in mortality.

Fish and lobsters could withstand the high concentrations of suspended sediments for short periods. Lobstering was the least affected fishery in the area; good catches were made on the perimeter of the dump. Ocean quahogs were killed by burial near the center of the area, but not on the perimeter. 
The dominant species in the area, a tube-building amphipod, was found in great density over the test area. The recolonization by these amphipods and worms indicated that the spoil surfaces did not contain large amounts of toxic materials. Species diversity varied spatially. Dissolved oxygen was lacking in the pore water of the spoil sediments, but no anoxic conditions developed in the overlying water. Furthermore, hydrocarbons and heavy metals did not appear in high concentrations in the dumping grounds.

The study recommended that the dumping area is suitable for further disposal of relatively cohesive and unpolluted material, but that additional investigations should be made of the ocean bottom currents, of the sediment characteristics, and of the rehabilitation and recolonization of the spoil area by benthic organisms.

\section{Delaware Bay}

Since 1961, the City of Philadelphia has disposed digested sludge 11.5 nautical miles $(21.3 \mathrm{~km})$ off Cape May, N.J. and Cape Henlopen outside Delaware Bay. The dumping grounds are 60 feet deep, and cover a rectangular area 1 mile by 2 miles. (Guarino, 1967; Civil Engineering, 1968; Baxter, 1959; City of Philadelphia, 1968). In January 1971, the City contracted research studies with the Franklin Institute Laboratories and the Jefferson Medical College Laboratories: (a) to provide more detailed environmental description of the dumping grounds; (b) to determine the environmental and ecological effects of the dumping operations; and (c) to determine the existence of pathogenic micro-organisms in the area.

The interim results were summarized by Baxter, et al, (1971) as:

a. Sediment samples taken from the Center of the disposal site and the immediate vicinity consisted of clean sand along with gravel and shell fragments.

b. In all sediment samples taken in and around the disposal area, no black sludge or samples emitting hydrogen sulfide were found.

c. At the center of the sludge disposal area, starfish, sand dollars, hermit crabs, and snails were found in good health. A good variation of species was observed at all stations.

d. Fish specimens collected at the disposal site included winter flounder, mackeral, stargazer, long horn sculpin, and spiny dogfish.

e. Dissolved oxygen measurements of bottom, middle and surface waters at various points within and around the site showed no signs of oxygen depletion or sag.

f. Coliform levels in all bottom, mid and surface waters were zero.

g. There were no indications of significant concentrations of heavy metals in surf clams and other macrofauna collected in the area. 
h. Low recovery rates of surface and bottom drifters suggested the absence of strong, shore-directed, currents.

The general conclusion of the interim study was that the sewer sludge is assimilated into the ocean environment as quickly as it is put there, and that no adverse effects on the ocean environment have occurred. It should be emphasized that the quantity of sludge disposed of by Philadelphia in this area, is much less than that disposed of in the New York Bight, and that the practice is rather recent, dating back only to 1961. Furthermore, apparent rapid assimilation of the sludge may be due to the rapid dispersion by surface currents and the low sett1ing rate of the sludge particles. Laboratory tests of the physical characteristics of Philadelphia's sewage sludge (Kupferman and Murphy, 1973) showed such slow settling rates. Also, when mixed with sea water, the sludge appeared to "fluff out," 1 milliliter of undiluted sludge bulking up to almost 2 milliliter at the bottom of the settling tube.

\section{Chesapeake Bay}

The gross physical and biological effects of shallow-water disposal of dredge material in the upper Chesapeake Bay were studied by the Chesapeake Biological Laboratory of the University of Maryland (Cronin, et al, 1967). The comprehensive study included a description of the natural loads of suspended sediments in the water, and descriptions of zooplankton, phytoplankton, benthic organisms, fish and larvae populations in the Bay. Furthermore, the direct effects of disposal on all of these characteristics and populations, were assessed.

It was established that study area was highly productive of animals and plants, that it was intensively used by a variety of useful fish and invertebrates, and therefore was important as a spawning and nursery ground. Although field studies of the type conducted are not considered adequate to evaluate critically the effects of heavy sediment loads, they do provide qualitative data about the presence or absence of massive damage.

The studies also observed and concluded that: (a) the spoils spread over an area which was at least five times larger than the designated disposal area, and that turbidity increased over a 2-square mile area. However, the turbidity was within the natural range of turbidities found in this area throughout the year; (b) a high concentration of nutrients was in the area; total phosphate and nitrogen were increased by factors of 50 and 1,000 respectively; (c) no gross effect was observed on the microscopic plants and animals in the water, nor on the eggs and larvae of fish, nor on adult fish held in cages near the discharge point or caught near the area; and (d) significant loss of bottom animals occurred as a result of burial, but certain species began repopulation soon after deposition, and 18 months 1 ater, the numbers had returned to previous levels.

The study emphasized the future need for suitable laboratory studies 
based on the geological, hydrographic, and biological data obtained in the field, and the need for accurate monitoring before and after the disposal of spoils.

Another study by the Virginia Institute of Marine Sciences assessed the effects of spoil disposal for two dredge operations in the lower Chesapeake Bay area (Harrison, W., 1967). In one operation 1.26 million cubic yards of spoil were dumped in a rectangular area 0.5 by 1.0 nautical $\mathrm{mi}$, in depths of 75 to 96 feet.

Disposal of spoils in this area appeared to have only a transitory effect on infauna and epifauna populations. Recolonization in areas of dredging and disposal was rapid due to the active migration of the animals and to the hydrodynamic distribution of juvenile and larval stages.

An extension of the same study monitored the possible spoil buildup on an oyster ground in the York River estuary, in response to anticipated spoil deposition from an outfall located 0.8 to $2.0 \mathrm{miles}$ in a downestuary direction. It was concluded that the general trend in sedimentation along the perimeter of the oyster grounds before, during, and after the dredging, was one of slight erosion. Dredging and spoil disposal had no observable effect on the character of the river bottom or the natural animal population within the study area. Mortality of the oysters was not above normal.

A study of the Rappahannock Shoal and spoil disposal area (Brehmer, et al, 1967) indicated a greater species diversity and number of organisms in the spoil areas than in the ooze-covered natural substrate in the deeper parts of Chesapeake Bay. Infaunal organisms with the exception of certain worms, did not recolonize the dredged channel, and it was concluded that faunal groups comparable to those of adjacent shoals would not be supported. However, it was speculated that in time spoil areas would eventually reestablish their population densities.

\section{Southeast Florida}

Untreated sewage along the coast of southeast Florida is disposed of by ocean outfa11s. The discharge points of these outfalls vary from a depth of 16 feet, 6,400 feet offshore, to a depth of 90 feet, 10,000 feet offshore. Riviera Beach, Palm Beach, Lake Worth, Delray Beach, Boca Raton, Pompano Beach, Hollywood, North Miami, Miami Beach, and Miami are the coastal communities using ocean outfalls.

The biological, chemical and physical properties of the coastal waters off Pompano, Boca Raton, and Delray, were investigated over a 3-year period by a study funded by the Environmental Protection Agency (Florida Ocean Sciences Institute, 1971). The biological investigation included surveys of the microscopic benthic communities and microbiotic organisms of the sediment-water interface and of the free drifting plankton. This investigation concluded that the number of planktonic 
organisms were consistently low in the coastal waters near the presently operating Pompano and Delray outfalls. No noticeable fertilization effects were found, and planktonic blooms with numbers greater than 500 per milliliter were rare. A pile of sand and blackened organic material, about 3 feet high, 50 feet long and 30 feet wide was observed beneath the outfall. Only one species of pollution resistant worms survived here. In the outer periphery of this pile, extending 100 feet north-south and 50 feet east-west a limited number of species were observed.

Hydrographic investigations showed that coastal circulation and exchange processes were dominated by the Florida current. This was attributed to the extreme narrowness of the Continental Shelf in this area ( 1 to 1.5 nautical miles). Large fluctuations in the speed and direction of the meandering western edge of the Florida current, trave1ing northward through this coastal area, affected local circulation. Resultant coastal currents were found to be flowing in a north-south direction, with north currents predominating. Current reversals were found to be associated with the cyclonic eddies of the Florida current. These eddies appeared to behave as the major flushing mechanism masking the effects of diurnal and semidiumal tidal current fluctuations. The residence time of the coastal water was estimated to be about 1 week.

The spatial and temporal concentrations of sewage deposits were determined by fluorometry and dye-tracing techniques. Predominance of onshore winds were found to create surface sewage plumes, containing high concentrations of coliform bacteria.

\section{Southern California}

a. Santa Monica Bay. Domestic and industrial waste waters from the City of Los Angeles and 13 other cities are dumped in Santa Monica Bay. These wastes receive different degrees of treatment by the Hyperion Treatment P1ant and are discharged into the Bay by pipeline outfalls. The 1-mile effluent outfall has operated since 1949, the 7 -mile digested sludge outfall since September 1957, and the 5-mile outfall was placed in service early in 1960. About 4,000 tons of solids per day are discharged in the area.

A study of sedimentation and dilution of digested sludge in Santa Monica (Brooks, 1957) concluded that sludge accumulation rates should average 2-3 inches per year within a 500-foot radius decreasing to 0.25 inch per year at a 2 -mile radius from the outfall, assuming a constant current of 0.2 knot with equal frequencies in all directions. These rates of accumulation were considered unobjectionable based on 1956 standards.

To assess the effects of the various discharges from the Hyperion Treatment Plant since 1954, the City of Los Angeles has conducted and supported extensive studies of the Bay. The results of observations made through December 1959 have been summarized in papers by Hume et al, (1962), by North (1962), and more recently by Hume and Graber (1966). 
These studies determined that effluents and digested sludge discharges from the Hyperion Plant include significant amounts of organic and mineral constituents. These amounts cause measurable effects in the various animal and plant populations of the receiving waters and bottom sediments. The observed total effect of both the effluent discharge at 50 feet and the digested sludge at 320 feet, is to increase the standing crop of plankton and animals in the Bay. Maximum populations, however, were found at some distance from the outfalls. Fish were obtained from every station on every trawl. Bio-assays showed no toxic effects on test fish caught outside the immediate vicinities of the discharges. The deposits from the sludge outfall were found to be stabilized by several species of marine worms which attained densities of as many as 200,000 per square mile.

In addition, between 1958 and 1963, the California Department of Fish and Game in cooperation with the City of Los Angeles, Bureau of Sanitation, in order to determine the effects of waste disposal on fish populations, conducted bottom traw1 studies in Santa Monica Bay (Carlisle, 1969). The data indicated local changes in the vicinity of the waste outfalls. It was impossible to demonstrate that fluctuations in the abundance of species were the result of waste discharges in the study area and not due to natural causes. Certain fish species avoided areas of high waste concentration; other species were attracted. However, it was suggested that species diversity in the discharge areas may be lower than in waste-free areas.

Another study (Carlson and Zichefooze, 1965) indicated that California's giant kelp (Microcystis pyrifera) is being adversely affected by increases in sea urchin populations apparently nurtured by waste disposal. This kelp once constituted a prominent and probably dominant ecological factor of the coastal environment. Between 1945 and 1965 the kelp beds became substantially diminished near the sewage outfalls from Los Angeles and Santa Barbara.

A study of the effects of discharged wastes on kelp was published by the California State Water Quality Control Board (1964). This study concluded that turbidity of the water due to outfall discharges may be a significant factor. No direct relationship, however, was established between particulate wastes as a major factor of turbidity and kelp production. The reduction in the extent of kelp beds, and the decrease of coastal fisheries in this area may be coincidental, and cannot be attributed exclusively to waste discharges.

Another study sponsored by the Sport Fishing Institute (SFI), a predecessor component of EPA, could not associate turbidity with the ecology of the giant kelp. The evidence related reduction of kelp beds to the addition of nutrients from sewage (such as free amino acids) rather than to possible effects of particulate matter. It was believed that these nutrients are extensively absorbed from the sea water by urchins, which are the natural grazers of kelp, resulting in an increase and dominance of urchin populations. A series of warm-water years in 
the midfifties and an abundance of sea urchins, may be responsible for the kelp reduction. The kelp beds of California, however, are not obliterated by any means. The kelp industry harvests annually 100,000 to 120,000 tons of this important resource.

The general conclusion of all studies in Santa Monica Bay is that in the 20 years of continuous discharges by the Hyperion Plant, with the exception of the kelp, remarkably little damage has been done to the marine environment.

b. San Diego. The rate of accumulation of digested sludge discharged by an ocean outfall located 2 miles off the San Diego shore in 200 feet of water, has been reported by Orlob (1965).

In this study, the sludge accumulation rate was estimated at 0.1 inch per year near the outfall, with 40 percent of the solids settling at such slow rates that their accumulation within a radius of 5 miles could be considered neglible. Grease and floatables were identified as a potential problem, but were not defined quantitatively. The study did not consider the effects or destination of the solids which are carried away from the discharge area.

\section{San Francisco Bay}

About 8 million cubic yards of material is dredged annually from San Francisco Bay. Most of the dredge spoil is disposed of outside the Bay on the San Francisco Bar, but part of it has been dumped inside the Bay near Alcatraz Island.

To determine the effects of dredging and spoil disposal on fish and wildlife environment within certain areas of San Francisco and. San Pablo Bays, the Corps of Engineers funded a study by the U. S. Fish and WildIife Service (National Marine Fisheries Service). Due to rapidly fluctuating environmental variables, this study did not determine any apparent adverse effects in the deep channel areas (U. S. Fish and Wildlife, 1970). In the other areas, however, the study indicated a significant reduction of numbers and species composition of benthic organisms and demersal fish. Although certain species reestablished themselves in the affected areas within a short time, the species diversity index did not return to its previous level during the study period. The study did not show that turbidity had a major effect on marine life. Furthermore, turbidity within the Bay, at least in the shallow areas, appears to be a naturally occurring phenomenon. According to the Civil Engineering Department of the University of California at Davis (Krone, 1972, informal communication) which has conducted studies of the waterways circulation system in San Francisco Bay for more than a decade, present and past dredging activities are in significant in terms of total distribution of sediment being put to circulation by natural processes. According to these studies, the amount of bottom sediment agitated into suspension in 5 -foot depths by wave action of 10-knot winds blowing from less than 5 square miles of the Bay, exceeds the 
input of all dredging in an equal time period.

Quantitative correlations of species diversity depression with waste water toxicity have been determined by previous studies in the San Francisco Bay area (Kaiser Engineers Consortium, 1969, Allan Hancock Foundation, 1965). These studies found a linear relationship between the concentration of toxicity in the Bay waters and the reduction in benthic species diversity.

More recently, a study was made by the San Francisco District of the Corps of Engineers (U. S. Army Engineer District, San Francisco, 1971), for the purpose of determining the effects of disposal of dredge materials on the marine environment, developing dredging procedures, and assessing disposal sites. The development of alternatives that would mitigate possible adverse effects or augment marine resources in the affected area was considered. The preliminary study was confined to dredging spoils from the Main Ship Channel, the first leg of the John F. Baldwin and Stockton Ship Channel. Studies of the remaining parts of the John F. Baldwin Ship Channe1, Oakland Harbor, Richmond Harbor, Redwood Harbor and other areas, have not yet been reported. The study program included sampling, testing, and analyzing the physical, biological, and chemical characteristics of the Main Ship Channel and those of the disposal site on the San Francisco Bar, south of the Main Channel, outside the Bay.

Based on the completed parts of the studies it was concluded that: (a) the dredge spoil material from the Main Ship Channel leading into the San Francisco Bay is not considered polluted by present EPA criteria, with the exception of zinc which in two out of five instances exceeded EPA limits; (b) insufficient sampling of water quality data could not permit complete analysis of the impact of dredging and disposal operations in the area, but preliminary data indicated water quality at the test site to be within limits established by the California Regional Water Quality Control Board; (c) benthic animals of the borrowing types, which were observed on the Bar, appeared to be capable of surviving under some sediment accumulation; (d) dispersion by strong currents of dredge material dumped waters over the Bar does not appear to significantly alter bottom conditions or result in excessive deposition of sediments. In view of ever-changing, dynamic bottom conditions and the types of organisms inhabiting the Bar, it was concluded that bottom organisms would not likely suffer any harmful burial effects as a result of spoil discharge on the Bar; and finally, (e) because of the active circulation characteristics, unpolluted material disposed on the Bar would enter the littoral regime, and might contribute beneficially to the nourishment of eroding coastal beaches.

Since July 1970, two additional studies of the problem of dredging and spoil disposal were funded by the Corps of Engineers and were made by the Environmental Protection Agency and the U. S. Geological Survey. The EPA study includes environmental investigations on the effects of channel opening in the periodically polluted section of San Joaquin River 
navigation channe1, downstream from Stockton.

The USGS study is a survey of freshwater aquifers from Carquinez Strait, through Suisun Bay to the confluence of the Sacramento and San Joaquin River, at Sherman Island. The results of these two studies are pending.

A similar survey of San Francisco and San Pablo Bays is being conducted jointly by the USGS and the Department of Housing and Urban Development. In addition, the San Francisco District of the Corps of Engineers plans to monitor freshwater aquifers in the area for potential salinity intrusion during and after dredging operations.

\section{Puget Sound}

Studies of the effects and fates of digested sludge disposed through outfalls in the Puget Sound area, have been performed by a number of investigators. Brooks, et al (1965) studied outfall designs and gave predictions for sludge accumulation. An earlier study by Sylvester (1962) pointed out potential problems arising from the increase in the nutrient content of the water, the sludge accumulation, the floatable materials, and the effects of such factors on the marine ecology. Servizi, et al (1969) studied the effects on sockeye and pink salmon of dredging and disposal of sediments from Bellingham Harbor, known to contain paper mill pulp fibers and hydrogen sulfide. They recommended that before dumping such sediments in open waters, four factors should be considered: (a) turbidity created during disposal; (b) the biochemical oxygen demand of the sediment; (c) the release of toxic hydrogen sulfide during disposal; and (d) generation of hydrogen sulfide by the sediments after they settled.

Consideration of possible dredge spoils disposal sites in Puget Sound resulted in a study by the Department of Fisheries, State of Washington of the bottom sediments of Olympia Harbor (Westley, et al, 1972). The sediments of olympia Harbor have a volatile solids content that exceeds the 6 percent standard recently set by the Environmental Protection Agency as the limit for marine disposal (EPA, 1972). The study evaluated the status of the sediments and their possible toxic effects.

Chemical analyses of the bottom sediments of Olympia Harbor indicated considerable variation between stations in this harbor and the unpolluted control station on Oro Bay. The volatile solids, biological oxygen demand, (BOD), and sulfides of Olympia Harbor appeared to be in concentrations about $1 / 3$ of the way between presumably unpolluted areas and those of areas considered to be highly noxious.

Bio-assays conducted to detect possible direct toxicity to phytoplankton, showed no such effect, although settling of silt was observed to entrap phytoplankton organisms. A major stimulating effect on the photosynthetic rate of phytoplankton was observed with increased nutrient concentrations in the bottom sediments. During the course of the 
phytoplankton bio-assay, light levels were kept adequate to enable photosynthesis, and may have been partly responsible for such stimulation. In nature, however, reduction of light by turbidity would be expected to depress photosynthesis.

Bio-assays carried out with juvenile pink salmon did not show direct toxicity. Some observed disorientation was attributed to turbidity. Samples with solids concentrations up to 5 percent did not produce significant mortality after the 48 -hour period of the bio-assay, or during the subsequent day of observation.

Based on the results of the chemical and fish bio-assays, the study concluded that bottom sediments of 0lympia Harbor appear to be moderate to low in toxicity, and much less than those of Bellingham Harbor.

\section{Great Lakes}

Studies of the effects of dredging on water quality in the Great Lakes concluded that lack of uniform procedures for sampling and analysis, make such investigations difficult (U. S. Army Engineer District, Buffalo, 1969). The problem is further compounded by the variation in the degree of pollution of sediments at different harbors.

The studies concluded that dredging has little influence on water quality, especially where the water is already polluted. At harbors such as Rouge River and in Great Sodus Bay, some temporary adverse effects were observed. At other harbors, such as Buffalo and Cleveland, dredging appeared to have a beneficial effect because of the removal of polluted materials. The studies, however, were inconclusive as to the fate and effects of dredge spoils following disposal in the Lake.

The effects of spoil disposal on the water quality and on the flora and fauna were equally in doubt. Bio-assay investigations with dredge spoil by the University of Wisconsin, suggested a relationship between the chemical composition of these sediments and their toxicity or algalgrowth promoting potentials. Based on these bio-assays, the reviewing Board of Consultants concluded that the long-term impact of open-water disposal of dredge spoils on eutrophication is not known, because water quality criteria are not well established. The Board acknowledged that in-lake disposal of heavily polluted dredge spoils is undesirable because of its long-term adverse effects on the marine environment and ecology of the Great Lakes.

\section{Other Countries}

a. Scotland and England. Sewage sludge from the city of Glasgow and adjoining areas has been dumped in the Firth of Clyde for years at an average rate of 1 million tons per year.

Preliminary investigations (Mackay and Topping, 1970) covered the composition of the sludge, the hydrography of the dumping area, and 
some of the chemical characteristics of the sediments. More recently, detailed chemical and biological surveys of the area were undertaken (Mackay, et al, 1972).

Since summer 1971, increased sampling over a wide area has provided a clearer understanding of the factors controlling the distribution and dispersion of trace substances and a determination of their effect on the fauna of the area. Organochlorine pesticides and polychlorinated biphenyls, known to occur in sewage sludge, are presently being studied by the University of Glasgow.

As in the New York Bight, completed investigations of the dumping grounds of the Firth of Clyde found a strong association of heavy metals with organically rich sediments. Also, animals taken near the center of the dumping area were found to contain much higher levels of trace elements than those taken further away. No sampling station was devoid of fauna, though species composition varied considerably. For example, a change was observed, from a molluskan/echinoderm community further from the center of the dump to a polychaete community near the center.

A study of the effects of sludge dumping in the outer Thames Estuary, England (Shelton, 1971), determined that oxygen content of the bottom waters was near saturation. Lower oxygen concentrations were observed in surface waters. No apparent changes in benthic infaunal populations were observed.

b. Turkey. Large quantities of untreated sewage and industrial wastes are discharged annually into the Bosphorus, Sea of Marmara and Dardanelles from Istanbul and other municipalities in Turkey.

This area was studied by Woodward-Envicon, Inc., an environmental consulting firm of San Diego, California, under the sponsorship of the Turkish government, the City of Istanbul and the World Health Organization (Marine Pollution Bulletin, 1972).

The study determined that such discharges contributed 200-1,000 milligrams per liter suspended solids, had a biological oxygen demand of 150-400 milligrams per liter, resulted in $\mathrm{pH}$ of $7.1-8.4$, and contained from $5 \times 10^{5}$ to $5 \times 10^{8}$ coliform bacteria per 100 milliliters. Analyses of samples taken from 22 bathing beaches by the Istanbul Public Health Institute showed that seven of the beaches are highly polluted, and that there is a high risk of typhoid, hepatitis, bacillary dysentery and gastroenteritis from such high concentrations of bacteria. 


\section{Bottom and Subbottom Characteristics}

a. Geomorphology. New York Bight is the geographic name given to the re-entrant Atlantic coast and Continental Shelf region extending from Cape May, New Jersey, north and east to Montauk, Long Island (Figure 2). The coastline is characterized by sandy beaches with numerous estuaries which include Little Egg Inlet, Barnegat Inlet, Lower and Upper New York Bay, East Rockaway Inlet, Fire Island Inlet, Moriches Inlet and Shinnecock Inlet. Water depths generally exceed 100 feet within about 50 miles offshore.

The Inner New York Bight covers about 250 square miles (Figure 3 ) and was formed by the drowning of the lower Hudson and Raritan river valleys by the post glacial rise of sea level. Lower Bay, the largest part of New York York Harbor, is separated from the open ocean by Sandy Hook and Rockaway Point. The lower parts of the Hudson and Raritan Rivers, their tributaries (East River, Arthur Ki11, Kill Van Ku11, Harlem River), Newark Bay, and Upper Bay are called the Inner Harbor. The part south of Staten Island lying between the Narrows and the harbor entrance is considered the Outer Harbor.

The Continental Shelf, seaward of New York Harbor is a gently sloping plain, 110 miles wide, marked by numerous submerged small relief ridges and troughs which resemble remnant barrier islands and associated lagoons dissected by subaerial glacially fed streams. (McKinney and Friedman, 1970). Much of the present shelf morphology evolved during the past 15,000 years as the climate has moderated and sea level risen. The Hudson Channel is a relict submarine channel that extends south from the entrance of the Harbor continuously across the Shelf, to connect with the head of Hudson Canyon at the Shelf edge.

The surface morphology of the inner Continental Shelf in the ocean dumping grounds of the N.Y. Bight has been significantly altered over the past 85-90 years by anthropogenic deposition. Comparison of Figures 3 and 4 clearly shows that the Hudson Channel immediately east of Sandy Hook has been modified as well as the Diamond Hill area about 2 miles northeast. Historical records indicate that those areas have received various types of disposed materials since at least 1885 . Figure 5 shows the limits of significant contour differences between the 1845 survey (Figure 4) and the most recent chart (Figure 3).

b. Geologic History and Stratigraphy. CERC, as part of its Inner Continental Shelf Study Program (ICONS) has collected 445 miles of high resolution geophysical reflection records from the shallow shelf area in the Inner Bight (Fig. 6). In addition, 61 pneumatic vibratory piston cores averaging 10 -feet long of recovered material and 4 -inches in diameter and have been obtained (Williams and Duane, in press). Some cores were taken in the individual dump grounds, and showed small amounts of apparent spoil. Also, borings, to depths in excess of 100 feet, were 


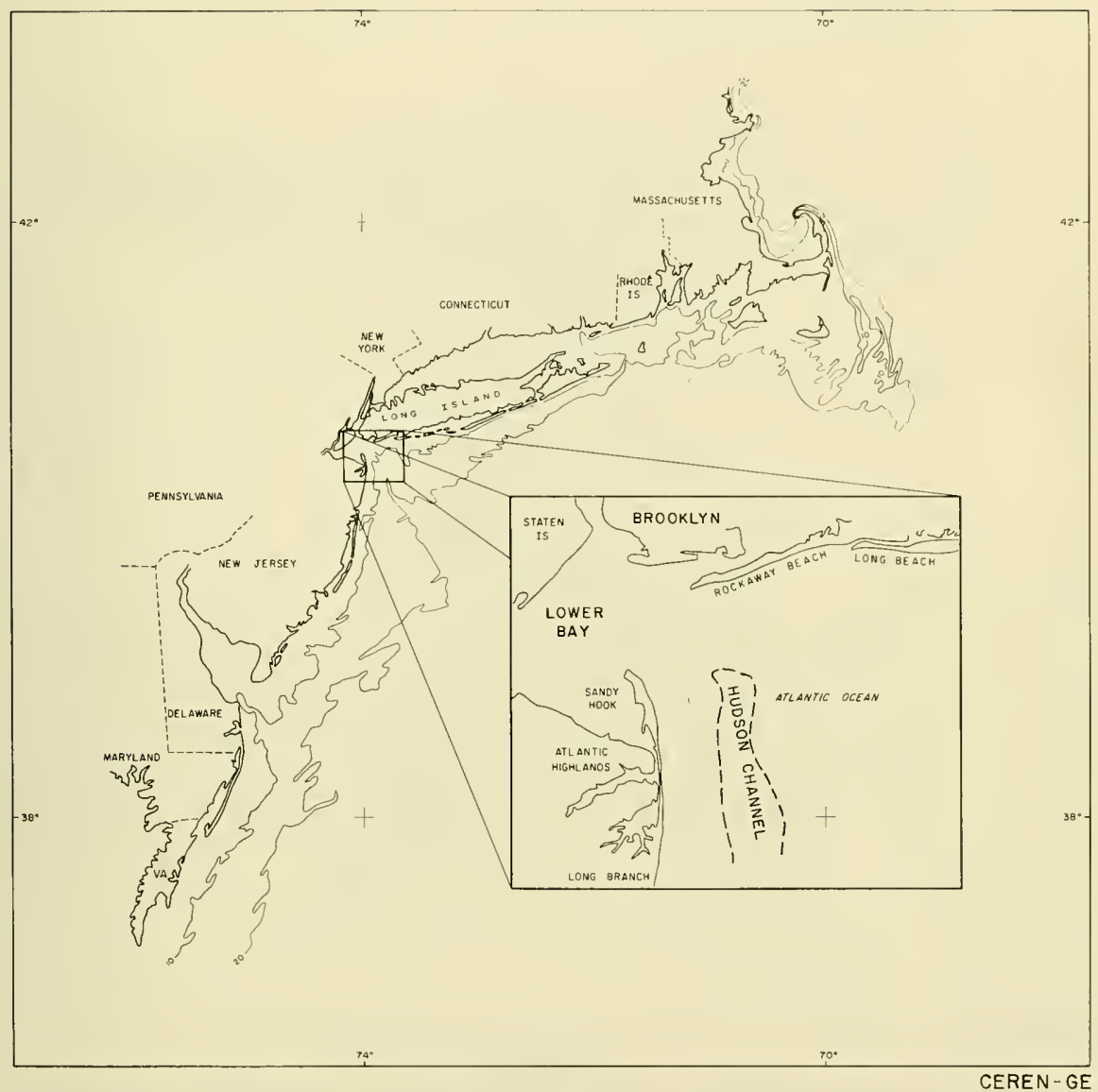

Figure 2. Northeastern Coast of United States Including the N. Y. Bight (Blowup of area of interest) (After Williams and Duane, in press) 


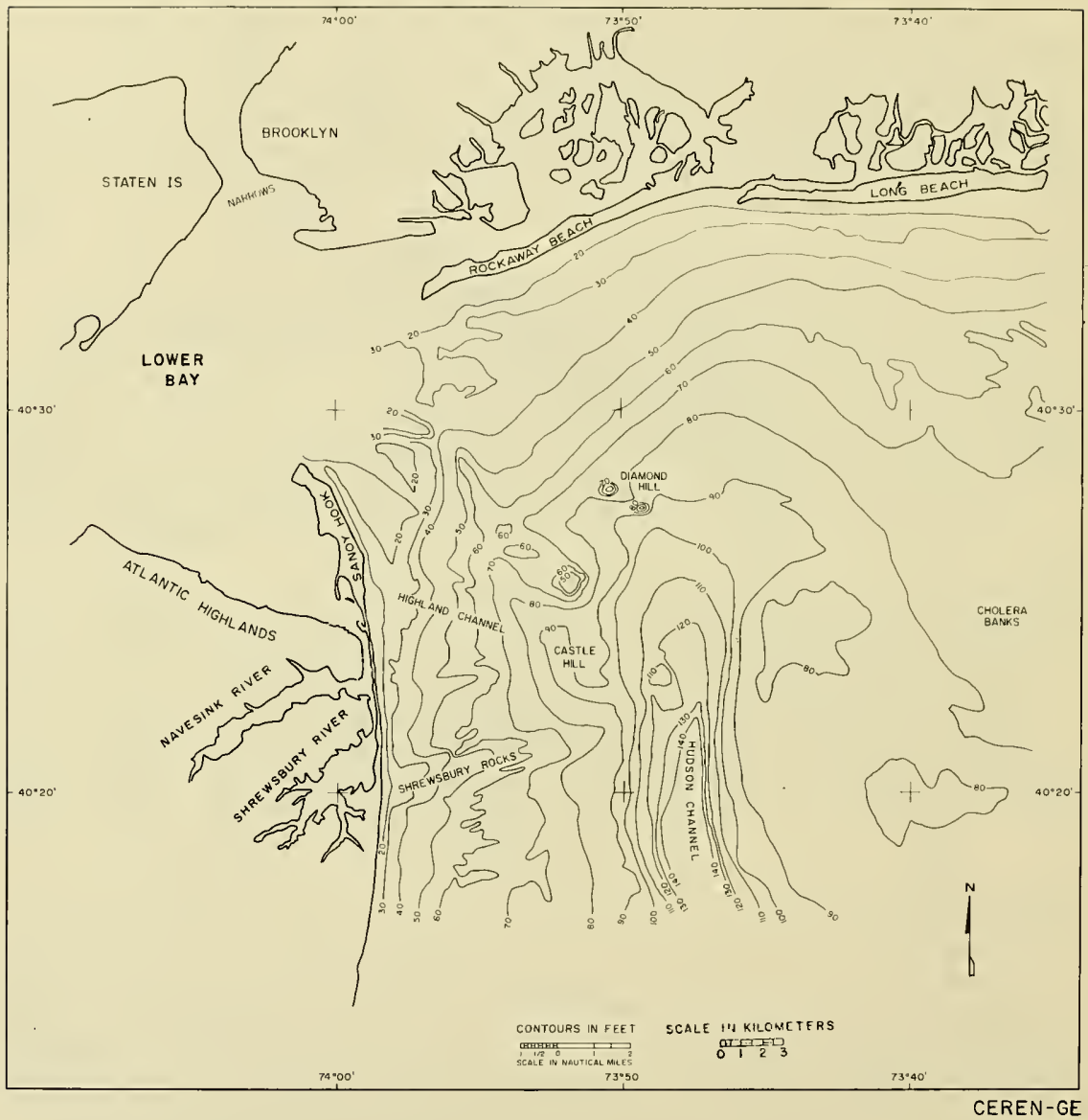

Figure 3. Recent Bathymetry of the Continental Shelf Outside New York Harbor (After Williams and Duane, in press) 


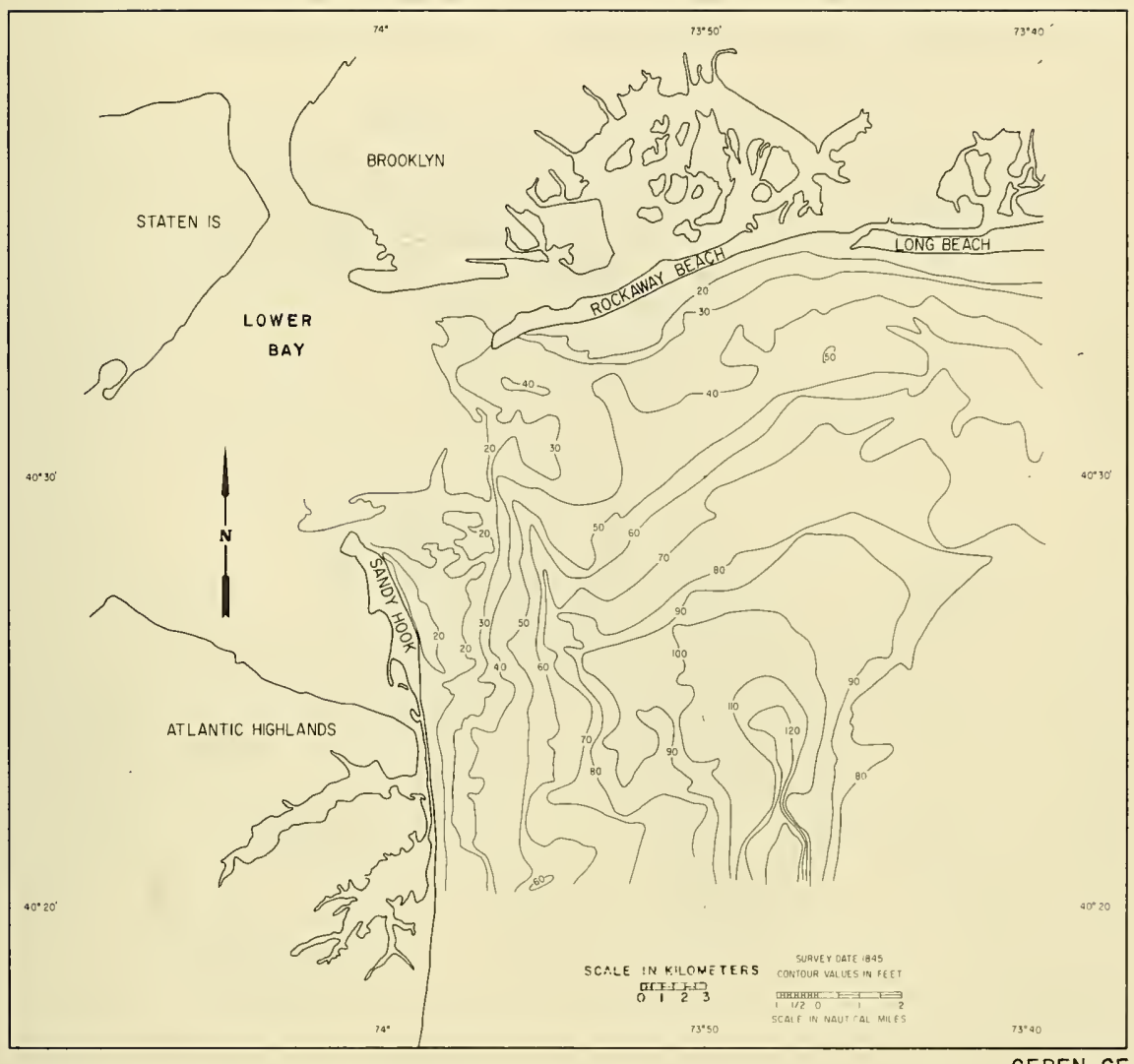

Figure 4. Bathymetry of the Shelf Outside Harbor Based on an 1845 Survey (Williams and Duane, in press) 


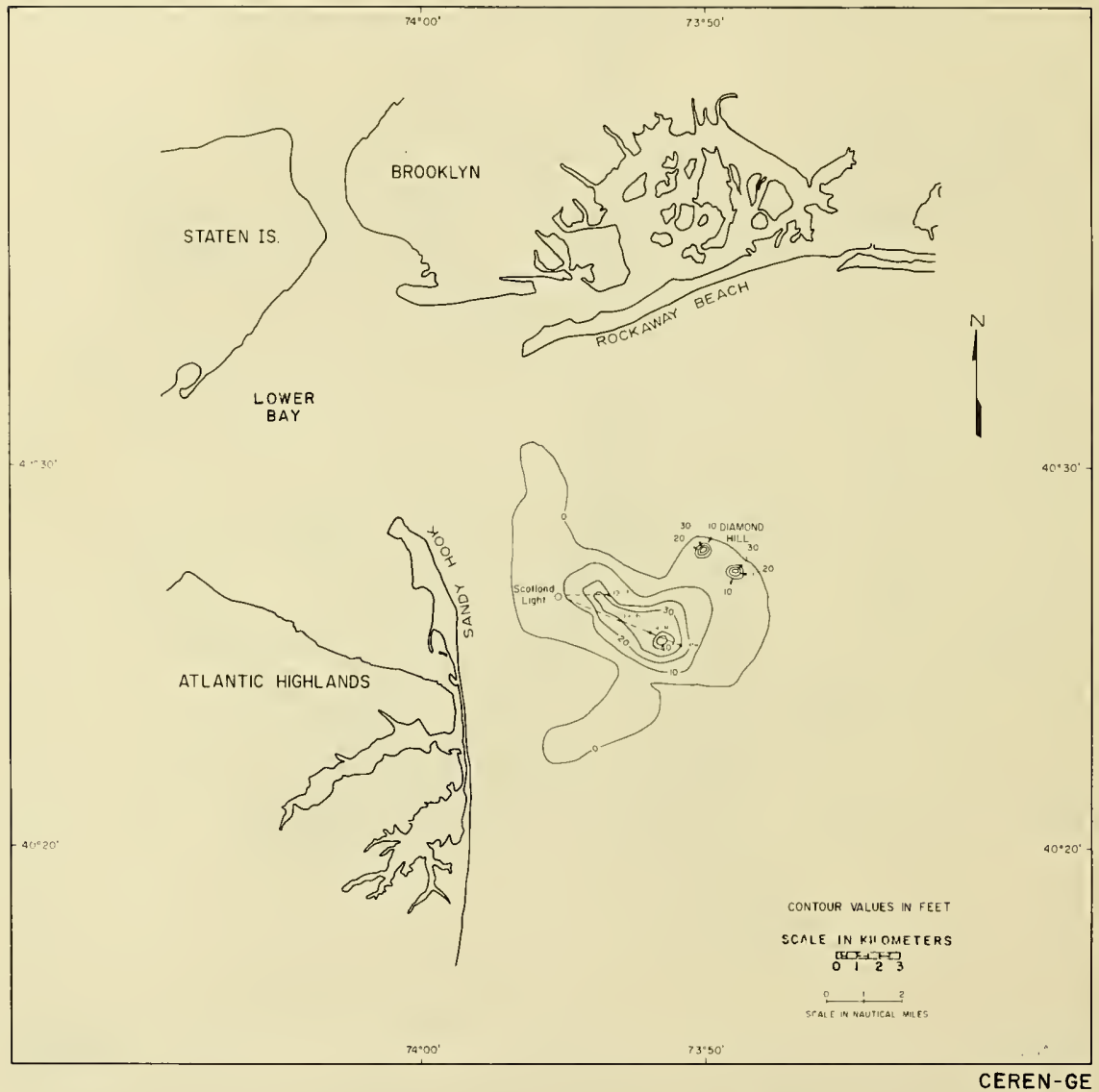

Figure 5. Isopach of Fill Material (Williams and Duane, in press) 


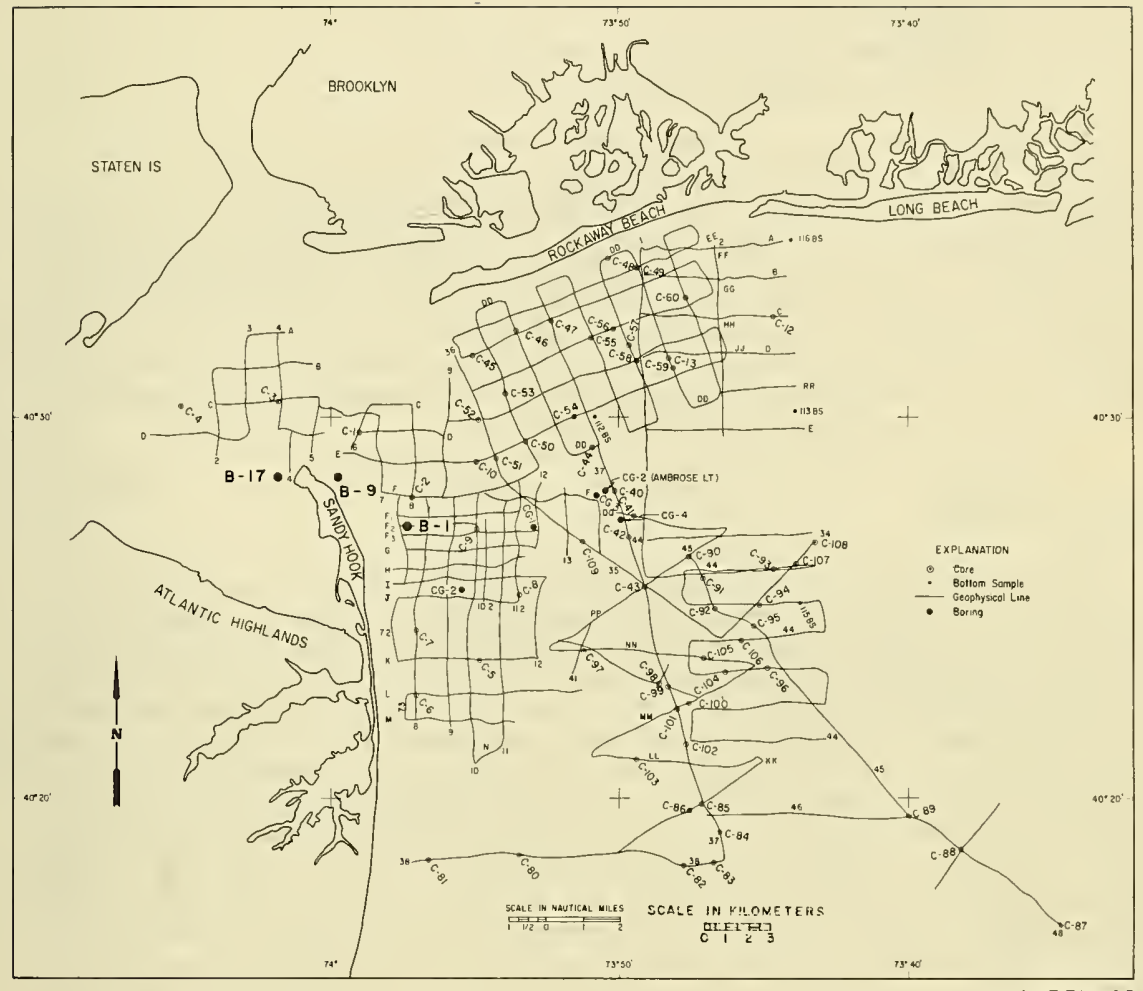

CEREN-GE

Figure 6. Track of Geophysical Reflection Studies and Location of Core, Boring and Sampling Sites of CERC's Inner Continental Shelf Study Program (ICONS) (Williams and Duane, in press) 
taken for foundation engineering studies for Coast Guard navigation buoys in the Bight. These indicate that gently southeast dipping Coastal Plain Strata underlie the Shelf off the Harbor. Shrewsbury Rocks, extending offshore from Long Branch, N.J., (Figure 3) mark the physiographic and geologic demarcation between deeply eroded Upper Cretaceous strata to the north and evenly truncated Tertiary Strata to the south (Figure 7) (Williams and Duane, in press).

Overlying the Coastal Plain sediments are sands, gravel and fine detritus which in part owe their origin to the ancestral Raritan and Hudson Rivers which flowed over the exposed Shelf during Pleistocene time. Additional material from melt water erosion of the terminal moraines of Long Island was deposited concurrently on the Shelf. ICONS geophysical records east of Sandy Hook show an elongate area containing complex sets of cross stratified Pleistocene sand and gravel up to 75 feet thick on top of deeply eroded Coastal Plain strata. The crossbed sediments are overlain by flat lying stratified sand with an average thickness of 15 feet (Williams and Field, 1971).

Stratigraphy of the sediments of the Inner New York Bight in the dump grounds follows:

Upper Cretaceous and Tertiary strata (sands, silts, clays and some gravels) form the base material of the Shelf of the Bight. Pleistocene glaciofluvial material was deposited unconformably upon the erosion surface represented by these sediments. In certain areas of the Bight, especially near ancestral river beds, east of Sandy Hook these sediments are crossbedded. Superimposed on the Pleistocene sediments are horizontal, sand deposits of variable thickness of Holocene age. Subbottom profiling and coring studies indicate the existence of a thin veneer of Holocene material near the dumping grounds. This material is covered by dredge spoils and sewage sludge. Ambiguity persists about the thickness of the waste materials on the present dumping grounds. Random core sampling in this area has shown accumulation of waste sediment having thickness of only a few centimeters. One core showed waste thickness of about one meter. This core, it is believed, was taken in a topographic low where such accumulation is more probable. The apparent absence of a thick accumulation of waste material on the ocean floor as revealed by ICONS cores and geophysical records indicates either resuspension and transport of this sediment or rapid biodegradation. Such a magnitude of biodegradation may be more true for the sewage sludge which has a higher organic content in contrast to excavation rubble or dredge muds.

c. Surface Sediments. A large percentage of the sediments found in the designated dredge spoil dumping area originate from dredging and maintenance of navigation channels in the Harbor. These channels are dredged to accommodate the large volumes of shipping into the Harbor.

Sediments of the Inner Harbor are generally fine grained sands and silts subject to continuous shifting by bottom currents. In the outer part of the Harbor, including Sandy Hook Bay, the bottom is typically 

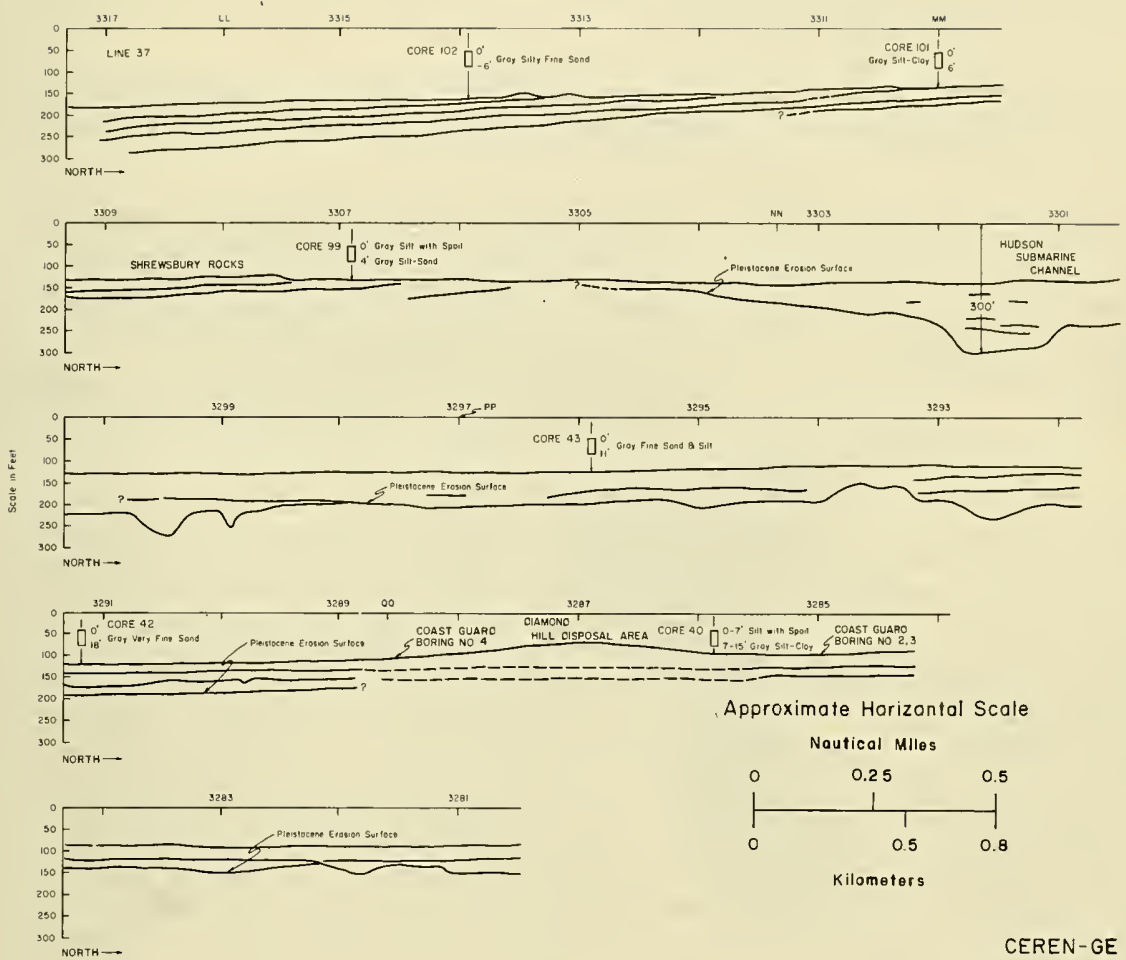

CEREN-GE

Figure 7. Stratigraphy of Sediments in the Vicinity of the Dumping Grounds as Revealed from Cores and Subbottom Profiling (Williams and Field, 1971) 
covered with coarser sands (Fig. 8). Sediment distribution and characteristics in both the Inner and Outer Harbor are affected by the nature of sediment from the Hudson River, the quantity and type of wastes discharged within the harbor, tidal circulation, and frequency of dredging.

Near the Harbor entrance, the sediments are coarser, consisting typically of sand and gravel. Further offshore, sand is the principal sediment with a few scattered patches of gravel (Fig. 8).

Near the dumping grounds the sediments are not typical of sediments found elsewhere in the Bight. These sediments are usually mixed, since they originate from different regions, and include medium or fine grained sands, muds with high organic content, and sewage sludge at different stages of degradation. The sediments of the dumping grounds can be termed anthropogenic because their deposition is not the result of natural processes. Certain physical properties of the sediments dredged and disposed of in the dumping area are given in Table 4.

There appears to be little natural sedimentation on the Continental Shelf of Bight at the present time. Topographic features, cut by rivers flowing across the Shelf when sea level was lower, have not been covered by more recent sediment deposition. The rivers carry little suspended sediment, and the large estuaries and lagoons along the coast appear to effectively trap this sediment (Meade, 1969). According to Gross (1970), there is little or no natural sediment deposition to dilute or bury ocean disposed wastes in this region. Removal of the waste sediments from the dumping grounds - at least the finer sediments - may be taking place as a result of lateral movement due to bottom currents, storm waves, internal waves and turbidity currents. The extent of lateral movement of the sediments of the dumping area is not satisfactorily documented. Turbidity currents probably play an important role in the removal of waste sediment. Because the dumping grounds are near the head of the Hudson Channel, it is possible that the channel acts as a conduit moving such sediments to deeper water in the form of density currents. The WHOI study concluded that a possible reason the Los Angeles area did not experience a degraded marine environment was because of canyons. So the nearness of the Hudson Canyon to the disposal grounds may be beneficial provided that the ecological damage in the Canyon, resulting from the presence of polluted sediments, is not too great.

\section{Water Motion and Circulation Characteristics}

The water motion and circulation characteristics of the Bight have been studied in relation to dispersion patterns of waste materials disposed of in the area. (Ketchum and Ford, 1948; Ketchum, et al, 1951; Redfield and Walford, 1951; Beyer, 1955; Saila, 1968; Buelow, 1968; Sandy Hook Laboratory, 1972). Hydrographic studies of the Bight have also been undertaken by Bowman and Weyl (1972).

No comprehensive synoptic hydrographic studies of the nearshore area of the Bight have been made, and complete understanding of the surface 


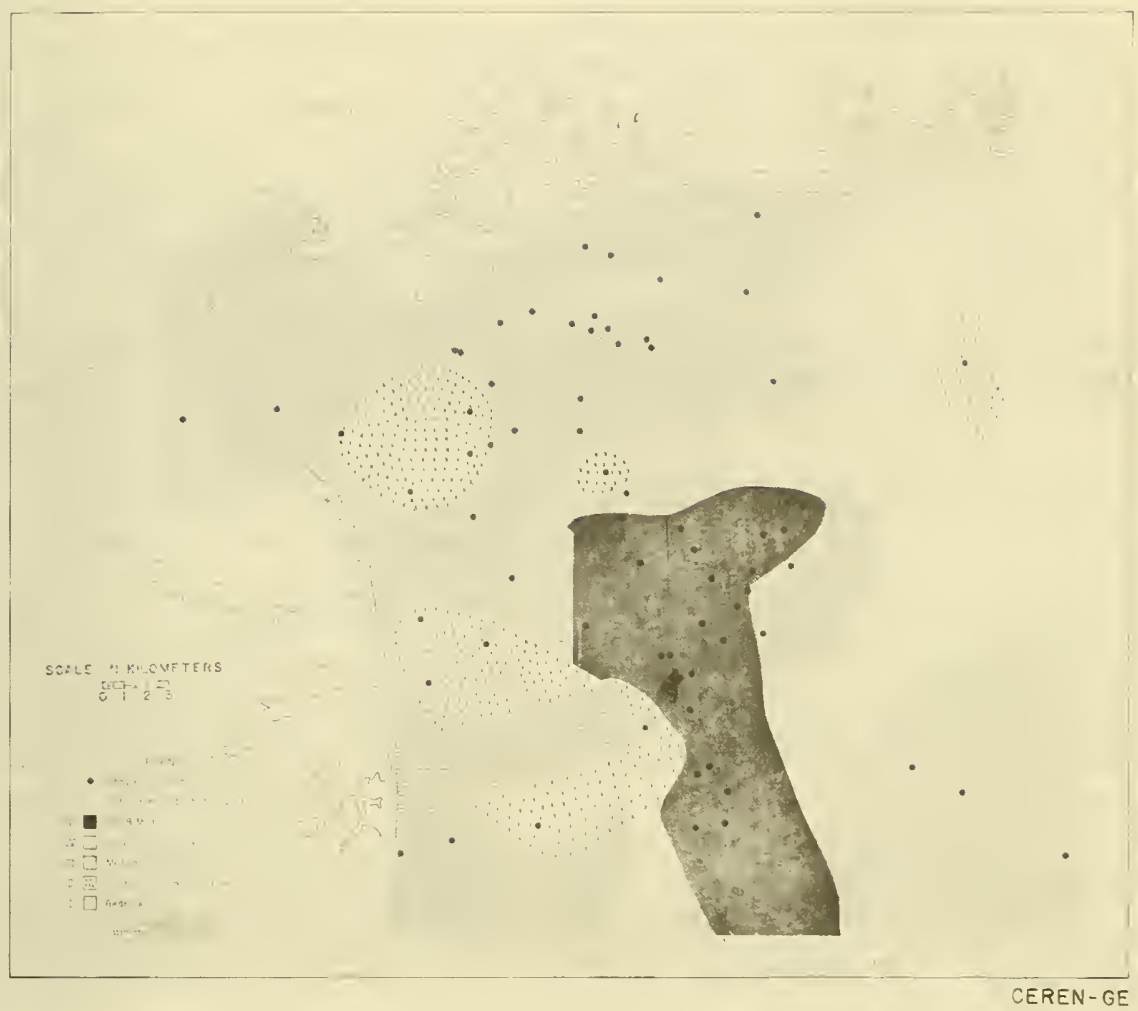

Figure 8. Sediment Distribution in Lower New York Bay and on the nearby Continental Shelf (Williams and Duane, in press) 
Table 4. Physical Properties of Sediment Dredged in the New York Metropolitan Area

\begin{tabular}{|l|c|c|c|c|c|}
\hline \multicolumn{1}{|c|}{ Dredged Area } & $\begin{array}{c}\text { Years of } \\
\text { Observation }\end{array}$ & Median Grain Size & Grain Density & $\begin{array}{c}\text { Bulk Density } \\
\text { (min situ) } \\
\left(\mathrm{g} / \mathrm{cm}^{3}\right)\end{array}$ & $\begin{array}{c}\text { Porosity } \\
\text { (percent) }\end{array}$ \\
\hline Hudson River & $1955-1968$ & 44 & 2.64 & 1.24 & 85 \\
& & 65 & 2.69 & 1.24 \\
& 28 & 2.66 & 1.43 & 73 \\
\hline Lower Bayt & $1954-1967$ & 55 & 2.55 & 1.34 & 78 \\
& & 110 & 2.69 & 1.40 & 75 \\
& & 46 & - & 1.3 & 79 \\
\hline New York- & $1958-1967$ & 350 & 2.79 & 1.43 & - \\
New Jersey Channels & & 41 & 2.69 & 1.31 & 80 \\
\hline Raritan River & $1958-1967$ & 9 & 2.62 & 1.42 & 75 \\
\hline Ambrose Channel & $1956-1968$ & 160 & 2.625 & 2.09 & 32 \\
& & 220 & 2.636 & 1.82 & 50 \\
\hline Sandy Hook Channel & $1960-1968$ & 250 & 1.89 & 1.89 & 47 \\
& & 220 & 1.98 & - & 42 \\
\hline South Shore & $1955-1968$ & 530 & 2.67 & 2.07 & 38 \\
Long Island & & 410 & - & 1.92 & 40 \\
\hline \hline
\end{tabular}

† Percent Loss on Ignition: $15.0,13.0$, and 2.3.

after Gross, 1969

* One gram per cubic centimeter is equivalent to one metric ton per cubic meter or 62.4 pounds per cubic foot. 
and bottom circulation in the area of the disposal grounds has not been obtained. The reason for this lack of understanding is that the Bight dumping grounds are not strictly marine but have estuarine characteristics. The hydrographic conditions in this area constantly change as freshwater flows from the Hudson and Raritan Rivers into the oceanic environment. Generally, conditions in the Bight are similar to those off the mouths of 1 arge rivers.

The flow of the Hudson and Raritan Rivers varies seasonally from less than $0.6 \times 10^{9}$ to more than $1.3 \times 10^{9}$ cubic feet per day. With such an influx freshwater, it would be expected that the distribution of physical properties would be greatly affected. Paradoxically, a study of hydrographic conditions in the Bight by Ketchum, et al (1951) has shown that when-the river flow was great, a steady state condition existed and the distribution of properties was explainable. When the river flow was low, the patterns were erratic, changeable, and unpredictable.

To maintain a steady-state condition within the Bight, nontidal drift of mixed water in a net seaward direction must be taking place. To counteract rapid flushing, and to maintain the steady-state condition, a large quantity of ocean water must also enter the area. This oceanic counterdrift would be expected to be rich in oxygen and nutrients. The study by Ketchum and his associates, concluded that an active circulation pattern exists in the Bight having a beneficial cleansing action on whatever pollutants enter the area. The rate of flushing was estimated to be from 6 to 10 days, and to be independent of the river flows, but dependent on tidal oscillations.

This active circulation pattern within the Bight was inferred by studying the spatial distribution of properties and by identification of water masses and boundary conditions. Although it appears correct in explaining total water mass exchange and drift, it does not answer immediate questions concerning circulation patterns within the dumping grounds.

The Sandy Hook Laboratory (SHL) attempted to directly measure the circulation in the Bight related to the movement and dispersal of dumped materials. SHL established a sampling grid of 23 hydrographic stations in part of the Bight (Figure 9) and made periodic measurements of temperature, salinity, and dissolved oxygen. Attempts to measure directly velocity, current direction, and particulate transports were made, but were partially unsuccessful. Three of four current meters placed at fixed stations, 40 feet above the bottom within the study area (Points A, B, C, Figure 9), gave satisfactory records for only limited periods. The results of this current data are discussed in the section on bottom circulation. Estimates of surface and bottom sediment transport were obtained by SHL using seabed and surface drifters. The Seabed drifter used was a positively buoyant plastic saucer (diameter $18 \mathrm{~cm}$ ) fastened to a small diameter stem $54 \mathrm{~cm}$ long. The free end of this stem was weighted so that the whole drifter had a slight negative buoyancy. Surface drifters were small bottles ballasted to float vertically and to 


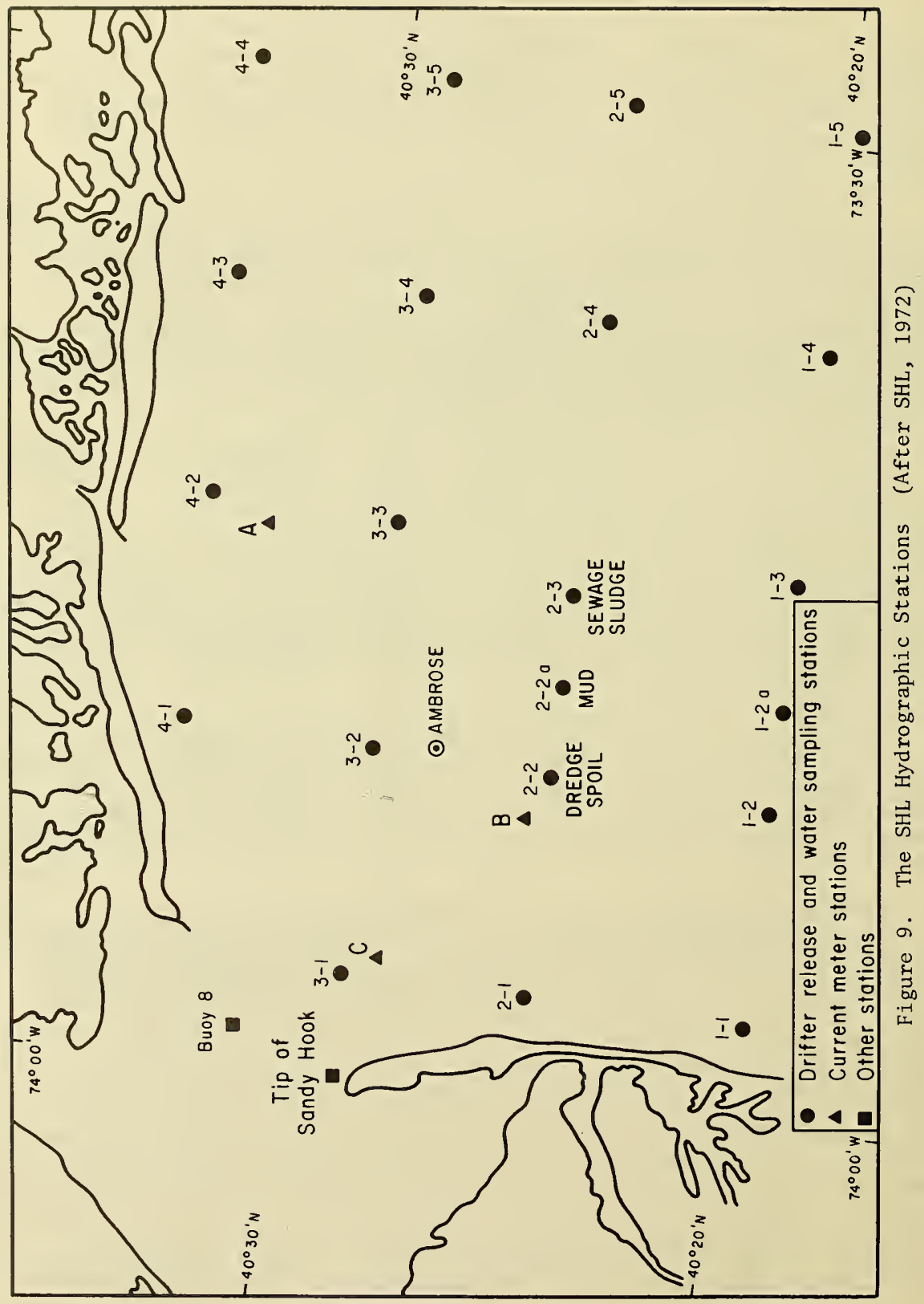


present little above surface exposure reducing wind effects. The analysis of circulation patterns was based on the limited current meter data and on returns from about 4,000 surface and seabed drifters, released during 1969. The history of returns for these drifters is shown in Figure 10. Details on the construction and operation of drifters can be found in papers by (Bumpus, (1965), Harrison, et al, (1967).

a. Surface Circulation. Knowledge of surface currents is important in understanding the dispersion of surface pollutants near the dumping grounds. Surface circulation of the waters of the Bight is controlled by tides and prevailing winds. It is difficult to determine the net effect of tidal and wind-driven surface circulation on waste dispersion in the absence of comprehensive synoptic hydrographic surveys, because both tides and winds are dependent on time of day and season of year. However the following general remarks can be made:

(1) Tidal Circulation. The New York Harbor tidal circulation has been studied by Marmer (1935), and Jeffries (1962). Under flood conditions, water flows into the Lower Bay through Ambrose Channel while ebbing still occurs at the surface and along the bottom of the channel. The ebb in the Lower Bay is generally stronger than the flood by 10 percent or more, so, in addition to the net transport of water from the Hudson River, there is a net flow of water in a seaward direction. Net currents in Raritan and Lower Bays are shown in Figure 11. The tidal pattern in Upper Bay, south of Manhattan, is complicated by cross currents due to differences in ebb and flood, and effects of tidal resonance. Tidal currents in the Narrows are quite strong.

The nearshore tidal circulation, along the New Jersey and Long Island coasts near the entrance to the Harbor, is quite different than the offshore circulation. According to the United States Coast Pilot for Area 2 (Cape Cod to Sandy Hook), tidal currents near the Fire Island Lighted Whistle Buoy, have a mean velocity of about 0.2 knots west on the flood and east on the ebb. At the seaward end of Ambrose Channe1, the mean velocity of the tidal currents at flood is 1.7 knots, at ebb, 2.3 knots.

Tidal currents are less significant offshore of the present dumping grounds than in the nearshore area. Velocities are probably no more than 0.3 knots shifting direction continuously to the right in a clockwise direction with each tidal cycle of about 12.4 hours. This direction shift would have an average rate of about $30^{\prime}$ per hour and would have the effect of isotropically dispersing any suspended lightweight material in the upper part of the water column.

(2) Wind-Driven Circulation. Wind-driven circulation in the New York Bight is far more significant than tidal circulation in the dispersal of suspended waste material in the surface waters. Circulation of surface water due to wind-driven surface currents at the ocean dumping grounds similarly cannot be deduced without synoptic field investigations and measurements. On the basis of known wind patterns, the following generalizations can tentatively be made. 
1969

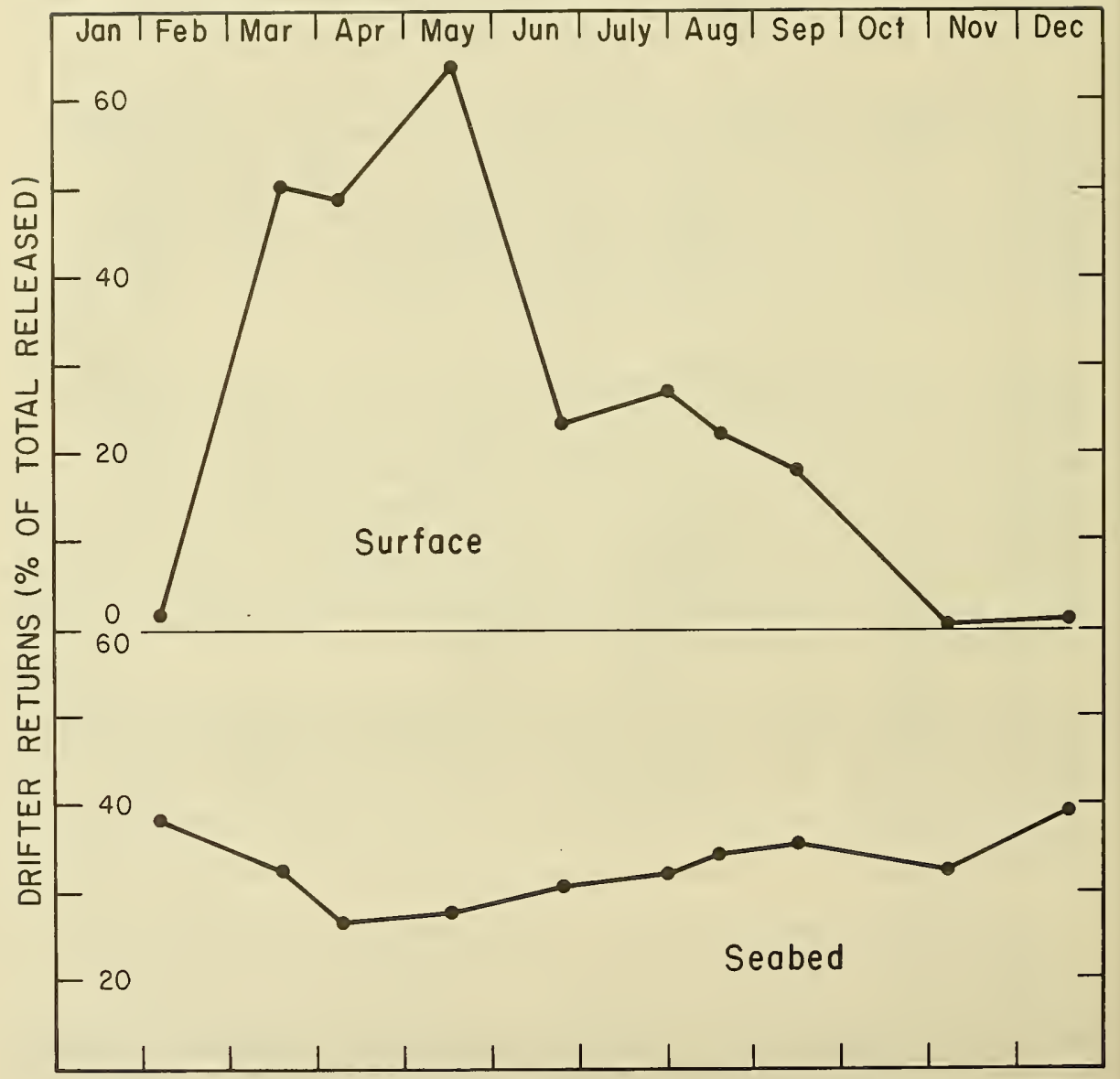

Figure 10. Time History of Drifter Returns Used in Water Circulation Studies (After SHL, 1972) 


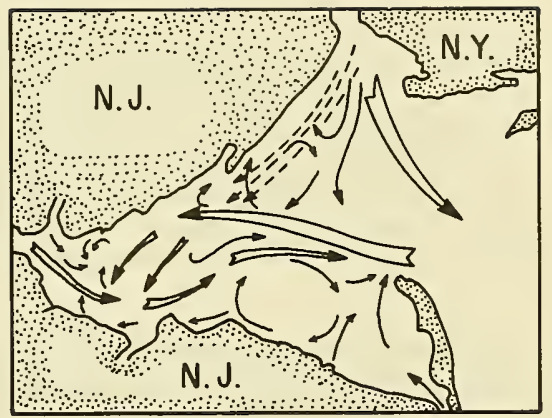

Figure 11. Net Surface Currents in Raritan and Lower Bays (After Jeffries, 1962) 
Under extreme storm conditions, the largest velocities of surface currents due to winds in the area are about 1.5 knots. Such strong currents would be due to gales with force of 40 miles per hour, predominantly from the northwest. Since the prevailing winds are from the northwest, about 10 months of the year, the net movement of surface water and its suspended material, during these months, would be in a south or southeasterly direction.

In July and August, when prevailing winds are southeasterly, net movement of surface water and of suspended matter in the upper water layer would be in a north, northeast direction. Such surface flow was confirmed by the SHL drifter studies.

The layer of water that may be affected by storm winds would be the upper layer, 0 to 50 feet thick. Below that depth, net movement of the water due to subsurface currents may be in any direction and even in a direction opposite to the surface flow.

(3) General Surface Circulation. General patterns of surface circulation can be obtained inexpensively over a large area by the use of surface drifters. Such a surface drifter study was undertaken by the Sandy Hook Laboratory.

Surface drift bottles were released intermittently at several points of the Bight (Figure 9) to determine the seasonal and spatial character of the surface currents. Of 1,886 surface drifters released by SHL, 497 (26 percent) were recovered. The total percent recovery of surface drifters is illustrated in Figure 12, and the origin of surface drifters recovered on the Long Island and New Jersey shores on Figures 13 and 14. To estimate speed, the SHL study assumed a straight-line course between release and recovery. To estimate time at sea, the duration between release and recovery was used. By this method, changes in the direction of currents were only roughly depicted, and speed could be underestimated.

The SHL study concluded that there is a general clockwise circulation in the Bight, which was associated with bifurcation at the head of the Hudson Channel. Surface drift patterns suggested strong seasonal surface circulation. During winter, surface flow was predominantly southeast, in summer the flow tended northward toward the south coast of Long Island. These results are in agreement with earlier observations of Bumpus and Lauzier (1965).

Density patterns derived from temperature-salinity values for a cross section aligned with the axis of the Hudson Channel near Station $C$ where current measurements were obtained, infer according to the SHL study, an estuarine type of circulation. Although not quantitatively definable, according to the SHL study, a landward flow of water near the bottom should occur preferentially in the Hudson Channel region of the Bight. The force driving the estuarine and coastal circulation, according to the SHL study, is the horizontal pressure gradient. 


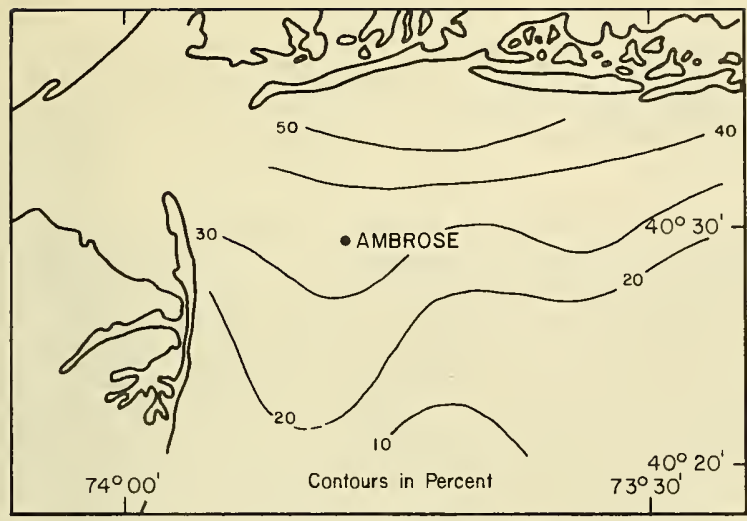

Figure 12.

Surface Drifter

Returns Total

Percent Recovery

Lines for 1969

(After SHL, 1972)

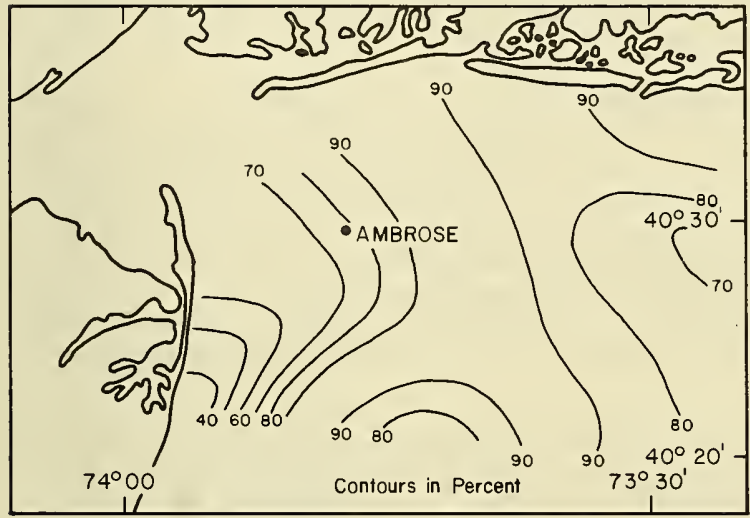

Figure 13.

Origin of Surface Drifters Recovered on Long Island (After SHL, 1972)

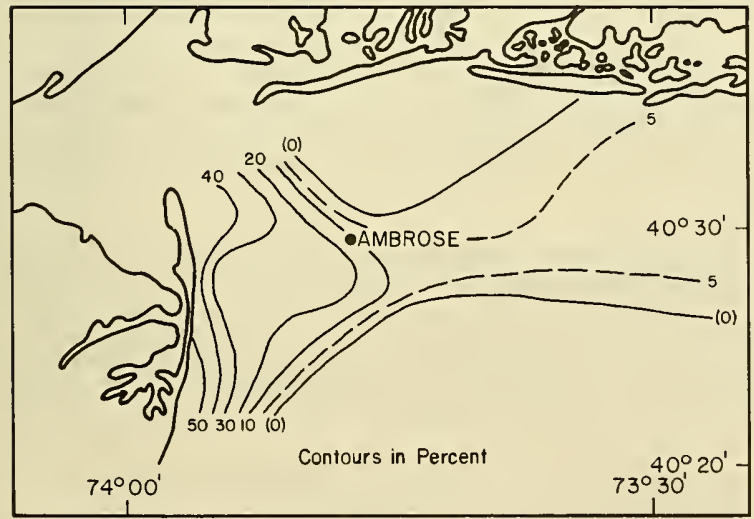

Figure 14.

Origin of Surface Drifters Recovered on New Jersey Coast (After SHL, 1972 
b. Bottom Circulation. A study of bottom circulation of waters outside the Harbor was attempted by the SHL using current meters and bottom drifters. Current measurements were made by the SHL for only three stations A, B, C (Figure 9).

At station A, 3.5 miles south of Atlantic Beach, bottom and mid-depth observations were made in late June 1969. At station B, 2.5 miles southwest of Ambrose Light, bottom measurements were taken in late February 1969. At station C, 3.5 miles east of Sandy Hook, bottom measurements were taken in late May - early June 1969. The records are few, nonsynoptic and cover only short periods. It is difficult to generalize from only three measurements the total bottom circulation of the Bight, or to correlate with drifter studies as the SHL attempted to do. Although not conclusive, the results of these current measurements taken by SHL are illustrated in Figure 15. For each of the three stations A, B, C, in this figure, the progressive vector diagram is presented for the valid portion of the record.

On the basis of these current measurements, the following conclusions were reached by the SHL study. At station A, according to bottom-drifter analysis, the bottom flow should be predominantly east. For the period of the record (late June) local winds were variable but generally from the south. The current-meter measurements (Figure 15) show such an initial eastward movement of mid-depth and bottom water. One week later, however, the mid-depth flow swings in a northeast direction, bottom drift shifted to a southeast direction. The average net drift at point A was $3.3 \mathrm{miles}$ per day for mid-depth water, and $1.9 \mathrm{miles}$ per day for bottom water.

At station B, the station nearest the dumping grounds, bottom water flow (February) was generally east, switching later toward the north until the record became invalid. The average net drift for the entire period was $3.9 \mathrm{miles}$ per day.

Finally, at station C (1ate May - early June) the path of the inferred bottom flow was northwest into the Bay. Figure 15 shows there was substantial tidal oscillation, but net drift followed a heading of about $320^{\circ}$ True. The average net drift over the period, according to the SHL study, was 4.2 miles per day.

In addition to the current measurements, bottom seabed drifters were also released at stations shown in Figure 9.

The total percent recovery of seabed drifters is shown in Figure 16. of 2,190 seabed drifters released in 1969,710 (32 percent) were recovered over a period of 6 months from beaches of Long Island. The origins of seabed drifters recovered in the Hudson Estuary and the Long Island and New Jersey coasts are shown in Figures $17,18,19$. SHL data suggest a strong flow at the bottum along the axis of the Hudson-Ambrose Channel northward and towards Long Island and into the mouth of the Hudson Estuary. Few drifters were recovered in the bay, but low drifter return was 


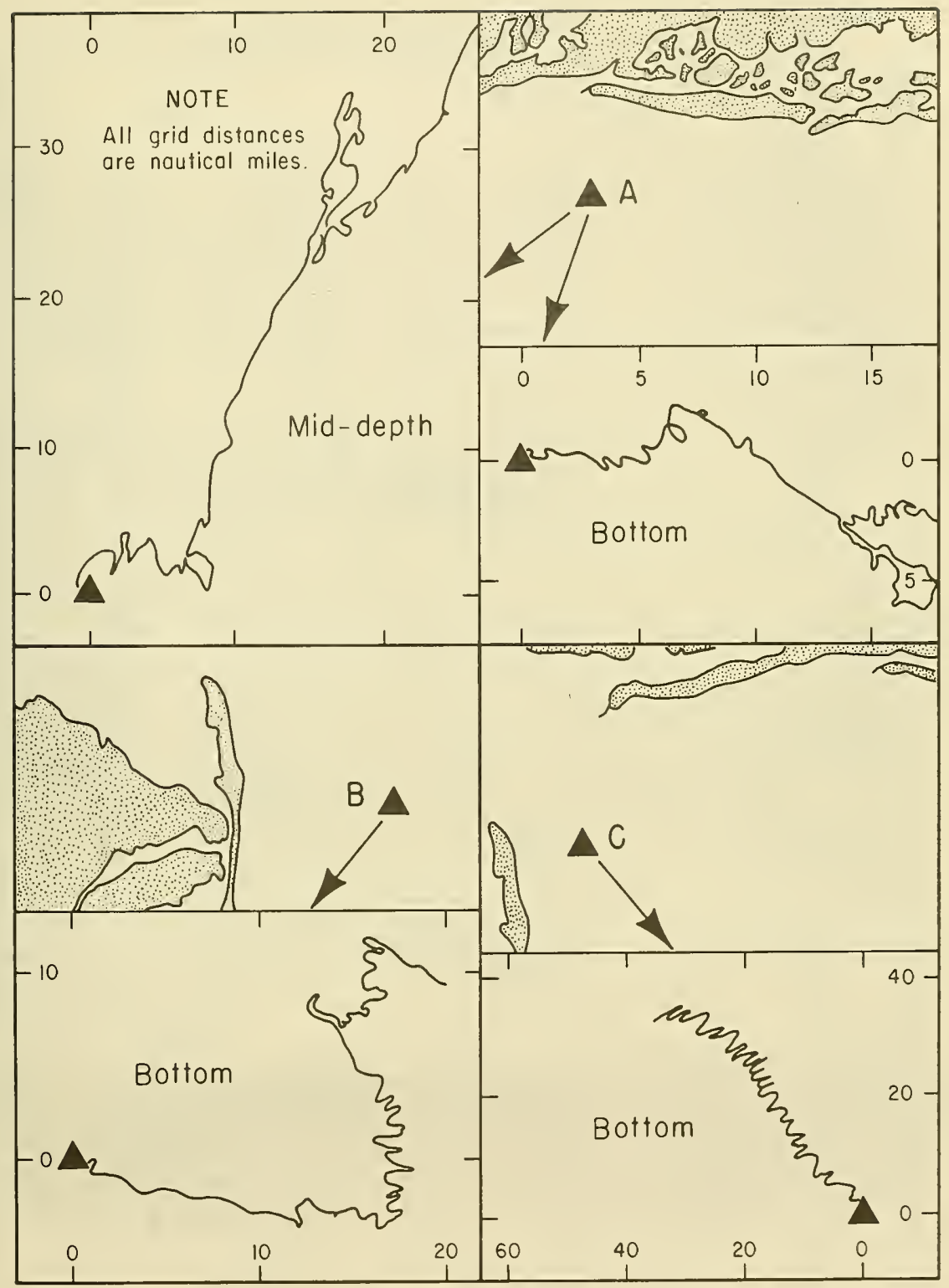

Figure 15. Progressive Vector Representation of Current Meter-Data from Stations A, B, and C of Sandy Hook Laboratory (After SHL, 1972) 


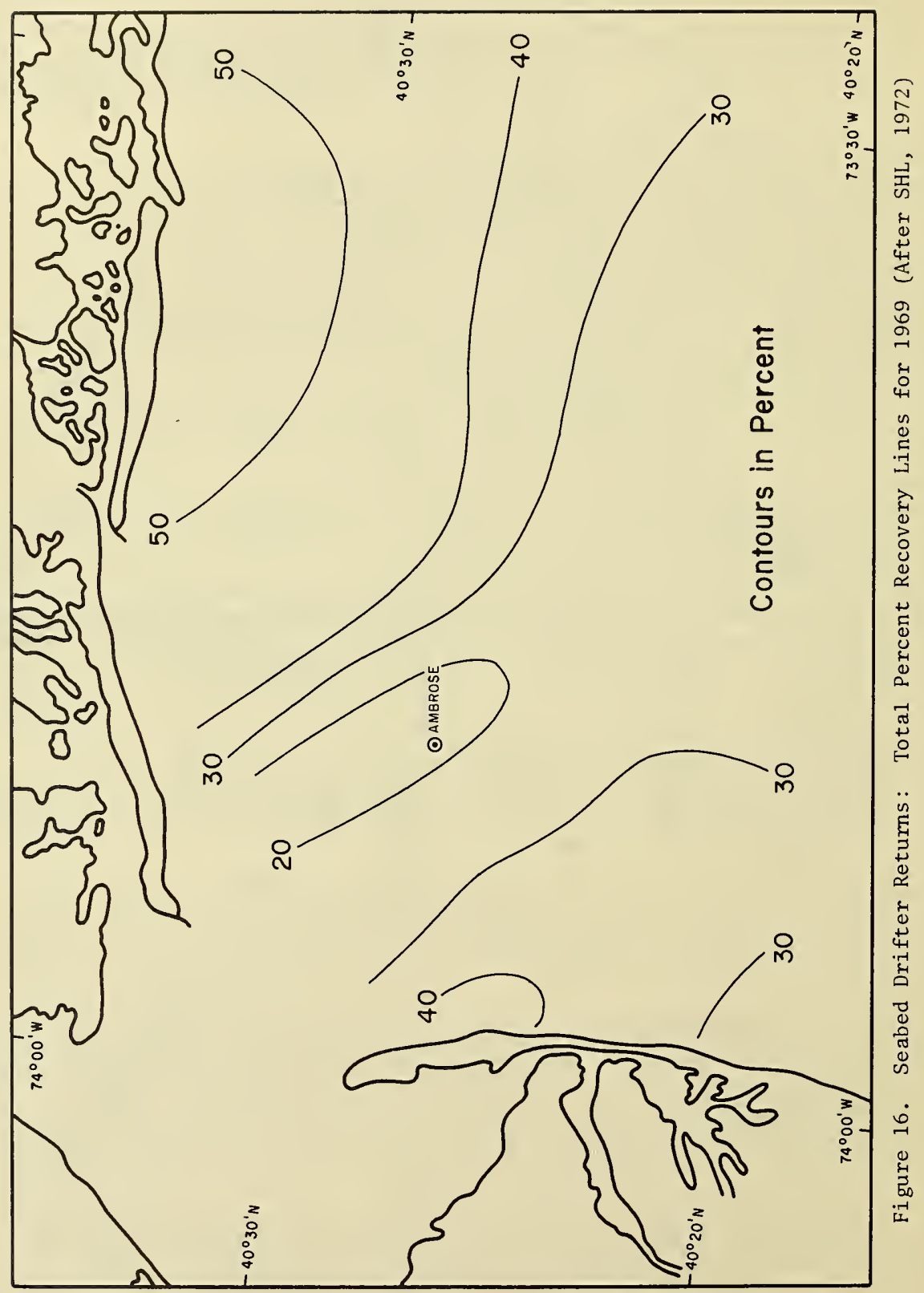



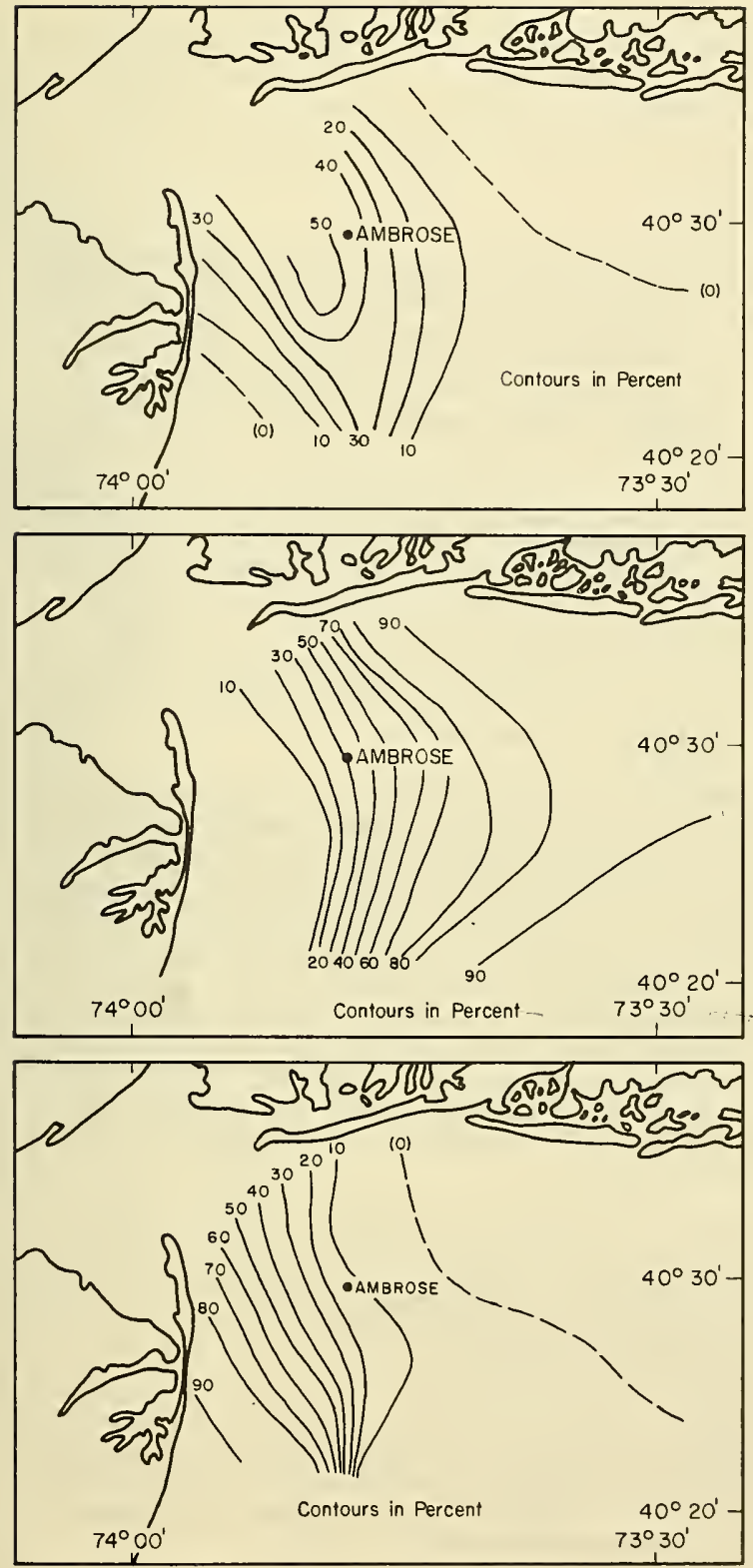

Figure 17.

Origin of Seabed Drifters Recovered in Hudson Estuary Expressed and Contoured as Percentages of all Returns from Individual Stations (After SHL, 1972)

Figure 18.

Origin of Seabed Drifters Recovered on Long Island (After SHL, 1972)
Figure 19.

Origin of Seabed Drifters Recovered on New Jersey

Coast (After SHL, 1972) 
attributed by SHL to public inaccessibility to the area, reduced drifter buoyancy, or other forms of drifter entrapment. On the basis of bottom drifter returns (Figure 10), SHL concluded that the bottom circulation of this region of the Bight undergoes mild seasonal variation.

\section{Chemical Characteristics}

Physical-chemical studies of the Bight in the past (Ketchum, Redfield, and Ayers, 1951; Redfield and Walford, 1951) have described the distribution of temperature, salinity, dissolved oxygen and iron in the area. Iron content of sediments in and northeast of the dumping grounds has been studied by Corwin and Ketchum (1956). Salinity, temperature, total phosphorus, total iron and chloroph11-a data have been reported by Ketchum, Yentsch and Corwin (1958).

Buelow, Pringle and Verber (1968), analyzed water extracts of sediment samples taken near the sewage sludge dumping ground for copper, zinc, chromium and lead. Limited trace metal analyses were also conducted on black quahog Arctica islandica samples. Gross (1970) provided more information on the chemical nature of sediment in the Bight. The study correlated high concentrations of metals with carbon-rich waste deposits. A later investigation by Gross et al, (1971) measured the copper, lead, silver and chromium content of surface deposits.

SHL (1972) determined concentrations of phosphorus (ortho, organic, meta and total), nitrate, total iron, dissolved oxygen, and chlorophyl1-a in water samples, and measured temperature, salinity, turbidity and $\mathrm{pH}$. Sediment samples were analyzed for heavy metals, petrochemicals, pesticide metabolites and redox potential to correlate these characteristics with the distribution of lenthic organisms. Figure 20 shows the stations occupied for chemical studies. Samples were collected on 27 cruises from late January 1969 to mid-July 1970. Initially, stations on eastwest transects through the sewage sludge and acid disposal areas were sampled bimonthly. These included Stations $69,70,71,75,76,77$, and 78. Stations located on transects to the north, south and between the above stations were sampled monthly. This pattern included Stations $66,67,68,72,73,74,79,80$, and 81 .

Table 5 summarizes the ranges of values for certain chemical parameters measured in the Bight by the SHL. Fig. 21 shows the seasonal variation of properties at two stations in the Bight determined by Ketchum, et al, (1951). One station was near Scotland Lightship, the other just southeast of the dumping grounds.

a. Temperature and Salinity. Temperature and salinity data for the waters of the New York Bight have been obtained by a number of investigations studying physical-chemical properties (Ketchum, et al, 1951; SHL, 1972; Bowman and Wey1, 1972). Some of these data have been summarized in the report by Horne and his associates (1971).

The temperature and salinity of the Bight vary seasonally. Greater 


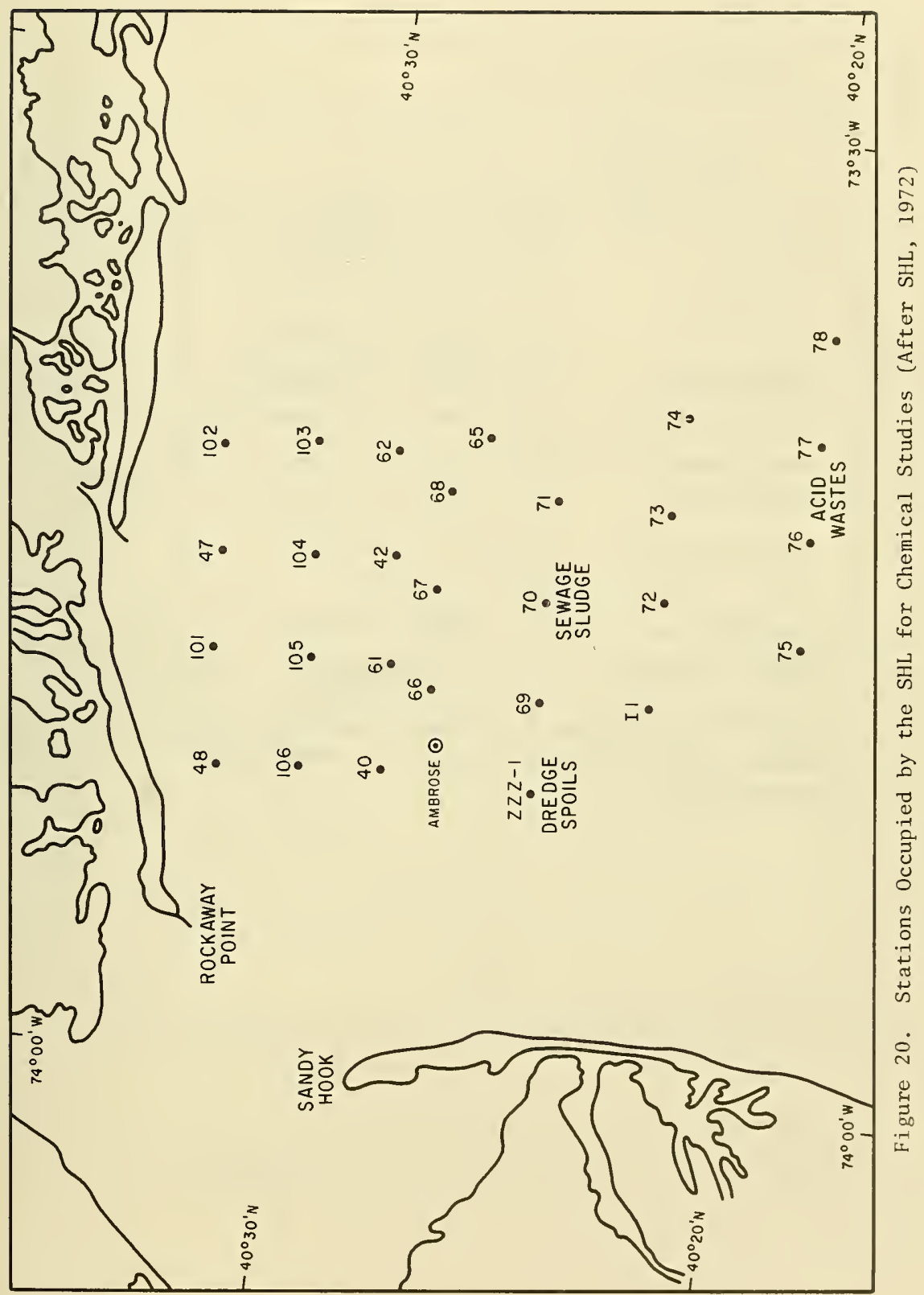


Table 5. Ranges of Chemical Data Measurements Near the New York Dumping Grounds.

\begin{tabular}{|l||c|}
\hline \multicolumn{1}{|c||}{ Chemical Variable } & Range \\
\hline \hline Total iron & 0 to $37.3 \mu \mathrm{g}$-at $/ 1 *$ \\
Chlorophyll-a & 0.38 to $33.3 \mu \mathrm{g}$-at $/ 1$ \\
Nitrate & 0 to $3.28 \mu \mathrm{g}$-at $/ 1$ \\
Orthophosphate & 0.02 to $5.64 \mu \mathrm{g}$-at $/ 1$ \\
Organic phosphate & 0.04 to $2.28 \mu \mathrm{g}$-at $/ 1$ \\
Metaphosphate & 0.01 to $2.35 \mu \mathrm{g}$-at $/ 1$ \\
Total phosphate & 0.84 to $7.48 \mu \mathrm{g}$-at $/ 1$ \\
Dissolved oxygen & 2.0 to $15.2 \mathrm{ppm} \dagger$ \\
pH & 7.10 to 8.40 \\
Lead in sediment & 0.55 to $249 \mathrm{ppm}$ \\
Copper in sediment & 0.013 to $338 \mathrm{ppm}$ \\
Chromium in sediment & 0.25 to $197 \mathrm{ppm}$ \\
\hline * microgram-atom per liter & \multicolumn{2}{c}{$\mathrm{after}$ SHL 1972} \\
† parts per million &
\end{tabular}



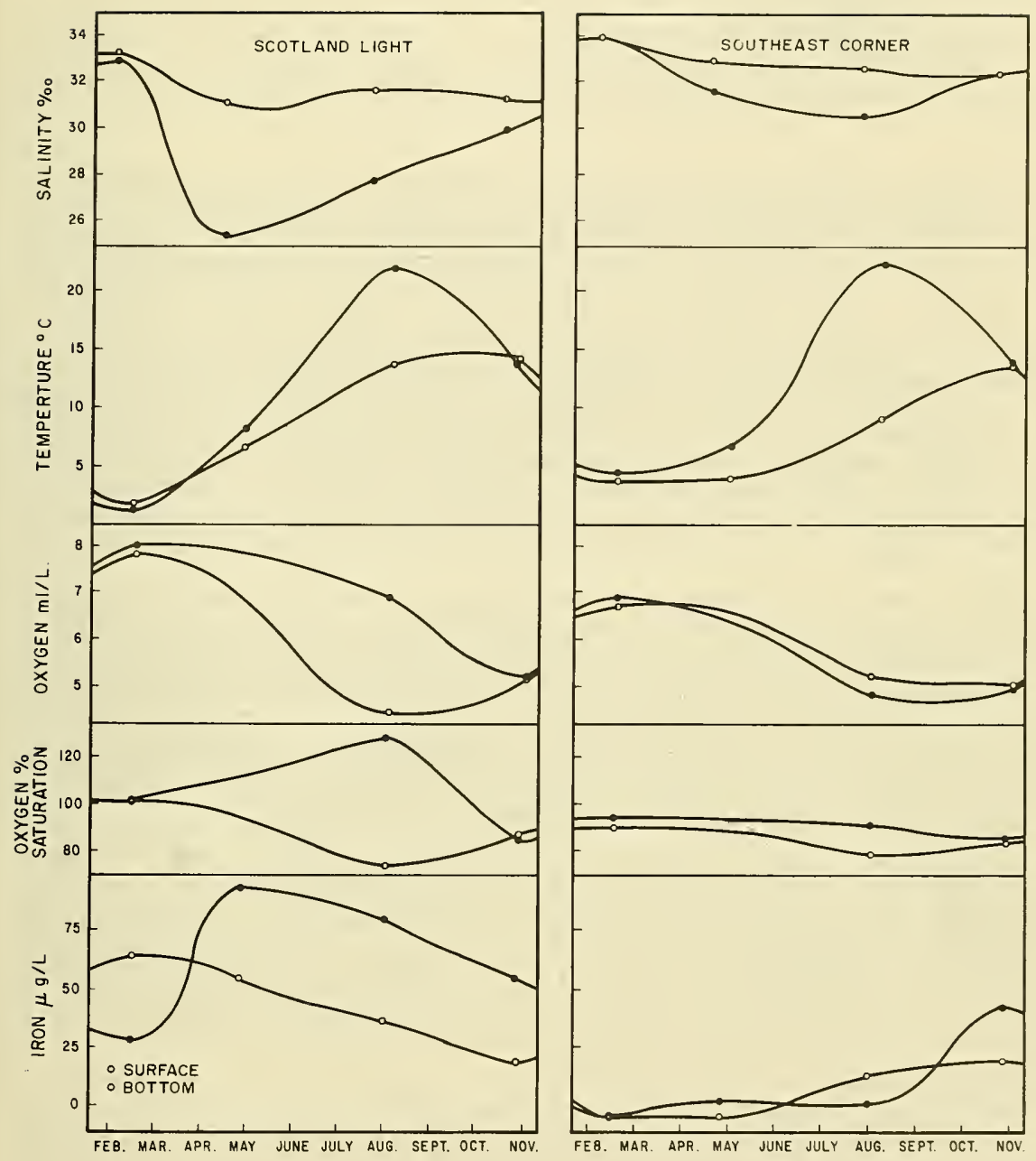

Figure 21. Seasonal Variation of Certain Physical Chemical Properties at Two Stations in the New York Bight (After Ketchum, et al., 1951) 
variation occurs near the mouth of the Harbor estuary where large flows of fresh water from the rivers enter. The flow of the Hudson and Raritan Rivers varies seasonally from less than $0.6 \times 10^{9}$ cubic feet to more than $1.3 \times 10^{9}$ cubic feet per day. This flow, in addition to other seasonal variations, affects the physical-chemical properties of the nearshore waters.

During the winter, in the absence of a thermocline, the waters become vertically homogeneous. Waters near the shore are colder and less saline; further offshore, the waters are warmer and more saline. A tongue of warmer ocean water is found along the Hudson Canyon (Horne, et al, 1971). Water temperature near the shore reaches a low of around $0^{\circ} \mathrm{C}$; offshore water fluctuates around $5^{\circ} \mathrm{C}$. The salinity varies also from 31 parts per thousand $(0 / 00)$ nearshore to $340 / 00$ offshore, with lower salinities at the mouth of the Hudson River. During spring, large flows of warmer, fresh water enter the Bight. This water stays on the surface, and establishes the beginning of a thermocline. The temperature difference between surface and bottom temperatures, at this time, is about $4^{\circ} \mathrm{C}$. During April, surface temperature varies from a little less than $7^{\circ} \mathrm{C}$ to over $8^{\circ} \mathrm{C}$, and salinities vary from $200 / 00$ at the Hudson River mouth to $320 / 00$ offshore.

During the summer, the thermocline becomes pronounced; surface temperatures vary between 20 and $25^{\circ} \mathrm{C}$, and bottom temperatures vary from under $10^{\circ} \mathrm{C}$ in the Hudson Canyon to $20^{\circ} \mathrm{C}$ elsewhere. Temperatures differ $5^{\circ}$ to $6^{\circ} \mathrm{C}$ offshore and over the Hudson Canyon. Surface salinity varies from 25 $0 / 00$ to $32 \mathrm{0} / 00$; the lower values are near the mouth of the river. Bottom salinity varies from $280 / 00$ to over $320 / 00$ offshore. The difference in salinity between surface and bottom ranges from a maximum of $30 / 00$ near the mouth of the estuary to a slight value offshore.

In autumn, the temperature-salinity structure is re-established. The temperature drops and salinity increases as the river flow decreases. The coldest water is again found onshore. Salinities vary from $270 / 00$ to $330 / 00$ and temperatures from $10^{\circ} \mathrm{C}-15^{\circ} \mathrm{C}$. Figure 21 illustrates seasonal variation in salinity and temperature at two stations in the Bight, measured by Ketchum, et al, (1951). The SHL investigation confirmed Ketchum's results. Low salinity was found in the surface waters moving from New York Harbor to the southwest.

b. Dissolved Oxygen. Oxygen content is an important measure of seawater's ability to support life. Dissolved oxygen (DO) concentration in the sea varies with temperature, salinity, biological processes, and degree of mixing.

Oxygen content of the waters in and around the dumping grounds of the Bight varies seasonally. (Fig. 21). Reduction of the DO in bottom waters in this area has been correlated with biochemical oxygen demand (B.O.D.) of the organically rich waste materials. 
WHOI's studies in 1948-49 showed the oxygen content near the bottom of the dredge disposal grounds to be 61 percent of saturation and 50 percent in the sludge disposal area. In July 1964, the WHOI investigation found an oxygen minimum (which is considered normal for summer months), and in 1969 oxygen content in the sludge dump area had dropped to 27 percent of saturation (Ketchum, 1970).

Oxygen content of sea water near the bottom, compared to surface concentration, is lower during the summer months; concentration between surface and bottom levels differs from 2 to 13 parts per million (ppm). These differences diminish with the breakdown of the thermocline in October-November.

Reduced values of DO in bottom waters were found during summer in both the sewage sludge and dredge spoil disposal areas by the SHL. According to the SHL study, DO in the dumping grounds is 2-3 ppm less than in water outside the dump area at the same depth, and the DO level in bottom water over the sewage sludge dump is frequently less than $2 \mathrm{ppm}$ from late July to mid-October. This level is insufficient to support life. On the average, dissolved oxygen ranged from $2.0 \mathrm{ppm}$ to $15.2 \mathrm{ppm}$ depending on sampling sites, season, and depth.

Fig. 22 shows the DO content of surface and bottom water for a cross section along both the sewer sludge and the dredge spoils dumping sites. The sparcity of data precludes statistically significant conclusions and the quantification of the B.O.D. in the area of the dumping grounds.

c. Nutrients. In the Bight, concentrations of natural nutrients such as phosphorus and nitrogen vary seasonally. Nitrate-nitrogen concentration in the surface waters is sometimes completely exhausted; small concentrations of phosphorus are always present. Nitrogen-phosphorus (N:P) ratios fluctuate widely. During summer, vertical mixing provides nutrients to the euphotic zone where there is enough light to permit growth of green plants. In deep offshore waters of an area just east, of the Bight, the $N: P$ ratio was about $12: 1$ with low seasonal variation at the oxygenmaximum-nutirent-maximum layer (Horne et a1, 1971, Ketchum et al, 1958). In the dump areas, concentrations are expected to be different. Sewer sludges disposed in the area are rich in certain nutrients.

Concentrations of phosphorus (ortho, organic meta and total), nitrate, and chlorophy11-a, within this area, were determined in the Bight by SHL. Phosphorus, an essential nutrient in aquatic food chains, is abundant in the sludges, and can serve as a tracer in following the movement of contaminated water. As expected, the concentration of phosphorus was higher in the dump area. SHL found concentrations of orthophosphorus up to 5.64 microgram-atom per liter $(\mu g-a t / 1)$, while reference leve1s, outside the dumping grounds, ranged from 0.2-0.9 $\mu \mathrm{g}-\mathrm{at} / 1$.

Nitrogen, as reflected by $\mathrm{N}: \mathrm{P}$ ratios, and chlorophyll-a concentrations, are greatly affected by phosphorus concentrations. In the oceans, phytoplankton utilize both phosphates and nitrates and since the content of 

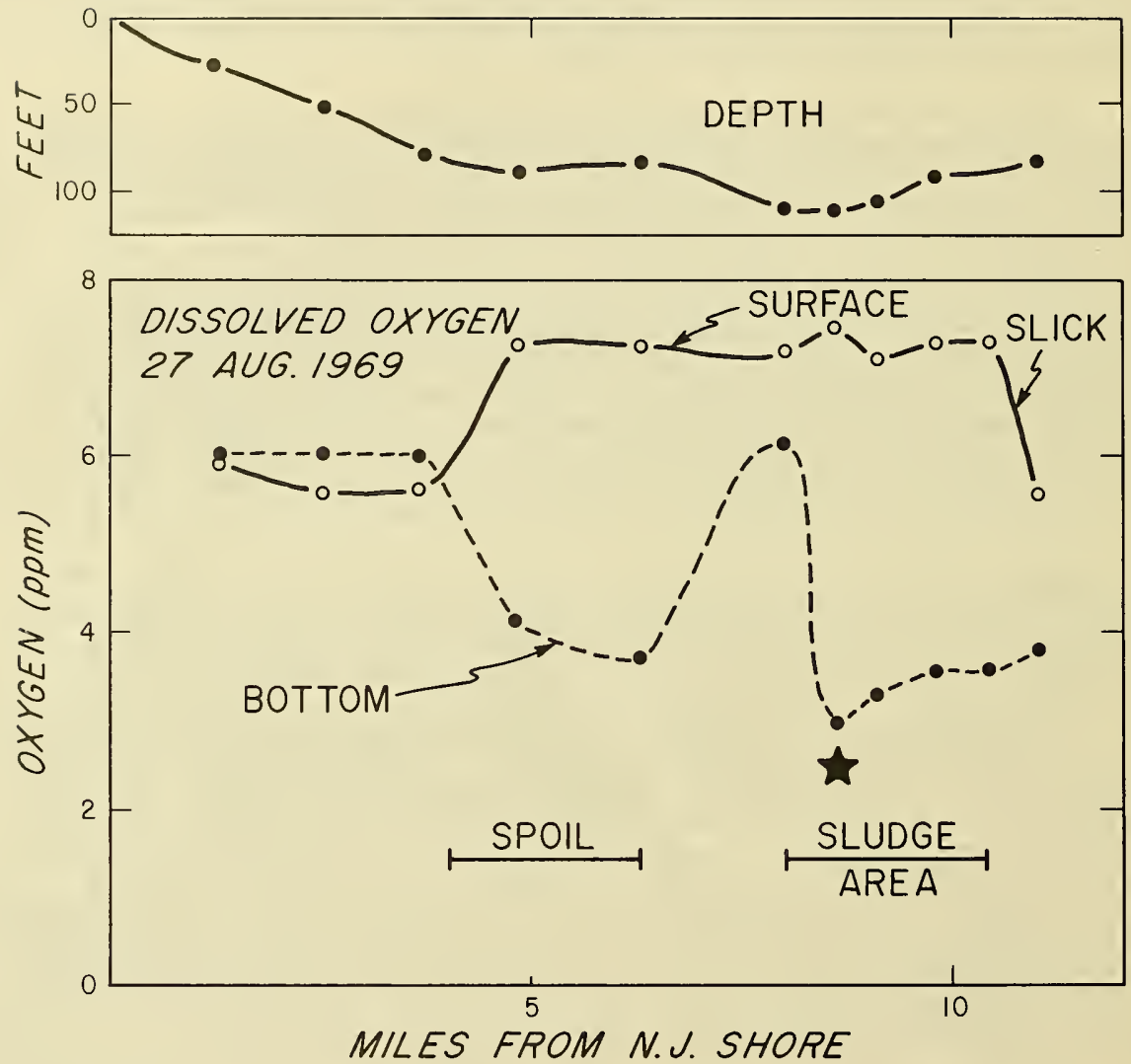

Figure 22. Dissolved Oxygen Content of Surface Water and Water 3 Feet off the Bottom in a Section Extending Seaward from the Coast of New Jersey (After Ketchum, et al., 1970) 
these two nutrients varies in the same way, the $N: P$ ratios remain fairly constant, with a few exceptions. Nitrate is usually the limiting nutrient.

Near the dumping grounds, N:P ratios were considerably lower on the average than elsewhere in the Bight, ranging from 0 to 14.42 for surface waters, and from 0 to 7.70 for bottom waters. The low N:P ratios cannot be attributed to low nitrate concentrations, but to high phosphate concentrations. In fact SHL found nitrate concentrations of up to 3.25 $\mu \mathrm{g}-\mathrm{at} / 1$. Chlorophyll-a ranged from 0.38 to $33.3 \mathrm{ug-at} / 1$. This ranges of nutrient concentration found in the Bight are summarized in Table 5. The effects of nutrients on water and sediment characteristics of the dumping grounds are discussed at another section of this report.

d. Heavy Metals. Sewage sludges, dredge spoils, and other waste materials dumped in the ocean contain many substances, including heavy metals. Tables 6 and 7 show the major and minor elements found in the sewage sludges destined for the Bight dumping grounds (Gross, 1970). Table 7 , shows the concentrations of these elements in sewage sludges as determined by spectrochemical analysis and the origin of some of these waste materials in the New York area.

Sewage sludges and polluted dredge spoils from other heavily industrialized regions also contain certain heavy metals in high concentrations. The concentration ranges of such heavy metals are shown in Table 8 (Train, Cahn, and MacDonald, 1970). Table 9 summarizes relative quantities of certain potentially troublesome elements in wastes originating from the New York Metropolitan Region. These concentrations were determined by the SUNY-SB study (Gross, 1970). Particularly noteworthy are the relatively high concentrations of lead, chromium, copper, zinc, and silver. The median concentration values of these metals in wastes and sediments from different locations are summarized in Fig. 23.

Gross (1971) investigated the distribution of samples containing anomalously high total concentrations of heavy metals and compared this distribution to the distribution of carbon-rich deposits on the Continental Shelf of the Bight. Heavy metals were analyzed by emission spectroscopy. Total lead concentrations in the waste deposits were over 10 times higher than the average lead content of marine organisms or shale. The distributions of the heavy metals, copper, chromium, lead, and silver of the sediments of the dumping grounds are shown in Figures 24 through 27. Other acid-extractable minor elements in wastes and waste deposits were determined by the SUNY using optical emission spectrochemical analysis. On the average, about 1 percent of the total metal concentration was extractable by hydrochloric acid ( $\mathrm{HCl}$ ) except nickel (about five percent was extracted). A high correlation was found between total and extractable concentrations of copper, chromium, and iron, suggesting that these elements are well dispersed in the samples and generally occur in chemical states little affected by $\mathrm{HCl}$ treatment. No apparent correlation was determined between acid-extractable and total tin concentrations. Correlation between extractable and total lead concentrations was relatively poor. The study concluded that because of the low 
Table 6. Abundance of Major Elements in Typical Sewage Sludge and Natural Sediments.

\begin{tabular}{|c|c|c|c|c|c|c|}
\hline \multicolumn{5}{|c|}{ Sewage Sludges } & \multicolumn{2}{|c|}{ Sedimentary Rocks } \\
\hline & $\begin{array}{l}\text { lement } \\
\text { (percent) }\end{array}$ & & $\begin{array}{l}\text { ides } \\
\text { (percent) }\end{array}$ & $\begin{array}{c}\text { Carbon-free* } \\
\text { (percent) }\end{array}$ & $\begin{array}{c}\text { Shalc } \\
\text { (percent) }\end{array}$ & $\begin{array}{r}\text { Sandstone } \\
\text { (percent) }\end{array}$ \\
\hline $\mathrm{Si}$ & 10.0 & $\mathrm{SiO}_{2}$ & 21.4 & 63.6 & 58.1 & 78.3 \\
\hline $\mathrm{Ti}$ & 0.25 & $\mathrm{TiO}_{2}$ & 0.4 & 1.2 & 0.65 & 0.25 \\
\hline A] & 2.5 & $\mathrm{~A}_{2} \mathrm{O}_{3}$ & 4.8 & 14.3 & 15.4 & 4.8 \\
\hline $\mathrm{Fe}$ & 1.3 & $\mathrm{Fe} 0$ & 1.7 & 5.0 & 6.1 & 1.3 \\
\hline $\mathrm{Mg}$ & 0.6 & Mg0 & 1.0 & 3.0 & 2.4 & 1.2 \\
\hline $\mathrm{Ca}$ & 1.5 & $\mathrm{CaO}$ & 2.1 & 6.2 & 3.1 & 5.5 \\
\hline $\mathrm{Na}$ & 0.75 & $\mathrm{Na}_{2} 0$ & 1.0 & 3.0 & 1.3 & 0.45 \\
\hline K & 1.0 & $\mathrm{~K}_{2} \mathrm{O}$ & 1.2 & 3.6 & 3.2 & 1.3 \\
\hline $\mathrm{C}$ & 31.0 & Organic & 56.0 & -- & 0.80 & ---- \\
\hline $\mathrm{P}$ & 0.55 & $\mathrm{P}_{2} 0_{5}$ & 1.2 & -- & 0.17 & 0.08 \\
\hline
\end{tabular}

* Chemical composition recalculated, and adjusted to after Gross, 1970 100 percent after subtracting carbon and phosphorus content. 
Table 7. Spectrochemical Analyses of Sewage Sludges in the New York Metropolitan Region

\begin{tabular}{|c|c|c|c|c|c|}
\hline Element & $\begin{array}{c}\text { Wards Island } \\
\text { (percent) }\end{array}$ & $\begin{array}{c}\text { Hunts Point } \\
\text { (percent) }\end{array}$ & $\begin{array}{c}\text { Newtown Creck } \\
\text { (percent) }\end{array}$ & $\begin{array}{c}\text { Bowery Bay } \\
\text { (percent) }\end{array}$ & $\begin{array}{l}\text { Tallsmans Island } \\
\text { (percent) }\end{array}$ \\
\hline Silicon & 7.0 & 8.9 & 11.0 & 10.0 & 10.0 \\
\hline Iron & 1.0 & 2.6 & 1.2 & $3.2 \dagger$ & 1.5 \\
\hline Aluminum & 1.7 & 2.5 & 2.5 & 2.7 & 2.7 \\
\hline Calcium & 1.2 & 1.8 & 3.7 & 1.6 & 1.4 \\
\hline Magnesium & 0.63 & 0.69 & 0.59 & $0.84 \dagger$ & 0.80 \\
\hline Copper & 0.056 & 0.14 & 0.16 & 0.19 & 0.11 \\
\hline Sodium & $2.0 \dagger$ & 1.2 & 1.3 & 1.7 & 1.1 \\
\hline Titanium & 0.17 & 0.38 & 0.23 & $0.56 \dagger$ & 0.27 \\
\hline Chromium & 0.050 & 0.11 & 0.080 & 0.25 & 0.085 \\
\hline Potassium & 2.5 & $2.7 t$ & 1.7 & 2.7 & 1.8 \\
\hline Phosphorus & 0.29 & 0.91 & 0.65 & 0.77 & 0.70 \\
\hline Barium & $0.040 \dagger$ & 0.059 & $0.10 t$ & 0.071 & 0.042 \\
\hline Boron & 0.0016 & 0.0024 & 0.0034 & 0.0020 & 0.0034 \\
\hline Lead & $\mathrm{TR}<0.005$ & 0.055 & $0.12 t$ & 0.12 & 0.056 \\
\hline Manganese & 0.014 & 0.017 & 0.021 & 0.029 & 0.040 \\
\hline Nickel & 0.0069 & 0.019 & 0.025 & $0.090 \dagger$ & 0.033 \\
\hline Molybdenum & 0.0011 & 0.0016 & 0.0033 & 0.0039 & TR 0.002 \\
\hline Tin & 0.021 & 0.034 & 0.028 & 0.048 & 0.022 \\
\hline Vanadium & 0.0076 & $0.015 t$ & 0.0059 & 0.011 & 0.0080 \\
\hline Bismuth & $\mathrm{ND}<0.002$ & -- & $\mathrm{TR}<0.002$ & $\mathrm{ND}<0.002$ & ----- \\
\hline Silver & 0.0015 & 0.0014 & 0.0016 & $0.0033 t$ & 0.0021 \\
\hline Zinc & $0.069 \dagger$ & 0.25 & 0.24 & $0.29 \dagger$ & 0.17 \\
\hline Zirconium & 0.0053 & 0.012 & 0.027 & $0.021 \dagger$ & 0.012 \\
\hline Cobalt & 0.0015 & 0.0036 & 0.0039 & $0.0061 \dagger$ & 0.0031 \\
\hline Strontium & 0.0096 & 0.015 & 0.0097 & $0.015 \dagger$ & 0.0075 \\
\hline Arsenic & $\mathrm{ND}<0.06$ & --- & $--\cdots--$ & ------ & ---- \\
\hline Mercury & $\mathrm{ND}<0.09$ & --- & $-----\cdots$ & $-\cdots----$ & ----- \\
\hline Antimony & $\mathrm{ND}<0.008$ & --- & $---\cdots$ & $---\cdots--$ & ----- \\
\hline Thorium & $\mathrm{ND}<0.10$ & $-\cdots$ & $----\cdots$ & ------- & ----- \\
\hline Beryllium & $\mathrm{ND}<0.0003$ & --- & ------ & ------ & ----- \\
\hline Gallium & $\mathrm{ND}<0.003$ & --- & ----- & $-----\cdots$ & ---- \\
\hline Yttrium & $\mathrm{ND}<0.009$ & --- & ------ & ------- & ----- \\
\hline Ytterbium & $\mathrm{ND}<0.004$ & --- & ------ & ------- & ----- \\
\hline Cerium & $\mathrm{ND}<0.04$ & --- & ----- & ------- & ----- \\
\hline $\begin{array}{c}\text { Other } \\
\text { Loss on Ignition } \\
\text { (sulfate ash) }\end{array}$ & $\begin{array}{c}\text { nil } \\
64.55\end{array}$ & $\begin{array}{c}\text { nil } \\
53.75\end{array}$ & $\begin{array}{c}\text { nil } \\
49.10\end{array}$ & $\begin{array}{c}\text { nil } \\
47.90\end{array}$ & $\begin{array}{c}\text { nil } \\
55.40\end{array}$ \\
\hline
\end{tabular}

ND Not Detected

after Gross, 1970

TR Trace

$\dagger$ Maximum value for element 
Table 8. Heavy Metals Concentrations in Sewage Sludge and Dredge Spoils

\begin{tabular}{|c|c|c|c|c|c|}
\hline Metal & $\begin{array}{c}\mathrm{Sev} \\
(\mathrm{min})\end{array}$ & $\begin{array}{l}\text { age Sluc } \\
\text { (avg) }\end{array}$ & $\begin{array}{l}\operatorname{lgc} \\
(\max ) \\
(\mathrm{ppm})\end{array}$ & $\begin{array}{c}\text { Natural in Sea Water } \\
(\mathrm{ppm})\end{array}$ & $\begin{array}{l}\text { Toxic to Marine Water } \\
\text { (ppm) }\end{array}$ \\
\hline Copper & 315 & 643 & 1,980 & 0.003 & 0.1 \\
\hline Zinc & 1,350 & 2,459 & 3,700 & 0.01 & 10.0 \\
\hline Manganese & 30 & 262 & 790 & 0.002 & $\ldots$ \\
\hline & \multicolumn{3}{|c|}{ Dredge Spoils } & & \\
\hline Cadmuim & \multicolumn{3}{|c|}{130} & 0.08 & 0.01 to 10.0 \\
\hline Chromium & \multicolumn{3}{|c|}{150} & 0.0005 & 1.0 \\
\hline Lead & \multicolumn{3}{|c|}{310} & 0.00003 & 0.1 \\
\hline Nickel & \multicolumn{3}{|c|}{610} & 0.0054 & 0.1 \\
\hline
\end{tabular}

after Train, Cahn, and MacDonald, 1970 
Table 9. Estimated Amounts of Oxidizable Carbon and Potentially Troublesome Elements Discharged with Solids in Offshore Dumps, New York Metropolitan Region.

\begin{tabular}{|l||c||c|c|c|c|c|c|}
\hline \multicolumn{7}{|c|}{ Annual Discharge* } & \\
\hline Type of Waste Solid & Solids & Oxidizable Carbon & \multicolumn{4}{|c|}{ Minor Elements } & \\
\hline Dredged Wastes $\dagger$ & $35 \times 10^{11}$ & $6 \times 10^{10}$ & $5 \times 10^{7}$ & $1.4 \times 10^{9}$ & $7 \times 10^{8}$ & $2 \times 10^{8}$ & $2 \times 10^{9}$ \\
Sewage Sludge $\ddagger$ & $2 \times 10^{11}$ & $4 \times 10^{10}$ & $2 \times 10^{6}$ & $2 \times 10^{8}$ & $2 \times 10^{8}$ & $6 \times 10^{7}$ & $10^{8}$ \\
Fly Ash & $10^{11}$ & $3 \times 10^{9}$ & $<10^{5}$ & $2 \times 10^{7}$ & $10^{7}$ & $<2 \times 10^{6}$ & $3 \times 10^{7}$ \\
\hline
\end{tabular}

after Gross, 1970

* Discharges expressed in grams per year $\left(10^{6}\right.$ grams equals one metric ton).

$\dagger$ Oxidizable carbon discharges calculated from observed carbon concentrations in harbor sediment, corrected for carbon losses during dredging operations.

$\ddagger$ Oxidizable carbon 20 percent by weight. 


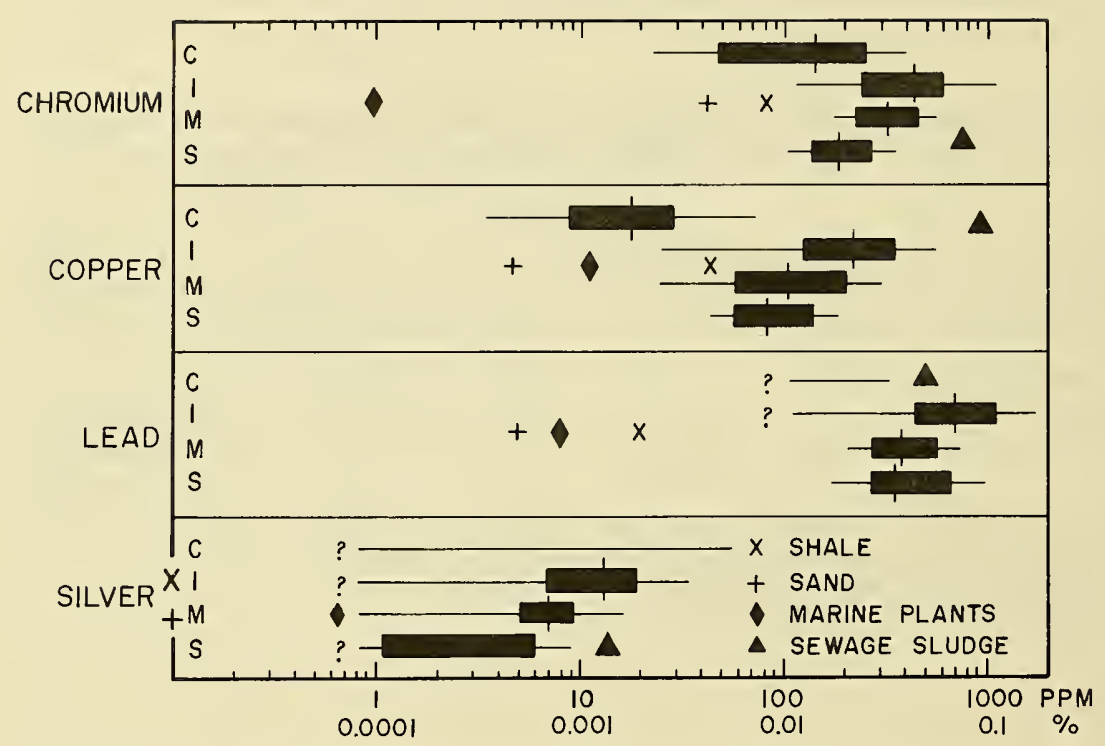

Figure 23. Median concentration value (indicated by vertical line) range, and limits for 70 percent of samples analyzed (shown by heavy bar) for surficial samples in New York Harbor and New York Bight. (C-continental shelf sediment, I-inner harbor deposits, M-deposits near "mud" disposal area, S-deposits near sewage sludge disposal area). Typical concentrations are shown for shales, sands, and marine plants (Bowen, 1966) and sewage sludges. Question marks indicate the detection limits for the various elements (After Gross, 1970) 


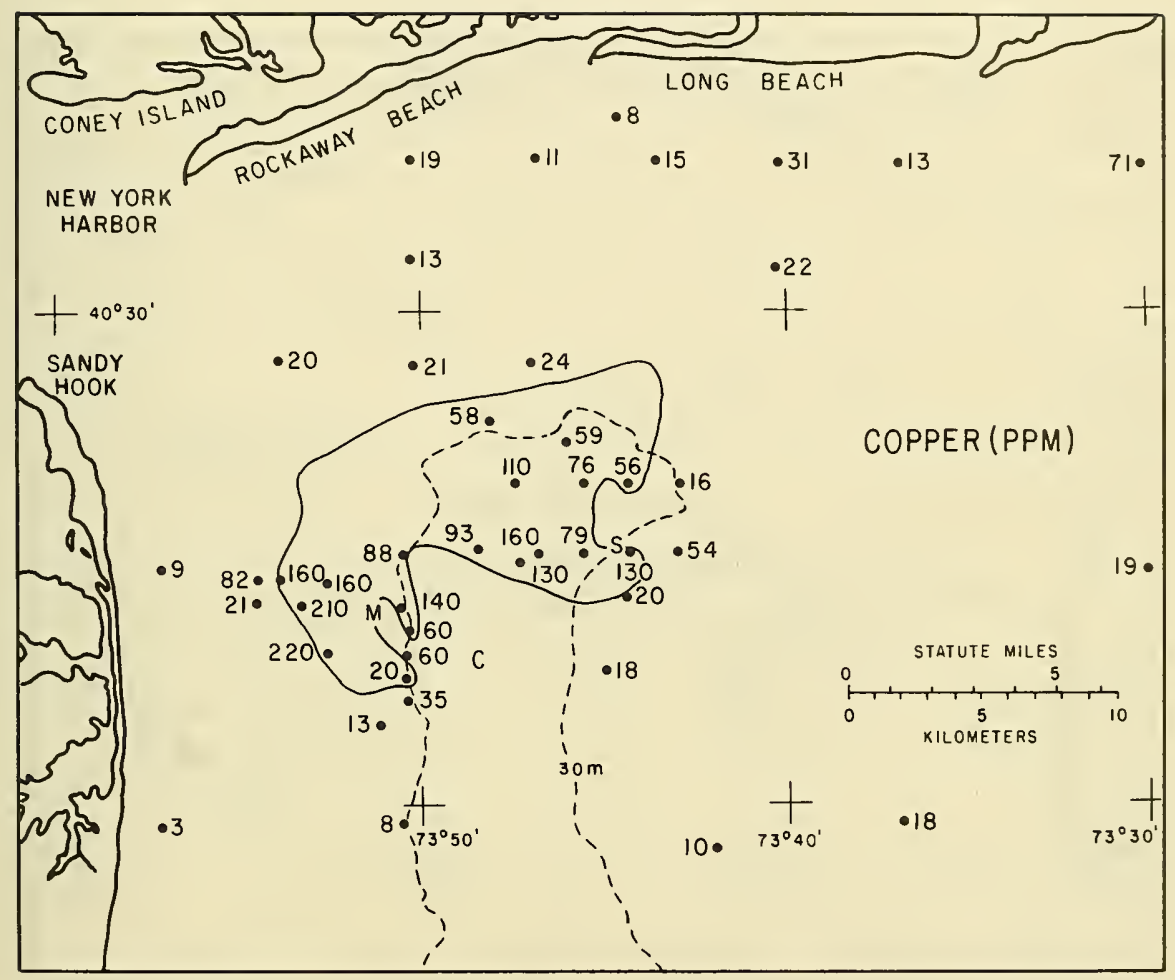

Figure 24. Distribution of total copper concentrations in surficial sediment and waste deposits in the New York Bight as determined by SUNY-SB (After Gross, et a1, 1971) 


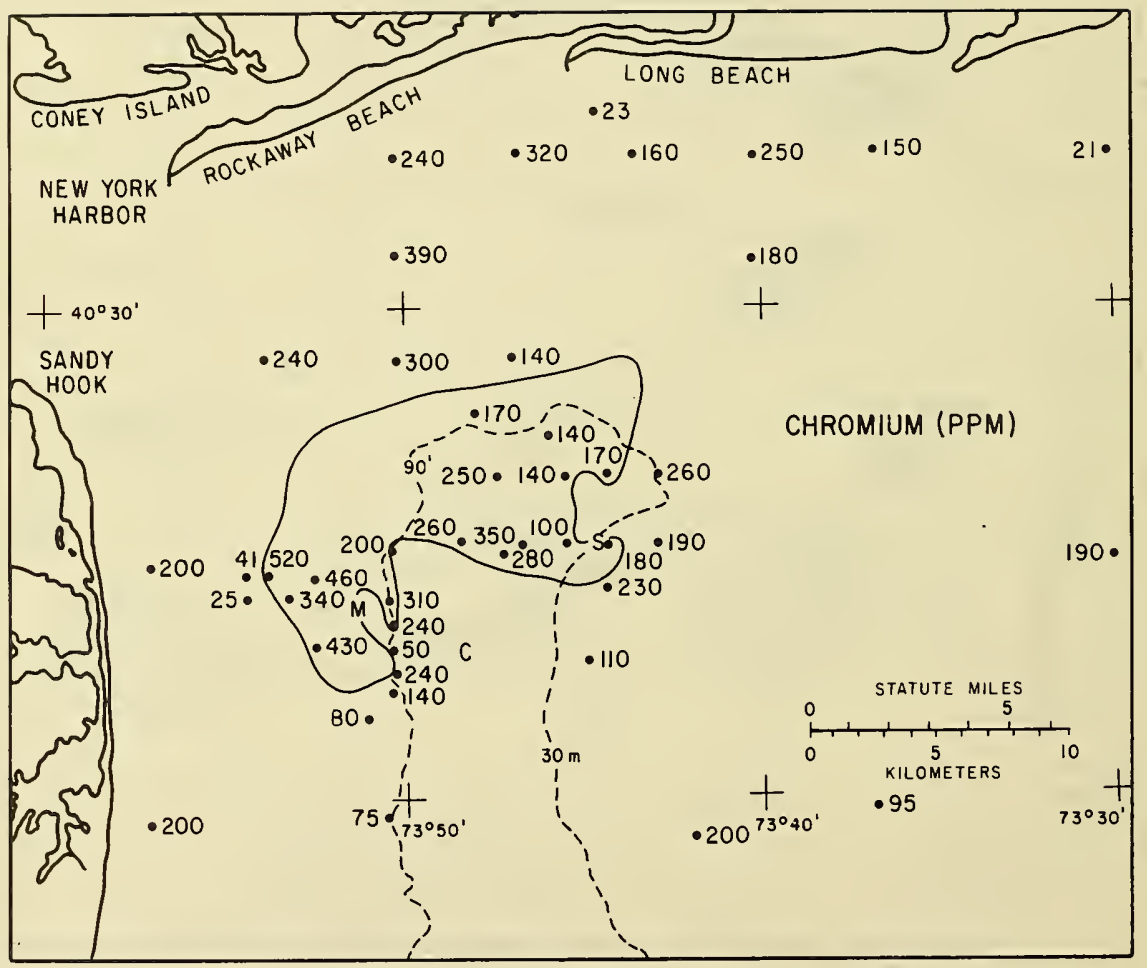

Figure 25. Distribution of Total Chromium Concentrations in Surficial Sediments and waste deposits in New York Bight as determined by SUNY-SB. (The heavy contour outlines the area containing deposits with more than one percent total carbon.) (After Gross, et a1, 1971) 


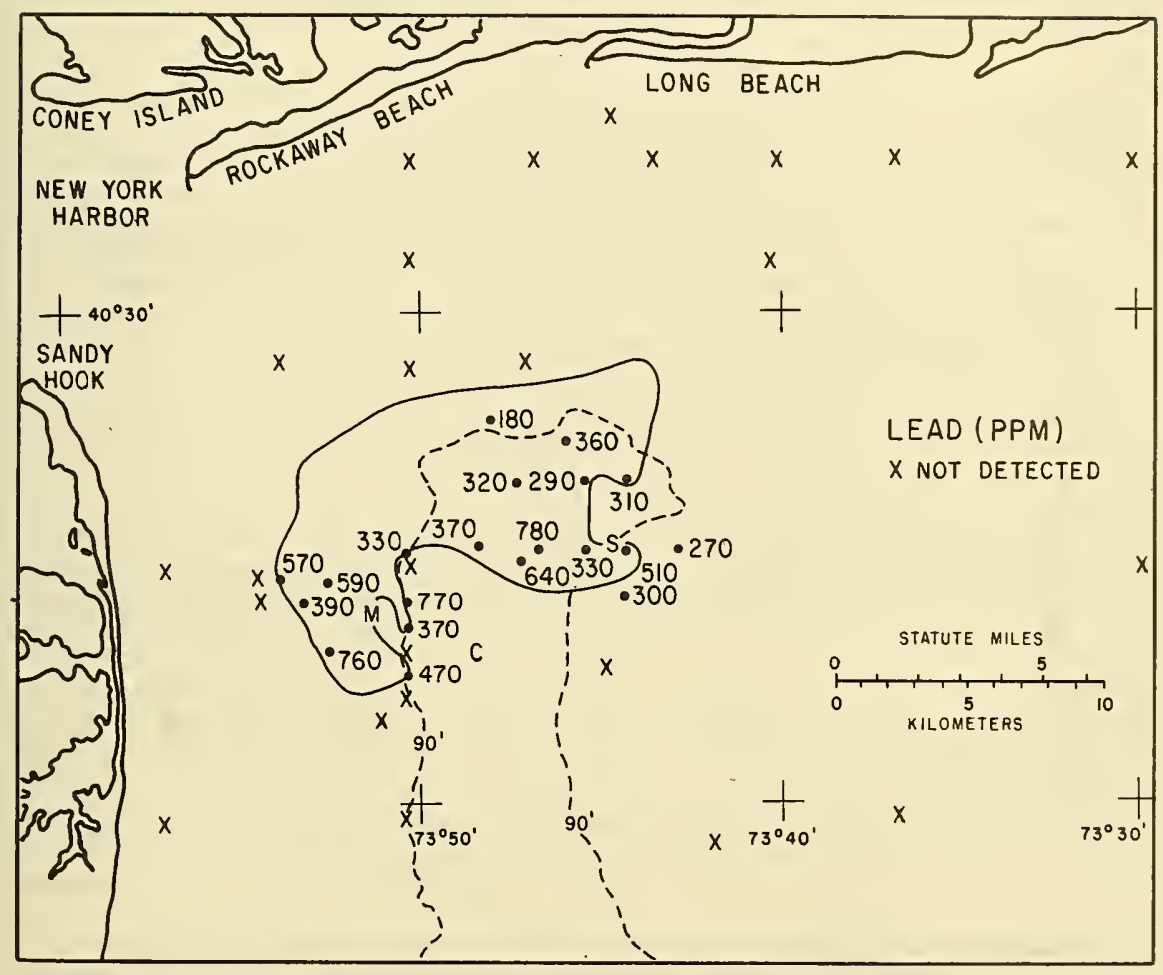

Figure 26. Distribution of total lead concentrations in Surficial - Sediment and waste deposits in the New York Bight, determined by SUNY-SB. (After Gross, et a1, 1971) 


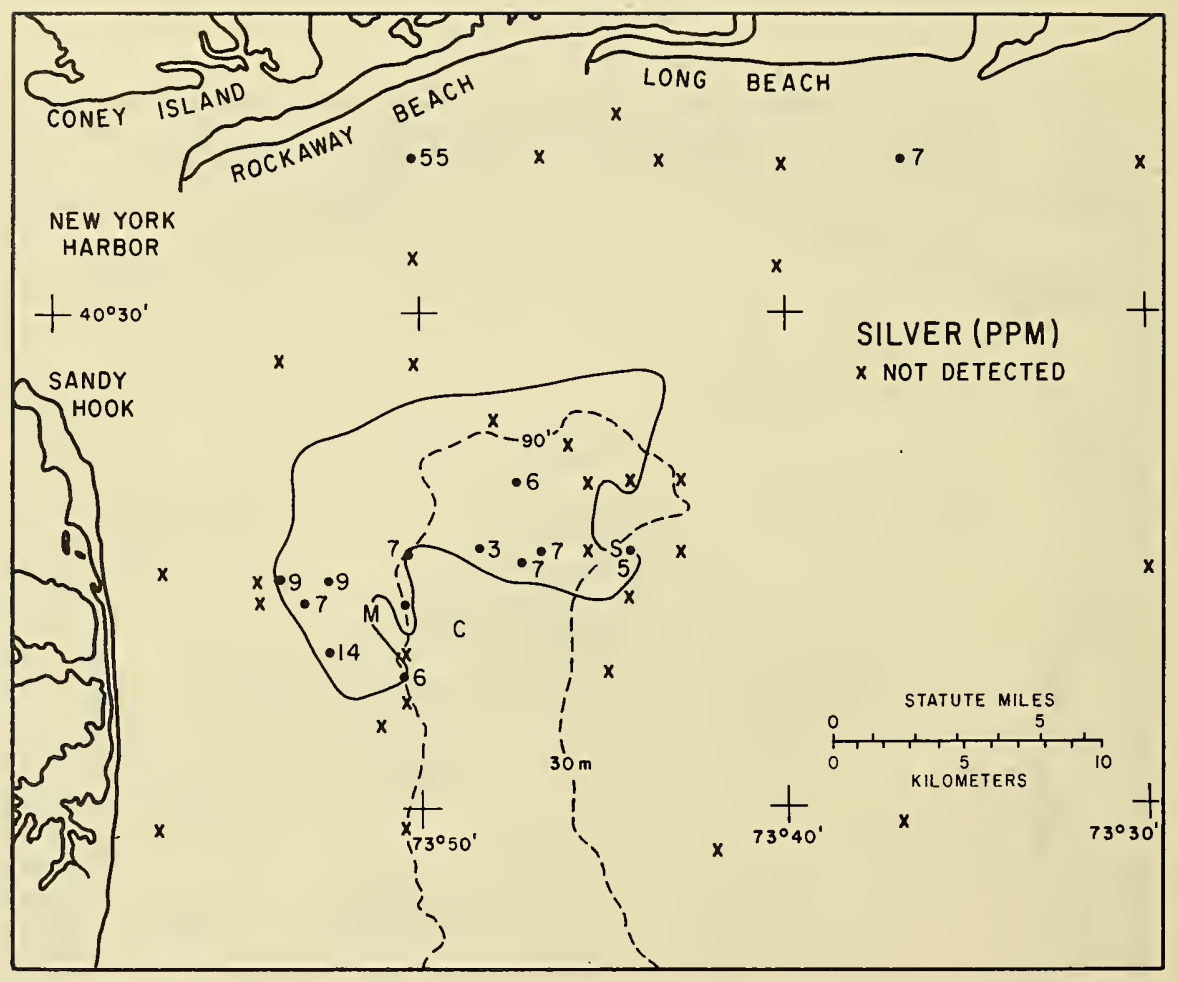

Figure 27. Distribution of total silver concentrations in Surficial Sediment and waste deposits in the New York Bight (After Gross et a1. 1971) 
extraction efficiency with hot hydrochloric acid, the various metals studied (except lead), will not migrate easily from the waste deposits to the overlying water. Lead and copper were found to be the most useful elements for delineating the distribution of wastes.

Limited surveys of heavy metals in sediment samples from the Bight were also made by SHL (1972) in conjunction with zooplankton investigations, but were later expanded. Heavy metal analyses were also made on a few plankton and animal samples collected in and around the disposal areas.

The distribution of heavy metals in the sediments, such as copper, chromium, lead, nickel and zinc, as determined by the SHL, covers an area larger than the dumping grounds. (Fig. 28, 29, 30, 31, 32). Heavy metal content of the sediments in and around the dumping grounds was significantly increased as compared to nonpolluted sediments, and as previously determined by the SUNY study (Gross, 1971). Discrepancies in the ranges of heavy metal concentrations, as determined by SHL and SUNY, even though within the same general area, are attributed primarily to differences in points of sampling, which indicate geographic variation, and to a lesser extent to differences in analytical techniques. High values of heavy metals in the sediments, (SHL, 1972) along the upper part of the Hudson Canyon, south of the dumping grounds, indicate that a transport mechanism is in operation.

Analysis for heavy metals in organisms, by SHL, showed that some specimens contained concentrations of lead, chromium and mercury that were above the normal range for marine animals. These metals were also found in the water in higher concentrations (SHL, 1972).

e. Organic Fraction. Sewer sludges, from treatment plants in New York City and New Jersey, dumped in the Bight, are rich in organic material (Table 10). Total loss-on-ignition ranges from about 46 to 80 percent of the dry weight of the material. Oxidizable carbon content ranges from 18 to 26 percent. The remaining non-organic fraction of the sludges is composed of aluminosilicate materials which are chemically similar to shale (Gross, 1970).

A large percentage of the organic fraction of sewage sludge dumped in the N.Y. Bight is composed of water soluble acids and sugars. (Gluturic acid, glycolic acid, lactic acid, citric acid, benzoic acid, phenyl lactic, glucose, sucrose, lactose, etc.) (Walter, 1961). Another large fraction of organic material is relatively insoluble, and will remain in suspension or will be included in the bottom sediments until final decomposition. This group may contain proteins, certain carbohydrates, fats, esters, and unidentified organic components. The percent total carbon composition of suspended solid material in sewage is shown in Table 11 .

The material dredged from the New York harbor and disposed at the dredge dumping grounds consists primarily of silicate material, and 


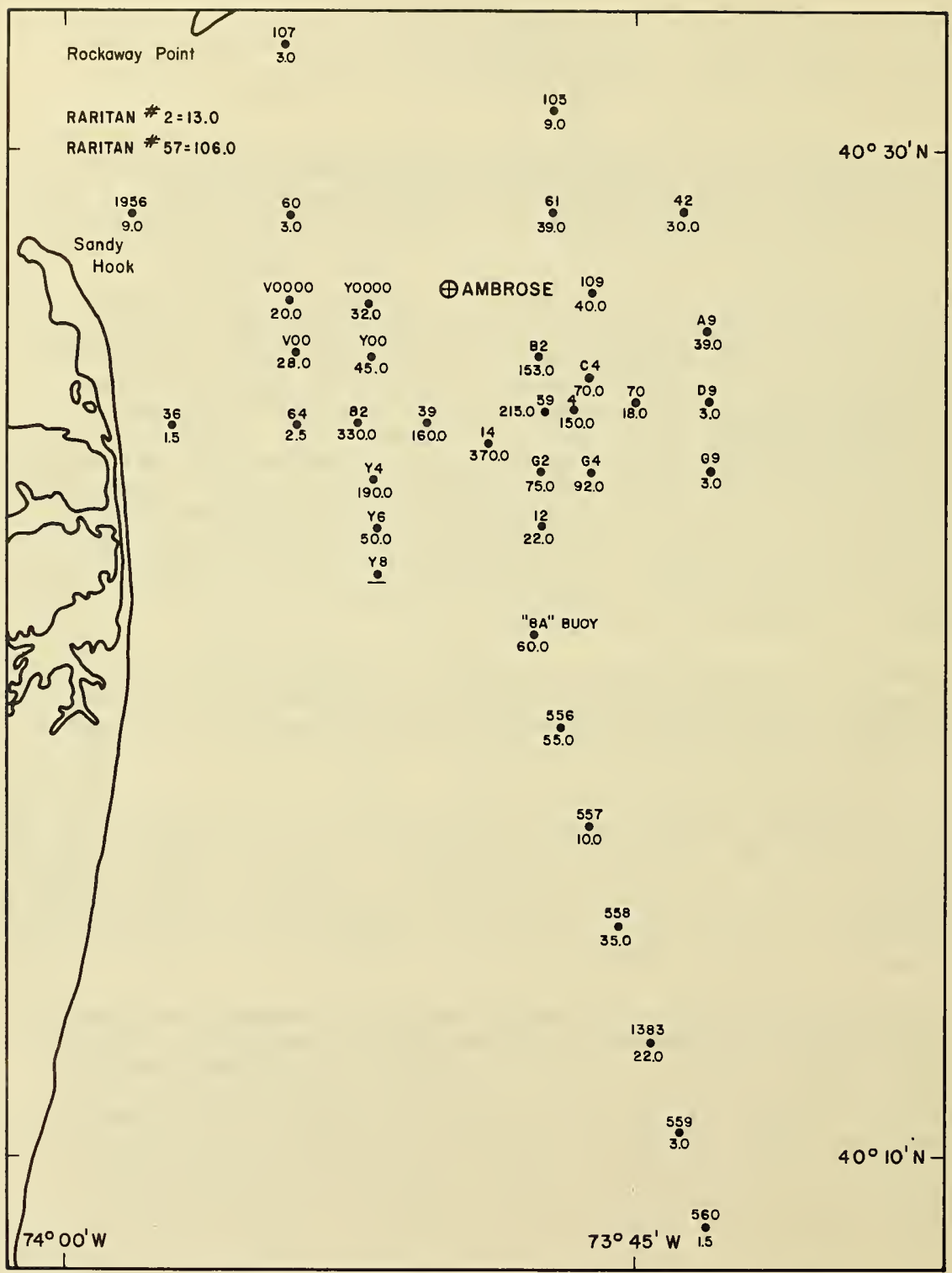

Figure 28. Total Comper as ppm of Dry Sediment through November 1971 (After SHL, 1972) 


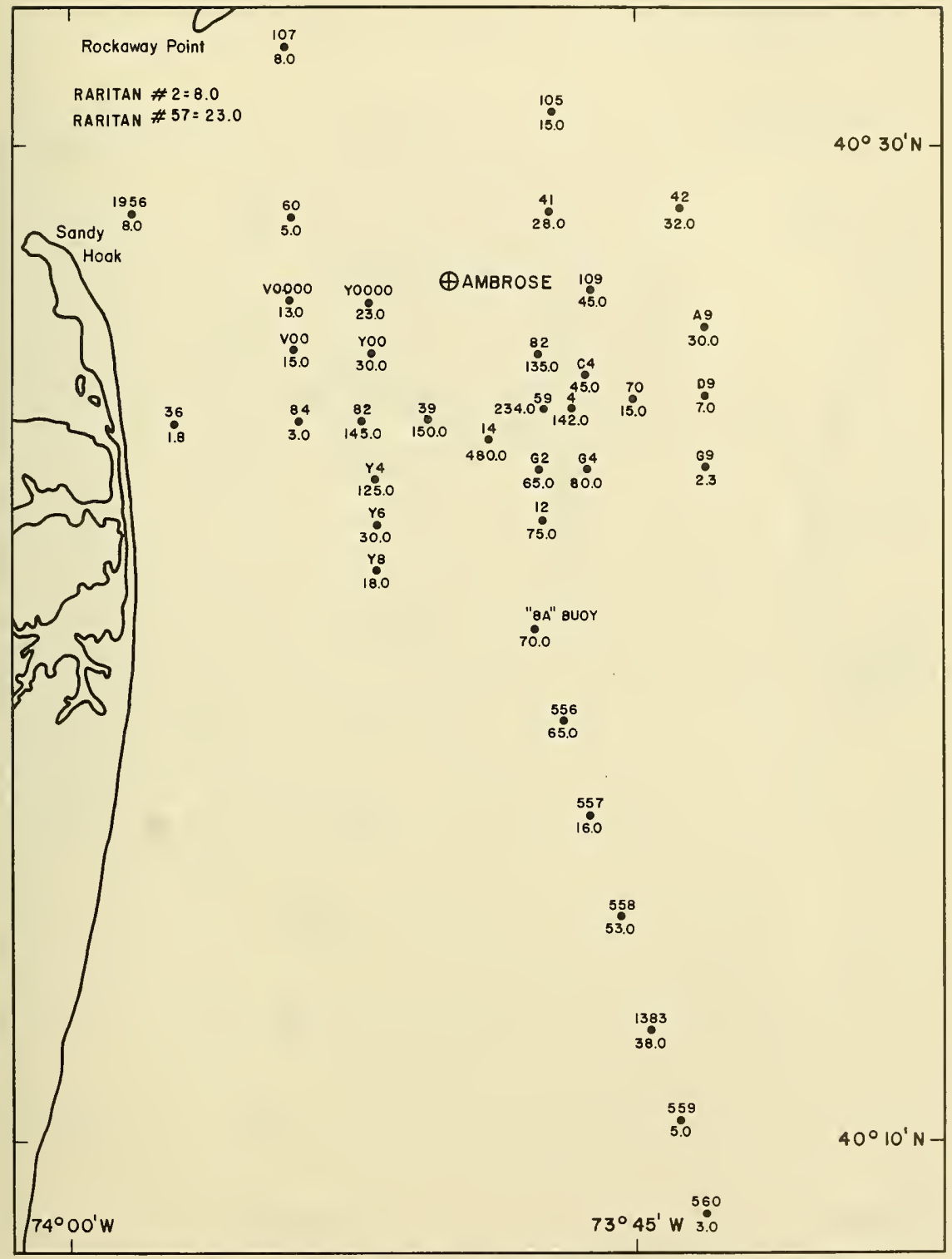

Figure 29. Total Chromium as ppm of Dry Sediment through November 1971 (After SHL, 1972) 


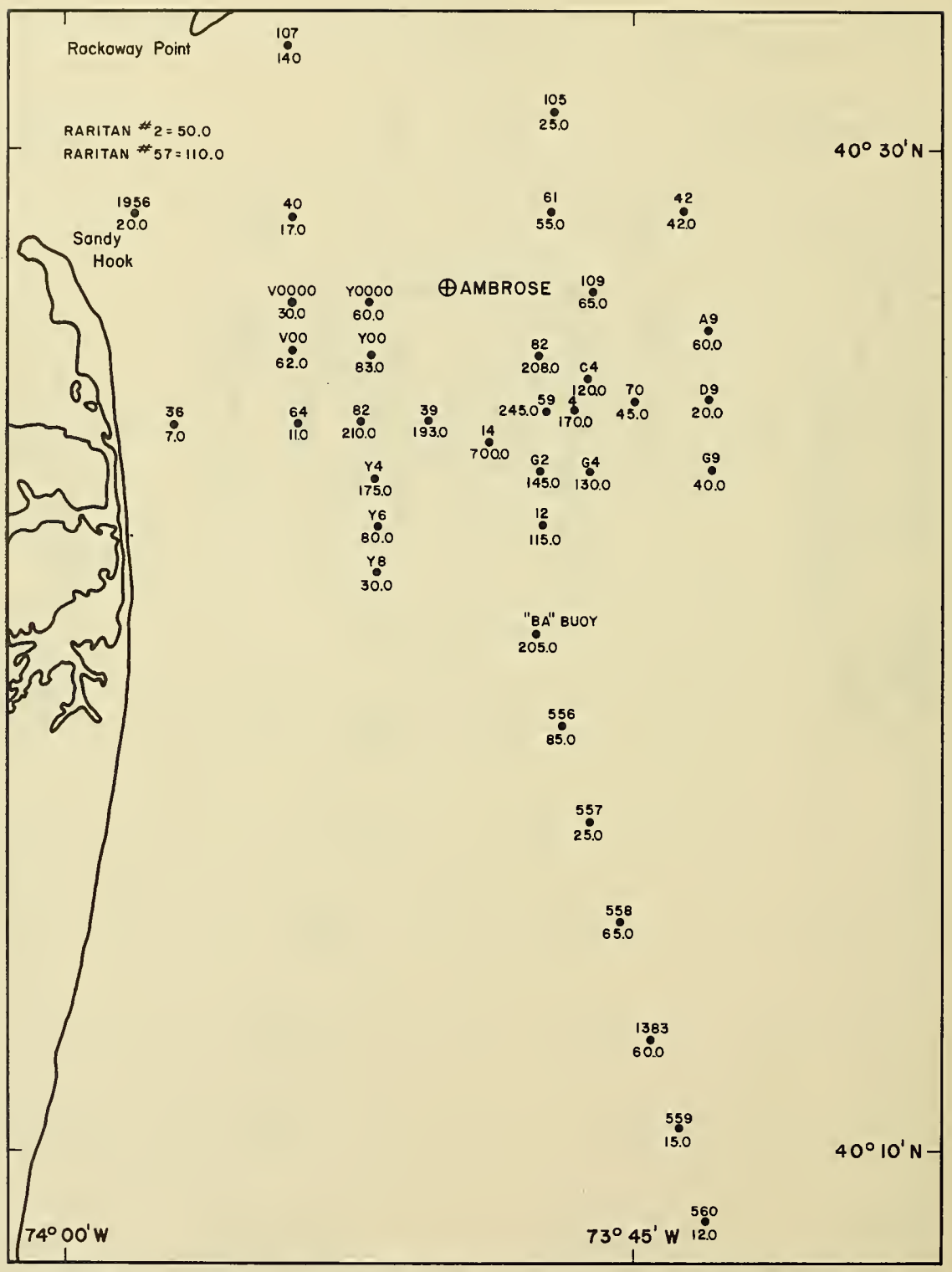

Figure 30. Total Lead as ppm of Dry Sediment through November 1971 (After SHL, 1972) 


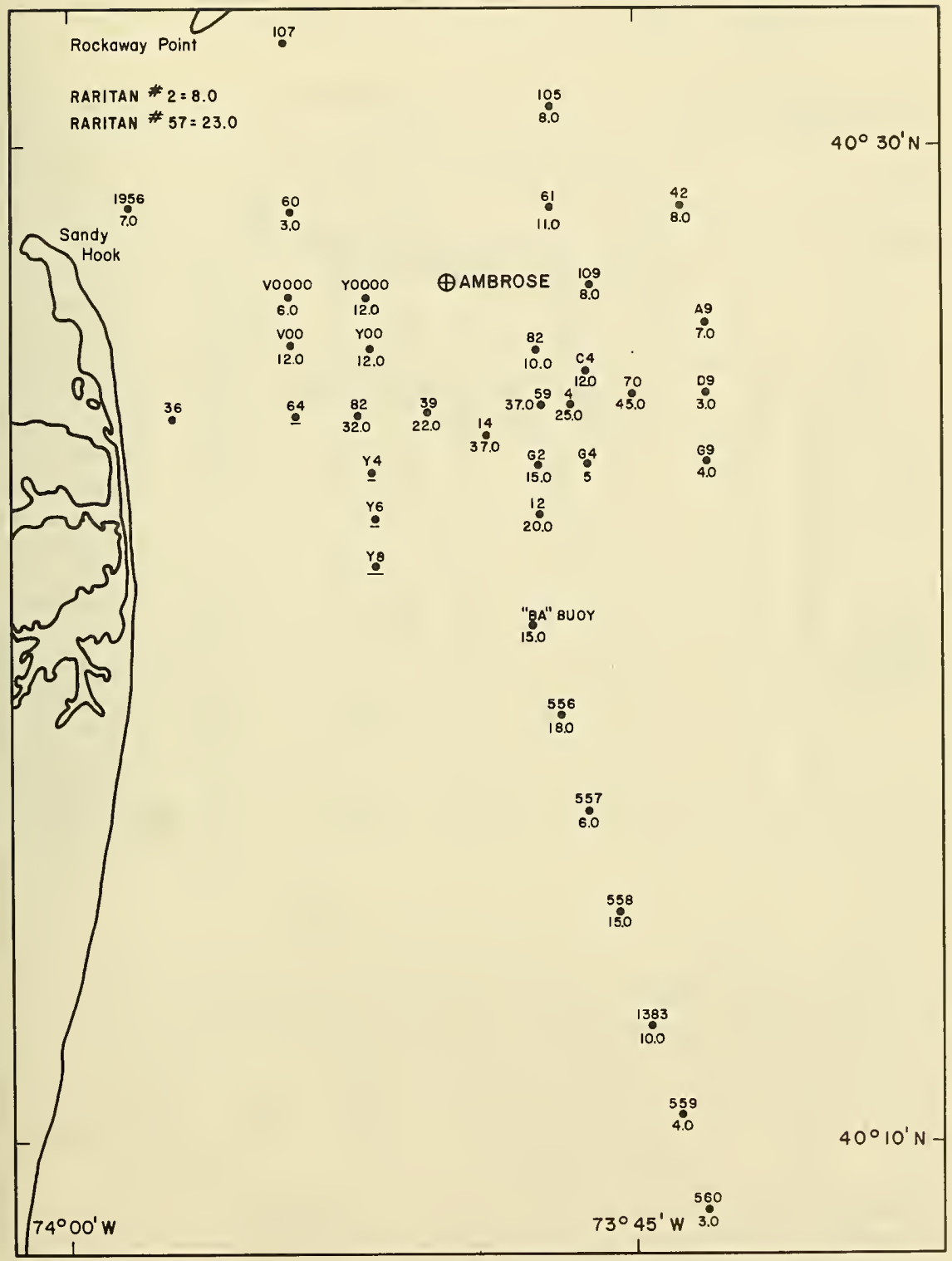

Figure 31. Total Nickel as ppm of Dry Sediment through November 1971 (After SHL, 1972) 


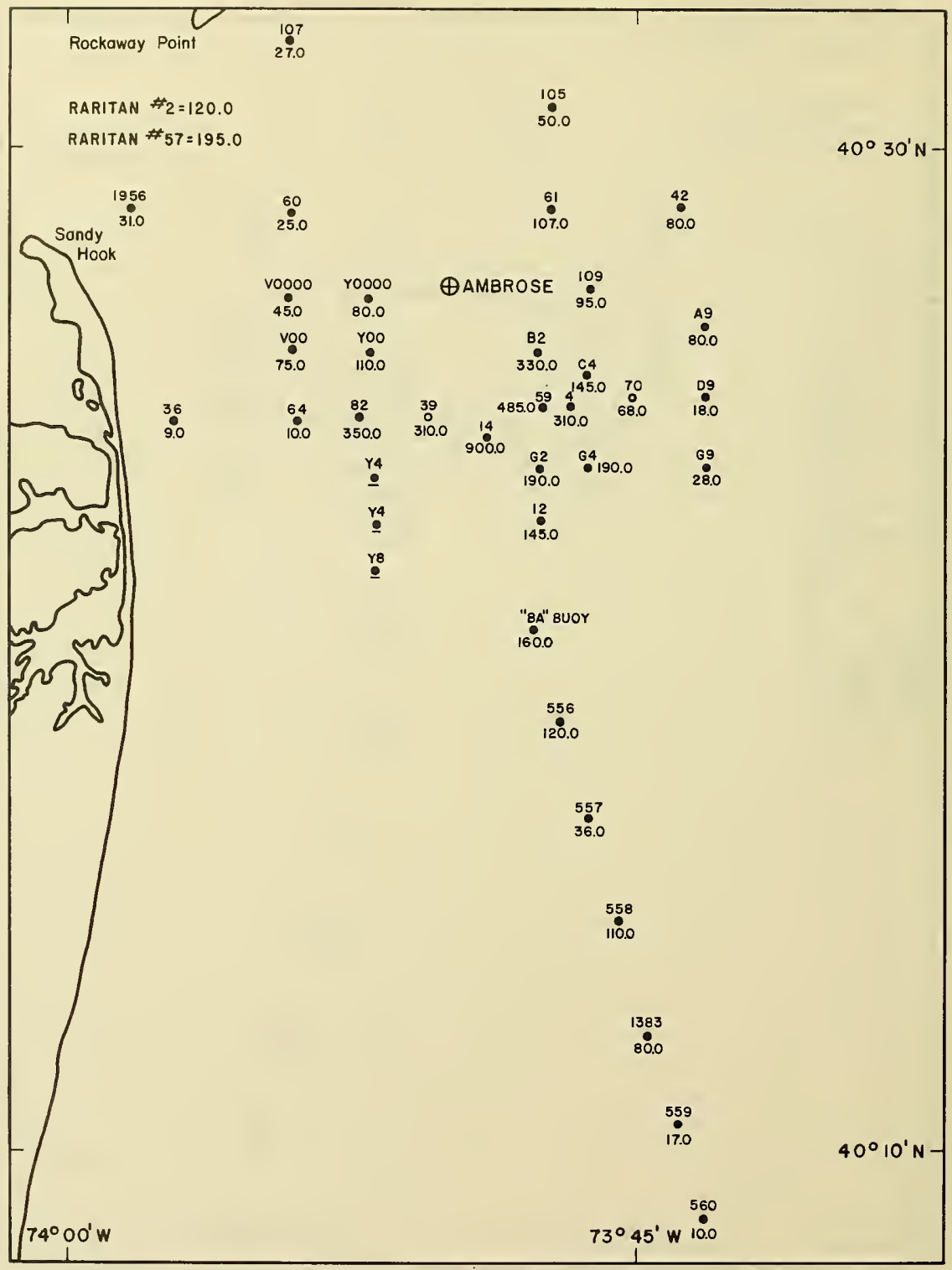

Figure 32. Total Zinc as ppm of Dry Sediment through November 1971 (After SHL, 1972) 
Table 10. Some Chemical Properties of Sewage Sluges in the New York Metropoltian Region

\begin{tabular}{|c||c|c|c|c||c|c|}
\hline \multirow{2}{*}{$\begin{array}{c}\text { Sample } \\
\text { Number }\end{array}$} & \multicolumn{5}{c|}{ Carbon } & \\
& Total & Carbonate & \multicolumn{2}{c|}{ Oxidizable Carbon } & $\begin{array}{r}\text { Reducing } \\
\text { Capacity } \\
\text { (MEQ/g) }\end{array}$ & Sulfide \\
& (percent) & (percent) & (percent) & (MEQ/g) & \\
\hline \hline 090818001 & 34.4 & 0.5 & 21.8 & 72.7 & 131.2 & 0.1 \\
090818002 & 31.8 & 0.0 & 23.5 & 78.3 & 118.2 & 0.3 \\
690818003 & 30.8 & 1.5 & 20.9 & 69.7 & 114.1 & 0.4 \\
690818004 & 28.5 & 0.0 & 18.3 & 61.0 & 110.2 & 0.2 \\
690918005 & 28.4 & 0.3 & 20.9 & 69.7 & 110.1 & 0.2 \\
690819001 & 25.4 & 0.3 & 18.1 & 60.3 & 123.8 & 0.3 \\
690819003 & 29.6 & 0.2 & 21.1 & 70.3 & 127.9 & 0.3 \\
690819004 & 27.8 & 0.1 & 20.3 & 67.7 & 106.3 & 0.3 \\
690819005 & 36.4 & 2.0 & 18.8 & 62.7 & 120.4 & 0.2 \\
690904001 & 31.7 & 0.0 & 21.5 & 71.6 & 117.2 & 0.2 \\
690904002 & 40.9 & 0.0 & 22.9 & 76.3 & 139.4 & 0.2 \\
690904003 & 28.9 & 0.0 & 17.9 & 59.7 & 118.7 & 0.2 \\
690910001 & 29.9 & 0.0 & 17.9 & 59.7 & 110.1 & 0.2 \\
690925001 & 39.7 & 0.0 & 27.7 & 92.3 & 162.4 & 0.2 \\
690925003 & 41.9 & 0.0 & 23.1 & 77.0 & 153.2 & 0.2 \\
690925005 & 17.7 & 0.0 & 13.2 & 44.0 & 95.8 & 0.1 \\
690925007 & 47.2 & 0.0 & 25.7 & 85.7 & 181.2 & 0.1 \\
\hline Average & 32.4 & 0.3 & 20.8 & 69.3 & 125.9 & 0.2 \\
\hline \hline
\end{tabular}

*milliequivilent in grams

after Gross, 1970

Table 11. Total Carbon Composition of Suspended Solid Material in Sewage

\begin{tabular}{|l|c||l|c|}
\hline Carbon Form & Percent & Carbon Form & Percent \\
\hline \hline Unidentified & 63.0 & Fats - Ester & 1.0 \\
Protein & 20.0 & Fats - Acid & 1.0 \\
Carbohydrates & 10.0 & Muramic Acid & 0.4 \\
Amino Sugars & 3.0 & Anionic Detergents & 0.4 \\
Soluble Acids & 1.0 & Amide & 0.2 \\
\hline
\end{tabular}

after Walter, 1961 
averages 8 to 10 percent organics (Panuzio, 1965). Hudson River sediments have an average organic matter content of 5.5 percent (McCrone, 1967). Much of the organic matter in dredge spoils from harbor areas consists of petrochemicals. (Saila, 1968).

Distribution of waste deposits in New York Harbor and nearby waters was studied by the SUNY-SB. They measured the abundance of carbon-rich wastes on the Continental Shelf using loss-on-ignition (volatile matter) or total-carbon techniques. Loss on ignition (volatile matter), and total carbon concentrations of deposits from the New York Bight dumping grounds and adjacent areas are shown in Figures 33, 34.

Within the Harbor, the total carbon concentrations served as an index of organic matter abundance. About 160 square kilometers (62 square miles or 40 percent) of the total harbor area is covered by fine grained wastes containing more than 2 percent total carbon. Sewage solids are suspected of contributing most of the carbonaceous material. Distribution of carbon-rich surface deposits in the Harbor and adjacent waters is shown in Fig. 35. Outside the Harbor, the area on the Shelf covered by sediments with more than 2 percent total carbon, or 5 percent volatile matter, is about 50 square kilometers (20 square miles). Sediments with more than 1 percent total carbon were found to cover about 100 square kilometers (40 square miles). Oxidizable carbon and reducing capacity of the deposits were correlated with the abundance of total carbon in the deposits. The waste deposits in the dumping grounds, according to Gross (1970), had median total carbon concentrations that were 30 times greater than the median for Continental Shelf deposits.

f. Other Chemical Species. Acid wastes in the New York Bight acid dumping grounds consist of about 8.5 percent sulphuric acid and 10 percent ferrous sulphate in solution. The acid, according to Redfield and Walford, (1951), is rapidly neutralized; the ferrous sulphate is oxidized to the ferric state and precipitates as the hydroxide which is easily traced in the bottom sediments. This is the major source of iron in the area, other than occasional contributions from river water, northeast of the dumping grounds. The disposal of acid wastes has resulted in an easily identified, iron-rich, water mass, which sinks and is moved northeast along the bottom by currents. High iron concentrations for these waters have been reported in the past by Ketchum, Redfield and Ayers (1951) and by Ketchum et al, (1958). These investigators found a maximum of about 1 microgram-atom per liter $(\mu g-a t / 1)$ in 1950 and $4 \mu \mathrm{g}-a t / 1$ in $1958 \mathrm{com}-$ pared with the average of maximum values of $8.9 \mu \mathrm{g}$-at $/ 1$, found in 196970. This increase in concentration has been attributed to the increase in the discharge of iron in the area from 60 tons per day in 1948, to 80 tons per day in 1950, and 229 tons per day in 1969-70.

High iron concentrations in the waters were confirmed by the SHL study of the area. The total concentration of iron for surface, middepth and bottom water averaged from .46 to $3.42 \mu \mathrm{g}$-at $/ 1$, with higher values for bottom water. A single maximum measurement of $37.3 \mu \mathrm{g}-\mathrm{at} / 1$ was obtained by SHL near the acid dumping grounds. This measurement, 


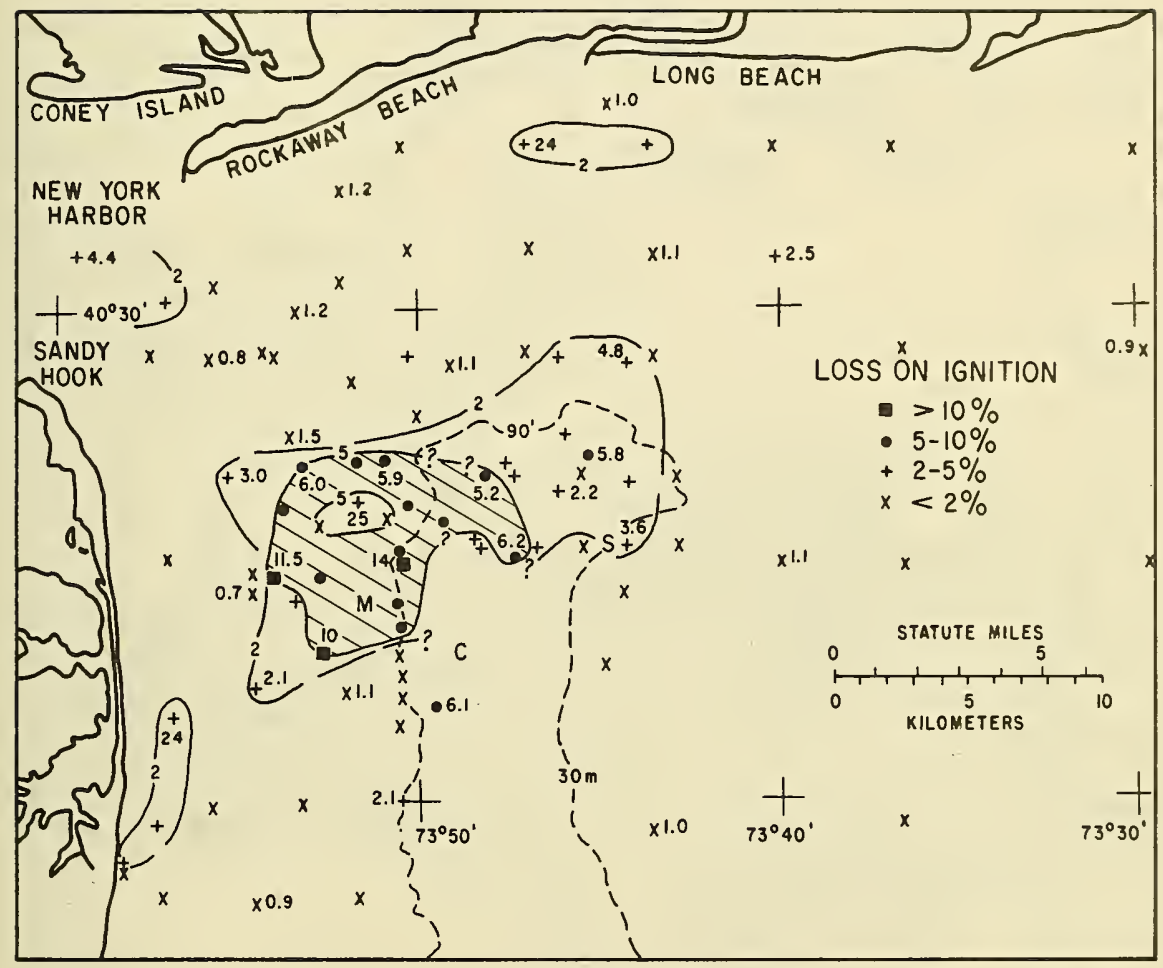

Figure 33. Loss-on-ignition (volatile matter) for Deposits from the New York Bight (After Gross, 1971) 


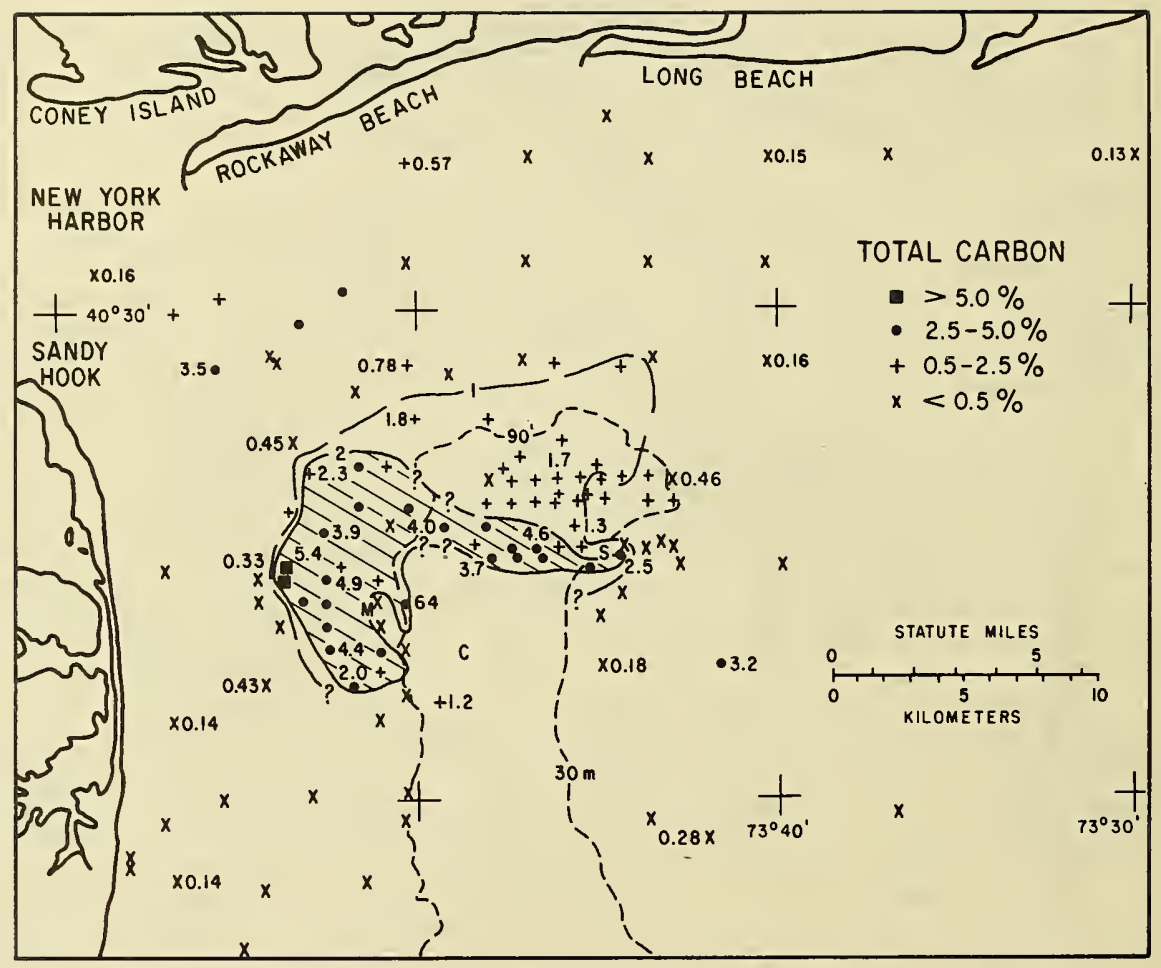

Figure 34. Total Carbon Concentrations in Deposits from the New York Bight (After Gross, 1971) 


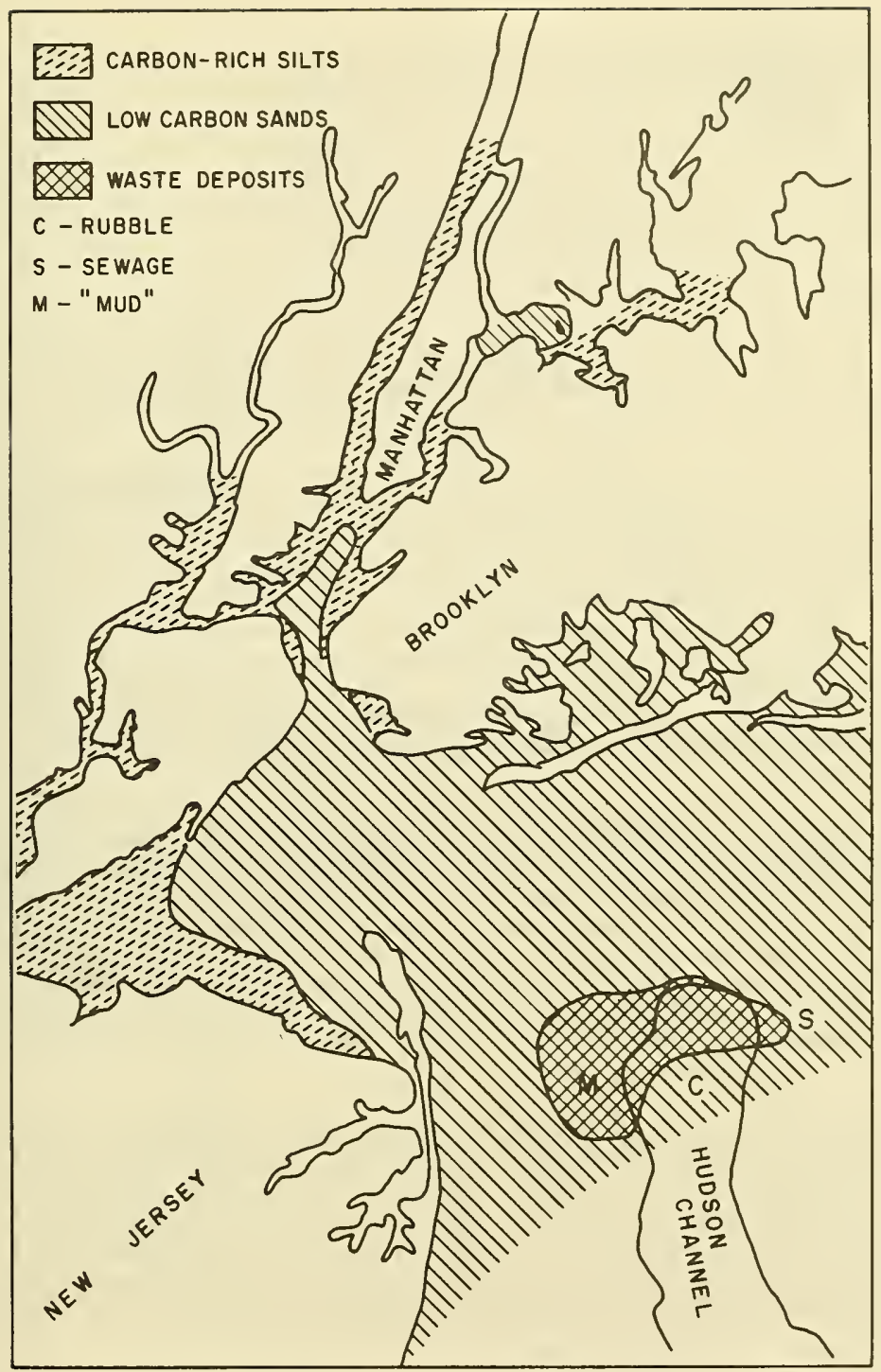

Figure 35. Distribution of Carbon-Rich Deposits in the Harbor and Carbon-Rich Waste Deposits on the nearby Shelf (After Gross, et al, 1971) 
however, may have been made shortly after a dump. The surface, mid-depth and bottom iron concentrations in the water for the area are shown in Figures 36, 37, and 38. These plots have sharp contours to the south and southwest of the area of interest. The patterns of iron distribution suggest spreading of iron-rich waste along the bottom by bottom currents. A correlation has been suggested by SHL between the iron-rich water in the disposal area and an increase in turbidity.

\section{Biological Characteristics}

A number of biological investigations of the Bight have been conducted (Buelow, et al, 1968; Jeffries, 1959; Redfield and Walford, 1951; Herman, 1963; Segal, 1970; Barber and Krieger, 1970).

Biological studies were also undertaken by the Sandy Hook Laboratory which included investigations of benthic life, zooplankton, and finfish. Since August 1968, SHL began sampling (Figure 39) in the Bight with the intent to pay particular attention to certain commercially valuable forms, such as the surf clam, the American lobster, and the common cancroid, or rock crab. These benthic species, however, were not studied adequately. Additional studies of coliform and pathogenic microorganisms have been carried out by numerous investigations. (At1as, 1972; Mahoney, 1972; Buelow, et al, 1968). The biological characteristics of an area of the Bight, within and outside the dumping grounds, are discussed in the following sections:

a. Benthos. The study of benthic communities is considered the most direct approach in assessing the effect of ocean waste disposal, as most benthic organisms are immobile and their presence or absence reflects longterm change in the marine environment. The distribution of benthic species is related to many factors such as the sediment type, the presence of toxic materials, water quality, nutrients, and pathogenic organisms. Studies of benthic communities in the Bight and within the Harbor have been undertaken by the SUNY-SB and the SHL. The results of these studies are not in full agreement.

A preliminary biological reconnaissance by SUNY found only a few groups of pollution-tolerant organisms, such as nematodes and capitellid worms, in abundance in the sediments of the inner Harbor. Numbers of benthic animals in most of the Inner Harbor, were either drastically diminished, or totally lacking. In the Lower Bay, benthic communities were apparently less severely affected. Near the harbor entrance, the Continental Shelf appeared to support near-normal communities of benthic organisms.

The SHL study found populations of benthic animals in the vicinity of the dumping grounds severely impoverished. Nematodes, which are regarded as a pollution-resistant group, were found in reduced numbers within the dumping grounds. Areas peripheral to the sewage sludge dumping grounds were dominated by Cerianthus, a burrowing type of sea anemone. Species diversity of benthic organisms, which is often used as an index of 


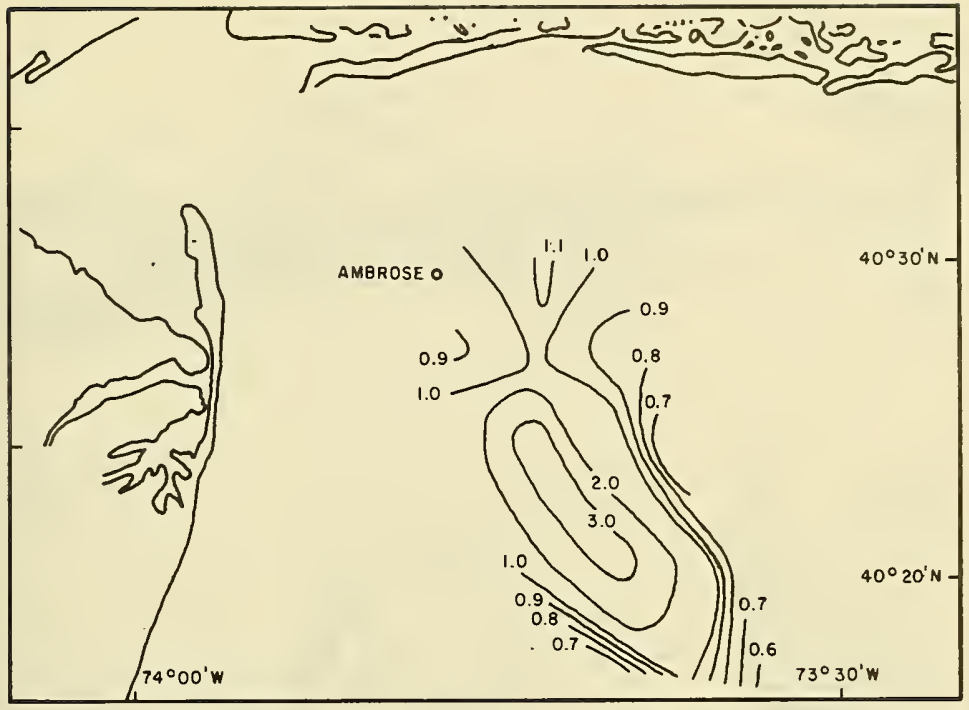

Figure 36. Total Iron ( $\mu g-a t / 1)$ Water Surface Average by Station

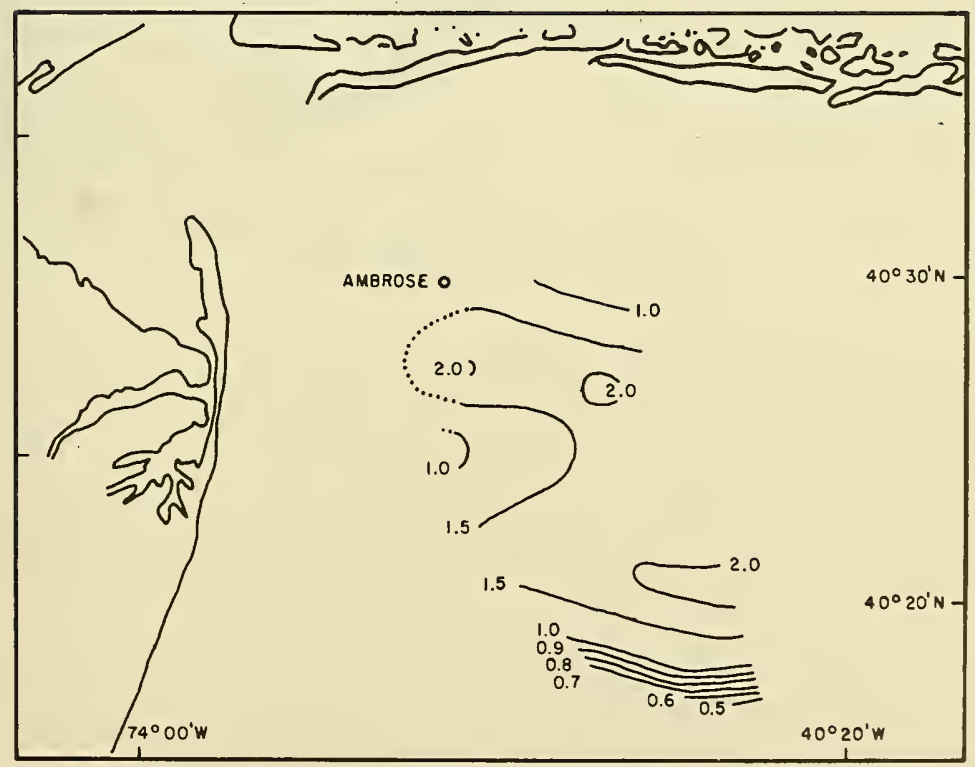

Figure 37. Total Iron ( $\mu g-a t / 1)$ in Water Bottom Average by Station (After SHL, 1972 


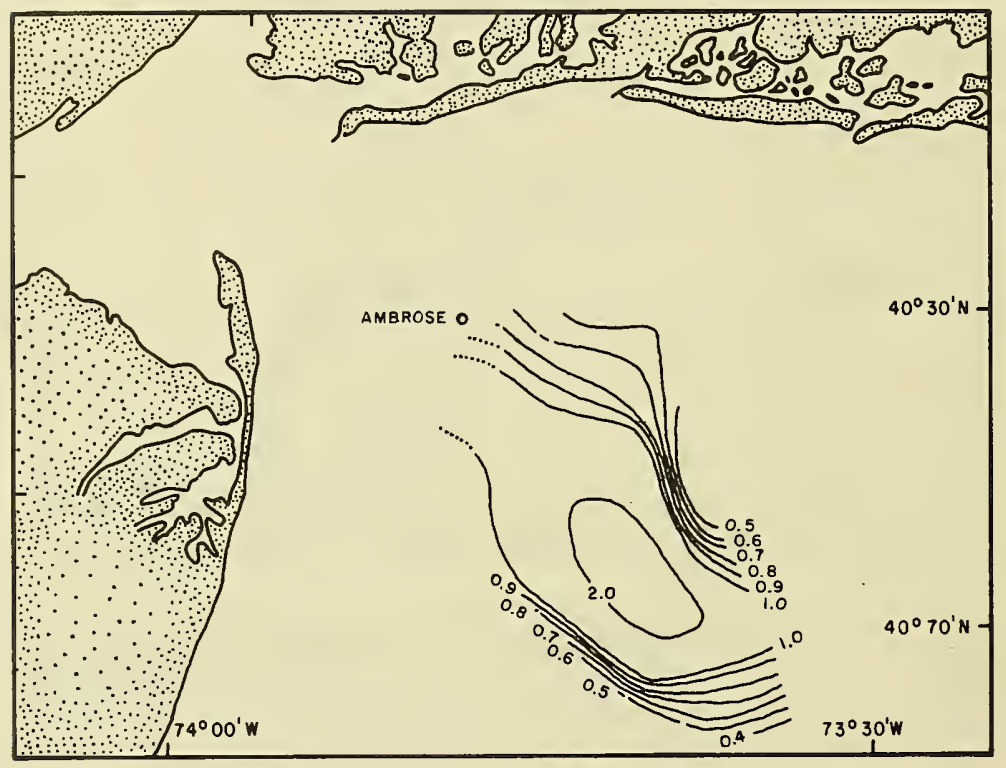

Figure 38. Total Iron ( $\mu$ g-at/1) Mid Water depth Average by Station (After SHL, 1972) 


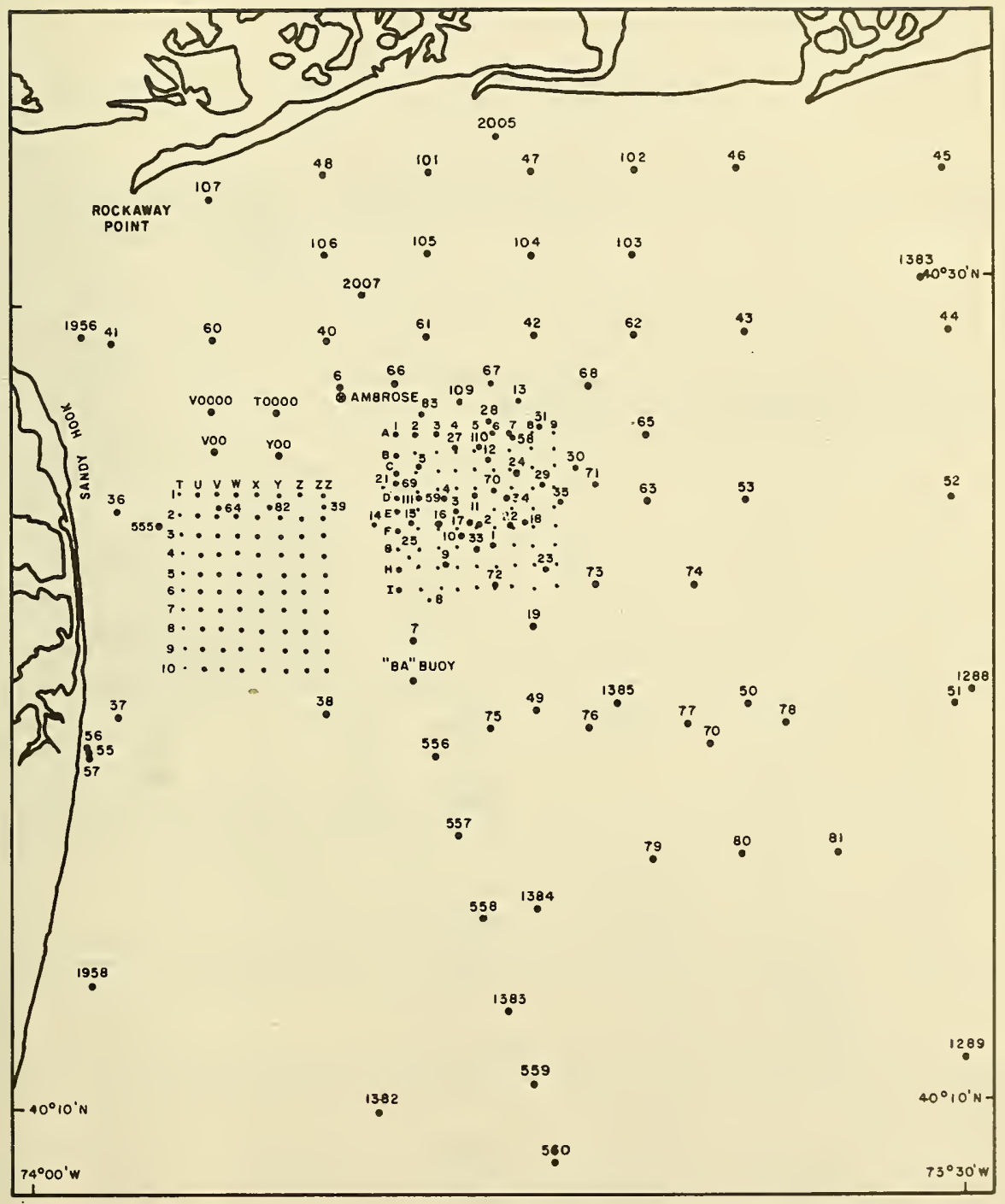

Figure 39. Stations Occupied by SHL for Biological Sampling 
Table 12. "Species Diversity" at Sampling Stations Within and Outside the Disposal Grounds. According to SHL (1972)

In I (the bottom line of boxes), the fourth entry from the bottom should read Capitellidae instead of Cirratulidae.

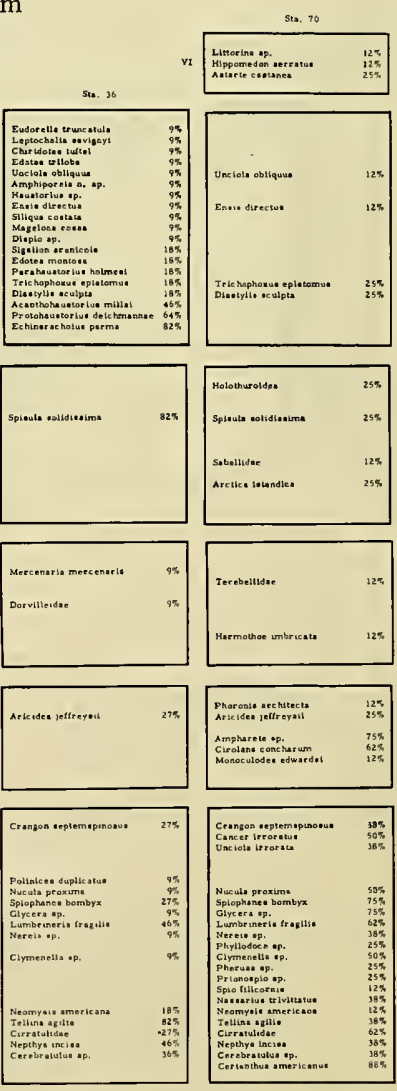


Table 12. "Species Diversity"-Continued

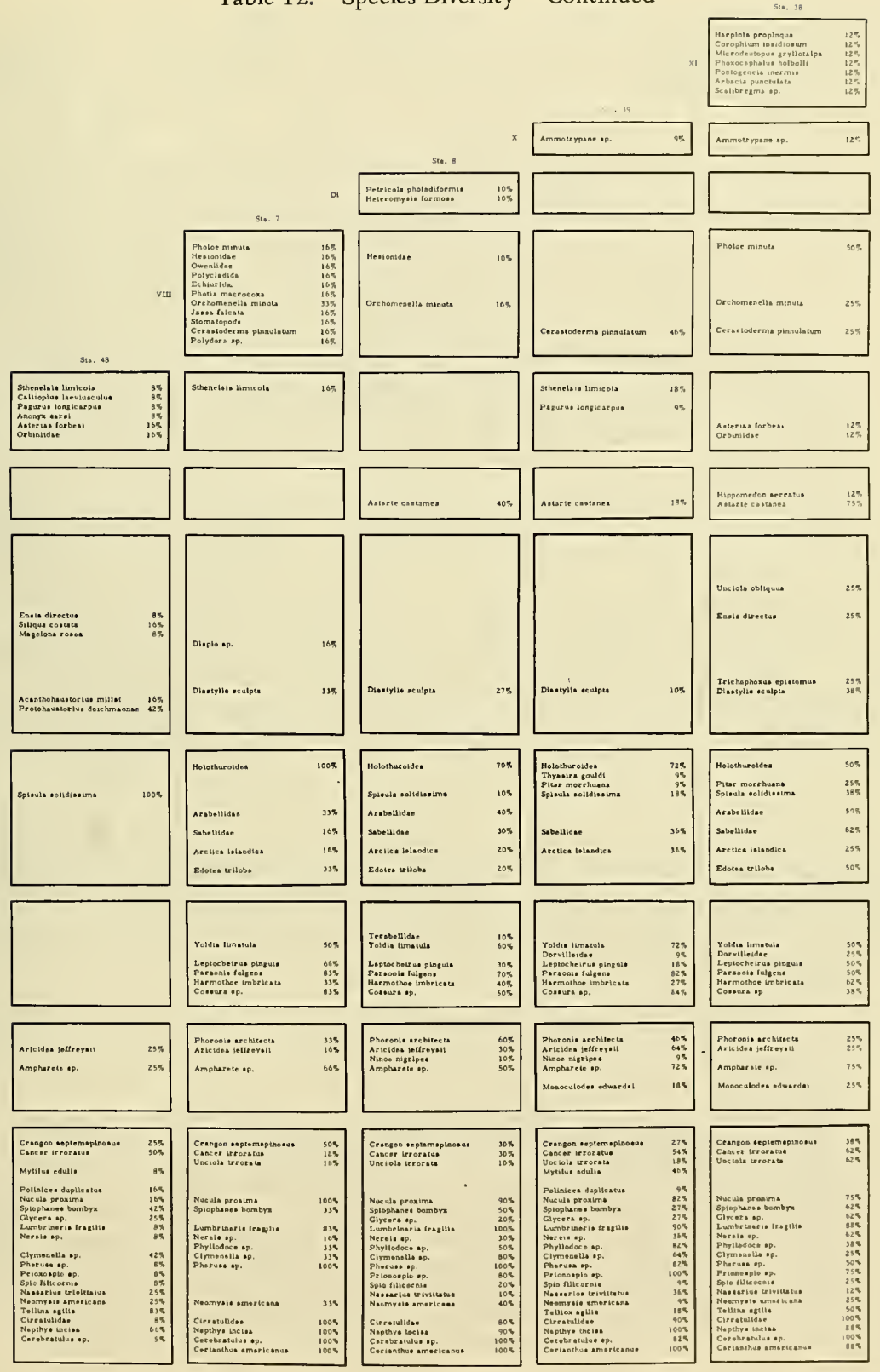


environmental stress, was found to be generally lower within the designated dumping grounds. Table 12, taken from the SHL report, reportedly compares the "species diversity" of benthic communities for selected stations within and outside the dumping grounds. In this table, species which were found at the least "diversified" station (\#82, dredge spoil disposal site) are listed at the extreme left of the table. Species common to the next least "diversified" station (\#42, northeast of the dumping grounds) were listed to the right of the first column of species. Species common to the first and the second stations were listed in the second column (\#42) and in addition, species which were found at station \#42 but not at station \#82, were placed in a new listing (Row II) above the previous stations. A matrix therefore was developed by SHL of vertical columns designated by station numbers, and horizontal rows indicated by Roman numerals, giving the "species diversities" at different stations. The percentage of the samples in which each species occurred at each sampling station is given after the species name. These numbers give an indication of species abundance, but may not be statistically valid since no information is given on frequency of sampling and sampling methodology. Some other discrepancies in interpreting the data of table 12 should be pointed out. According to this table, station \#82 (dredge spoil disposal site) had a lower "species diversity" than any other station. Station \#42, however, northeast of the dumping grounds, had the same "species diversity" as station \#82 (23 species) while station \#59 (the sewage sludge dump site) had greater "species diversity" than both \#82 and \#42, but considerably less than station \#38, which is located south of the dumping grounds. The data in table 12 therefore, represents only data at random, and a speculative use of species diversity. A concurrent sweep of environmental parameters together with biological sampling along a transect, would have been a better method of illustrating differences in environmental gradient.

Some of the results on benthic communities of the SHL are not in full agreement with those of the SUNY-SB study. An assessment of the findings of both investigations is given in the discussion section of this report dealing with the effects of ocean dumping on the regional ecology. Similarly, in the same section, the use of species diversity as an index of environmental stress is discussed.

In the following sections, a summary is given on some of the biological characteristics of benthic populations, as established by these preliminary investigations.

(1) Meiofauna. Meiofauna is defined operationally as those animals that can pass through a $1.00 \mathrm{~mm}$ standard geological screen but are retained on a 63 micron screen. These organisms, especially foraminifera, are near the base of the benthic food chain, and are the most common ecologically significant group of animals in the marine sediments of the New York Bight. Because of their abundance, intimate association with the sedimentary environment, and limited mobility, these animals should be the most sensitive to any degradation of the sediments and of the interstitial water. Therefore, studies of meiofauna, especially the 
foraminifera, could be important in assessing the effects of ocean dumping. Such studies should be designed so that the obtainable data can be treated statistically to determine whether or not significant differences exist between stations, in space and time (SAC, 1972).

The SHL studied infaunal meiofauna and identified 36 common meiofaunal taxa from the sediments of the Bight; 23 were living foraminiferans. Rare forms, such as cumaceans and phoronids, were not included. Foraminifera were identified by species; the remaining groups were identified to higher taxonomic groups such as nematodes, bivalves, etc. The composition of meiofaunal communities, at selected stations in and surrounding the sewage sludge and dredging spoils disposal areas, is given in Table 13. Stations $\mathrm{F}-3$ and $\mathrm{F}-4$ are within the sewage dumping grounds, station F-5 is at the outside perimeter, and station 11 is outside to the east of the sewage dumping grounds. Stations 59 and 82 mark the centers of the sewage sludge and dredge spoil disposal grounds, respectively. Station 39 is between the two disposal areas.

Within the disposal areas, SHL found reduced species diversity of meiofaunal organisms, and concluded that meiofaunal communities are affected by the disposal of wastes. According to SHL, relative numbers of individuals representative of specific taxa were also reduced. Amphipods were generally absent from the dumping ground. Nematodes, which are reportedly a pollution-resistant group, were found in reduced numbers. Table 14 gives a comparison of the abundance of gammarid amphipod populations in the sewage sludge and dredging spoils disposal areas and at stations outside these areas. Table 12 compares the species diversity at sampling stations within and outside the disposal grounds.

A reconnaissance study of the meiofauna in New York Harbor and adjacent waters by Smith (Gross, et al, 1971) is in disagreement with the results of the SHL. This investigation found foraminifera greatly depleted in the sediments in the Harbor area, but in typical abundance and diversity in the sediments of the Bight. Both studies, however, did not adequately sample meiofauna in time and space, and the results cannot be treated with statistical methods to assess and quantify the effect of waste disposal, if any. An assessment of the reliability of meiofauna investigations is given in the discussion section of this report.

(2) Macrofauna. Benthic macrofauna are considered animals larger than $1 \mathrm{~mm}$. The SHL investigation found at least 81 macrofaunal species which occurred with sufficient frequency in the Bight to plot their distribution in relation to type of sediments and the waste disposal sites. The geographical distribution of such benthic macrofaunal species is presented in Figures 2-34 through 2-117 of the original SHL report to which the interested reader is referred. Because of its volume, this data is not reproduced in this report. Table 15, is a listing of these benthic macrofaunal species arranged in a standard phylogenetic order. The species marked with an asterisk were sampled in the immediate area of the dumping grounds. 
Table 13. Composition of Meiofaunal Communities at Selected Stations in and Around the Sewage Sludge and Dredge Spoil Disposal Grounds.

\begin{tabular}{|c|c|c|c|c|c|c|c|c|c|c|c|c|}
\hline & $\begin{array}{c}25 \\
\text { July } \\
69\end{array}$ & $\begin{array}{c}25 \\
\text { July } \\
69\end{array}$ & $\begin{array}{c}25 \\
\text { July } \\
69\end{array}$ & $\begin{array}{c}3 \\
\text { June } \\
69\end{array}$ & $\begin{array}{c}28 \\
\text { July } \\
69\end{array}$ & $\begin{array}{c}27 \\
\text { Aug. } \\
69\end{array}$ & $\begin{array}{c}20 \\
\text { Aug. } \\
70\end{array}$ & $\begin{array}{c}20 \\
\text { Aug. } \\
69\end{array}$ & $\begin{array}{c}27 \\
\text { Aug. } \\
69\end{array}$ & $\begin{array}{c}3 \\
\text { Mar. } \\
70\end{array}$ & $\begin{array}{c}20 \\
\text { Aug. } \\
69\end{array}$ & $\begin{array}{c}12 \\
\text { Mar. } \\
71\end{array}$ \\
\hline Species & F-3 & $\mathrm{F}-4$ & F-5 & 11 & 11 & 39 & 39 & 59 & 59 & 59 & 82 & 82 \\
\hline Elphidium incertum & & & $\mathrm{x}$ & & 124 & $\mathrm{x}$ & 46 & & & & 19 & \\
\hline E. clavatum & & & $\mathrm{X}$ & & 24 & $\mathrm{x}$ & 328 & 32 & 14 & 5 & 23 & 0 \\
\hline E. subarcticum & & & & & 16 & $\mathrm{X}$ & 20 & & & & 4 & \\
\hline Elphidium sp. misc. & 162 & 44 & & & 58 & $\mathrm{x}$ & 52 & 109 & & 15 & 23 & \\
\hline Reophax scottii. & 83 & 24 & & & & 5 & 877 & 74 & 12 & 9 & 24 & 0 \\
\hline Ammodiscus sp. & & 18 & & & 4 & & 4 & & 12 & & & \\
\hline Eggerella advena & 31 & 22 & $\mathrm{X}$ & & 44 & $\mathrm{X}$ & 49 & 290 & 6 & 4 & & \\
\hline Trochammina lobata & & & & & 6 & & 0 & & 6 & & & \\
\hline T. squamata & & & & & 4 & & 0 & & & & & \\
\hline T. advena & & & & & & & & & & & 4 & \\
\hline Quinqueloculina seminula & 0 & & & & & & 12 & & & & & \\
\hline Pseudopolymorphina norvangliae & & & $\mathrm{X}$ & & & 5 & & & & & & \\
\hline Ammonia beccarii & & & & & & $\mathrm{X}$ & & & & & & 0 \\
\hline Buccella frigida & & & & & 22 & & & & & & & \\
\hline Bolivina pseudoplicata & & & & & 2 & & & & & 4 & & \\
\hline Buliminella elegantissima & & & & & 6 & & & & & & & \\
\hline Textularia sp. & & & & & & 1 & 4 & 3 & & & & \\
\hline Alveolophragmium jeffreysii & & & & & & & & 1 & & & & \\
\hline Cibicides lobatulus & & & $\mathrm{X}$ & & & & & & & & & \\
\hline Proteonina sp. & & & 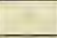 & & & & 16 & & & & & \\
\hline Nematoda & 302 & 1298 & 80 & 324 & 100 & 1735 & 381 & 266 & 254 & 79 & 91 & 46 \\
\hline Polychaeta & 11 & 4 & & 1 & & 26 & 80 & & 6 & & & \\
\hline Tintinnia & 6 & 2 & 8 & 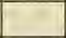 & & 2 & 16 & & 0 & 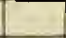 & & \\
\hline Harpacticoidea & 55 & 52 & & 5 & & 7 & 249 & 25 & 2 & 8 & 4 & 9 \\
\hline Podocopa & & & & & & & 0 & & & & & \\
\hline Halacaridae & 2 & 6 & 2 & & & 2 & & 1 & & 1 & 0 & \\
\hline Bivalvia & & 2 & 17 & & & 22 & 16 & & 18 & 4 & 4 & \\
\hline Rhabdocoela & & & & & & 5 & 4 & & & & & \\
\hline Desmoscolex sp. & & 4 & & & & & 1 & & & & & \\
\hline Kinorhyncha & 1 & 2 & & & & & 8 & & & 1 & & \\
\hline Amphipoda & & & 2 & & & & & & & & & \\
\hline Heterotardiggrada & & & & & & & & & 0 & & & \\
\hline
\end{tabular}

$\mathrm{X}$ Indicates the presence of a species

from SHL, 1972 
Table 14. Comparison of the Abundance of Gammarid Amphipod Populations in the Sewage Sludge and Dredge Spoils Disposal Areas and at Stations Outside these Areas.

\begin{tabular}{|l||r|r|r|r|}
\hline \multicolumn{1}{|c||}{ Present Survey } & $\begin{array}{c}\text { Number of } \\
\text { Stations } \\
\text { Sampled }\end{array}$ & $\begin{array}{c}\text { Number of } \\
\text { Times } \\
\text { Sampled }\end{array}$ & $\begin{array}{c}\text { Number of } \\
\text { Amphipods }\end{array}$ & $\begin{array}{c}\text { Avg. No. of } \\
\text { Amphipods } \\
\text { per Sample } \\
\left(0.1 \mathrm{~m}^{2}\right)\end{array}$ \\
\hline \hline Dredge Spoil Area & 11 & 18 & 1 & 0.055 \\
Dredge Spoil Margin & 3 & 3 & 11 & 3.66 \\
Sewage Disposal Area & 27 & 70 & 48 & 0.69 \\
Sewage Margin & 18 & 36 & 82 & 2.27 \\
Remainder N.Y. Bight & 170 & 275 & 3,104 & 11.28 \\
\hline \multicolumn{1}{|c||}{ Total } & 229 & 402 & 3,246 & 8.07 \\
\hline \hline \multicolumn{1}{|c|}{ Nassau } & 18 & 198 & 828 & 4.18 \\
\hline \hline A, B, and C Transects & 22 & 242 & 6,185 & 25.57 \\
D, E, F, and G Transects & 40 & 440 & 7,013 & 15.94 \\
\hline \multicolumn{1}{|c|}{ Total } & \multicolumn{2}{|c}{} \\
\hline
\end{tabular}


Table 15. Benthic Macrofaunal Species Sampled at Dumping Grounds and Adjacent Areas. (*Species sampled within 2 nautical miles of the center of each particular disposal site.

\begin{tabular}{|c|c|c|c|}
\hline $\begin{array}{l}\text { Arranged in a Standard } \\
\text { Phylogenetic Order }\end{array}$ & $\begin{array}{l}\text { Dredge } \\
\text { Spoils } \\
\text { Site }\end{array}$ & $\begin{array}{c}\text { Sewage } \\
\text { Sludge } \\
\text { Site }\end{array}$ & $\begin{array}{c}\text { Acid } \\
\text { Wastes } \\
\text { Site }\end{array}$ \\
\hline Cerianhus americanus & * & * & * \\
\hline Cerebratulus lacteus & * & * & * \\
\hline Ampharete sp. & * & * & * \\
\hline \multicolumn{4}{|l|}{ Arabellidae } \\
\hline Cirratulidae & * & * & * \\
\hline Cossura sp. & * & * & \\
\hline Dorvilleidae & * & * & \\
\hline Pherusa affinis & * & * & \\
\hline Glycera sp. & * & * & * \\
\hline Lumbrineris fragilis & * & * & * \\
\hline Clymenella sp. & * & * & \\
\hline Nephtys incisa & * & * & * \\
\hline Nereis sp. & * & * & \\
\hline Orbiniidae & & * & * \\
\hline Aricidea jeffreysii & * & * & * \\
\hline Paraonis fulgens & * & * & * \\
\hline Phyllodoce sp. & * & * & * \\
\hline Harmothoe imbricata & * & * & \\
\hline Sabellidae & * & * & * \\
\hline Pholoe minuta & * & * & * \\
\hline Dispio uncinata & * & * & \\
\hline Prionospio malmgreni & * & * & * \\
\hline Spio filicornis & * & * & \\
\hline Spiophanes bombyx & * & * & * \\
\hline Streblospio benedicti & & * & \\
\hline Copepoda & * & * & * \\
\hline Diastylis sculpta & & * & * \\
\hline Edotea triloba & * & * & * \\
\hline \multicolumn{4}{|l|}{ Caprellidae } \\
\hline Ampelisca macrocephala & & * & * \\
\hline Ampelisca valdorum & * & & \\
\hline \multirow{2}{*}{\multicolumn{4}{|c|}{$\begin{array}{l}\text { Microdeutopus gryllotalpa } \\
\text { Mictoris pinguis }\end{array}$}} \\
\hline & & & \\
\hline Argissa hamatipes & * & * & \\
\hline \multicolumn{4}{|l|}{ Calliopius laeviusculus } \\
\hline Corophium insidiosum & & * & \\
\hline Unciola irrorata & * & * & * \\
\hline Unciola obliquua & & * & * \\
\hline \multicolumn{4}{|l|}{ Pontogeneia inermis } \\
\hline \multicolumn{4}{|l|}{ Elasmopus laevis } \\
\hline \multicolumn{4}{|l|}{ Gammarus annulatus } \\
\hline Melita nitida & & & \\
\hline
\end{tabular}


Table 15. Benthic Macrofaunal Species Sampled at Dumping Grounds and Adjacent Areas--Continued

\begin{tabular}{cccc}
\hline $\begin{array}{c}\text { Arranged in a Standard } \\
\text { Phylogenetic Order }\end{array}$ & $\begin{array}{c}\text { Dredge } \\
\text { Spoils } \\
\text { Site }\end{array}$ & $\begin{array}{c}\text { Sewage } \\
\text { Sludge } \\
\text { Site }\end{array}$ & $\begin{array}{c}\text { Acid } \\
\text { Wastes } \\
\text { Site }\end{array}$ \\
\hline
\end{tabular}

Acanthohaustorius millsi

Amphiporeia n. sp.

Haustorius sp.

Parahaustorius holmesi

Protohaustorius deichmannae

Protohaustorius wigleyi

Pseudohaustorius n. sp.

Ischyrocerus anguipes

Jassa falcata

Photis sp.

Photis macrocoxa

Anonyx sarsi

Hippomed on serratus

Orchomene1la minuta

Monoculodes edwardsi

Harpinia sp.

Harpinia propinqua

Phoxocephalus holbolli

Trichophoxus epistomus

Dulichia monocantha

Metopa alderi

Syrrhoe sp.

Neomysis americana

Crangon septemspinosus

Pagurus longicarpus

Cancer irroratus

Nassarius trivittatus

Nucula proxima

Yoldia limatula

Mytilus edulis

Astarte castanea

Cerastoderma pinnulatum

Cyprina islandica

Ensis directus

Mercenaria mercenaria

Siliqua costata

Spisula solidissima

Tellina agilis

Chaetognatha

Phoronis architecta

Echinarachnius parma

Holothuroidea 
Only the distribution and abundance of two economically significant species, surf clams (Spisula solidissima) and rock crabs (Cancer irrogatus) are presented schematically in Figures 40 and 41 , respectively. Table 16 gives the distribution and abundance of three dominant organisms (Cerianthus, Cerebratulus and Nephtys) in the waste disposal areas. Of interest in this table is the reduced average numbers of organisms at stations 59 and 82 , the centers of the sewage sludge and dredging spoils disposal areas, respectively. The SHL macrofauna survey is not complete in that it does not include the distribution and abundance of the commercially valuable rock clam, and ocean quahog, and there are no data concerning the lobster.

SHL investigation found a small number of juvenile rock crabs within the disposal areas relative to the noncontaminated regions, suggesting that larvae of crabs do not readily settle in the area of the dumping grounds. On the basis of its investigations, SHL concluded that an area of about 2 miles in diameter as at each of the dumping sites, was devoid of what was considered normal or was characterized by greatly reduced macrofaunal populations. The reported decrease in species diversity was similarly attributed to environmental stress caused by the waste dumping activities. It should be emphasized, however, that SHL did not analyze its data statistically, and this conclusion is not obvious in the tables and figures summarizing the SHL results. An assessment of these results is given in the discussion section of this report dealing with the effects of ocean dumping on the regional ecology.

(3) Coastal and Bottom-Dwelling Finfishes. In an effort to determine the effect of ocean dumping of sewage sludge on demersal or bottom-dwelling finfishes, SHL trawled in and outside the sewage sludge beds. No attempt was made by SHL to sample the area of the dredge spoil grounds, west of the sewage dump, because this area has a rugged bottom and a large section is closed to trawling because old mines are known to exist.

Trawl samples and fish stomach analyses by SHL indicate that the local groundfishes frequent the area of the sewage dumping grounds. In fact their numbers were found to be greater in the center of the sewage dumping grounds than those found on a clear sand bottom, east of the dump site. From a total of 31 species of fish that were taken in and around the sewage sludge dumping area, 22 species were collected from the designated center of the dump. Of the species that were taken, whiting Merluccius bilinearis), ling (Urophysis chuss), winter flounder (Pseudopleuronectes americanus), yellowtail flounder (Limanda ferruginea), windowpane (Scophthalmus aquosus), and longhorn sculpin (Muoxocephalus octodecem spinosus), occurred most frequently. Other species of fishes were taken, but usually in lower numbers. Occasionally large numbers of fish such as Atlantic mackerel (Scomber scombrus), porgy (Stenotomus chrysops) and various herring were collected.

A special series of collections of demersal fishes was made by SHL across the Hudson Canyon, immediately south of the dumping area. Two of 


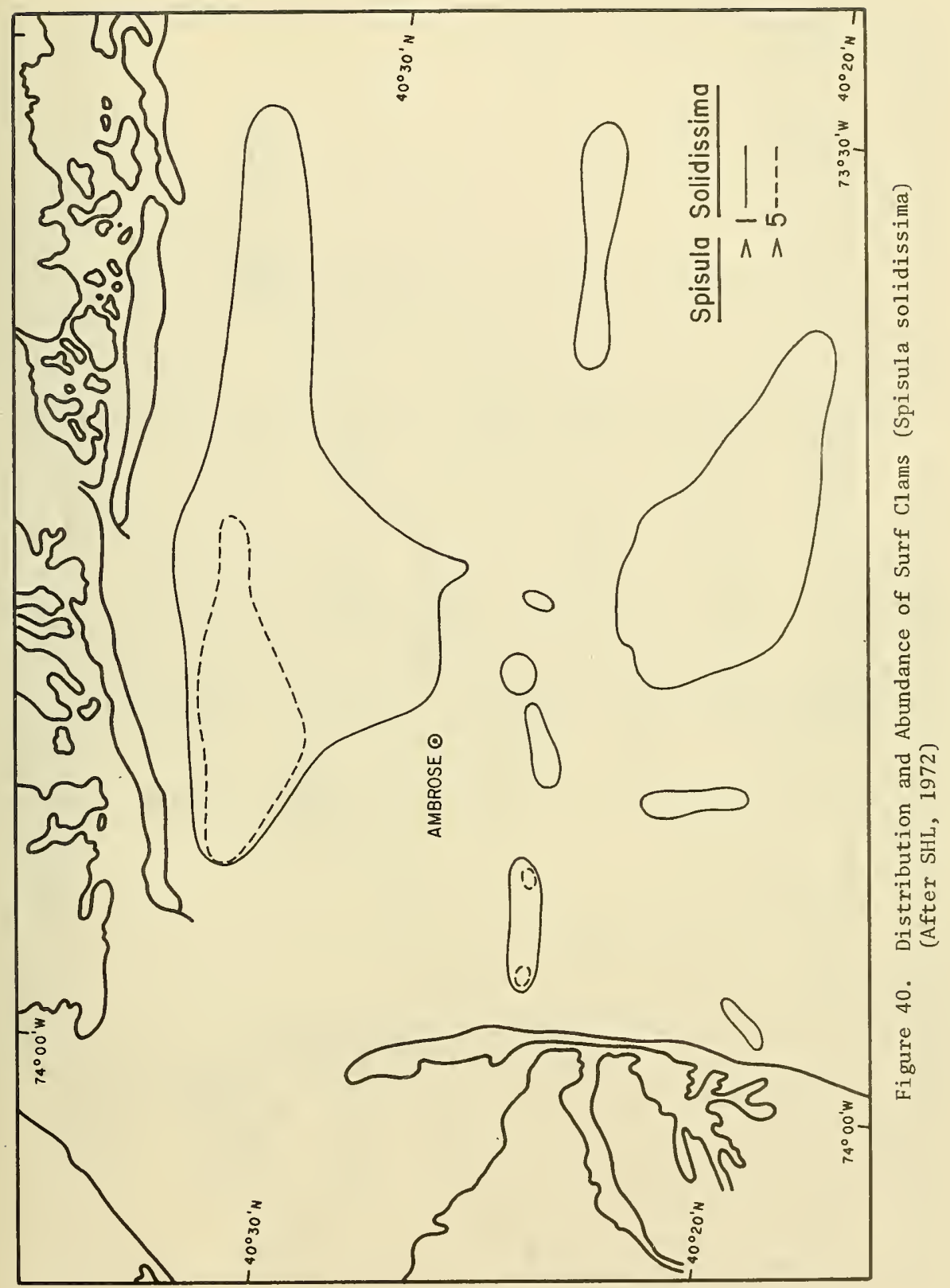




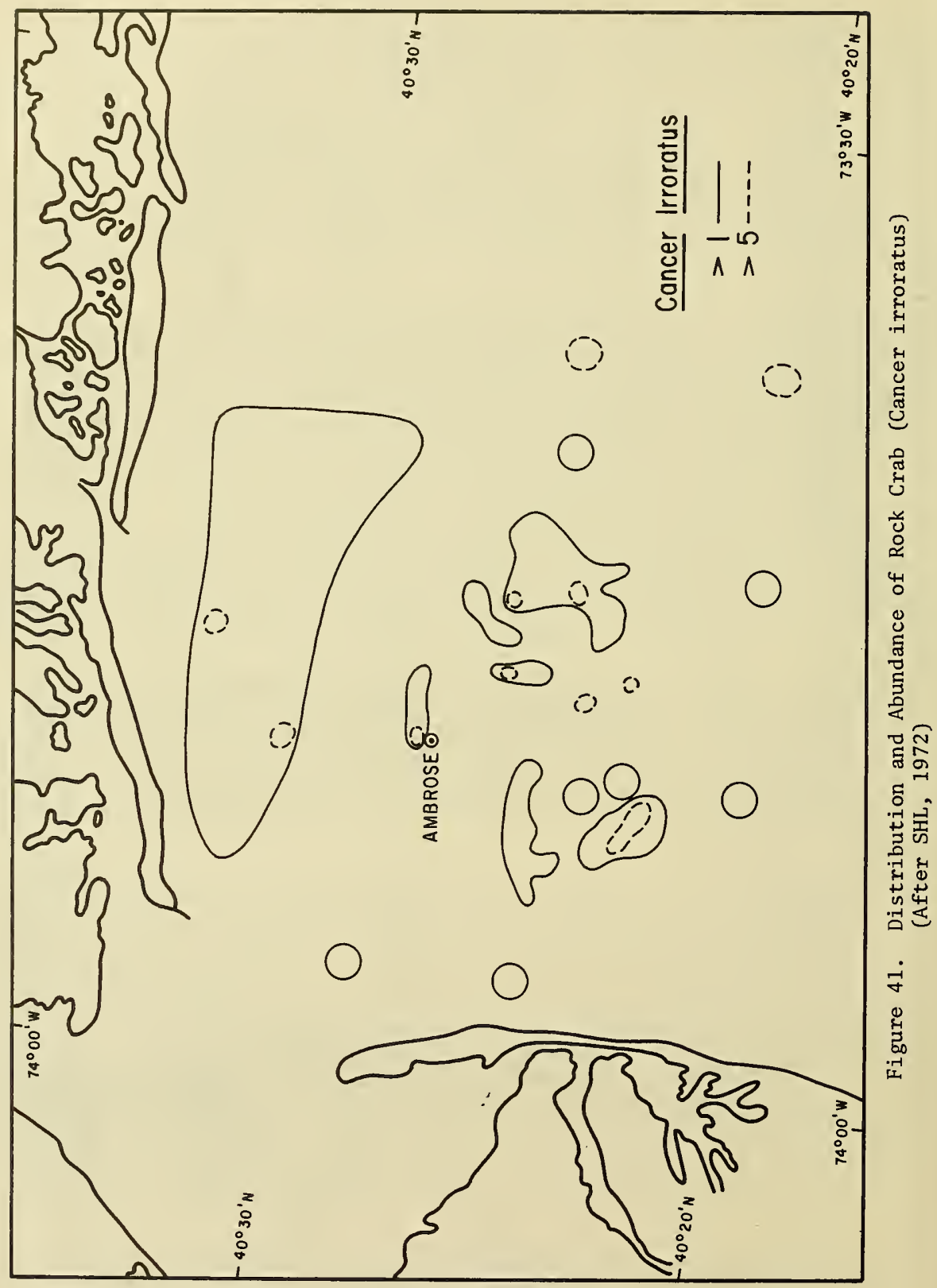


Table 16. Distribution and Abundance of Three Dominant Organisms in the Waste Disposal Areas.

\begin{tabular}{|c|c|c|c|c|c|c|}
\hline \multicolumn{7}{|c|}{ Species } \\
\hline \multirow{2}{*}{$\begin{array}{l}\text { Station } \\
\text { Number }\end{array}$} & \multicolumn{2}{|c|}{ Cerianthus } & \multicolumn{2}{|c|}{ Cerebratulus } & \multicolumn{2}{|c|}{ Nepthys } \\
\hline & Range & Average & Range & Average & Range & Average \\
\hline 7 & $10-58$ & 28.0 & $2-234$ & 56.0 & $1-16$ & 8.0 \\
\hline 8 & $1-92$ & 38.0 & $2-184$ & 45.0 & $0-22$ & 8.0 \\
\hline 38 & $0-30$ & 11.0 & $1-10$ & 52.0 & $0-38$ & 17.0 \\
\hline 39 & $1-51$ & 16.0 & $0-23$ & 10.0 & $0-19$ & 10.0 \\
\hline 59 & $0-44$ & 5.0 & $0-28$ & 5.0 & $0-28$ & 3.0 \\
\hline 82 & $0-2$ & 0.8 & $0-9$ & 2.0 & $0-3$ & 1.2 \\
\hline
\end{tabular}


the sampling stations were located on either side of the canyon, while the third station was in the center of it. Twelve of the 13 species collected occurred at all three stations. A total of 1,416 fish were taken from the station in the center of the canyon; only 207 were taken from the station closest to the New Jersey coast; 484 were taken from the station furthest away from it. The significantly higher number of fish taken at the canyon by SHL suggested that this is an area important to local fish populations. It is not known, however, whether greater numbers of fish frequent this area throughout the year or whether it is a seasonal occurrence. The role of Hudson Canyon as an important habitat for finfishes or as a spawning area should, therefore, be determined.

b. Zooplankton. Zooplankton serve as link between phytoplankton (primary producers) and the larger organisms of the sea. They are, therefore, important in marine food chains. Extensive studies of zooplankton populations within and outside the ocean dumping grounds of the Bight were made by the Sandy Hook Laboratory.

The samples of zooplankton were taken by SHL at different water depths (surface, middepth and bottom) using 1/2-meter-diameter nets with \# 8 mesh (.203 $\mathrm{mm}$ aperture) at different stations within and outside the waste dumping grounds, as shown in Figure 42. It is not known, however, whether the middepth samples were above, below or within the thermocline or pycnocline (the vertical gradient of density) which are known to vary in depth, seasonal1y. Flow meters were mounted in the mouths of the nets to allow calculation of the volume filtering through. The plankton nets were towed by SHL simultaneously at the three depths for 5-10 minutes, at intervals of 2 weeks, at six stations for which the data are recorded. A station in the sewage sludge disposal area and one in the acid-iron waste disposal area were included. Some of the sampling procedures and analytical methods used by SHL for this investigation have been questioned in the SAC review report. One criticism by SAC was that the counting technique used by the SHL, measured only a fraction of each of the total samples, and therefore is not considered adequate. According to the SHL method, a 1-milliliter subsample was counted and repeated until 300 copepods were included. One has no idea of the fraction of the actual sample counted. Many zooplankton specialists insist on counting the entire sample because, only then, can diversity indices be calculated, something which was not done by SHL. Another criticism by SAC pertaining to the SHL zooplankton study is that no analysis of variability of counts was provided. Replicate sampling would have been important, because in coastal waters zooplankton distributions are very patchy. The SHL counting method therefore introduced additional variation, and one has no way to judge the reliability of the data, nor the statistical significance.

The zooplankton data were often reported in settled volumes. These according to the SAC review are unreliable. The reason is that several hours or days are required for adequate settling of zooplankton, and not 5 minutes as in the SHL study. Furthermore, although the SHL method for determination of displacement volumes was found acceptable by the SAC, it is not the best method for biomass evaluation. Settled volumes are 


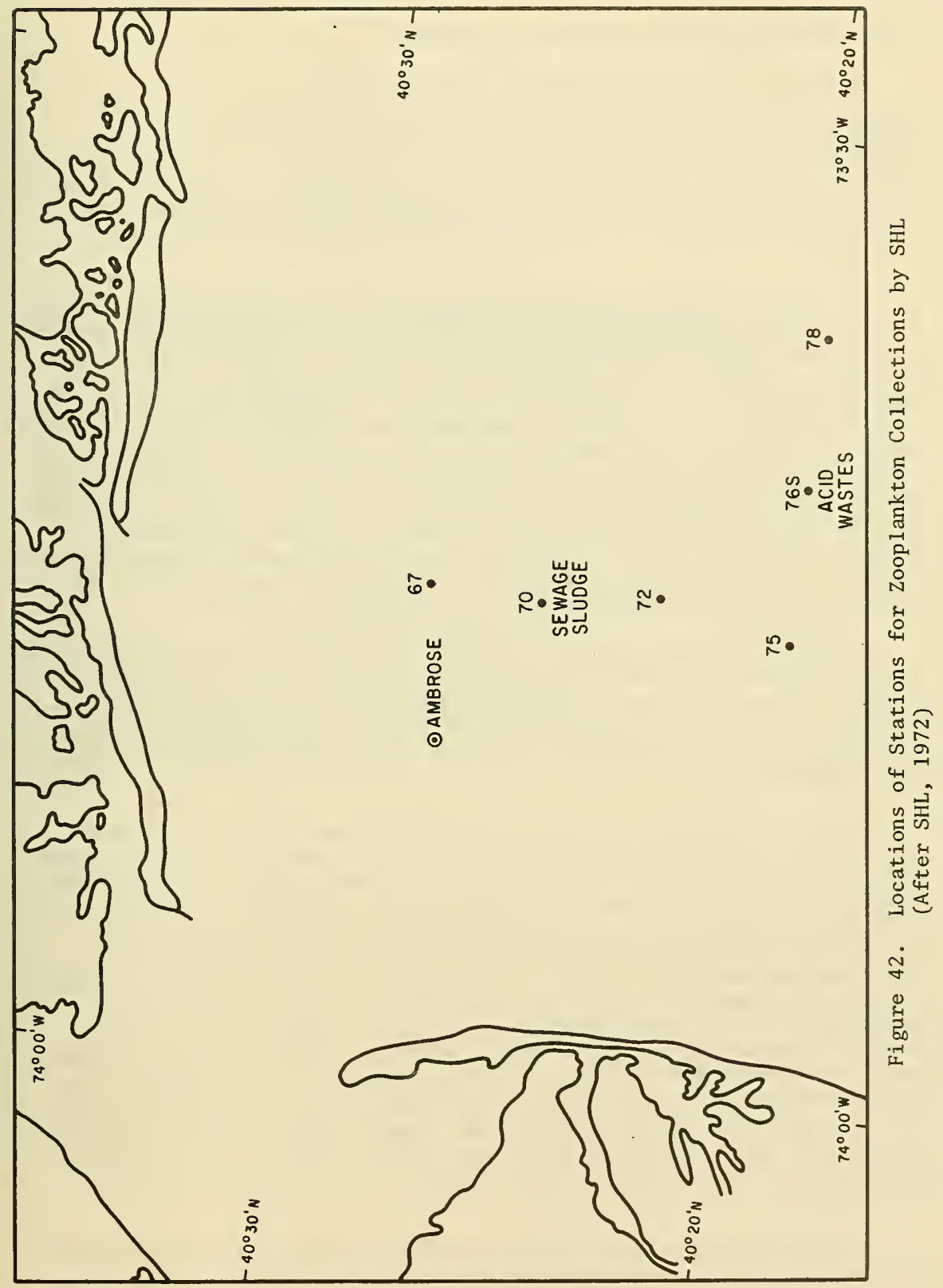


considered the poorest indices of abundance.

In spite of such inadequacies of proper sampling and analysis, the SHL produced interesting qualitative and semiquantitative data for zooplankton populations endemic to the Bight. In these studies SHL emphasized copepods, which are present in the Bight the year round, and are usually the principal constituent of zooplankton. Copepods are sma11 shrimp-like animals, which because of their abundance, are important in the marine food chain. This was the only taxonomic group fully analyzed by the SHL.

The survey showed a general increase in total number of copepods from January until late June, then a decrease from July until October, after which, the numbers again increase. The average number of copepods per cubic meter ranged from a high of 41,000 to a low of 700 . The largest number found was 87,000 copepods $/ \mathrm{m}^{3}$ and the lowest 100 copepods $/ \mathrm{m}^{3}$, with most counts between 1,000 and $10,000 / \mathrm{m}^{3}$. The numbers of copepods $/ \mathrm{m}^{3}$ found by SHL were within the ranges reported by other investigators for other middle Atlantic coastal areas (Table 17). The numerical abundance of six copepod species and the total copepod numbers for each of the six stations and three depths sampled throughout the year, are given in Figures 43 to 48 . Figure 49 gives the average zooplankton population in the water column for the dumping sites and adjacent areas. These data confirm the known seasonal variation of copepod distribution.

A significant observation of SHL was that copepod counts in the sewage sludge disposal area were not different from other areas. Throughout the year the counts of copepods were different only five times. Two of these times the counts were higher than expected, and three times were lower. For the rest of the 93 samples that were analyzed, the counts fell within the expected range.

Besides copepods, other zooplankton organisms were found by SHL in the area of the dumping grounds in significant numbers. These included chaetognaths, polychaete larvae, bivalve larvae and pelagic gastropods. Seasonal zooplankters found in abundance were cladocerans, nauplii and cyprid stages of barnacles, siphonophores, salps and echinoderm larvae. Although important constitutents of zooplankton, these meroplankton organisms are seasonal visitors in the waters of the area, and of limited value in zooplankton studies. Their occurrence however is useful in predicting the potential benthic communities. Bivalve larvae were abundant from January to April and from August through November in 1969, while in January through March of 1970 they were not as abundant. The highest concentration, $8,400 / \mathrm{m}^{3}$ was measured in a bottom sample from an area southeast of the dumping grounds. Counts almost as high of bivalve larvae were taken by SHL in the sewage dumping grounds. The low adult population on the bottom suggested to SHL that settlement of larvae is inhibited.

Polychaete larvae were found in the Bight in densities up to $600 / \mathrm{m}^{3}$, with highest concentrations near the bottom, from January to early June 
Table 17. The Range in Number of Copepods per Cubic Meter Found by Various Investigators in the Coastal Waters of the Middle Atlantic Area.

\begin{tabular}{|c|c|c|c|}
\hline Area & $\begin{array}{l}\text { Range of No. of } \\
\text { Copepods per } \mathrm{m}^{3}\end{array}$ & Net Aperture Size & Reference \\
\hline Block Island Sound & 100 to 8,000 & No. 2 mesh net; $0.366 \mathrm{~mm}$ aperture & Deevey, 1952 \\
\hline Block Island Sound & 5,000 to 30,000 & No. 10 mesh net; $0.158 \mathrm{~mm}$ aperture & Deevey, 1952 \\
\hline Montauk, N.Y, to Bermuda & 100 to 1,000 & No. 2 mesh net; $0.36 \mathrm{~mm}$ aperture & Grice and Hart, 1962 \\
\hline Long Island Sound & 300 to 100,000 & Nos, 2 and 10 silk nets & Deevey, 1956 \\
\hline Raritan Bay & up to 200,000 & No. 12 mesh net; $0.119 \mathrm{~mm}$ aperture & Jeffries, 1959 \\
\hline Sandy Hook Bay & 50 to 600,000 & Hensen silk tow net & Yamazi, 1962 \\
\hline Patuxent River Estuary & 100 to 7,000 & No. 2 mesh net; $0.316 \mathrm{~mm}$ aperture & Herman, et al., 1968 \\
\hline Patuxent River Estuary & 1,500 to 100,000 & $\begin{array}{l}\text { Nos, } 10 \text { and } 20 \text { mesh nets; } \\
0.158 \mathrm{~mm} \text { and } 0.076 \mathrm{~mm} \text { apertures }\end{array}$ & Heinle, 1966 \\
\hline
\end{tabular}




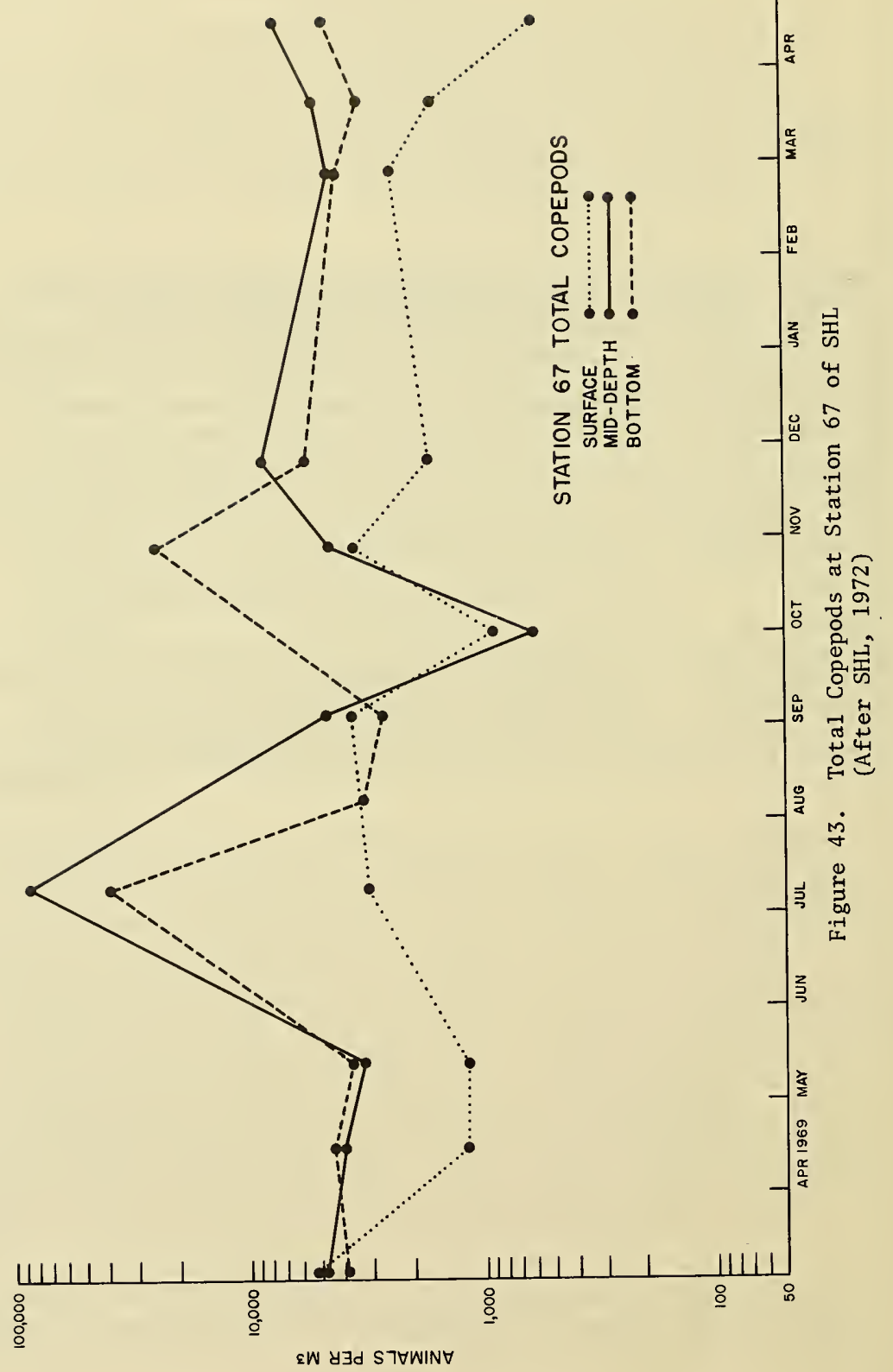




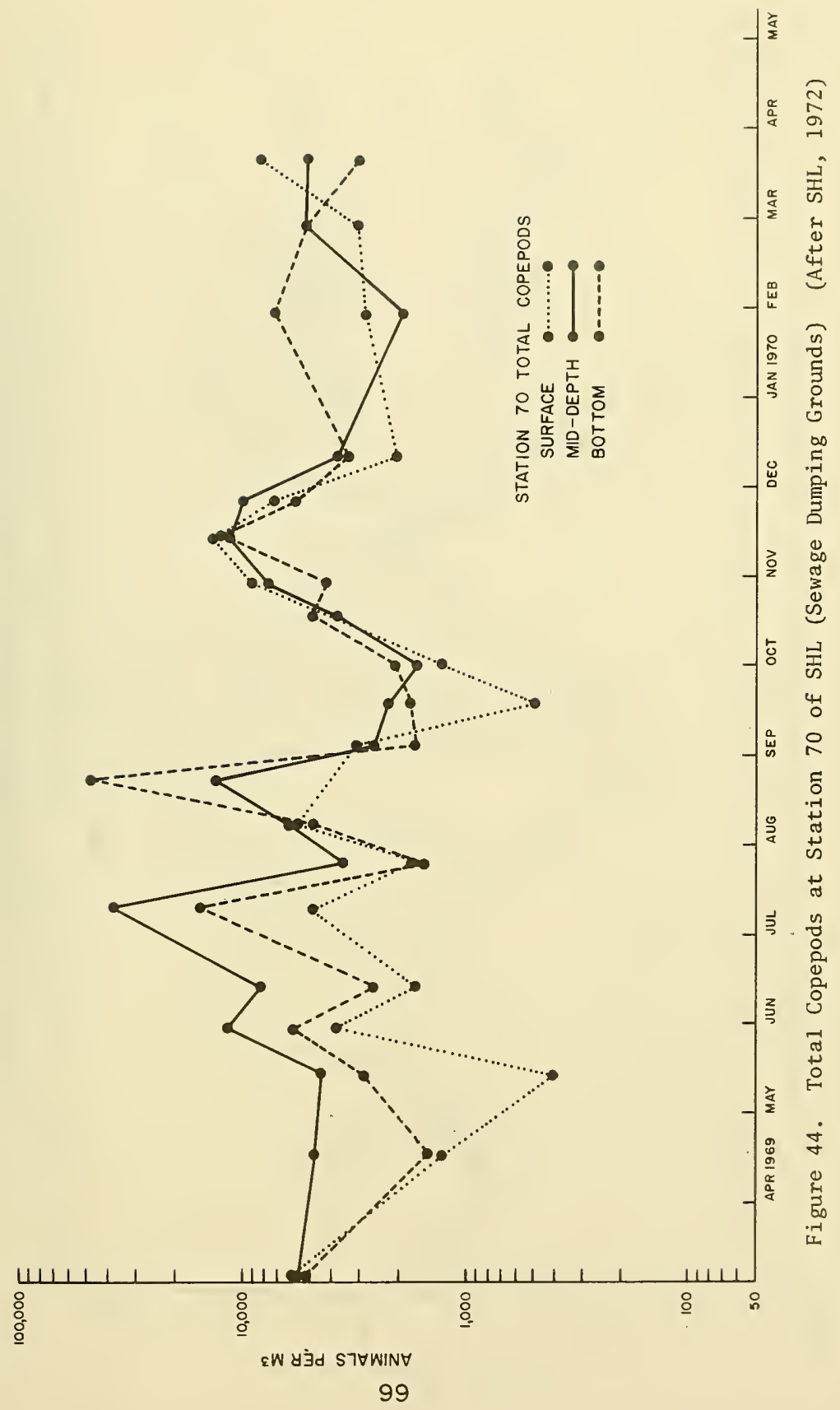




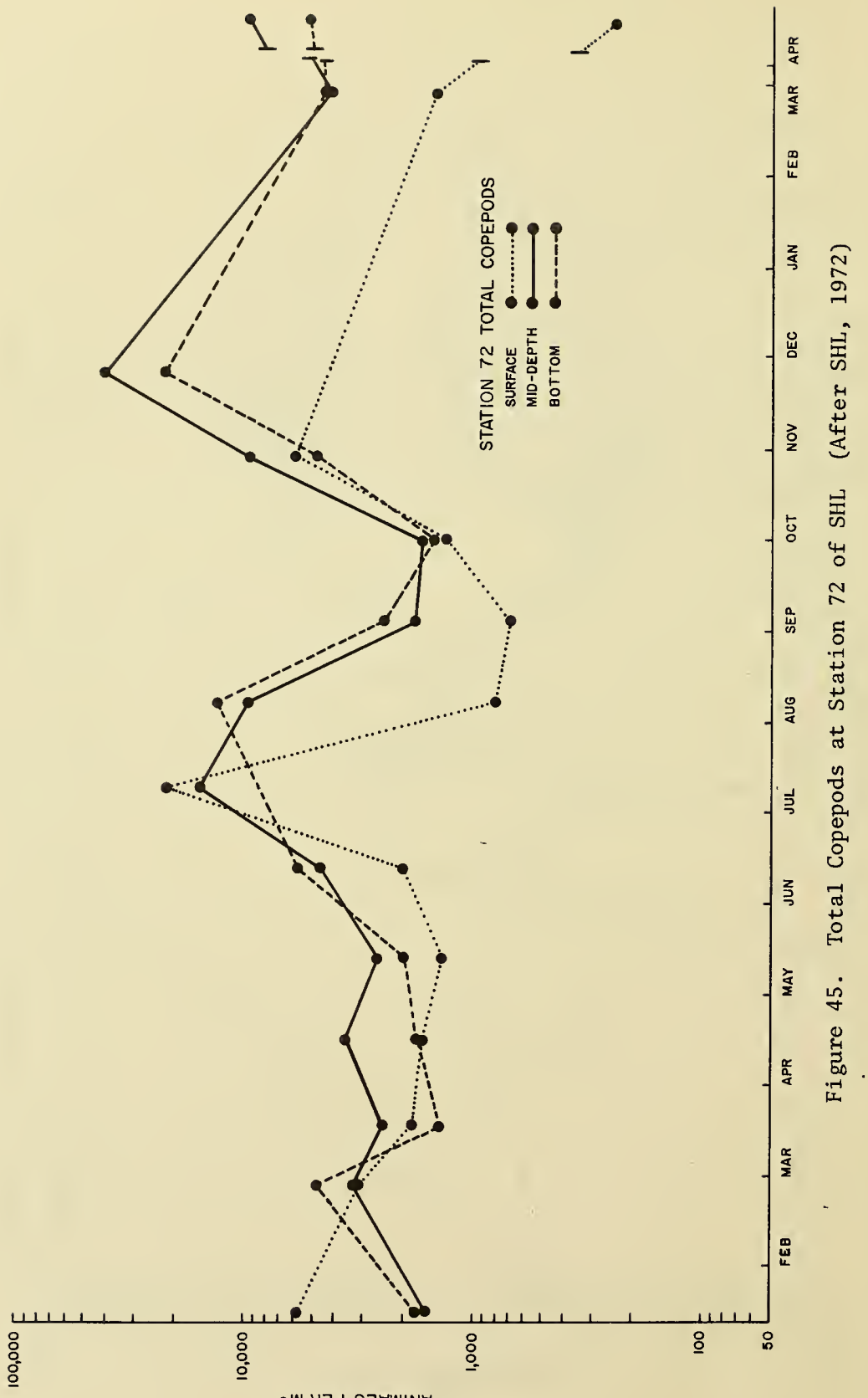

\&W $\forall \exists d$ SרWIN $\forall$

100 


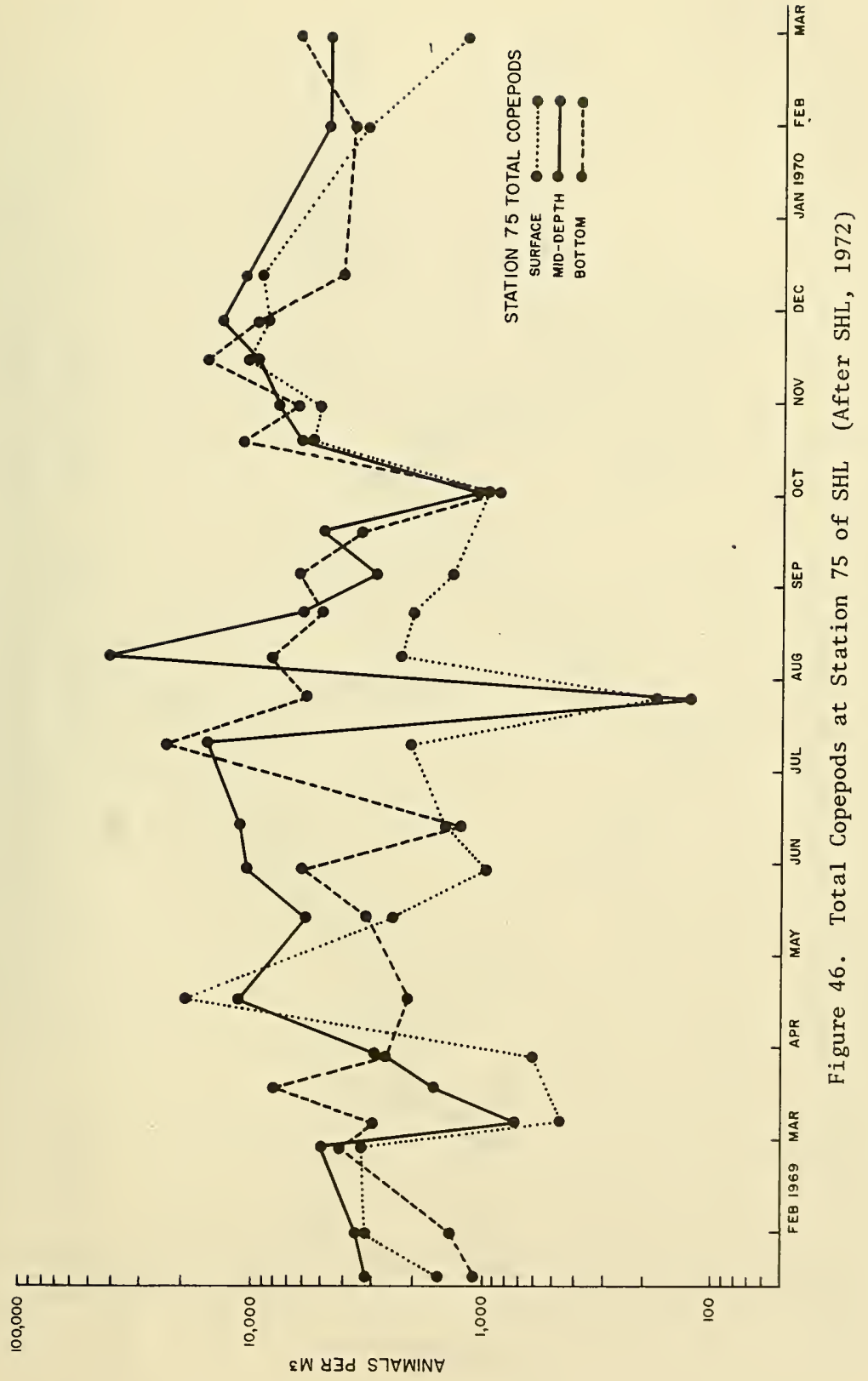




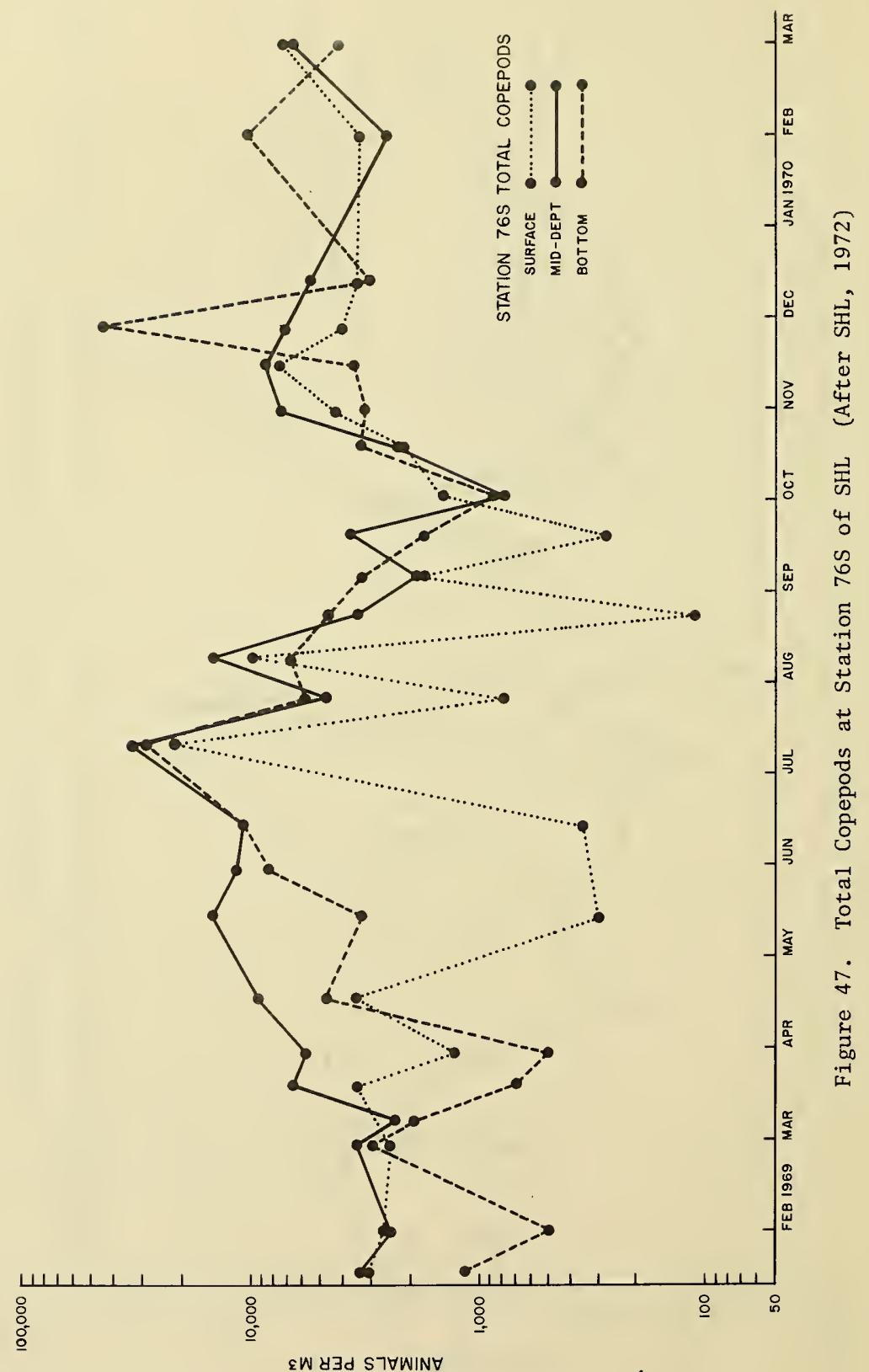




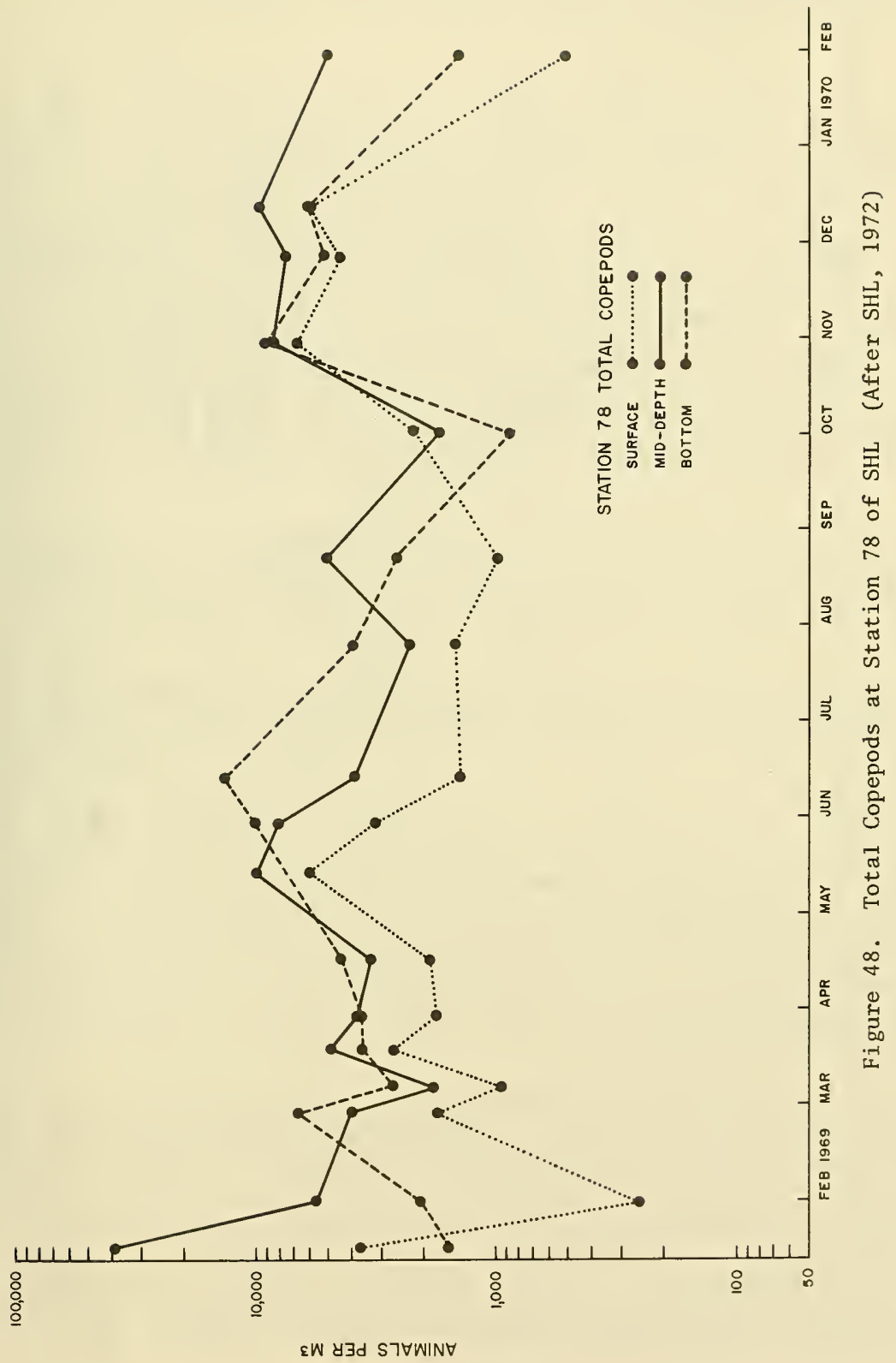




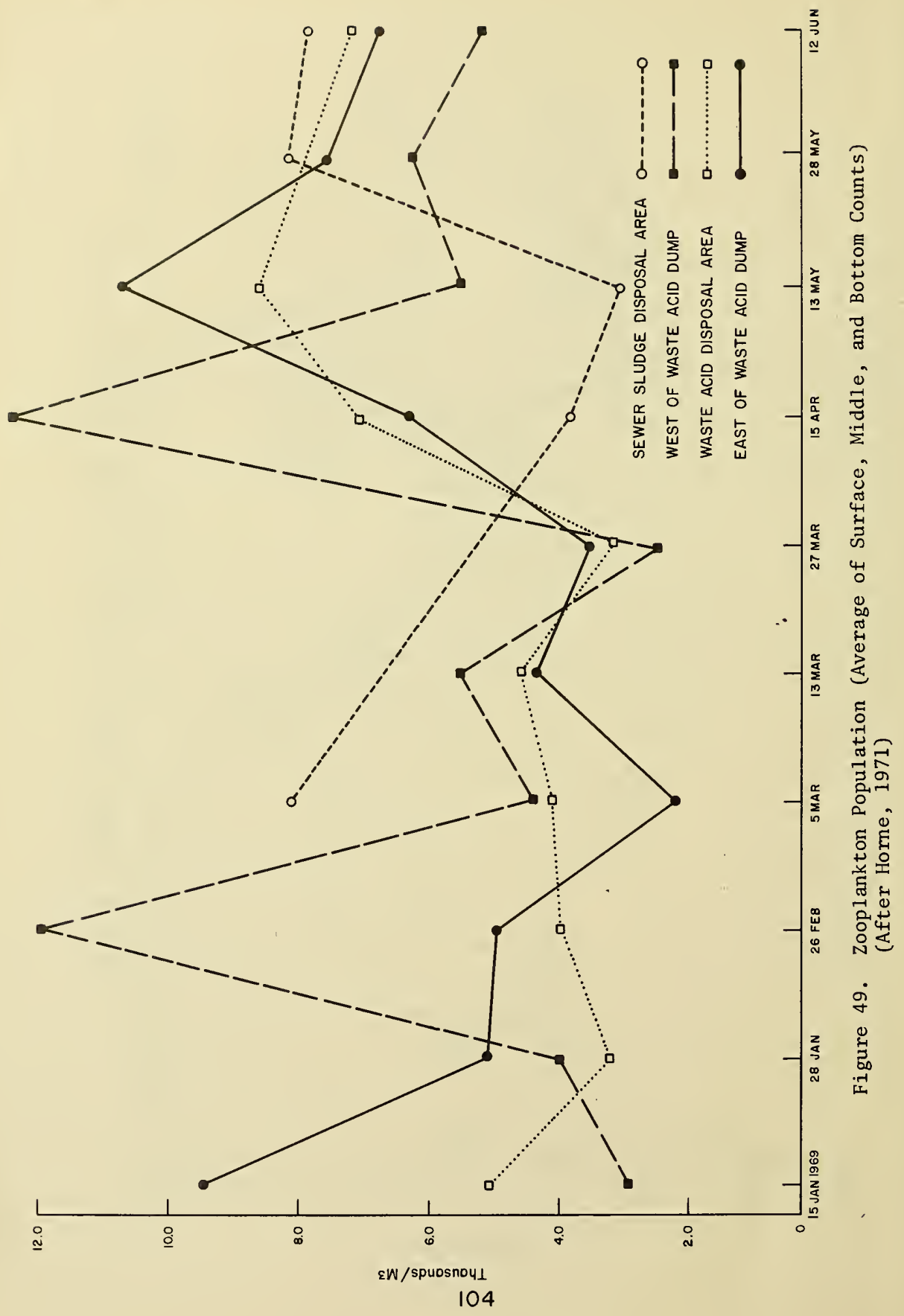


and late August to December. The concentrations of polychaete larvae in the waters of the sewage sludge disposal grounds were similar as those in other stations.

Of the Cladocera, which are small crustaceans, three genera were found in the Bight; Evadne sp., Penilia sp., and Podon sp. Evadne was the most abundant of the three, present in densities of 50 to $\overline{7,000 / \mathrm{m}^{3}}$ from middle May until October. The other two genera were not as frequent, but during July and August, they dominated the zooplankton population. Maximum catches of Podon in the sewage sludge disposal area was $23,941 / \mathrm{m}^{3}$ in $\mathrm{July}$ and for Penilia was $62,570 / \mathrm{m}^{3}$ in August. Because of their infrequency of occurrence, however, Cladocera are not considered important constituents of the total zooplankton fauna. Chaetognatha (arrow worms) one of the most important constitutents of zooplankton because of their predatory habits, were found in the SHL study area throughout the year. Arrow worms were most abundant in the bottom waters and peak concentrations were found from May to July. The highest number taken from a station a few miles southeast of the dumping grounds, was $714 / \mathrm{m}^{3}$. There were no significant differences in occurrence or abundance, between stations.

The pelagic gastropod, Limnacia sp., was present in the SHL study area throughout the year. Its numbers per cubic meter ranged up to 1,780 individuals. The peak number occurred in October 1969, with peaks also in August 1969 and February 1970. Salps, siphonophores and echinoderm larvae were abundant from August to October.

Other organisms, also taken sporadically in small numbers by SHL included larvae of crabs, shrimp, phoronids, barnacles, bryozoans and fish as well as mature forms of amphipods, mysids, pelagic polychaetes, tunicates and hydromedusae.

c. Micro-organisms. Although bacteria in wastes dumped in sea water are rapidly killed, according to Greenberg (1956), certain enteric microorganisms survive in marine muds. It has also been reported by Buelow (1968) that certain pathogenic micro-organisms survive sewage treatment, and could conceivably infect and harm marine life. Still, other microorganisms have a beneficial effect because they induce a rapid and efficient enzymatic breakdown of complex, and possibly toxic, hydrocarbons present in the wastes. No studies have been made however, of micro-organisms in the marine environment of the Bight, other than coliform bacteria.

(1) Coliform Bacteria. The distribution of coliform bacteria is a good indicator for delineating the impact areas associated with ocean dumping of sewage and sewage sludge. Their presence, however, may be temporary. Studies by the Food and Drug Administration (FDA) of the Dept. of Health, Education and Welfare in the vicinity of the dumping grounds indicate that shellfish in this area are bacterially contaminated (Buelow et al, 1968). Samples of shellfish collected peripherally were found to contain unacceptable levels of bacterial pollution. This contamination was attributed to disposal of raw sewage and partially digested sludge outside the prescribed locations, by violators "short dumping." Another 
investigation of the same area however, at a different day, showed reversal of previous high bacterial counts indicating that "short dumping" does occur, but sporadically.

Based on a 1966 shellfish program study, undertaken initially by FDA, involving water sampling and the awareness of possible "short dumps," an area of 6-mile radius around the sludge dump site has been closed to shellfishing. Recently, other areas of the Bight have been closed by FDA to the harvesting of surf clams because of poor water quality. Whether the deterioration of coastal water quality is the result of ocean dumping has not been documented. Well planned analyses of the coliform bacteria content of shellfish from areas adjacent to the dumping sites is pertinent and should be continued (SAC, 1972).

Buelow et al, (1968) took counts of coliform bacteria in stored sludge, prior to disposal. Such counts showed total coliforms in excess of $2.4 \mathrm{x}$ $10^{9}$ per $100 \mathrm{ml}$, and fecal coliforms varying from $4.3 \times 10^{5}$ to more than $2.4 \times 10^{9}$ per $100 \mathrm{ml}$.

SHL surveyed for coliform bacteria in the Bight, and found dense populations of bacteria inside the sludge and spoil beds with decreasing numbers away from the disposal areas (Fig. 50). The source of these bacteria, according to SHL was ocean dumping rather than outflow of polluted Hudson River or estuarine waters.

These values are high but considerably less than the values in stored sludge reported by Buelow, and considerably less than some counts taken in the Lower Bay of New York Harbor. The distribution of bacteria showed little seasonal variation within each disposal area, suggesting correlation with the dumping activities. The bacterial densities present a distribution consistent with the dumping activity and the mixing and dispersion patterns of the waters in this area (SAC, 1972).

(2) Pathogens. SHL suggests that the existence of coliform bacteria in the sediments and the waters of the Bight means also the existence of pathogenic bacteria which may have a harmful effect on marine life. No attempts have been made by SHL or any other investigators to confirm and identify pathogenic bacteria in the area. Identification studies are time consuming and difficult, but necessary in establishing whether disease is transmitted in the marine environment of the Bight.

(3) Other Micro-Organisms. Waste materials dumped in the Bight are suspected to contain a large amount of petrochemicals. In these petrochemicals, complex organic compounds may be included which may not be biodegradable. If such organic compounds, particularly the "heavy end" fractions made of large cyclic hydrocarbons, cannot be degraded and are uptaken in the food chain, serious marine biological damage could occur. Not only may these compounds be carcinogenic in character, but they may also be interfering with chemical signals that are often necessary in the marine predator-prey relationships. None of the investigations in the Bight has yet included studies of Penicillium, Nocardia, Microccoccus, 


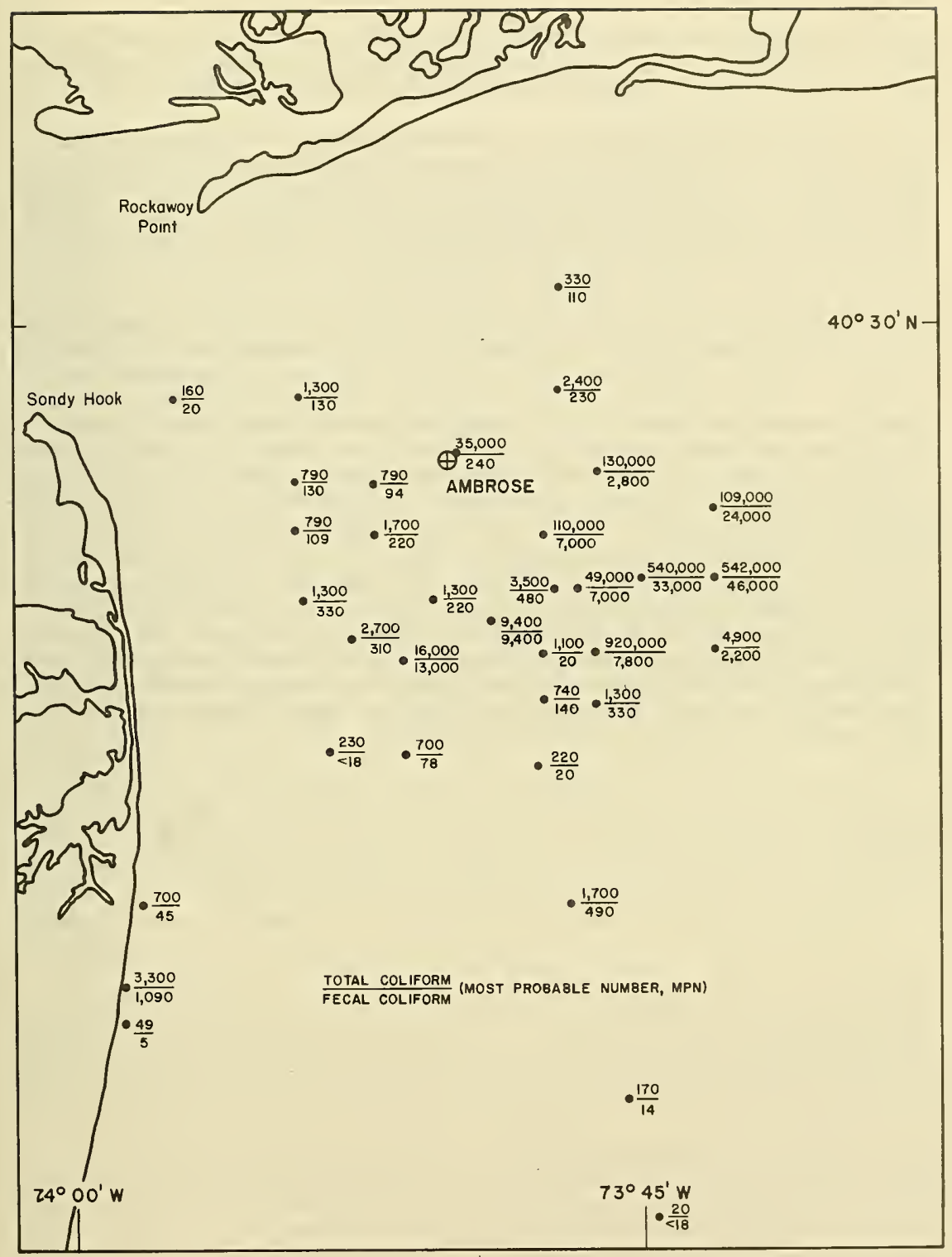

Figure 50. Analysis of Coliform in Sediment Through December, 1971 
Candida or other hydrocarbon-degrading organisms. Such organisms are known to attack and break down, emzymatically, components of petrochemicals such as olefins, napthas, and other organic compounds.

d. Food Chain Studies. To determine how toxic materials may be taken up by marine organisms, a better understanding of the marine food chain and basic predator-prey relationships of marine life in the Bight is necessary. Biological studies have not yet shown the extent of the temporal and spatial effects of ocean dumping on commercially valuable marine species in areas outside the dumping grounds.

The results of the stomach content analysis of fishes performed by SHL indicated that yellowtail flounder, winter flounder and ling ingest primarily benthic organisms, such as polychaete worms, amphipods, and bivalves. Whiting appear to feed primarily on epibenthic and swimming organisms such as mysids, sand shrimp, and fish. Less than 5 percent of the fishes that were sampled in the area of the dumping grounds contained in their stomach such sewage-sludge artifacts as hair, band-aids, and cigarette filters. Whether ingestion of these materials is selective or accidental during normal feeding, is now known. Yellowtail flounders sampled in the sewage dumping grounds contained in their stomachs up to 25 percent sand and gravel, and since these are not food resources, it can be assumed that fish ingest foreign materials accidentally. The number of fish ingesting such materials, however, is small and may not be too objectionable, except esthetically. More important, however, is ingestion of materials that include heavy metals and pathogenic microorganisms. Whether such ingestion of harmful materials occurs, and to what degree, is not known with certainity. 


\section{SECTION IV. DISCUSSION}

1. Dispersion and Movement of the Waste Materials

The dispersion of waste materials, following disposal at the dumping grounds, is difficult to study because of the variable and complex hydrographic conditions prevailing in the Bight which were discussed earlier. A number of hydrographic investigations of the Bight have been made. Limited studies on rates and patterns of dispersion of waste materials dumped in the Bight have been conducted by Ketchum and Ford (1948), Redfield and Walford (1951), Beyer (1955), Saila (1968), Buelow (1968), and more recently, by the SHL (1972). None of these investigations has been synoptic or has considered adequately the total circulation effects on waste dispersion.

Settling of waste material depends on many physical factors. Although most of the waste settles to the bottom rapidly, a large percentage of the finer material remains suspended in the water column. Saila (1968), in his studies of dredged sediment dumping in Rhode Island Sound, found that two slicks of fine waste material tend to form within an hour of dumping. One slick was at the surface and another at roughly mid-depth, at the density gradient of the thermocline. A thermocline, however, is not a permanent feature of the waters of the Bight. During winter, the thermocline is absent and the waters become vertically homogeneous. In winter, therefore, only one slick of very fine material may be observed in the surface waters. Depending on circulation and turbulence, this finer waste material may stay in suspension for a long time and may be transported from the disposal area.

Mixing and dispersion of the waste materials in the upper layer of the ocean (0-50 feet in thickness) is affected by wind driven and tidal currents. Also, fine material that has settled to the bottom may go into suspension as a result of storm waves or strong bottom currents, and move laterally. Knowledge of surface and bottom circulation is essential in assessing the dispersion and movement of the waste materials following disposal or settling.

The SHL attempted to determine surface and circulation of waters in the general areas of the dumping grounds. To accomplish this objective, SHL utilized current meters and surface and seabed drifters. Unfortunately only three of the four current meters that were used in this investigation by the SHL gave satisfactory records, and then for only limited periods.

The use of drifters is the most economical method of studying qualitatively net water-mass movements. It is assumed that the reaction of the drifters to water movements closely approximates that of other small movable objects at the surface and near the bottom. According to the SHL report, drifter behavior provides the best estimate of the effect of water movement on the transport and dispersal of waste materials. This assump- 
tion may be questionable since small grains of sediment cannot be expected to behave in the same manner as drifters of large surface area and variable buoyancy.

As mentioned earlier, of 1,886 surface drifters released by the SHL, 497 (26 percent) were recovered. Of 2,190 seabed drifters released, 710 (32 percent) were recovered. The surface and seabed drift studies conducted by the SHL indicate qualitatively a general circulation pattern for the Bight. These data and analyses were summarized in the results section by reporting the percent drifter recovery from the various release locations, but not on the basis of specific shore recovery locations. Such data would have been more informative (SAC, 1972).

Based on recovery of its drifters, SHL concluded that there is a substantial shoreward migration of surface and bottom drifters, since over 29 percent of all the drifters released found their way to shore. SHL also suggested that its data indicate a strong flow at the bottom along the axis of the Hudson-Ambrose Channel into the mouth of the Hudson Estuary. This pattern of circulation is partially supported by a drifter study of the middle Atlantic Bight area conducted by Bumpus (1965). This study indicated that nearshore, the tendency for the flow was in a westerly or southerly direction with a component toward the coast; but Bumpus concluded that the onshore-offshore component was difficult to distinguish from, more or less, isotropic dispersion because only those drifters carried onshore yielded any information. His study, like that of Harrison et al, (1967) indicated that there is a definite residual bottom drift towards the mouths of estuaries. According to the SHL report (SHL, 1972), such inflow to the Hudson Estuary mouth is expected as a normal consequence of estuarine circulation driven by fresh water outflow, and has been widely observed in other situations (Conomos et al., 1970; Gross, Morse and Barnes, 1969).

As indicated earlier, under tidal circulation the ebb in the Lower Bay is generally stronger than the flood by 10 percent or more, and a net transport of water moves outward from the Hudson Estuary. The quantity of water entering Lower Bay is limited, and waste material in suspension in this water mass would be too diluted to be of concern. It is doubtful that ocean dumping affects significantly the quality of the waters of the Lower Hudson Estuary.

Another conclusion of the SHL study is that there is a general clockwise circulation in the Bight. Such clockwise circualtion has been also observed by Bumpus and Lauzier (1965). There is no basis however for the suggestion in the SHL study that this type of circulation can be associated with bifurcation in the head of the Hudson Channel. Finally, while surface drift patterns obtained by the SHL suggest strong seasonality, there was only mild seasonal variation in the bottom returns. During winter, surface flow in the Bight appears to be predominantly to the southeast, away from the coast. At other time flow tended northwards Long Island (SHL, 1972). 
According to the SHL report, patterns of circulation obtained from its drifter studies indicate a transport mechanism which can account for the distribution of organic material, coliform bacteria, and heavy metals found in the sediments and waters of the Bight. This claim, however, is disputed. According to the SAC review (SAC, 1972), the SHL study did not incorporate the findings of the water circulation patterns, preliminary as they may be, in an analysis of the distribution of important constituents of the discharged waste in either the water column or the benthos. The information on circulation, therefore, cannot be correlated with conclusions on quality conditions. The SHL water-circulation study, for example, cannot explain the existence of the area east of the dumping grounds which has carbon-rich sediments, but is separated with no continuums from the disposal area. Similarly it cannot quantify the degree of dilution and dispersion these waste constituents undergo, if indeed their transport is in the directions indicated by the drifters.

The circulation data accumulated from the Bight is insufficient to permit quantitative studies of waste dispersion. Results with seabed and surface drifters, although of some value in indicating net surface and bottom movements of the water, are of questionably validity. The actual path of these drifters and time of travel are not known, and their net movement cannot be correlated to sediment transport and water quality. Return of drifter to shore is not necessarily proof that harmful pollutants will also end up on shore. The path of the drifters is not direct, and the time of travel is long. Even if pollutants are assumed to follow the same path as the drifters, the degree of dilution to surrounding waters will be great, reducing adverse effects on water quality.

The dispersion studies of the SHL would have been more meaningful if the study of the hydrography of the Bight was supported by geostrophic flow calculations. Also a direct comparison of surface drift with magnitude of the annual wind stress in different directions, would have been helpful. In a study of surface currents off the Oregon Coast (Wyatt et al, 1972), wind stress data was correlated effectively with surface currents and net water transport.

Although the SHL studies of the water circulation have not been sufficient to correlate with waste dispersion following dumping in the Bight, the current measurements obtained, provide a basis for further study, such as a time series analysis. In conjunction with the drift studies, such an analysis (SAC,1972), would indicate, at least in a preliminary fashion, the circulation pattern of the area, and the significance of the various factors affecting the circulation. Specifically, it would help define the variance of the different inputs. This is important in respect to effects of transport processes of the system in distributing the wastes throughout the Bight. Additional analysis of these data would be an important input to a preliminary hydrodynamic model of the area which could correlate effectively water circulation data with the temporal and spatial distribution and transport of waste constituents. Such a model should incorporate dispersion and advection terms, reactions that affect the 
concentration of waste materials, mass input rates, and pertinent biological, chemical and physical characteristics. Finally, this model would help provide specific answers to such problems as long term accumulation and equilibrium, and would help assess alternate plans for the improvement and maintenance of water quality in the Bight area (SAC, 1972).

In summary, the extent of dispersion and movement of waste materials in the Bight is closely related to water circulation. Water circulation studies, such as those by SHL, using surface and bottom drifters are useful in indicating only the onshore component of net water transport and cannot be correlated effectively to isotropic dispersion, seasonal variances, or tranport mechanisms of waste materials. Similarly, drifter studies cannot help in quantifying dispersion of wastes or be correlated to water quality without considering travel time and degree of dilution of wastes. The apparent absence of a thick waste layer in the present dumping grounds suggests rapid degradation and assimilation of the organic constituents of the waste or a mechanism of transport operates for both organic and inorganic fractions. Lateral dispersion of the waste materials occurs to the north and to the south of the dumping grounds is evidenced from the distribution of carbon and heavy metals in the sediments. The quantities, if any, of the fine waste materials which may reach the shore are not known with certainty. Their degree of dilution is such that no significant adverse effects on coastal water quality are expected.

Chemical data indicate that waste materials are transported downward into the upper part of the Hudson Gorge. The quantities of waste material moving downward have not been determined. Bottom currents and gravityinduced turbidity currents may be transport agents. Better knowledge of the bottom and surface circualtion of this area is required to determine the dispersion patterns and the ultimate fate of waste materials in the Bight.

\section{Effects of Ocean Dumping on Water and Sediment Characteristics}

It is difficult to assess the possible effects of ocean dumping on water and sediment quality because of the interrelation of the many key variables. A change in the concentration of any variable, may lead to subsequent change in many others in an attempt to restore chemical equilibrium. Similarly, biological cycles may affect many of the water and sediment quality variables in a non-linear and unpredictable fashion.

It must suffice in this report to discuss only those water and sediment quality parameters that may be most readily affected by ocean dumping, and to compare them with desired water quality conditions or with natural or original characteristics of the undisturbed marine environment. Water quality criteria are based upon scientific determinations of the specific characteristics of water which would permit the appropriate uses agreed upon by the States and the Environmental Protection Agency. At present, these criteria are based on existing information, but are subject to change, review, and improvement as additional knowledge is obtained. 
Water quality criteria may vary from State to State, and even within a single State, reflecting natural conditions and the intended use to be made of the receiving water. The standards include criteria for the physical and microbiological properties of water and the inorganic and organic chemicals. These water properties, constituents, and pollutants, are described by parameters such as turbidity, settleable and dissolved solids, temperatures, pH, coliform bacteria, dissolved oxygen, toxic substances, chemicals, and oil. The desired standards vary according to the intended use of the water body, whether it is for recreation, navigation, fish and wildlife propagation, or drinking. No similar standards exist for the quality of sediments, even though cumulative effects may change this quality drastically over the long term.

Chemical criteria should be used with care. Chemical properties are indicative of water quality at the time of sampling, and are not indicative of past or long-term conditions. Similarly, their use as indices of environmental stress may be misleading, since their presence is not static. According to Butcher (1955), environmental stress can be best judged by determination of biological conditions rather than measurement of chemical properties. The absence of established criteria on water quality may necessitate the use of biological indicators. Such indicators may not be sensitive enough to respond to dynamic short-term water quality changes, and their use may be misleading. A combination, therefore, of chemicalbiological indices may be more appropriate. In the Bight, it can be safely assumed, continuous ocean dumping has resulted in static water and sediment conditions, and the use of biological indices may be justified.

Two basic differences between water quality standards and sewage effluent discharge limitations should be briefly explained. Water quality standards apply to the natural aquatic environment of, and conditions within, a body of waer; effluent discharge limitations apply directly to the characteristics of wastes at the point of discharge into a larger water body. Ocean dumping acitivies fall under the latter category. The dumping grounds of the Bight can be considered as a mixing zone which, (by EPA definition) is an area that may be unaviodably polluted by mixing of discharged waters with the receiving waters. Materials discharged at the dumping grounds are not all liquid, but the analogy holds. According to EPA, (EPA, 1972) mixing zones have defined and identifiable limits, and the waters outside of the zones must meet the standards for that particular body of water. No provision has been made for water and sediment quality limits within the mixing zone, but it is generally assumed that concentrations of certain chemical species far exceed permissible limits of other aquatic environments.

Water and sediment characteristics of the Bight waste disposal grounds and surrounding water are influenced directly the the character of the waste itself. As expected, mechanical dilution and mixing of these wastes with sea water and sediments, significantly reduce concentrations of certain constituents. Even though the volume of the receiving waters far surpasses 
the volume of the dumped waste, certain chemicals exist naturally in such minute amounts in the receiving waters, that their concentrations are greatly affected by the concentrations in the wastes. Additionally, sediment and water quality characteristics of the area may be affected, over the long term, by chemical reactions at the sediment-water interface. Such reactions could lead to temporal and spatial changes in the aqueous concentrations of various chemicals. Resulting changes would be difficult to assess without continuous and far more extensive studies than those completed in the New York Bight.

The work by SUNY-SB and SHL on the chemical characteristics of the wastes following deposition should be regarded as preliminary and largely inconclusive (SAC, 1972). A large part of the water chemistry conducted by the SHL on phosphorus, nitrate, total iron, dissolved oxygen, chorophyl1$a$, and heavy metals, is presented in relatively undigestive form. Both the SUNY-SB and SHL studies show differences in the size and shape of the waste disposal areas, suggesting that the uses of total carbon distribution or percent organic content are inadequate to define the lateral extent of the waste deposits (SAC, 1972). The boundaries of the disposal areas are diffuse and are difficult to determine. A better method might have been used. Sediment particle size distribution, for example, would have been more helpful in mapping the disposal areas. An adequate coring program, and a study of the vertical distribution of heavy metals might have been more appropriate in defining the depth of the waste deposits.

Regardless of the indicated limitations of the chemical studies in the Bight, it can be safely concluded, in qualitative terms, that ocean dumping has changed the water and sediment characteristics of the dumping grounds and adjacent areas, and that measured concentrations of certain variables, especially heavy metals, bacteria and organics, exceed EPA permissible limits. The adverse effect is more pronounced near the bottom-sea interface.

In the following sections, individual water and sediment quality characteristics in the Bight are discussed in relation to the effects of ocean dumping in the area.

a. Temperature. Temperature standards have been set to control manmade temperature changes in closed bodies of water. No maximum water temperature standards have been set for the open coastal environments, but the National Technical Advisory Committee of EPA (NTAC) in its report (EPA, 1972) recommends that monthly maximum daily temperatures, not be raised by more than $4^{\circ} \mathrm{F}$ from September through May and by no more than $1.5^{\circ} \mathrm{F}$ from June thorugh August. Waste disposal in the Bight has not created any known water-temperature problems. The relatively small volume of the wastes and rapid dispersion and dilution preclude any lasting temperature effects on sediment and water quality.

b. pH. Water quality standards for acidity or alkalinity are expressed by an index of the hydrogen ion activity $(\mathrm{pH})$ which is an indicator of these properties and not a measure of either. 
Acidity in the natural marine environment is caused by carbon dioxide, mineral acids, weakly disassociated acids, and the salts of strong acids and weak bases. Alkalinity on the other hand is caused by strong bases and the salts of strong alkalies and weak acids. In natural waters, the $\mathrm{pH}$ falls in a range between 6.5 and 8.5 , but it is sometimes increased by photosynthesis.

The permissible $\mathrm{pH}$ range for the coastal waters of New York and New Jersey, according to water quality criteria (EPA, 1972), should be from 6.5 to 8.5 . The $\mathrm{pH}$ range observed in the vicinity of the dumping grounds of the N. Y. Bight, ranges from 7.10 to 8.40 , and does not exceed the prescribed limits. The only drop in $\mathrm{pH}$ would be observed in the waters of the acid dumping grounds, immediately after an acid dump. The low $\mathrm{pH}$ value in this area would occur for brief periods. As discussed earlier, Redfield and Walford (1951), have shown that the $\mathrm{pH}$ of the water from the wake of an acid dumping barge was above 6.0 in all samples collected more than 3 minutes after dumping and a $\mathrm{pH}$ of 7 was reached about 3.5 minutes after dumping.

c. Turbidity. The National Technical Committee (NTAC) of EPA has not set Iimits on turbidity for oceanic bodies. For lakes, NTAC recommends that turbidity in the receiving water due to a discharge should not exceed 25 JTU (Jackson Turbidity Units) in warm water lakes, and 10 JTU in cold or oligotrophic lakes. No provision for turbidities has been included in the water quality standards of the States of New York or New Jersey.

Turbidity within the dumping area of the Bight is caused by fine suspended matter such as clay, silt, and finely divided organics from sewage sludge, and dredge spoils. In addition, disposal of acid wastes in the acid dumping grounds results in a ferric hydroxide floc, observed as a stain in the waters, which also increases turbidity. This material eventually settles to the bottom or is rapidly dispersed. A decrease in turbidity would be observed for the waters of the dumping area were it not for the continuous dumping. Turbidity would be expected to vary over the short term, depending on the quantities being dumped, frequency of dumping, and local and seasonal weather conditions. Over the long-term, turbidity would be expected to become static. Static turbidity conditions in the dumping grounds and adjacent areas, would reduce light penetration into the water and result in a reduction of photosynthesis by phytoplankton organisms and attached or submerged vegetation. This effect on primary productivity has not been quantified for the disposal areas of the Bight, but it does not appear to be significant. Other environmental variables such as nutrient addition, may be partially compensating for the loss in primary preductivity due to turbidity. Turbidity associated with ocean dumping does not appear to have an adverse lasting effect on the sediment and water quality of the Bight. Possible adverse effects on marine benthic life are discussed in a subsequent section of this report.

d. Dissolved Solids. The water quality criteria report of EPA (1972) recommends that dissolved solid concentrations in the water should not 
exceed 500 milligrams per liter $(\mathrm{mg} / 1)$. This is a measure, however, applicable only to drinking water supplies. For the protection of freshwater fish, the EPA criteria specify that concentrations should not exceed $50 \mathrm{milliosmoles}$ (the equivalent of $1500 \mathrm{mg} / 1 \mathrm{NaCL}$ ). No similar limits have been given for offshore bodies of water, such as the dumping area of the N. Y. Bight.

Natural seawater contains dissolved solids consisting primarily of chlorides, carbonates, bicarbonates, nitrates, phosphates, sulfates and traces of metallic elements. Concentrations or effects of these substances can sometimes be elevated or synergistically altered by the addition of chemical substances (such as those contained in the wastes) resulting in deterioration of water and sediment quality and local adverse effects on fish and other aquatic animals.

The wastes dumped in the Bight, especially sewage sludges, contain dissolved organic and inorganic solids which may add materially to naturally occuring concentrations of certain substances already in solution, and also introduce some new ones. The quantities of such dissolved solids in the wastes have not been determined. However, not all the solids go into solution immediately after dumping as their solubilities are governed by a number of physical and chemical factors, such as temperature, $\mathrm{pH}$, oxidizing or reducing conditions, and saturation limits. Furthermore chemical breakdown of certain solids constituents of the wastes, over the long term, could produce unknown water-soluble by-products. Reactions could be reversed, and materials may be removed from the liquid state, returned to the solid state, and deposited as sediments. The chemical equilibria affecting such interactions are too complex to be quantitatively described. However, a general estimate of total dissolved solids in the waste materials disposed in the Bight could be obtained.

Discussions of individual chemical species, such as nutrients, heavy metals and organic substances that may go into solution, and therefore affect water and sediment quality, are given in subsequent sections.

e. Settleable Solids. Settleable solids include inorganic materials such as sand, silt and clay, and organic materials such as greases, oils, tars, animal and vegetable fats. Sewage sludges, dredge spoils and industrial wastes fall within these categories. The NTAC of EPA (EPA, 1972) has recommended that no settleable solids be added to these waters in quantities that adversely affect the natural biota. The States of New York and New Jersey have similar descriptive restrictions (EPA, 1972). None of these restrictions apply to ocean dumping, even though ocean dumping constitutes the largest single source of solids entering theNew York Bight (Gross, 1970). Although the damage to the benthic biota due to the smothering effect of setteable solids associated with ocean dumping is evident, the dumping grounds of the Bight may be thought of as a trade-off area, or as a mixing area where settleable solids may be temporarily allowed to exceed permissible limits, until an alternate solution to the problem of waste disposal is found. 
f. Dissolved Oxygen. The water quality criteria, used by EPA, recommended a minimum dissolved oxygen (DO) concentration of 5 milligrams per liter $(\mathrm{mg} / 1)$ in open coastal waters, and $4 \mathrm{mg} / 1$ in estuarine and tidal tributaries excepting waters with naturally despressed DO (EPA, 1972). Similarly, both New York and New Jersey have a lower limit of $5 \mathrm{mg} / 1$ for ocean waters at any time, while the lower permitted limit for the waters of the New York harbor is $2.5 \mathrm{mg} / 1$. These values however, do not differentiate between the DO of bottom and surface water and are average values for the water column.

Dissolved oxygen is a water quality property that can also affect the quality of the sediments. Dissolved oxygen enters seawater through atmospheric re-aeration and algal photosynthesis. Its concentration is influenced by a number of variables, such as mixing conditions, primary production, the vertical and horizontal distributions of temperature and salinity, and the biochemical oxygen demand. Certain minimum concentrations of DO are required to support populations of aerobic organisms at all 1 ifedevelopment stages. Oxygen is also important in the aerobic decomposition of organic materials. In the presence of oxygen organic matter undergoes biological decompisition to yield $\mathrm{CO}_{2}$ and $\mathrm{H}_{2} \mathrm{O}$ which are substances necessary to sustain life. Changes in the dissolved oxygen of the water may result in changes in photosynthesis and the primary productivity of an area. Reduction in DO, for example, can result in the development of anaerobic conditions with associated water odor problems, and the destruction of aerobic marine animal life, such as commerically valuable finfish and shellfish.

Decay of organic matter in the sea may release $\mathrm{H}_{2}, \mathrm{H}_{2} \mathrm{~S}, \mathrm{CH}_{4}$ and $\mathrm{NH}_{3}$, which are undesirable substances. The organic materials in the sediments of the Bight dumping grounds exert a biochemical oxygen demand (BOD) which reduces the DO near the bottom. According to Torpey (1967) oxygen depletion can occur in the following sequence.

a. When oxygen demand of pollutants reaches $20 \mathrm{lbs} 0_{2} /$ day/acre, instability develops, the oxygen level drops sharply, and fish migrate.

b. When the pollution loading level demands 20 to $132 \mathrm{lbs} 0_{2} /$ day/ acre the dissolved $0_{2}$ remains substantially constant at between 25 to 50 percent of saturation. This plateau is homeostatic because symbiotic algae and bacteria are able to maintain this $0_{2}$ level.

c. At extremely high loading rates when demand exceeds $1321 \mathrm{bs}$ $\mathrm{O}_{2}$ /day/acre, the $\mathrm{O}_{2}$ is exhausted and anaeorobic conditions develop.

A BOD range from 16 to $330 \mathrm{gm} \mathrm{O}_{2} / \mathrm{kg}$ of volatile solids has also been determined by Isaacs (1962). The BOD of highly polluted sediments can be, therefore, several orders of magnitude above the DO saturation level. Moreover this demand can be continuous or deferred for some future time when oxygen again becomes available. Such demand probably removes all the oxygen from the interstitial water so that chemical reactions in the sedi- 
ments below the surface proceed under anaeorobic conditions, while at the sediment-water interface, conditions may still be aerobic. This may have a significant influence on other water quality properties.

Under aerobic conditions, some chemical elements exist in their oxidized states. Iron and manganese can be found as insoluble $\mathrm{Fe}_{2} \mathrm{O}_{3}$ and $\mathrm{MnO}_{3}$; phosphorus as insoluble $\mathrm{FePO}_{4}$; nitrogen and sulfur as nitrate and sulfate. Under anaerobic reducing conditions, the ferric ion would be reduced to ferrous iron; phosphate may be released from the sediments; and nitrates and sulfates will be reduced to ammonia and sulfide. The chemistry of other chemical species may be also affected by oxidizing or reducing conditions. Temperature, salinity and turbidity also affect dissolved oxygen. The saturation levels of DO are particularly influenced by the vertical and horizontal distribution of temperature and salinity, and both fluctuate widely near the dumping grounds.

During summer, the thermocline is more pronounced, and surface waters contain a higher concentration of oxygen, because of reaeration, wave action, and photosynthesis. Below the thermocline, lack of photosynthesis and the increased BOD of the wastes could significantly reduce the dissolved oxygen. Such a drop in oxygen content of near-bottom waters over the dumping area was reported by the SHL. Measurements of DO taken by SHL fluctuated between $2.0 \mathrm{ml} / 1$ iter to $7.0 \mathrm{ml} / 1$ iter; the lower values occur in bottom waters during summer. Based on these measurements, the SHL report suggested that oxidation of the organic matter of the wastes and bacteriological activity in the sludge beds periodically depletes the overlying water of its oxygen to levels too low for the support of 1 ife. Such low values occur for only limited periods of time not only in the dumping grounds but also in other parts of the Bight.

The organic matter content of the Bight is extremely high, reaching values of 4.4 to $81.0 \mathrm{mg} / 1$ according to SHL. - This organic material precipitates eventually to the bottom and exerts a continuous oxygen demand on the overlying waters. According to Ketchum (1970), reduction in the oxygen content of bottom waters of the Bight dumping grounds has occurred recently. Horne et al, (1971) indicate that there is no evidence that oxygen depletion observed in the Bight extends into the water column for more than 5 meters off the bottom. It has also been suggested that periodic drops in DO in the Bight result from intrusions of offshore, oxygen-depleted waters which are generated below the we11-developed summer thermocline.

In contrast, Corwin and Ketchum (1956) point out that the Hudson River is a source of oxygen-depleted water, and that the oxygen content in the surface waters of the Outer Harbor can be as 1 ow as 1.8 to $2.0 \mathrm{ppm}$. River water, intruding into the Bight may be a more direct threat to the marine environment than the dumping.

To assess adequately the Do concentrations in the Bight, measurements should be taken diurnally and seasonally, something that has not 
been done by the investigations completed to date. (SAC, 1972) A biochemical oxygen demand (BOD) study should be conducted to determine the oxygen demand of sewage deposits and their state of digestion.

On the basis of present data, it can be concluded that the DO concentration of the waters above the dumping grounds may be reduced by the BOD of the wastes, but this effect has not been sufficiently substan tiated or quantified. The DO concentration of these waters for short periods reaches values below water quality standards.

On the basis of these conclusions, it is recommended that the natural seasonal variation of oxygen concentration in the dumping grounds and elsewhere in the Bight be determined.

g. Nutrients. Nutrients, such as phosphorus and nitrogen, are important properties of water and sediment quality of marine environments. Numerically defined criteria for nutrients, however, have not been established.

The National Technical Advisory Committee (NTAC) of EPA in its Water Quality Criteria report (EPA, 1972) comments that the naturally occurring ratios and amounts of nitrogen (particularly $\mathrm{NO}_{3}$ and $\mathrm{NH}_{4}$ ) to total phosphorus should not be radically changed by artificial means, but does not define permissible levels of phosphates or nitrates. Similarly, New York and New Jersey do not have specific criteria limiting the amount of phosphates and nitrates in interstate waters. (EPA, 1972)

Phosphorus and nitrogen, occurring as phosphate, ammonia, nitrite, and nitrate are important nonconservative constituents of seawater, necessary bio-stimulants for algal growth, and therefore, intimately involved in the life processes of the sea. Nutrient-rich waters can significantly alter aquatic systems, create algal blooms, and eutrophication in estuaries and restricted bodies of water, but not in open marine environments like the Bight.

The natural concentrations of phosphates and nitrogen compounds in seawater are relatively low, and areas in the ocean which are rich in such nutrients, are generally biologically productive. Phosphates are important in the process of photosynthesis which utilizes them while releasing oxygen. Phosphorus in the sea occurs in the form of dissolved phosphate $\left(\mathrm{HPO}_{4}{ }^{3-}\right)$, or in the more predominating form, orthophosphate $\left(\mathrm{PO}_{4}{ }^{3-}\right)$. The natural flux of phosphorus through marine ecosystems is subject to complex processes involving many cycles and equilibria. According to Ryther and Dunstan (1971), there is no evidence that phosphorous is ever the limiting nutrient in marine estuarine systems. Its potential limiting character has been demonstrated only for freshwater systems. The study of phosphorus flux (or any essential element) through a marine ecosystem, however, is a useful index in assessing metabolic processes of that system. (Mann, 1971)

Nitrogen, in the form of nitrate, is also an important nutrient, and 
is essential for photosynthesis. In the sea, nitrogen is introduced from decomposition of biomaterial, primarily as ammonia, $\mathrm{NH}_{3}$, which is then oxidized to nitrite, $\left(\mathrm{NO}_{2}{ }^{-}\right)$, and finally to nitrate, $\left(\mathrm{NO}_{3}{ }^{-}\right)$. Under natural conditions, nitrogen compounds are exhausted first from the marine environment, thus making nitrogen a limiting factor.

Waste materials dumped in the Bight contribute significant amounts of nutrients. Decomposition of organic matter dumped in the area reduces complex protein molecules to nitrates, phosphates, carbon dioxide, and water. Nutrients exist in both the sediments and the overlying waters of the Bight dumping grounds in above-natural concentrations. Available nutrients are dissolved in the water, absorbed on the pelagic particulate system, or are included in the sediments. The sediments of the dumping grounds collected for the referenced studies were not analyzed for nutrient content, but it is expected that these are in a state of dynamic equilibrium with those in the water phase, and could contribute to the available nutrient supply if other environmental variables were changed. Nutrient release from the sediments could depend on such factors as circulation of overlying waters, oxygen supply, and on the presence of rooted algae such as mycrophytes which are able to use these nutrients directly from the sediment phase.

Waters of the dumping grounds were analyzed for phosphorus by SHL. They found concentrations up to 5.64 microgram-atom per 1iter ( $\mu g-a t / 1)$. Other nutrient values reported by SHL for the sewage sludge dump were often unusually high; the reported $\mathrm{N}: \mathrm{P}$ ratio was unusually $1 \mathrm{ow}$. SHL use of phosphorus as a tracer of water mass movement was questioned by the SAC. The data presented by SHL appeared insufficent in time and space to allow proper tracing (SAC, 1972). According to the SAC, it would be necessary to analyze samples of water before, during, and after dumping to estimate the dispersion of nutrients.

The high concentration of phosphorus observed in the area could be due to recent dumps. Concentration of more than $2 \mu \mathrm{g}$-at/1 orthophosphorus found in the surface waters of the Irsh Sea was considered extraordinary by Jones and Folkard (1971). Ketchum (1969) suggested an upper 1imit of $2.8 \mathrm{\mu g}-\mathrm{at} / 1$ for defining unpolluted coastal waters. The amount reported by SHL in the dumping grounds of the Bight is about twice the maximum value suggested by Ketchum for unpolluted waters. It has not been demonstrated that high concentrations of phosphate are particularly critical for open marine environments. Higher phosphate values which may be of concern, have been reported for closed estuarine areas of the N.Y. Bight. Ryther and Dunstan (1971) reported a value of $7.0 \mu \mathrm{g}-\mathrm{at} / 1$ inorganic phosphorus in Moriches Bay, Long Island, which was associated with pollution from nearby duck farms.

The effect of additional nutrients on water quality can be better assessed by considering its direct effect upon primary productivity, and (more specifically) on chlorophyll production. It is expected that enrichment of the waters of the Bight in nutrients such as phosphorus, resulting from dumping of sewage sludge, could have a beneficial effect 
in the area, and would enhance marine productivity.

In their investigation of the Firth of Clyde Estuary dumping grounds, Mackay, Halcrow and Thornton (1972) report an increase in the productivity of that particular area which was attributed to nutrients in the waste. Similarly, Yentsch (Ketchum, 1969) plotted the log of inorganic phosphorus against the $10 \mathrm{~g}$ of chlorophyll-a, and determined a linear correlation between the two. SHL, utilizing Yentsch's technique and its own data for the Bight, did not find a linear correlation. Other environmental factors therefore must affect the relationship between chlorophyl productivity and the phosphorus content in the waters in the disposal areas of the Bight. One factor, perhaps the most important for the area, is salinity. Turbidity may be another.

SHL reported that the bulk of primary productivity occurred in waters of river orinin with lower salinity. SHL also stated that nutrification of the wates of the dumping grounds did not result in an extensive increase in the primary productivity of the area. Barber and Krieger (1970), suggested that phytoplankton cel1 division is retarded in water samples obtained from the sewage sludge grounds. They have given no reason for the suggested retardation, and have not related it to nutrient concentrations.

h. Heavy Metals. Heavy metals which are often present in the sea and are toxic to man in varying degrees, include, mercury, silver, arsenic, chromium, cadmium, copper, lead, nickel, and zinc. The toxic effects of these metals may be persistent and cumulative over the long term. Minute quantities of certain heavy metals are known to be important in metabolic processes of man. Most heavy metals serve no known biological function in the marine environment, and can act synergistically with other chemical substances to increase toxicity.

Marine animals, especially shellfish, are known to concentrate these heavy metals in their tissues, and (if eaten) may be a toxic source to man. Because of their toxicity and cumulative toxic effect, large concentrations of heavy metals constitute perhaps the most dangerous chemical species in the marine environment.

Heavy-metal criteria and limits for water vary widely from State to State. Neither New York nor New Jersey have defined specific criteria. The NTAC of EPA in its report "Water Quality Criteria," cites the U.S. Public Health Service Drinking Water Standards (EPA, 1972). According to these standards, desirable criteria for water place heavy-metals concentrations near zero. These are for drinking water, and are completely unrealistic for coastal marine environments such as the New York Bight.

Heavy metals are associated with ocean dumping in other areas. A study of the sewage sludge dumping in the Thames River Estuary, in England, found high concentrations of heavy metals in the sediments. (Shelton, 1971) High values of heavy metals have been reported for the Firth of C1yde, Scotland (Makay, Halcrow and Thornton, 1972), and for the coastal waters of California (Hlavka, 1971). 
Sewer sludge and dredge spoils dumped in the New York Bight contain especially high concentrations. of lead, chromium, copper and other common industrial heavy metals. Table 8 (on page 60) compares concentrations of some heavy metals found in sludges to natural levels in sea water and to concentrations toxic to marine life.

In determining the reactivity of heavy metals, their uptake in the food chain, and their toxic potential, knowledge of the relative concentrations in the sediments is necessary, but not sufficient. Knowledge of the physical status of these metals following disposal is necessary. Do these metals exist in ionic form? Do they form organic ion complexes? Do they exist as relatively inert insoluble compounds in the bottom sediments? Are they included as colloidal suspensions in the water column? What are the mechanisms, or conditions, that may result in their transfer, deposition or reactivity? Technology has not provided answers to these questions.

Completed studies by the SUNY-SB and the SHL have helped determine the relative concentrations of heavy metals in the sediments of the Bight dumping grounds. Both studies found that sediments contained heavy metals in much greater concentrations than in other nonspoil areas. Higher heavy metal concentrations were found by SHL at stations north of both dumping sites and south, along the length of the Hudson Canyon, suggesting possible spreading of the wastes. Concentrations of certain heavy metals given in the SHL report (Tables 2-2, 5-10 and 5-17) show 1arge, tempora1, withinstation, variations, suggesting a patchy distribution of sediments and a heterogeneous distribution of heavy metals within the disposal areas. Neither the SHL nor the SUNY-SB reports account for within-station variations of heavy metals in their analysis (SAC, 1972), although the SUNY-SB report presents statistics on selected samples.

SHL study concluded that the observed buildup of heavy metals is closely associated with waste disposal in the area. This is not a fully supported conclusion. It cannot be denied that ocean dumping is primarily responsible for the high levels of heavy metals in the sediments of the dumping sites relative to other shelf sediments not covered by waste materials, but a buildup (in relative concentration) of heavy metals within the dumping grounds is not apparent from the SHL data. In fact the SUNY-SB study (Gross et a1, 1970) shows that a diminution rather than a buildup, of heavy metals such as chromium, lead, silver and copper in the sediments of the dumping grounds has occurred relative to the parent waste material (inner harbor sediments and sewage sludge). The mechanisms for the diminution are not demonstrated and it is possible that a transfer occurs by lateral loss due to sediment transport, mixing with shelf sediments, or flux to overlying water.

The possibility that heavy metals enter the marine food chain is important, since the apparent decrease of heavy metals from these deposits is unexplained. However, Gross, et al., (1971) concluded that because of the relatively low extraction efficiency with hot hydrochloric acid, it seems unlikely that the metals would leach from the waste deposits and enter the overlying water. This was disputed by the SAC review (SAC, 
1972) in that the fate of heavy metals in the waste deposits is not a question that can be answered with present knowledge. Similarly disputed was the SHL conclusion that heavy metals, such as copper, lead, chromium and mercury in the water, originate from the sewage sludge and dredge spoil dumping sites. The SHL data on the concentrations of certain heavy metals ( $\mathrm{Zn}, \mathrm{B}, \mathrm{Fe}, \mathrm{Mo}, \mathrm{Mn}, \mathrm{Cu}, \mathrm{Sr}, \mathrm{Al}, \mathrm{Ba}$ ) in water samples collected at only six stations (Table 5-11 of the SHL report) has been questioned by the SAC since a cause-effect relationship was not clearly established. The SAC felt that the techniques used by both studies did not clearly demonstrate the mobility or lack of mobility of heavy metals from the waste deposits of the dumping grounds. Determining the reactivity of heavy metals based on acid extractions was not possible because of the variability of extraction with different concentrations of acid.

Neither study provided for the vertical distribution of heavy metals throughout the waste deposits. The SAC maintained that analysis of the heavy-metal content of interstitial water at selected depth in cores would aid in determining whether heavy metals are leaching from the waste deposits.

Differences in the methods and analyses in the SUNY-SB and SHL studies make comparison of the chemical results difficult. No significance can be attached to differences in heavy-metal contents of sediments determined by SUNY-SB and SHL because uniform extraction procedures were not used. (SAC, 1972)

The method of sample collection using grab samples could also produce variations in the results of both studies. The grab sampler would have the tendency to disturb the sediment and not necessarily reflect in situ distribution of constituents.

In conclusion, the results obtained to date indicate that high concentrations of heavy metals are found in the sediments of the dumping grounds. The fate of these heavy metals, their effect on water quality and their toxic potential have not been determined.

i. Organic Fraction. Quantitative numerical limits have not yet been defined by EPA in its water quality standards for oil, petrochemicals, or synthetic organic compounds. Existing restrictions are descriptive, and state that no oil or petrochemicals should be added to receiving waters in such quantities as to: "produce a visible film on the surface; impart an oily odor to the water and oily taste to the fish and edible invertebrates; coat the banks or bottom of the water course, or taint any of the associated biota; and finally, become effective toxicants." New York and New Jersey have similar descriptive restrictions on oil and petrochemicals. (EPA, 1972) None appear to apply to the offshore marine environment.

The sediments associated with ocean dumping areas are usually characterized by high organic contents. The organic materials found in such areas may be natural, synthetic, or related to petroleum based 
hydrocarbons. MacKay, Halcrow and Thorton (1972) in their study of the Clyde Estuary sludge disposal area in England reported the highest values of organic carbon near the center of the dump. Shelton (1971) reported a buildup of organic matter in the Thames disposal area, which he suggested may be the result of the normal traction load of organic matter usually found in the River Thames. Bottom sediments near the dumping grounds of the N.Y. Bight are also characterized by a high organic content in excess of normal values observed in nonspoil areas. (Figs. 33 through 35). Apparently this high organic content of the sediments has resulted from the dumping of wastes. Sewage sludge accounts for most of the organic material; dredge spoils are composed primarily of inert substances. However, toxic organic substances in polluted dredge spoils (even in low concentrations) may constitute a greater environmental concern than those of the sewage sludges.

Organics in the sediments of the Bight dumping grounds may include natural organic materials, synthetic organic compounds, and petrochemicals. The relative contents or effects of each type have not yet been established by the studies completed.

The natural organic materials in the sediments of the dumping grounds result from natural decomposition of marine plants and animals, or from organic constituents contributed by dredge spoils and sewage sludges. These materials are not harmful to the marine environment, and sometimes their addition may be beneficial. The major problem of the organic fraction is their biochemical oxygen demand. Large concentrations in the sediments may consume the dissolved oxygen and result in anaerobic conditions at the sediment-water interface. Indirectly, reducing conditions caused by these wastes, could affect the chemistry of other compounds. The effects of reduction of dissolved oxygen were discussed on page 117 .

Another class of organic materials in the sediments of the dumping grounds may be synthetic organic chemical compounds. Their content in the sediments has not yet been adequately determined by any of the studies completed. These compounds may be accumulating in the sediments of Harbor, and thus be included in the dredge spoils dumped in the Bight. To a lesser extent, these compounds may also be in the sewage sludges. The origin of these compounds may be point sources such as industrial discharges, or sources such as atmospheric precipitants or runoff from agricultural areas. Examples of these types of compounds are pesticides such as DDT, or polychlorinated biphenyls (PCBs), which have a cumulative toxic effect on marine life. Depending on the physicochemical characteristics of the marine environment, these synthetic organic materials may be found relatively undisturbed or may be broken down into other compounds. A pesticide such as DDT may be broken down by micro-organisms into DDE and $\mathrm{DDD}$, both of which are insoluble in water. These chemicals may be taken into the fatty tissue of certain marine organisms and be transmitted up the food chain. PCB's are toxic substances which, according to Gustafson (1970), present a real danger to marine life when accumulated in the sediments. 
The third class of organic compounds known to be present in the dredge spoils of the Bight are oil, grease and other petroleum-based hydrocarbon materials. These probably accumulate in the sediments of certain polluted sections of the Harbor, which occasionally are dredged. As discussed earlier, material dredged from the Harbor contains on the average 8-10 percent organics (Panuzio, 1965), and Hudson River sediments have 5.5 percent (McCrone, 1967). A large part of this organic material is suspected to consist of petrochemicals. The presence of this class of compounds has been documented for other areas where dumping has taken place. Saila, et al, (1968) reported that dredge spoils disposed of in Long Island Sound were contaminated with hexane extractable petrochemicals. Petrochemicals in the water are known to adversely affect microfauna and flora and macro-organisms, and to interfere with the chemical stimuli which are essential for spawning or predator-prey relationships of marine animals.

Both the SUNY-SB and the SHL studies have shown the presence of high concentrations of organic materials in the sediments of the dumping grounds and surrounding areas which correlates well with the distribution pattern of coliform bacteria and heavy metals. The SHL report states that the slowly settling sludge generally moves northward, resulting in the deposition of organic material for some distance to the north and northeast of the dumping grounds. A field of high organic material concentration in the sediments has been reported by SHL to the east of the dumping grounds but with no continuum. The organic material in this area is of mysterious origin, and cannot be related with certainty with the dumping activities.

Observed changes in the distribution of organic matter in the sediments suggest (besides movement of suspended waste by water currents) the possibility of short dumping.

The method of utilizing percent total carbon composition to determine the distribution of the waste and the potential of contamination is erroneous. Loss on ignition is a more reliable method, but has its own limitations. Both percent total carbon composition, and loss-onignition methods do not specifically identify the origin of the carbon, although the SUNY-SB study shows a direct correlation between the two for sewage sludges. Does this organic material originate from carbohydrates, sugars or proteins of the sewage sludges? How much of this material represents petrochemicals or synthetic organic compounds? How much is the result of naturally occuring organic compounds or the result of increased biological productivity? These questions have not been answered. Incinerator barges have been dumping ashes in the Bight for many years. Ash residues contain relatively inert carbon compounds, and these substances would also add to the percent total carbon composition of the sediments, making the SHL and SUNY-SB results questionable.

Finally, the quantity and exact composition of organic materials in the sediments may be indicative of potentially hazardous substances such as petrochemicals or synthetic organic compounds, and may help differentiate 
harmful from harmless or inert organic compounds. The data obtained by SHL on the petrochemicals and pesticide contents in the waste sediments are statistically insufficient, and can only be regarded as preliminary observations from which conclusive evidence cannot be drawn (SAC, 1972). Future research should focus on identifying organic groups and determining the toxicity, residence time, degradation and uptake of some of their hazardous components.

j. Bacteria. Data on bacteria distribution were presented in the sections dealing with the biological characteristics of the Bight and effects of dumping on ecology. Additional discussion of this important environmental factor is given here as it relates to criteria for water and sediment quality.

Presently EPA gives permissible coliform levels of 10,000 per $100 \mathrm{~m} 1$ and fecal coliform levels of 2,000 per $100 \mathrm{ml}$. Desirable criteria levels are given as 100 per $100 \mathrm{ml}$ for coliform groups and 20 per $100 \mathrm{ml}$ for fecal coliform groups (EPA, 1972). These microbiological limits are monthly arithmetic averages based on many samples. EPA, in its Water Quality Criteria report, states that "total coliform limits may be relaxed if fecal coliform concentration does not exceed the specified limit." The New York bacteria criteria are established by the State's public health agency, and vary depending on the use of the water body. No reference could be found in the criteria for offshore waters. The State of New Jersey designates the ocean area beyond 1,500 feet from the coast as a secondary contact recreation area, and its permissible fecal coliforms geometric mean is given as 200 per $100 \mathrm{ml}$ (EPA, 1972).

Most bacteria in nature are essential to the marine environment, but pathogenic bacteria are potentially hazardous to the health of marine organisms. Bacteria, as the foundation of the food chain, are essential to life processes. Bacteria may act as anti-pollutant agents in breaking down and degrading organic matter. In sewage treatment plants certain bacteria are cultured for the purpose of breaking down wastes.

Bacteria can be grouped into two major classes; aerobic bacteria that need free oxygen and anaerobic bacteria that thrive in its absence. Pollutants such as sewage sludge or dredge spoils dumped into the marine environment can promote the abundance of Saprophytes. The dumping of nutrients, such as those contained in sewage sludge, and other oxygendemanding wastes can create favorable conditions for the growth of anaerobic bacteria resulting in the death of aerobic organisms. This is true for estuaries and other closed bodies of water where oxygen cannot be adequately replenished by circulation; it is not likely in an open marine environment such as the Bight.

No data could be found in the literature for Saprophytes or other aerobic or anaerobic bacteria in the Bight. The emphasis of all investigations was on total coliform or fecal coliform bacteria, because of the associated health hazards. As mentioned earlier, fecal coliform bacteria are used as indicators of the possible presence of pathogens in 
the water. Inadequately treated and disinfected sewage could contaminate receiving waters with bacteria such as Salmonella, Shigella, Escherichia coli, Leptospira, and Mycobacterium. Enteric viruses such as polio and hepatitis could also be introduced (EPA, 1972). On the basis of studies completed, there is no evidence indicating that these pathogens and viruses are introduced into the Bight or that their density of occurrence constitutes a health hazard. In fact, none of the studies completed to date has identified pathogenic bacteria. However, cases of infectious hepatitis in shellfish from Raritan Bay have caused the closing of this area for shellfishing.

The distribution of bacteria, within each disposal area, as determined by the SHL, appears to be high as a result of the dumping activities. The pattern of distribution appears to conform with the mixing and dispersion processes in the area. High numbers of fecal coliforms suggest the introduction of pathogenic organisms into the Bight. The relative concentrations or types of these pathogens have not been determined and sampling has been inadequate. In view of the possible human hazard that could result from eating seafood that may carry pathogens, it is recommended that studies of pathogenic bacteria in the Bight be given a high priority.

\section{Effects of Ocean Dumping on Regional Ecology}

The biological effects of waste disposal in the Bight have been difficult to assess over a short time. The SHL study (1972), is the only large-scale biological study of the Bight undertaken to date. According to SHL, a circular area encompassing each of the waste disposal sites is devoid of benthic life, and peripheral areas are either severly impoverished or dominated by certain pollution-resistant species. Laboratory studies on the response of various animals to waste contaminated sediments, according to SHL, showed the development of several pathological anomalies.

Although the benthic life investigations involved much sampling, several important questions remain unanswered. Some SHL conclusions have been questioned. The conclusion that important quantitative changes in the fauna have resulted from dumping should be further investigated. Future research should try to determine whether these changes result from dumping or from natural processes, or from estuary and upland pollution. Other research should study why groundfish venture into this area, and why the stomachs of fish caught in the dumping area contain large quantities of benthic, epibenthic and swimming organisms, when these species are considered to be absent or diminished in the dumping grounds. Apparently these food resources are obtained within, or on the periphery of the dumping grounds. The fact that many of the marine organisms are feeding in the area of the dumping grounds is a matter of concern. The Bight is actively fished, and possible health hazards should not be discounted. The wastes dumped in the Bight are known to contain toxic substances and harmful bacteria. The long-term effects of these hazardous materials have not been assessed. On the basis of present 
knowledge, the short-term effects of waste disposal on different marine ecosystems are discussed in the following sections.

a. Effects of Ocean Dumping on Benthic Organisms. Some studies on the effects of dumping or related activities in other coastal areas, have not found extensive damage to the marine environment (U.S. Fish and Wild1ife Service, 1970; Kaiser Engineers Consortium, 1969; Allan Hancock Foundation 1965; Brehmer, et al, 1967; Harrison, 1967). The results of these studies are summarized in section II of this report. In all studies, the most marked effects and changes have been observed in benthic communities, because these are the most sensitive to environmental stresses due to their specialized adaptations and limited mobility.

Studies completed in the Bight dumping grounds have found impoverished benthic populations. SHL found that both the benthic meiofaunal and macrofaunal organisms have been affected by the disposal of sewage and dredge spoils in the Bight. The presence of these wastes have significant$1 y$ reduced the diversity of benthic communities, and this reduction indicates environmental stress caused by dumping.

In the absence of adequate spatial or temporal base-line information, this conclusion is not fully supported. Even under natural conditions, species diversity varies greatly with natural stresses. A lowered species diversity index may not necessarily be a negative factor. Whether species diversity or reduction in the abundance of certain species should be used as the sole criterion of environmental stress, remains to be seen. Species diversity nonetheless is useful as an index to be used in conjunction with other indices of pollution.

A study of the effects of dredging and spoil disposal in areas of San Francisco and San Pablo Bays indicated a significant reduction of numbers and species composition of benthic organisms and demersal fish. (U.S. Fish and Wildlife Service, 1970). A quantitative correlation of species diversity depression with waste water toxicity has been indicated by previous studies (Kaiser Engineers Consortium, 1969; Allan Hancock Foundation, 1965). These studies found a linear relationship may be an oversimplification, since species diversity may result from physical and chemical variables, some of which may have nothing to do with manmade pollution. A study of Rappahannock Shoal spoil disposal area (Brehmer et al, 1967) for example, indicated a greater species diversity and number of organisms in the spoil areas than in the natural ooze-covered substrate in the deeper parts of Chesapeake Bay.

Wilhm and Dorris (1966, 1968); Wilhm (1967) and Gibson (1966), have discussed the use of species diversity as an indicator of stress due to natural physical factors and pollution. The use of chemical properties as indices of environmental stress may be misleading, since chemical measurements indicate water quality at the time of sampling and not past contamination or conditions prevailing over long periods. 
Butcher (1955) states that in the presence of numerous and complex pollutants, environmental stress can be determined best from prevailing biological conditions rather than from chemical measurements. To a degree this is a correct approach, but maybe not the most reliable. Observation and analysis of species diversity of benthic populations, if supported by sufficient base-line data, can undoubtedly help to assess environmental severity. Such base-line data does not exist for the N.Y. Bight. Use of chemical indices as a sole determining factor for water quality may not be sufficient or definitive, biological factors also should be considered. Biological methodology should focus on selected "key" species of fishes or invertebrates that could indicate environmental stress, rather than attempt to sample one entire group excluding all others.

Disposal of wastes in the Bight presents a stress to the benthic communities of the area, but without base-line information, factors injuring benthic organisms are not completely understood. Reduction of species diversity may be the result of synergistic chemical-physical effects; some of these may be associated with dumping. No separation of individual stress factors, can be made because of the limited data. Furthermore, the N.Y. Bight dumping grounds have certain estuarine characteristics, and do not represent an open marine environment. Located at the mouth of a major estuary, this area experiences large variations of temperature, salinity and of other chemical-physical variables.

Reducing sediments cause a reduction of the dissolved oxygen near the sediment-water interface. Reduction of oxygen and physical burial by continuous dumping, probably cause the most immediate adverse effect on benthic communities. Oxygen reduction, although an important factor, occurs only for brief periods in the summer, and it appears to be a widespread phenomenon in the Bight.

Burial of benthic organisms depends on the quantity of waste, on the rate of disposal, on the settling rate of the waste, and on the areal extent of dumping and settling. A study of a dredge spoil disposal site in Rhode Island Sound (Saila, et al, 1971) concluded that most mollusk species could reach the sediment surface after shallow burial; less mobile forms were buried; fish and lobsters could withstand high concentrations of suspended sediment for short periods, and lobstering on the perimeter of the dump was good; quahogs were killed by burial near the dump center, but not on the perimeter; and amphipods were found throughout in great densities. Similarly in a study of a shallow-water dredge spoil disposal site in upper Chesapeake Bay, Cronin et al (1967, 1970) observed no significant losses of benthic organisms as a result of burial. Certain species began repopulation soon after deposition, and 1.5 years later were back to previous levels.

In a study of a disposal site in the lower Chesapeake Bay, Harrison (1967) concluded that disposal of spoil had only a transitory effect on benthic populations. It should be pointed out that the quantity of 
material dumped at these other sites is much less than the quantity dumped in the Bight. Destruction of benthic organisms, especially meiofaunal, by burial in the Bight is much greater at the dredge spoil site. Dredge spoils usually have greater bulk densities and settle to the bottom faster than sewage sludge or fine muds.

Finally, the toxic effects on benthic life of waste being dumped in the Bight will have to be more thoroughly investigated. Heavy-metal analyses of some benthic organisms (including bottom-dwelling fish) collected in the Bight dumps, showed increased concentrations in some speciments. The long-term effects of heavy metals on the health of benthic organisms have yet to be investigated.

(1) Effects on Meiofauna. The SHL study indicated that the meiofauna, especialiy the Foraminifera, are the most ubiquitous and abundant animals in the Bight, and are important in the assessment of the effects of ocean dumping. Of the 36 meiofaunal taxa identified by SHL from the Bight, 23 were 1iving Foraminifera. The data from 16 stations are given in the SHL report. Differences in the number of taxa between station 59 (in the sewage sludge disposal area) and station 39 (between the dredge spoil and the sewage sludge areas) are concluded to indicate impoverishment of the meiofauna. (Table 13). However, station 47, far from the dump sites, had fewer taxa than station59. Similarly, within-station difference of data were observed, and no replicate samples were obtained at stations with spatial heterogenity. Limited data and lack of replicate sampling led SAC to conclude that only qualitative reliability can be placed on the meiofaunal study (SAC, 1972).

Reconnaissance studies of the meiofauna in N.Y. Harbor and adjacent waters by Smith in the SUNY-SB report (Gross et al., 1971) differ with some results of the SHL. According to SUNY-SB, few living Foraminifera were found in New York Harbor, but samples taken in the Bight indicate an abundance and diversity typical of the open Shelf, with no apparent adverse effects from dumping. The results of both studies permit only qualitative evaluation of changes in abundance and diversity of the meiofauna. The low incidence of forams and ostracods in the Harbor suggests that higher concentrations of pollutants may destroy the meiofauna, and that meiofauna animals are not indefinitely insensitive to environmental deterioration. On the basis of present knowledge, the relationship cannot be quantified. Qualitatively, it can be concluded that waste disposal has had an adverse impact on the meiofaunal communities of the N.Y. Bight dumping grounds.

(2) Effects on Macrofauna. SHL found that an area about 2 miles in diameter encompassing each of the dumping sites is devoid of macrofaunal benthic life. Areas peripheral to the sludge dumping grounds were dominated by large numbers of Cerianthus, a burrowing type of sea anemone. None of these benthic species, however, is of direct economical importance to man.

Gammarid amphipods in particular are important; they are food for finfishes. The numbers of these species were also found by SHL to be diminished. Finfishes, however, have other sources of food besides 
gammarid amphipods.

The SHL conclusion stating that "The central portions of the disposal areas contain almost no normal macrofauna," cannot be supported. Examination of SHL data summarized in Tables 12, 14, and 15 does not support this conclusion. The number of species within presumed affected areas for example, shown in Table 12, varied from 23 (Station 82) to 38 (Station 70). (Fig. 39). Outside the disposal sites, the number of species varied from 23 (Station 42) to 56 (Station 38). Within the central part of the sludge dumping area, station 59 had 31 species and station 70 had 38 species.

The lack of statistical analyses of the abundance of amphipods for stations within and outside the dumping grounds, as summarized in Table 14 , precludes the possibility of interpretation of these data, or the conclusion that "normal" fauna is lacking in the disposal areas (SAC, 1972). Similarly, there are no quantitative data in the SHL report indicating that any station sampled is "devoid of life" at all times (SAC, 1972).

The SHL survey because of an inadequate sampling grid did not determine the distribution and abundance of the ocean quahog or other commercially valuable resources such as surf clam, lobster and rock clam. Because of the limited sampling and lack of statistical analyses the SAC review found the studies of macrofauna inconclusive.

According to the SHL report, adult crabs found on the disposal grounds were frequently diseased or near death. Since the disposal grounds are in the path of crabs and lobsters which frequently migrate from inshore to offshore waters, SHL concluded that waste disposal may result in mortality of these larger crustaceans. Mortality of these animals was attributed to the fouling and necrosis of their gill tissues which decreased the respiratory surface area, and to the low oxygen concentrations in the bottom water.

In an effort to simulate real life conditions, and determine histological changes, moribund crabs and lobsters collected from the dumping areas were used by SHL for controlled laboratory experiments using substrata of sediments similarly obtained from the dumping grounds. These animals developed ulcers and shell erosions. Other effects included fouling of the gills with granular material, a dark coating of the exoskeleton, and erosion of the chitinous covering of the filaments with subsequent necrosis of the living tissues. Eroded tissues of the animals appeared brittle; and on occasion surface layers appeared to be broken. It should be noted that these effects were observed for animals in the laboratory and not for animals under natural conditions.

b. Effects on Finfishes. SHL assessed the effects of sewage sludge on groundfish, and found certain bottom dwelling finfishes frequent the area of the sewage sludge dump in all seasons and feed on dumped waste. It concluded that, because of such feeding, a heavy-metal concentration has taken place in the tissues of some fish. 
From SHL data, it can be concluded that the density distribution of finfish within and outside the dumping grounds of the Bight, appears normal. Of the species taken, whiting, ling, winter flounder, yellowtail flounder, windowpane, and longhorn sculpin occurred most frequently. On occasion large numbers of such fish as Atlantic mackere1, porgy, and various herring were caught.

Seasonal variations in the population density of finfishes in the sewage sludge dump area follow seasonal fluctuations of dissolved oxygen concentrations (SHL, 1972). It has not been demonstrated that such oxygen variations occur only in the dumping grounds and not elsewhere in the Bight. Similarly, attempts to relate fishery landings in the State of New York with adverse effects of pollution from ocean dumping operations have produced ambiguous results. While catches of certain species have declined, catches of other species have increased. Seasonal and natural variations, fishing by foreign vesse1s, and absence of effective conservation measures, are some of the factors that make landing statistics for this type of study meaningless.

SHL concluded that the dumping threatens many species of coastal fish such as weakfish, bluefish, fluke and croakers, and anadromous fish such as stripped bass, sturgeon, and shad. It was also concluded that ocean fish, such as tuna, could be driven away from present fisheries, and that migrating fish may spread contamination and disease to adjacent areas. These conclusions have not been documented. The effects, of any ocean dumping on the health of coastal fish, have not been positively assessed, and the SHL conclusions, according to the SAC review, cannot be statistically verified. The limited sampling design, the lack of temporal and spatial replication of samples, and the selectivity of fishing gear used, do not support the contention that a "representative picture of the fish population" was determined for any station or that concentration of heavy metals has taken place in finfish.

A recent study of Philadelphia's sewage sludge disposal grounds by the Franklin Institute and the Philadelphia Water Department (Baxter et al., 1971) found the fish there to be unaffected and apparently in good hea1th. Fish speciments collected at the disposal site included winter flounder, mackeral, stargazer, long-horned sculpin, and spiny dogfish. The quantity of sludge disposed by Philadelphia is much less than the huge quantity dumped in the N.Y. Bight, and the practice dates back on $1 y$ to 1961 .

Fine solids in suspension may adversely affect the gill epithelium of fish (Klein 1962), and can also affect invertebrates, especially filter feeders. Laboratory bioassays by SHL using incinerator ash residues (up to 10 percent by weight) did not produce significant size or weight changes on benthic organisms, but concentrations above 5 percent by weight killed winter flounder. Concentrations of acid waste greater than $1: 600$ (acid to sea water), in 1 ab experiments, killed the white mullet (SHL 1969). As stated earlier the volume of acid waste disposed in the Bight is not great, and the rapid dilution and neutralization of the acid 
probably excludes extensive mortality of these species. The study by Refield (1961) of the acid dumping grounds confirmed that the effects of acid waste disposal on fish populations and benthic organisms were insignificant.

of the bottom-dwelling finfishes sampled by SHL in the Bight only a small number of flounder collected from the sewage dumping area had black ened gills. In laboratory experiments by SHL, two winter flounder were kept in aquaria, one containing a substrate of sludge and the other a substrate of clean sand. A blackening of the gills occurred in the fish held in the aquarium with the sludge substrate, but the significance of this coloration was not established.

Parasitic organisms were found by SHL in some species of flounder. Tapeworms were common in yellowtail flounder ranging in incidence from 7 to 32 percent. The incidence of tapeworms in the yellowtail flounder at stations outside the dumping grounds was about four times greater than in fish collected at the center of the sewage dump where tapeworm infestation had the lowest value ( 7 percent). No particular pattern is evident from this investigation linking ocean dumping to tapeworm incidence in flounder. No literature was found which describes normal levels of tapeworm infestation in the yellowtail flounder, but flounders generally have a rich parasite fauna. Polyanskii (1955) reported the incidence of the tapeworm Scolex polymorphus in the common dab (Limanda Limanda) from the Barents Sea to be 25 percent. The chief intermediate hosts for many of the parasites are amphipods which occur in low numbers in the sewage sludge beds and surrounding areas. This may account for the lower incidence of tapeworm infestation.

Incidence of diseases such as fin-rot in bottom-dwelling finfishes was linked by SHL to waste disposal and associated pathogenic bacteria. This conclusion, however, cannot be fully substantiated, because the study did not identify nor measure the prevalence of pathogenic bacteria in the Bight. Besides, other causes of fin-rot disease have been mentioned in the literature, including high concentrations of mercury. According to Jeffries (1968), fin-rot infection can be caused simply by restricting the movement of the fish. Fin-rot is often observed in finfishes living in unpolluted marine environments. The SHL studies of pathogenic anomalies produced in finfish by sewage sludge were similarly questioned by the SAC. The inadequacy of the experimental design and consequent lack of adequate controls precluded the possibility of statistical analysis of the SHL data. The SAC therefore suggested that further investigation will be required to establish definitely the incidence of fin-rot and the greater uptake of heavy metals by finfish exposed to the sewage sludge.

It would be hasty to conclude, on the basis of present knowledge, that ocean dumping has had adverse effects on fish populations of the Bight. Introduction of possible toxic substances, such as heavy metals and complex hydrocarbons, is certainly undesirable, but long-term effects of such materials on fish are still unknown. 
SAC recommended integrated field and laboratory studies to determine whether the potential threat of pathogens and toxins affecting fishes in the waste disposal areas can be verified.

c. Effects on Zooplankton. The effect of dumping on planktonic life should be known, because zooplankton plays an important role in the food chain, and serves as the link between the phytoplankton and the larger marine animals. Any major dismuption in zooplankton production will affect the fish and other larger animals that use zooplankton as a food source. Environmental changes are known to change the composition and seasonal distribution of certain local zooplanktonic organisms. Jeffries (1959) relates a large increase in the Pseudodiaptomus sp., population of Raritan Bay to the abatement of a sewage discharge. However, significantly important changes in zooplankton organisms were observed in the New York Bight dumping grounds. Unusually high or low values of zooplankton numbers in the Bight, according to the SHL report, may be the result of an occasional influx of estuarine brackish water or an effect of major water mass movements and not the result of local disposal activities. Abnormal values were observed in July, 1969 indicating increased zooplankton patchiness during the summer months.

SHL data have illustrated that the zooplankton species composition, density, and seasonal distribution in the Bight are similar to those of Block Island Sound, the waters off Delaware Bay, and other unpolluted coastal environments. It was impossible to find any short-term adverse effects on zooplankton populations resulting from the dumping of sewage sludge, dredge spoils, and acid wastes. The SAC review similarly found no evidence in the SHL data that indicates that ocean dumping in the Bight has had beneficial or detrimental effects on zooplankton populations.

Although larvae of different marine organisms were abundant in the zooplankton, juvenile and adult populations of benthic species, were depressed in the sewage sludge disposal area (SHL). On the basis of this observation, the SHL study suggested that larvae either avoid settling in this area or that mortality occurs after settling, but this, has not been confirmed.

Based on laboratory experiments with zooplankton, SHL concluded that the present practice of industrial acid waste dumping killed copepods in the immediate area of disposal. The quantity of acid dumped is about 220,000 cubic feet per day. The maximum volume of sea water affected has been calculated to be $900,000,000$ gallons $\left(3,400,000 \mathrm{~m}^{3}\right)$ per barge load of wastes. This volume would contain about 2 cubic meters (displacement volume) of zooplankton biomass. This quantity of zooplankton, if indeed affected by dumping, is insignificant relative to total zooplankton population of the Bight.

According to the SHL study, the killing of zooplankton is the result of the acid wastes, which consist of $8.5-10$ percent $\mathrm{H}_{2} \mathrm{SO}_{4}$ and $8-10$ percent $\mathrm{FeSO}_{4}$. In laboratory experiments, SHL assumed a rate of dilution of one part acid to 200 parts of sea water disregarding time and space. 
The SHL toxicity tests on copepod mortality, are inexact because they did not include the dilution effect of turbulence which occurs readily in the ocean, but is difficult to simulate in the laboratory. Redfield and Walford (1951) show, that the $\mathrm{pH}$ of water from the wake of an aciddumping barge was above 6.0 in all samples collected more than 3 minutes after passage of the vesse1; a pH of 7 was reached about 3.5 minutes after dumping, and that acid disposal was not an important factor in copepod mortality. They reported that the zooplankton exposed to samples of water from the wake of the disposal vessels were immobilized, but recovered in a few minutes, except for a sample taken at 145 yards behind the barge only 42 seconds after discharge. Even these zooplankton recovered when the wake water was diluted with an equal volume of noncontaminated sea water. The SHL data (Table 18) showed no copepod mortality in 2 minutes at $\mathrm{pH} 5.9-6.0$ and no mortality in 60 minutes at $\mathrm{pH}$ values of 6.1-6.5. The dilution of the acid waste in the Redfield and Walford work shows that the organisms are not exposed to the high concentrations used by SHL in its laboratory tests. The SHL data, therefore, do not support complete mortality, and no such mortality was detected in the Bight.

The vertical migration of copepods is controlled by light intensity (Herman, 1963; Sega1, 1970). Copepods are found in deeper waters during daylight and near the surface at night. On the basis of this, SHL concluded that the ferric hydroxide floc resulting from acid dumping, although not directly toxic to copepods, produces turbidity that changes light conditions and affects the vertical distribution pattern of copepods. While this conclusion may be true, changes in vertical distribution of copepods may not be an adverse effect, and increased turbidity may not inhibit the abundance of these organisms. Reduced light intensity due to overcast skies could have the same effect. The ferric hydroxide floc either settles out or is dispersed rapidly. Refield and Walford (1951) reported the maximum time they observed a recognizable turbidity stain to be 8 hours. The ferric hydroxide floc is not toxic to copepods. In the laboratory, copepods held in water containing up to 500 times the concentration of ferric hydroxide found in the Bight survived several days.under starvation conditions.

Similar laboratory experiments by SHL showed that copepods can live in sludge-contaminated water for over 24 hours under confined conditions. Death of some copepods in the experiments over extended periods of time probably resulted from a decrease in dissolved oxygen caused by the biochemical oxygen demand of the sludge.

An aerated control in future experiments of this type would show whether there were any effects from sludge other than its oxygen demand (SAC, 1972).

d. Effects of Ocean Dumping on Phytoplankton. No extensive phytoplankton studies in the dumping grounds of the New York Bight have been conducted. Inhibition in the growth of phytoplankton in 1 ab cultures of water from the sludge dump has been reported by Barber and Krieger (1970). 
Table 18. Copepod Mortality at Different Acid-Sea Water Dilutions.

\begin{tabular}{|c||c|c|c|c|c|c|}
\hline Dilution & Control & $1: 200$ & $1: 500$ & $1: 1,000$ & $1: 2,000$ & $1: 5,000$ \\
\hline $\mathrm{pH}$ & 7.7 to 7.9 & 2.0 & 2.5 to 2.8 & 2.9 to 3.1 & 5.9 to 6.0 & 6.1 to 6.5 \\
\hline \hline $\begin{array}{c}\text { Approximate Percent } \\
\text { Dead After: }\end{array}$ & & & & & & \\
2 min. & 0 & 100 & 90 & 70 & 0 & 0 \\
5 min. & 0 & & 99 & 95 & 50 & 0 \\
10 min. & 0 & & 100 & 99 & 50 & 0 \\
30 min. & 0 & & & 99 & 50 & 0 \\
60 min. & 0 & & & 99 & 50 & 0 \\
\hline
\end{tabular}


On the basis of limited data, SHL concluded that the cell growth and photosynthesis of phytoplankton collected near the bottom of the sewage sludge dump was inhibited. This inhibition in primary productivity can be attributed to reduction in light intensity due to turbulence induced by the dumping rather than to toxic properties, and is considered quantitatively insignificant. In surface waters, an enhancement of primary productivity would be expected due to the nutrification caused by the sewage sludge. Since no net reduction in zooplankton populations was observed, ocean dumping in the area has had little effect on phytoplankton.

e. Effects of Ocean Dumping on Bacterial Distribution. SHL concluded that existence of coliform bacteria in the sediments and in the waters of the New York Bight dumping grounds indicates the existence of pathogenic bacteria. This conclusion was not confirmed by identification of pathogens. Large populations of unidentified bacteria are found in the surface waters of the dredge spoil disposal areas (Atlas 1972). Mahoney (1972) relates the occurrence of coliform bacteria in the waters near Sandy Hook with three genera of bacteria which have been associated with pathogens resulting in fin-rot disease. The SHL study indicates that the nutrient-rich waters of the dumping grounds could enhance the presence of pathogens which could spread disease into uncontaminated and ecologically important areas. The marine environment is foreign and adverse to most bacteria found in sewage and sewage sludges.

The rapid reduction in the number of coliforms after dumping, is probably illustrative of a rapid bacteria die-off due to the disinfecting capacity of sea water. Not only is the mortality of bacteria high, but the rate of metabolism of the surviving bacteria is greatly reduced. Mortality of bacteria would be even greater if the disposed wastes were disassociated and dispersed.

In his study at the Hyperion outfall in Southern California, Hlavka (1971) suggested that survival of coliform bacteria associated with floating particulate matter may differ significantly from that generally expected. Based on this hypothesis and the observation of floating particulates in the Bight dumping areas, SHL concluded that there may be a significant accumulation of bacteria at the water-air interface and in the water column as the particulates sink. Determinations of percentage floatable materials in wastes and rates of bacterial survival following dumping may be necessary to qualify this conclusion. Systematic analyses of sediments and samples from the water column should be obtained in the dumping grounds, the Hudson Canyon, and adjacent areas of the Bight to determine positively the existence of pathogenic organisms and the extent of bacterial contamination. Millipore filter techniques should be used to concentrate bacteria that may escape count by standard test techniques.

f. Effects of Heavy Metals on Marine Organisms. Metals such as cadmium, chromium, cobalt, tin, titanium, germanium and bismuth are present in sea water in low concentrations, and are known to be 
concentrated by some marine organisms. Some of these elements may be important in the skeletal mineralogy of these organisms, others may be important for other biological reasons. Some marine animals may preferentially concentrate one element over another. The body fluids of many crustaceans, for example, contain copper as hemocyanin, a respiratory pigment. High concentrations of certain heavy metals in the marine environment may have a long-term adverse effect. The toxicity potential of heavy metals and the biochemical uptake mechanism of marine organisms depend on many physical and chemical factors which are not well understood.

Total concentrations of heavy metals in the sediments, in the water colum, and in organisms, are of little value in assessing the impact on marine life. The concentrations of heavy metals, such as lead, chromium, copper, antimony, zinc, silver, nickel, in the area of the dumping grounds exceed concentrations of these elements in other undisturbed regions of the Bight. The effects of these heavy metals on the marine populations of this area have been difficult to assess.

Demersal and bottom-dwelling finfishes sampled by SHL within and at the periphery of the sludge dumping grounds, come into direct or indirect contact with various waste pollutants including heavy metals.

The question is raised if any of the heavy metals contained in the sludge are absorbed by the fish. Preliminary results of SHL indicate that some fish collected in the area of the dumping grounds have high levels of heavy metals in their tissues. Levels of nickel, chromium, and lead in fish and other organisms examined exceed those listed by the Federal Water Pollution Control Administration (1968) as normal for marine animals. It has not been demonstrated that high levels of heavy metals adversly affect the health of fishes, although it is suspected. Pippy and Hare (1969) claimed that certain metals predispose fish to disease, but failed to show how.

Of several hundred (bony fish) analyzed for mercury by SHL, weakfish (Cynoscion regalis) with fin-rot disease had the greatest amount of mercury in their tissues. Compared with healthy weakfish collected off the Virginia coast, which had an average of $0.31 \mathrm{ppm}$ in liver tissue, diseased fish from the N.Y. Bight had an average of $0.62 \mathrm{ppm}$ mercury in muscle tissue and $0.54 \mathrm{ppm}$ in the liver. SHL data are insufficient to correlate incidence of fin-rot in some finfishes to the heavy metals of the waste disposal grounds. According to Jeffries (1968), the infection can be caused by restricting the movement of fish.

Other bioassays in the laboratory have produced conflicting results. Wilder (1952) reported that in aquaria lined with copper, zinc and lead, marine organisms died in 1,9 and 20 days respectively.

SHL bioassays with lobsters (Homarus americanus), held on sediments from the sewage sludge area for 2 days, showed that these animals developed necrotic areas on their gills and died. Chemical analyses of 
their tissues did not show a high concentration of heavy metals. Because of such ambiguities, it is recommended that an intensive study be undertaken to determine the mechanism of heavy-metal uptake by planktonic and larger marine organisms. This is an important consideration in assessing possible concentration of such heavy metals in the food chain. Specific analyses should be performed on certain tissues of marine animals to determine if preferential concentration of metals in such tissues occurs, and the significance of such concentrations.

g. Effects of Organic Materials on Marine Organisms. Both sewage sludge and dredge spoils contain large quantities of organic material. Sewer sludges are particularly rich in organic material, ranging from about 50 to about 80 percent of the dry weight. Most of these materials consist of soluble acids, sugars, proteins, fats and esters, which are not harmful to marine 1 ife, and may be beneficial. Dredge spoils, although containing lower concentrations of organic materials than sewage sludges, may contain such dangerous constituents as pesticides and petrochemicals. These materials are known to be absorbed by the lipid and fatty tissues of marine animals, particularly by benthic organisms such as oysters and clams, and to interfere with the lipid metabolism and the enzymatic breakdown of fats into glycerids and fatty acids.

None of the studies completed in the New York Bight treated this problem. A study of Penicillium, Nocardia, Micrococcus, Candida, and other microbial organisms would be useful. Such organisms are known to attack components of petrochemicals such as olefins and napthas, by generating certain enzymes. An attempt should also be made in the laboratory to identify chemically the harmful hydrocarbons, and to check on the efficiency of micro-organisms to degrade them. Data from such an investigation would be helpful in determining whether active biodegradation of the oil-polluted dredge spoils occurs.

\section{Sources of Coastal Pollution in the New York Bight}

No evidence shows that ocean waste disposal is the most serious source of pollution in the Bight. Of equal concern should be other sources of pollution, such as sewer outfalls, river discharges, 1 and runoff, vessel discharges and accidental spills on 1 and and sea.

Basic sources of coastal water pollution fall into two broad categories: easily identified point-of-origin sources such as municipal waste treatment discharges and industrial plants, and waste from diffuse or non-point sources such as silt or fertilizers washed into streams during heavy rains as a result of agricultural and urban runoff. Additional sources may be atmospheric precipitants, thermal discharges, and accidental oil spills.

It is difficult to assign responsibility to any class of pollutants or to single out and quantify their adverse environmental effects. In the Bight, the adverse effects of coastal pollution from sources other than ocean dumping have not been considered to date, even though coastal 
wastes directly affect the immediate coastal environment. Up to 1972 , at least 130 municipal waste outfal1s discharged directly into the waters of the New York Bight (Table 19). The total flow was 1,843 million gallons per day. Of this flow, 16 percent received no treatment, 27 percent received primary treatment, and only 57 percent received more than primary treatment.

It was estimated that the yearly biochemical oxygen demand resulting from municipal discharges of sewage directly into New York Harbor exceeded 200,000 tons, which is probably greater than the oxygen demand resulting from sewage sludge dumping at the ocean dumping grounds.

Up to 1972, millions of gallons of poorly treated municipal wastes from 25 sewer plants were discharged along a 70-mile stretch from Sandy Hook to Beach Haven. These discharges have continued in New Jersey for more than 40 years in such municipalities as Asbury Park, Avon, Bay Head, Beach Haven, Belmar, Bradley Beach, Deal, Lavallette, Long Beach, Long Branch, Manasquan, Neptune City, Neptune Township, Ocean Grove, Point Pleasant Beach, Sea Bright, Sea Girt, Seaside Heights, Seaside Park, Ship Bottom, Spring Lake, Spring Lake Heights and Surf City. According to the New Jersey Department of Environmental Protection, which provided the New Jersey newspaper "Star-Ledger" (3 October 1971) with this 1isting, the daily capacity flows of waste treatment plants in these municipalities total nearly 33 million gallons.

Other sources of wastes and pollutants that may reach New York Harbor are municipalities and industrial facilities up the Hudson River. It was estimated by Dole and Stabler (1909) that the "normal" sediment load of the Hudson River was about 400,000 tons per yr. around 1900 . 1960 estimates by Panuzio (1965) gave the sediment load at 830,000 tons per yr. According to Gross (1970), between 1964 and 1968, about 700,000 tons per $y r$. of wastes were dumped into the river, and may have reached the Harbor. They were subsequently dredged up and barged to the ocean dumping grounds of the Bight.

Although it is assumed that 1 ittle suspended sediment in the outflows of the Hudson and Raritan Rivers may find its way to the offshore environment of the New York Bight due to the configuration of the Upper and Lower Bays and other physical barriers, this may not be true under certain heavy rainfall and storm conditions. Under such conditions, a great load of suspended sediments may reach the entrance of the harbor and be deposited offshore in the Bight.

Considering circulation and natural drainage patterns, such deposition probably occurs in the vicinity of the ocean dumping grounds and in the the vicinity of the now-buried upper head of the Hudson Channe1. A1though quantities of sediments resulting from such deposition cannot be calculated with accuracy, estimates of sediment discharges by some U.S. Atlantic Coast Rivers and other major rivers of the World, are given in the literature. Tables 20 and 21 list such estimates. It is possible, that because of natural sediment deposition and outflow of waters of 
Table 19. Sewage Discharges in the New York-New Jersey Region of the Bight

\begin{tabular}{lcc}
\hline \multicolumn{1}{c}{ Receiving Water } & Number & Total Flow* \\
\hline New York-New Jersey Metropolitan Area $\dagger$ & 57 & $1,682.0$ \\
Intracoastal Waters of Nassau County $\ddagger$ & 8 & 76.0 \\
Atlantic Ocean (New Jersey) & 31 & 39.0 \\
Intracoastal Waters of New Jersey Coastal Area $\S$ & 34 & 46.0 \\
\hline Total & 130 & $1,843.0$ \\
\hline
\end{tabular}

Ad Hoc Committee, 1970

* Million gallons per day

$\dagger$ Includes the municipal wastewater discharges from New York and New Jersey to: the Hudson River from the New Jersey-New York State line; the Upper and Lower Bays of New York Harbor; the Raritan Bay; the Arthur Kill; the Kill Van Kull; the East River and Jamaica Bay.

$\ddagger$ Includes the municipal wastewater discharges from Nassau County, New York to the intracoastal waters along the southern Long Island shore.

$\S$ Includes the municipal wastewater discharges from Monmouth, Ocean, Atlantic, and Cape May Counties to the intracoastal waters along the New Jersey eastern shore. 
Table 20. Annual Suspended Sediment Discharge of Atlantic Coast Rivers

\begin{tabular}{|c|c|c|}
\hline $\begin{array}{c}\text { North Atlantic Region } \\
\text { (Rivers) }\end{array}$ & $10^{6}$ Tons per Year & Tons per Year per $\mathrm{km}^{2}$ of Drainage Basin \\
\hline Connecticut & 0.89 & 3.1 \\
\hline Hudson & 0.40 & 12.0 \\
\hline Raritan & 0.071 & 29.0 \\
\hline Delaware & 0.72 & 21.0 \\
\hline Susquehanna & 0.96 & 14.0 \\
\hline Potomac & 1.4 & 37.0 \\
\hline James & 1.0 & 36.0 \\
\hline Region & 6.1 & \\
\hline \multicolumn{3}{|l|}{$\begin{array}{c}\text { South Atlantic Region } \\
\text { Rivers }\end{array}$} \\
\hline Roanoke & 2.5 & 99.0 \\
\hline Pee Dee & 1.6 & 59.0 \\
\hline Santee & 3.4 & 90.0 \\
\hline Savannah & 2.6 & 90.0 \\
\hline Ogeeche & 1.2 & 87.0 \\
\hline Altamaha & 3.0 & 83.0 \\
\hline Region & 21.8 & \\
\hline
\end{tabular}

from Gross, (1969) after Dole and Stabler, 1909

Table 21. Suspended Solids Discharged by Major Rivers

\begin{tabular}{|l|r|c|}
\hline \multicolumn{1}{|c|}{ (Rivers) } & $10^{6}$ Tons per Year & Tons per Year per $\mathrm{km}^{2}$ of Drainage Basin \\
\hline Niger & 5.0 & 4.6 \\
Amazon & 400.0 & 65.0 \\
Congo & 71.0 & 18.0 \\
Mississippi & 344.0 & 107.0 \\
Colorado & 149.0 & 418.0 \\
Rio Grande & 9.4 & 136.0 \\
Rhine & 0.5 & 3.0 \\
Yellow (Hwang Ho) & $2,083.0$ & $2,910.0$ \\
Ganges & $1,600.0$ & $1,540.0$ \\
Bramaputra & 800.0 & $1,430.0$ \\
Mekong & 187.0 & 479.0 \\
\hline
\end{tabular}


lower salinity in addition to waste disposed, the area never supported large benthic populations. This however, cannot be ascertained since base-line data on benthic populations before dumping is not available.

\section{Remote Sensing and Surveillance System for Ocean Dumping Operations}

Recent environmental legislation and concern over the environmental impact of marine waste disposal hastened the improvement and regulation of ocean dumping operations in the Bight. Accurate monitoring and surveillance of dumping is essential for effective discharge of this regulatory responsibility. It is important that the location and status of each dumping activity is known, and that dumping is restricted to the specified area.

Presently, due to the large volume of waste disposal in the Bight, and because the number of patroling vessels is limited, not all operations are supervised, and ocean dumping is believed to be occurring occasionally in localities other than the prescribed dump areas. The extent and type of such violations, termed "short dumps," is not exactly known. CERC contracted through the U.S. Army Corps of Engineers N.Y. District with Sperry Rand Co. to study, consider, and evaluate different combinations of navigational, dump detection, and recording subsystems, to create a reliable remote monitoring system. The work by Sperry was completed in 1971; the report is referenced in Literature Cited. Because of the report's specialized technical nature, no analysis is presented here and the interested reader is referred to this original report. Only a summary of the Sperry findings are given.

Specifically, Sperry Rand Co. considered and evaluated different combinations of navigational, dump detection, and recording subsystems. Navigational subsystems such as differential omega, loran C., loran A, shore-based radar with onboard radar beacons, and shore-based radio direction finders with onboard transmitters, were coupled with dumpdetection devices, such as draft-and events-sensors, and recording apparatus, such as onboard digital printers and shore-based recording equipment.

Careful evaluation of candidate systems and of the Corps' requirements by Sperry, indicated that the preferred system for monitoring ocean dumping operations should utilize loran A for position fixing, an electronically activated dump-detection subsystem, and an onboard digital printer subsystem. For self-propelled dumping vessels, the required system would be installed in one single "black box." This basic system is abbreviated as "LEPS" (for Loran-Events-Loran-Printer-System). When the dump sensing occurs on a towed barge or scow, the equipment on the towed vessel would be called "SIDS" (for Scow, Indicating Draft System).

Attractive features of the Sperry recommended System, are its containment in a single tamper-proof "black box," its portability, ease of installation and maintenance, high reliability, high legal effectivity, and simplicity of operation. 
In the absence of acceptable alternate methods of waste disposal, alternate disposal sites should be selected in areas where dumping can be controlled and potential environmental hazards can be reduced.

Stopping dumping at the present grounds and starting dumping at another location in the Bight, cannot be presently justified. Before selecting an alternate dumping site; a comprehensive research program should be undertaken which should include, physical, chemical, biological, and geological studies of alternate dumping grounds. These preliminary investigations should establish basic reference figures of biomass distribution before dumping, should furnish a detailed environmental description of the proposed grounds, and should provide guidelines for assessing the impact of dumping on the area.

Disposal of wastes at alternate sites should only begin after careful consideration of the type of waste, the rates of disposal, and the capacity of the area to absorb the waste and restore itself. A strict monitoring program should be required to ensure that wastes are dumped at the prescribed location and in the prescribed manner.

Selection of alternate dumping grounds in the New York Bight should be decided only after consultation with other Federal and State agencies and after thorough evaluation of many ecological, economic, political, geographic, and international considerations.

\section{Alternatives to Ocean Dumping}

The Council on Environmental Quality, in its 1970 report to the President, recommended that ocean dumping of materials harmful to the marine environment or man should be stopped, that disposal of sewage sludge and polluted dredge spoils should be phased out as soon as possible, and that consideration should be given to alternate procedures of waste disposal. (Council for Environmental Quality, 1970).

Alternative methods of waste disposal should be developed and evaluated. Research should be conducted on the recycling of wastes, and the technological development of processing facilities for the separation of toxic materials from municipal wastes. Analysis of the complex social, institutional, and economic aspects of waste management, wil1 be necessary.

To phase out the practice of ocean dumping and replace it with an untried alternate of questionable benefit and of increased expenditure does not appear logical. The ecological burden of alternate methods of waste disposal to other resources should be examined carefully. Air pollution and ground water contamination should be considered as an integral part of the effects of alternate methods on a larger environmental ecosystem. 
Because of the economic and technical limitations presently imposed by alternate waste disposal methods, and though ocean dumping is considered undesirable, it appears that this practice may persist until the transition to other alternatives can be effectively implemented.

A detailed discussion of alternatives to ocean dumping is not within the scope of this report. Such methods of waste disposal have been described in the literature. These include farming to inland disposal areas, creation of artificial islands, land filling with diking, land reclamation, incineration, containerization and sea disposal, treatment and 1 and disposal, deep well injection, recycling, and treatment and disposal in deeper waters. 
Much data have been gathered primarily on the physical, chemical, and biological characteristics of the waters and sediments of the New York Bight, as related to disposal of waste materials such as sewage sludge, dredge spoils and acid-iron wastes. The studies summarized in this report were supported by the Corps of Engineers under contracts with the Smithsonian Institution, the Sandy Hook Marine Laboratory of the National Marine Fisheries Service, the State University of New York at Stony Brook, the Woods Hole Oceanographic Institution, and the Sperry Rand Corporation.

The studies completed to date, include hydrographic, geological, chemical, biological investigations, and a feasibility study for a remotely controlled sensing system that could assist regulating agencies in detecting the location and dump status of waste disposal vessels operating in the New York Bight. Because of the specialized technical nature of this latter study, only the major findings and conclusions of the environmental studies on the effects of waste disposal are summarized below:

Dispersion and Movement of Waste - The dispersion and movement of waste materials after dumping were correlated with general circulation patterns of the Bight deduced from surface and bottom drifter studies. These circulation data indicate a strong flow at the bottom along the axis of the Hudson - Ambrose Channel into the mouth of the Hudson Estuary. Under tidal circulation the ebb in the Lower New York Bay is generally stronger than the flood and there is a net transport of water outward from the Hudson Estuary. The data also indicates that there is a general clockwise circulation in the Bight. Surface flow shows a strong seasonality, while mild seasonal variation is indicated for bottom flow. During winter, surface flow in the Bight appears to be predominantly to the southwest, away from the coast. At other times flow tended northward. The preliminary studies did not incorporate the findings of water circulation patterns, in detailed analysis of the distribution of important constituents of the discharged waste in either the water column or the benthos.

Evident, however, is that the extent of dispersion and movement of waste materials in the Bight relates to water circulation. The studies have shown the presence of high concentrations of organic materials in the sediments of the dumping grounds and surrounding areas which correlates well with the distribution pattern of coliform bacteria and heavy metals. The slowly settling sewer sludge generally moves northward, resulting in the deposition of organic material for some distance to the north and northeast of the dumping grounds.

Circulation patterns in the Bight which were obtained by the use of drifters, although useful for indicating the onshore component of net water transport, cannot be correlated effectively to an isotropic dispersion, seasonal variances, or transport mechanisms of waste materials of diverse physical properties. Similarly, such drifter studies cannot 
quantify dispersion of wastes or correlate to water quality without considering the wastes' travel time and degree of dilution. The absence of a thick waste layer in the present dumping grounds, indicated by the few cores which were taken, suggests rapid degradation and assimilation of the organic constituents of the waste, or lateral transport, or a downslope transport into the upper parts of the Hudson Canyon. Improved knowledge of the bottom and surface water circulation of this area, and use of tracers will be required to determine the dispersion patterns and the ultimate fate of waste materials dumped in the New York Bight.

\section{Effects on Sediment and Water Characteristics - Chemical studies} provided data on the concentrations of important chemical substances in the sediments and waters of the Bight dumping grounds and adjacent areas. Determinations were made of the concentrations of phosphorus (ortho, organic, meta, and total), nitrate, total iron, dissolved oxygen, and chlorophyl1-a in water samples. Temperature, salinity, turbidity and $\mathrm{pH}$ were measured. Sediment samples were analyzed for heavy metals and organic content.

The chemical studies determined that waste disposal results in an increase in the nutrient concentration of the waters of the dumping grounds and that the biochemical oxygen demand of the wastes during summer reduces the dissolved oxygen concentration of bottom waters. The studies defined areas with high carbonaceous content in the sediments, and correlated such carbon-rich deposits with sewage and dredge spoils dumped in the area, and with anomalously high concentration of heavy metals such as silver, chromium, cadmium, copper, lead, nickel, and zinc.

Within the dumping grounds, concentrations of heavy metals exceeded background values in other regions of the New York Bight. Heavy metal concentrations greater than background were similarly found along the upper part of the Hudson Canyon indicating movement of waste material by bottom currents. Chemical studies conducted to date, although qualitatively useful, can be regarded as preliminary.

Variations between studies in the estimates of the size and shape of the waste-affected areas are attributed to different criteria used, limitations of sampling, and differences in analytical procedures. The data which have been produced, however, will be useful for further investigations. On the basis of present data, it can be concluded, at least in qualitative terms, that ocean dumping has changed the chemical characteristics of the waters and sediments of the dumping grounds and adjacent areas, and that concentrations of certain parameters, especially heavy metals, bacteria and organics exceed permissible limits. The adverse effect is more pronounced near the bottom-sea interface.

Effects on Regional Ecology - Benthic meiofauna and macrofauna, zooplankton, finfish and bacteria were studied. These studies reached the following general conclusions: 
(a) Benthic fauna in the immediate area of the dumping grounds is directly affected by the dumping activities. The reduced number of animals suggest that ocean dumping may have an adverse impact principally on the meiofaunal communities of the dumping grounds which are food resources for some marine fishes. Some benthic communities are affected primarily by suffocation due to burial from the constant shower of waste materials, and by reduction of the dissolved oxygen concentration of bottom waters resulting from the wastes biochemical oxygen demand. The economic and ecological importance of benthic communities in the area have been difficult to assess. On the basis of data obtained, it is concluded that higher concentrations of pollutants may destroy the meio= fauna, and that meiofaunal animals are not indefinitely insensitive to environmental deterioration. On the basis of present knowledge, however, the relationship cannot be quantified.

(b) No short-term adverse effects have been observed on free floating or swimming marine organisms. No effects were observed on zooplankton species composition and distribution. Reported inhibition in the growth of phytoplankton has not been substantiated. Similarly no apparent adverse effects on fish abundance or species diversity were observed, but due to physical limitations on sampling, such investigations are considered inconclusive.

(c) Coliform bacteria were found in high concentrations in the immediate area of the dumping grounds. The pattern of distribution of such bacteria generally corresponded with that of heavy metals and organic materials in the sediments. The possibility of pathogenic damage to finfish, she1l fish, and other important species, carries important implications requiring additional extensive field and laboratory investigations. In view of the possible human hazard that could result from eating seafood that may carry pathogens, it is recommended that studies of pathogenic bacteria in the New York Bight be given high priority.

(d) The adverse biological effects of heavily polluted dredge spoils may be more severe than those of sewage sludge.

(e) The long-term biological effects of toxic materials remain undetermined.

The biological studies, although comprehensive in some respects, have not answered many questions. The limited program of data collection has not permitted the statistical treatment necessary for the evaluation and quantification of the ecologic effects resulting from ocean dumping. The absence of ecological base-1ine data, the long history of disposal activities, and uncertainty concerning specific criteria for assessing adverse biological effects, in addition to the limited funding provided for these studies, have mitigated against drawing specific conclusions.

Comprehensive Conclusions - The studies supported by CERC generated valuable data related to the disposal of sewage sludge, dredge spoils, and acid-iron wastes, and have helped provide a more detailed and accurate 
environmental description of the New York Bight dumping grounds than had been available. These data suggest that the large volume of wastes being dumped in the Bight and frequency of dumping has changed the marine environment of the dumping grounds and adjacent areas. The possibility of pathogenic and chemical damage to finfish and shellfish from the disposal of waste materials, is a point which has not been answered but which carries health implications requiring extensive field and laboratory investigations.

Complex physical, chemical, and biological processes and interactions, which are not completely understood, are at work and are responsible for the accumulation, dispersion dilution, biodegradation, or removal of wastes materials and their components from the marine environment of the New York Bight. Although preliminary, research work has contributed to a basic understanding of the environmental impact of dumping in the present waste disposal grounds of the New York Bight, it has left many questions unanswered and has raised new questions. This work has assumed that most of the observed adverse effects on the marine environment of the Bight are the direct result of ocean dumping, while other important sources of pollution are known to exist. Although it is difficult to assign responsibility to any class of pollutants, untreated sewage from coastal sources, agricultural and urban runoff, atmospheric precipitants, thermal discharges, and oil spills may all be responsible for adverse environmental effects in the New York Bight. The areal extent and magnitude of change resulting from ocean dumping and from other sources of pollution in the Bight remain to be demonstrated, separated, and quantified.

Due to the limited scope and funding of the short-term investigations completed to date, the long history of waste disposal, and the absence of base-line data, the basic mechanisms by which ecological changes occur in the marine environment of New York Bight remain essentially unknown. Comprehensive, long-term, interdisciplinary studies will be required to determine the extent of these changes.

On the basis of data obtained to date, it is not recommended that the dumping grounds of the New York Bight be shifted to new locations on or beyond the Continental Shelf without adequately studying the long-term effects of waste disposal on the marine environment.

When the use of present sites is discontinued, the sites should be studied thoroughly for several years to assess the degree and rate of changes. Such a program could yield much data on the recovery of the present spoil grounds, and provide information useful in managing waste disposal. 



\section{LITERATURE CITED}

ADVANCED WASTE TREATMENT RESEARCH, "Advanced Waste Treatment," Summary Report, No. 19, 96, 1968.

ALLAN HANCOCK FOUNDATION, "An Investigation on the Fate of Organic and Inorganic Wastes Discharged into the Marine Environment and their Effects on Biological Productivity," Publication No. 29, California State Water Quality Control Board, Sacramento, Calif., 1965.

APPELL, H.R., et a1., "Converting Organic Wastes to Oil," Report of Investigations 7560, U.S. Bureau of Mines, Washington, D.C., 1971.

ATLAS, R., "Distribution of Oil Degrading Microorganisms in Raritan Bay," Unpublished Progress Report, Department of Microbiology, Rutgers University, New Brunswick, N.J., 1972 .

BARBER, R.T., and D. KRIEGER, "Growth of Phytoplankton in Waters from the New York City Sludge Dumping Grounds," 33rd Annual Meeting of ASLO, 1970.

BAXTER, S.C., "Sludge Disposal in Philadelphia," Journal of the Sanitary Engineering Division, ASCE, Vo1. 85, No. SA6, Nov. 1959, p. 127.

BAXTER, S.C., et al., "Philadelphia's Ocean Sludge Disposal Experience and Studies," 44th Annual Conference of the Water Polzution Control Federations 1971.

BEYER, F., "The Spreading of Sinking Pesticides in the Sea," Sewage and Industrial Wastes, Vol. 27, No. 9, Sept. 1955, p. 1073-80.

BOWEN, H.J.M., Trace EZements in Bio-Chemistry, Academic Press, New York, 1963.

BOWMAN, J.M., and P.K. WEYL, "Hydrographic Study of the Shelf and Slope Waters of New York Bight," Technical Report No. 16, Marine Sciences Research Center, State University of New York, Stony Brook, N.Y., Aug. 1972 .

BREHMER, M.L., et a1., "A Study of the Effects of Dredging and Dredge Spoil Disposal on the Marine Environment," Special Scientific Report No. 8, Virginia Institute of Marine Science, Gloucester Point, Va., 1967.

BROOKS, N.H., "Turbulent Diffusion of a Sewage Field," Paper presented to the American Society of Civil Engineering, 1957.

BROOKS, N.H., CARLSON, D.E., and KOH, R.C.Y., "Function of Outfall and Dilution in Puget Sound," and "Disposal of Digested Sludge to Puget Sound," Report Submitted to METRO, Seattle, Wash., 1965.

BUELOW, R.W., "Ocean Disposal of Waste Materia1," Transactions of the National Symposium on Deean Sciences and Engineering of the Atlantic Shelf, Marine Technology Society, 1968, pp. 311-337. 
BUELOW, R.W., PRINGLE, B.H., and VERBER, J.L., "Preliminary Investigation of Waste Disposal in the New York Bight," Northeast Marine Health Science Laboratory, U.S. Public Health Service, 1968.

BUMPUS, D.F., "Residual Drift Along the Bottom on the Continental She1f in the Middle Atlantic Bight Area," Limnology Oceanography, No. 10, Supp1. 2: R50-R53, 1965.

BUMPUS, D.F., and LAUZIER, L.M., "Service Circulation on the Continental Shelf Off Eastern North America Between Newfoundland and Florida," Serial Atlas of the Marine Environment, Folio ?, American Geographical Society, New York, N.Y., 1965.

BUREAU OF NATIONAL AFFAIRS, INC., "New York vs. Department of the Army," Environmental Reporter, No. 49, Apr. 1972.

BUTCHER, R.W., "Relation Between the Biology and the Polluted Condition of the Trent," Verhandl. Int. Ver. Limnol, 12:823-7, Cali fornia State Water Quality Control Board, 1964, Publication No. 26, 1955.

CARLISELE, J.G., "Results of a Six Year Trawl Study in an Area of Heavy Waste Discharge: Santa Monica Bay, California," California Fish and Game, 55 (1), 1969.

CARLSON, D.E., and ZICHEFOOZE, C.S., "Factors Affecting Coliform Reduction in Chlorination of Digested Sludge," Appendix E, "Disposal of Digested Sludge to Puget Sound," METRO, Seattle, Wash., July 1965.

CITY OF PHILADELPHIA, "Annual Report," 1968.

CIVIL ENGINEERING, "Sludge Disposal at Sea," Civil Engineering, Vo1. 38, Aug. 1968, p. 62-3.

CONOMOS, T.J., et al., "Movement of Seabed Drifters in the San Francisco Bay Estuary and the Adjacent Pacific Ocean," Circular 637-B, U.S. Geological Survey, Washington, D.C., 1970.

CORWIN, N., and KETCHUM, B.H., "The Iron Content of Sediment Samples in New York Bight Obtained During R. V. Caryn Cruise 108, Oct. 19-24, 1956," Civil Engineering, Woods Hole Oceanographic Institution Reference No. $57-19,1968$.

COUNCIL ON ENVIRONMENTAL QUALITY, "Ocean Dumping - A National Policy," A Report to the President, Oct., 1970.

CRONIN, L.E., "The Role of Man in Estuarine Processes," Proceedings of the American Association for the Advancement of Science, on Estuaries, 1967.

CRONIN, L. E., et al., "Interim Report on Gross Physical and Biological Effects on Overboard Spoil Disposal," Reference No. 67-34, Chesapeake Bay Biology Laboratories, 1967. 
DOLE, R.B., and STABLER, H., "Denudation," Water Supply Paper, 234, 85, U.S. Geological Survey, Washington, D.C., 1909.

ENVIRONMENTAL PROTECTION AGENCY, "Water Quality Standards," Criteria Digest, Washington, D.C., Aug. 1972.

ENVIRONMENTAL SCIENCE AND TECHNOLOGY, "Building Bricks from the Waste Pile," Environmental Science and Technology, Vol. 6, No. 6, June 1972, p. 502 .

FEDERAL WATER POLLUTION CONTROL ADMINISTRATION, "Problems of Combined Sewer Facilities and Overflows," Water Pollution Control Research Series WP-20, Government Printing Office, Washington, D.C., July 1968.

FEDERAL WATER POLLUTION CONTROL ADMINISTRATION, "The Nationa1 Estuarine Pollution Study," Vols. I, II, and III, U.S. Department of Interior, Washington, D.C., Nov. 1969.

FLORIDA OCEAN SCIENCES INSTITUTE, "Limitations and Effects of Waste Disposal on an Ocean Shelf," Water Pollution Control Research Series 16070EFG12/71, Environmental Protection Agency, Washington, D.C., 1971.

GELBERMAN, J, "A Proposed Interior Disposal Area for Dredged Materials and Incineration Residue in Lower New York Harbor," Informal Report, Operations Division, U.S. Army Engineer District, Corps of Engineers, New York, N.Y., 1972.

GIBSON, L.B., "Some Unifying Characteristics of Species Diversity," Cont. Cushman Found. Foram, 1966, pp. 117-124.

GREENBERG, A.E., "Surviva1 of Enteric Organisms in Sea Water," Rpt. 71 (1), U.S. Public Health Report, 1956.

GROSS, M.G., "A Major Source of Marine Sediment," Technical Report No. 2, Marine Sciences Research Center, State University of New York, Stony Brook, N.Y., Sept. 1969.

GROSS, M.G., "Preliminary Analyses of Urban Wastes, New York Metropolitan Region," Technical Report No. 5, Marine Sciences Research Center, State University of New York, Stony Brook, N.Y., Feb. 1970 (NTIS Acquisition No. $A D 746$ 959).

GROSS, M.G., Water Resources Research, No. 6, 927, 1970.

GROSS, M.G., "Analysis of Dredged Wastes, Fly Ash, and Waste Chemicals, New York Metropolitan Region," Technical Report No. 7, Marine Sciences Research Center, State University of New York, Stony Brook, N.Y., Feb. 1970 (NTIS Acquisition No. AD 734 337).

GROSS, M.G., "Waste-Solid Disposal in Coastal Waters of North America," Informal Report, State University of New York, Marine Sciences Research Center, Stony Brook, N.Y., 1970. 
GROSS, M.G., MORSE, B.A., and BARNES, C.A., "Movement of Near-Bottom. Waters on the Continental Shelf off the North-Western United States," Journal of Geophysical Research, 74 (28):7044-7, 1969.

GROSS, M.G., et a1., "Survey of Marine Waste Deposits, New York Metropolitan Region," Technical Report No. 8, Marine Sciences Research Center, State University of New York, Stony Brook, N.Y., 1971 (NTIS Acquisition Number AD 723 431).

GUARINO, C.F., "Sludge Disposal by Barging to Sea," W\&SW, Vo1. 114, Nov. 1967, pp. R126-7.

GUSTAFSON, C.G., "PCB's Prevalent and Persistent," Environmental Science and Technology, Vol. 4, No. 10, Oct. 1970, pp. 814-19.

HARRISON, J., "An Evaluation of a Heat Syneresis Process on Domestic U.S. Sewage Sludges," Ph.D. Dissertation, Virginia Polytechnic Institute, Blacksburg, Va., 1967.

HARRISON, W., "Environmental Effects of Dredging and Spoil Deposition," First World Dredging Conference Proceedings, May 6-8, 1967, pp. 535-560.

HARRISON, W., et al., "Circulation of Shelf Waters off the Chesapeake Bight. Surface and Bottom Drift of Continental Shelf Waters Between Cape Henlopen, Delaware, and Cape Hatteras, North Carolina, June 1963 - Dec. 1964,": ESSA Professional Paper, No. 3, 1967.

HERMAN, S.S., "Vertical Migration of the Opossum Shrimp, Neomysis amemicana Smith," Limnology Oceanography, 1963, 8 (2):228-38.

HLAVKA, G.E., "Measuring Some of Man's Effects on the Southem Califomia Coastal Marine Environment," Report to the Institute of Electric and Electronic Engineers International Conference on Engineering in the Ocean Environment, $1971,11 \mathrm{p}$.

HOLEMAN, J.N., Water Resources Research, 4, 737, 1968.

HORNE, R.A., MAHLER, A.J., and ROSELLS, R.C., "The Marine Disposal of Sewage Sludge and Dredge Spoil in the Waters of the N.Y. Bight," Technical Memo 1-71, Woods Hole Oceanographic Institution, Woods Hole, Mass., Jan., 1971, (NTIS Acquisition Number AD 722 791).

HUME, N.B., GUNNERSON, C.G., and IMEL, C.E., Joumal of Water PolZution Control Federation, 34, 15, 1962.

HUME, N.B., and GARBER, W.F., "Marine Disposal of Digested Screened Waste Water Solids," Third Intemational Conference on Water Pollution Research, Paper No. 12, Sec. III, Munich, Germany, 1966. 
ISAACS, P.C.G. "Biological Problems in Water Pollution," Publication 999-WP-25, U.S. Public Health Service, 1962.

JEFFRIES, H.P., "Plankton Biology of Raritan Bay," Ph.D. Thesis, Rutgers University, New Brunswick, N.J., 1959.

JEFFRIES, H.P., "Environmental Characteristics of Raritan Bay, A Polluted Estuary," Limnology Oceanography, 7, 21, 1962.

JEFFRIES, H.P., Proceedings of the Annual Northeastem Regional Antipolzution Conference, 84, University of Rhode Island, Kingston, R. I., 1968.

JONES, P., and FOLKARD, A., "Hydrographic Observations in the Eastern Irish Sea with Particular Reference to the Distribution of Nutrient Salts," Journal of the Marine Biology Association, U. K. 51, 1971, pp. 159-182.

KAISER ENGINEERS CONSORTIUM, Final Report, San Francisco Bay - Delta Water Quality Control Program, California State Water Resources Control Board, Sacramento, Calif. 1969.

KETCHUM, B.H., "Eutrophication of Estuaries, Eutrophication: Causes, Consequences, Correctives," Proceedings of a Symposium, National Academy of Science, Washington, D.C., 1969, pp. 197-208.

KETCHUM, B.H., "Ecological Effects of Sewer Sludge Disposal at Sea," Paper presented at the Water Pollution Control Federation Convention, Session \#16, Boston, Oct, 1970.

KETCHUM, B.H., Testimony Before the Subcommittee on Acid Water Pollution, 1970.

KETCHUM, B.H., and FORD, W.L., "Waste Disposal at Sea, Preliminary Report on Acid-Iron Waste Disposal," Report to National Research Council, Woods Hole Oceanographic Institution, Woods Hole Mass., June, 1948.

KETCHUM, B.H., REFFIELD, A.C., and AYERS, J.C., "The Oceanography of the New York Bight," Physical Oceanographic Meteorology, MIT-WHOI, $12,1,1951$.

KETCHUM, B.H., VACCARO, R.F., and CORWIN, N., Joumal of Marine Research $17,282,1958$.

KETCHUM, B.H., YENTSCH, V.S., and CORWIN, N., "Some Studies of the Disposal of Iron Wastes at Sea," Woods Hole Oceanographic Institution Ref. No. 58-55, Woods Hole, Mass., 1958.

KLEIN, L., "River Polzution," Vols. 1-3, Plenum Pub. Corp., New York, $1962,1966$.

KUPFERMAN, S., and MURPHY, L., "A Preliminary Investigation of Characteristics of Philadelphia's Digested Sewage Sludge," Technical Notes, College of Marine Studies, University of Delaware, Newark, Del., Mar. 1973. 
MacKAY, D.W., and TOPPING, G., "Preliminary Report on the Effects of Sludge Disposal at Sea," Effluent and Water. Treatment, 5, 1970, pp.

MacKAY, D.W., HALCROW, W. and THORNTON, I., "Sludge Dumping in the Firth of Clyde," Marine PolZution Bulzetin, 3 (1), 1972, pp. 7-10.

MAHONEY, J.B., MIDLIGE, F.H., and DEUEL, D.G., "A Fin-Rot Disease of Marine and Euryhaline Fishes in the New York Bight," Manuscript Submitted to Trans. Amer. Fish. Soc., 1972.

MANN, K.H., "Analysis of Aquatic Ecosystems," Essays in Hydrobiology, Exeter Univ. Press, 1971.

MARINE POLLUTION BULLETIN, "Sewage Discharges into the Bosphorus," Marine Pollution Bulletin, Vol. 3, No. 9, Sept. 1972, p. 133.

MARMER, H.A., "Tides and Currents in New York Harbor," Spec. Pub. No. 111, U.S. Department of Commerce, Coast \& Geodetic Survey, Washington, D.C., 1935.

McCRONE, A.W., Journal of Sedimentary Petrology, 37, 475, 1967.

McKINNEY T.F., and FRIEDMAN, G.M., "Continental Shelf Sediments of Long Island, Journal of Sedimentary Petrology, Vol. 40, No. 1, 1970, pp. 213-248.

MEADE, R.H., "Landward Transport of Bottom Sediments in Estuaries of the Atlantic Coastal Plain," Journal of Sedimentary Petrology, Vo1. 39, No. 1,1969 , p. 222-234.

NORTH, N.J., "Ecology of the Rocky Nearshore Environment in Southern California and Possible Influences of Discharged Wastes," International Conference on Water Pollution Research, Pergamon Press, London, 1962.

ORLOB, G.T., "Effects of Digested Sludge Discharge on the Ocean Environment Near the City of San Diego Outfall," Report to San Diego Regional Water Pollution Control Board, Aug. 1965.

PANUZIO, F.L., "Lower Hudson River Siltation," Proceedings of the Federal Inter-Agency Sediment Conference, Misc. Pub1. No. 970, Agricultura1 Research Series, 1965.

PEARCE, J., "The Effects of Waste Disposal in the New York Bight," Interim Rpt., Sandy Hook Marine Laboratory, U.S. Bureau of Sport Fisheries and Wildlife, Dec. 1969.

PERKINS, GILCHRIST, ABBOTT, Nature, London, 238:101-3, 1972.

PIPPY, J.H.C., and HARE, G.M., "Relationship of River Pollution to Bacterial Infection in Salmon (Salmo salar) and Suckers (Catostomus commersoni)," Transactions of the American Fisheries Society, 98 (4), 1969 , pg. 685-690. 
POLYANSKII, T.I., "Parasites of the Fish of the Barents Sea," TT 66-51047, Trans. Zool. Inst. Acad. Sci., USSR, Vol. 19, 1955.

REDFIELD, A.C., and WALFORD, L.A., "A Study of the Disposal of Chemical Wastes at Sea," Publ. No. 201, National Academy of Science, National Council, 1951 .

RYTHER, J., and DUNSTAN, W., "Nitrogen, Phosphorus and Eutrophication in Coastal Marine Areas," Science, 171:1008-13, 1971.

SAILA, S.B., "Results of Studies Related to Dredged Sediment Dumping in Rhode Island Sound," Proceedings of the Annual North Eastern Regional Antipollution Conference, University of Rhode Island, Kingston, R.I., 1968.

SAILA, S.B., PRATT, S.D., and POLGAN, T.T., "Providence Harbor Improvement Spoil Disposal Site Evaluation Study, Phase II," University of Rhode Island, Kingston, R.I., May 1971.

SANDY HOOK MARINE LABORATORY, "The Effects of Waste Disposal in the New York Bight," Nine Sections, (NTIS Acquisition Numbers AD 739531 through AD 739539); Summary Final Report (AD 743936), May 1972.

SEGAL, E., "Marine Ecology," Vo1. 1, Environmental Factors, Part 1, Wiley, New York, 1970, pp. 159-211.

SERVIZI, J.A., GORDON, R.W., and MARTENS, D.W., "Marine Disposal of Sediments from Bellingham Harbor as Related to Sockeye and Pink Salmon Fisheries," International Pacific Salmon Fisheries Commission, Progress Report No. 23, 1969.

SHElTON, R.G.U., "Sludge Dumping in the Thames Estuary," Marine PolZution BuzZetin, Vo1. 2, No. 2, Feb. 1971, pp. 24-27.

SMITH, D.D., and BROWN, R.P., "On Appraisal of Oceanic Disposal of BargeDelivered Liquid and Solid Wastes from U.S. Coastal Cites," Prepared by Dillingham Corporation for Department of Health, Education and Welfare, Bureau of Solid Waste Management, Contract No. PH 86-68-203, 1970.

SMITH D.D., and BROWN R.P., "Ocean Dumping of Barge-Delivered Liquid and Solid Wastes from U.S. Coastal Cities," Solid Waste Management Office, U.S. Environmental Protection Agency, Washington, D.C., 1971.

SMITHSONIAN ADVISORY COMMITTEE, "Smithsonian Advisory Committee Report on Studies of the Effects of Waste Disposal in the New York Bight," NTIS Acquisition Number AD 746 960, 1972.

SPERRY RAND CORPORATION, "Ocean Waste Dumping Operations Monitoring," Sperry Systems Management Division, 1971, (NTIS Acquisition No. $A D$ 735378). 
SYLVESTER, R.O., "Sludge Disposal by Dilution in Puget Sound," Journal of Water PolZution Control Federation, Vo1. 34, No. 9, Sept. 1962, pp. 891-900.

TORPEY, W.N., "Response to Polution of New York Harbor and Thames Estuary," Journal of Water PolZution Control Federation, Vol. 39, No. 11, 1967, p. 1797 .

TRAIN, R.E., CAHN, R., and MacDONALD, G.J., "Ocean Dumping," Council on Environmental Quality, U.S. Government Printing Office, Washington, D.C., 1970.

U.S. ARMY, CORPS OF ENGINEERS, "Dredging and Water Quality Problems in the Great Lakes," (12) Vols.), Engineer District, Buffalo, N.Y., June 1969.

U.S. ARMY CORPS OF ENGINEERS, "Dredge Disposal Study for San Francisco Bay and Estuary, A Preliminary Report on Main Ship Channe1," Engineer District, San Francisco, Calif., 1971.

U.S. DEPARTMENT OF THE INTERIOR, Ad Hoc Committee for the Evaluation of The Influence of Dumping in the New York Bight, Draft Report, Washington, D.C., Apr. 1970.

U.S. FISH AND WILDLIFE SERVICE, "Effects on Fish Resources of Dredging and Spoil Disposal in San Francisco and San Pablo Bays, California," Department of the Interior, Washington, D.C., Nov. 1970.

U.S. HOUSE OF REPRESENTATIVES, "Marine Protection, Research, and Sanctuaries Act of 1971," H.R. 9727, 92D Congress, 1st Session, July 1971.

WALTER, L., "Composition of Sewage and Sewage Effluents," Water and Sewage Works, Part 2, 1961, p. 478.

WESTLEY, R.E., et al., "A Preliminary Evaluation of the Toxicity of the Bottom Sediments of Olympia Harbor," State of Washington, Department of Fisheries, Apr. 1972.

WILDER, "The Relative Toxicity of Certain Metals to Lobsters," Joumal of the Fisheries Research Board, Canada, 8 (7):486-7, 1952.

WILHM, J.L., "Comparison of Some Diversity Indices Applied to Populations of Benthic Macroinvertebrates in a Stream Receiving Organic Wastes," Journal of the Water Pollution Control Federation 39, No. 10, 1967, pp. 1673-83.

WILHM, J.L., and DORRIS, T.C., "Species Diversity of Benthic Macroinvertebrates in a Stream Receiving Domestic and 0il Refinery Effluents," Amer. Mid. Natur., Vol. 76, No. 2, 1966, pp. 427-49.

WILHM, J.L., and DORRIS, T.C., "Biological Parameters for Water Quality Criteria," Bioscience, Vo1. 18, No. 6, 1968, pp. 477-81. 
WILLIAMS, S.J., "Geologic Framework of Inner New York Bight - Its Influence on Positioning Offshore Engineering Structures," Abstract, Geologic Society of America, 1973.

WILLIAMS, S.J., and FIELD, M.E., "Sediments and Shallow Structures of the Inner Continental Shelf off Sandy Hook, New Jersey," Abstract, Northeast Section, Geological Society of America Meeting, 1971.

WILLIAMS, S.J., and DUANE, D.B., "Sediments and Shallow Structure of the Inner New York Bight, Unpublished Manuscript, Technical Manual, U.S. Army Coastal Engineering Research Center, Washington, D.C., 1973.

WUESTEFELD, R.H., "Waste Disposal in the Coastal Waters of New York Harbor," Paper Presented at Joint Meeting: New York Water Pollution Control Association and ASCE, Dec. 1967.

WYATT, B., BURT, W., and PATTULLO, M., "Surface Currents off Oregon as Determined from Drift Bottle Returns," Journal of Physical Oceanography, Vo1. 2, July 1972, pp. 286-293. 

DOCUMENT CONTROL DATA - R \& D

(Security clessification of tille, body of abstract and indexing annofation must be entered when the overall report ts classtlled) 1. ORIGINATING ACTIVITY (Corporato author)

Department of The Army

Coastal Engineering Research Center (CERC)

Kingman Buịlding

Fort Belvoir, Virginia 22060

3. REPORT TITLE

OCEAN DUMPING IN THE NEW YORK BIGHT: AN ASSESSMENT OF ENVIRONMENTAL STUDIES

4. DESCRIPTIVE NOTES (TYPA of raport and incluatve datas)

5. AUTHOR(S) (Firot nama, alddle initial, last noma)

George Pararas-Carayannis

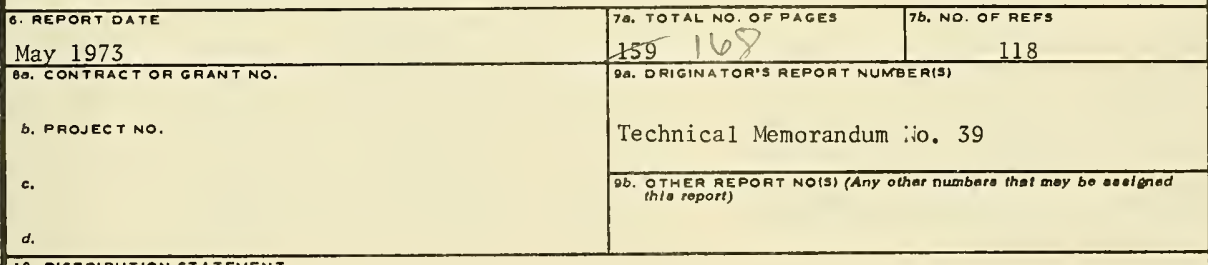

10. OISTRIBUTION STATEMENT

Approved for public release; distribution unlimited.

\begin{tabular}{|l|l|}
\hline 11. SUPPLEMENTARY NOTES & $\begin{array}{l}\text { 12. SPONSOAING MILITARY ACTIVITY } \\
\text { Department Of the Army }\end{array}$ \\
Coastal Engineering Research Conter \\
Kingman Building \\
Fort Belvoir, Virginia 22060
\end{tabular}

Short-term studies on effects of ocean dumping in the New York Bight were contracted by CERC. Studies included hydrographic, geological, chemical, biological investigations, and a feasibility study for a remote-controlled electronic sensing system to detect the location and dump status of waste disposal vessels. Circulation patterns were estimated by current meters and by seabed and surface drifters. Chemical analyses were made of the concentration of phosphorus, nitrate, total iron, dissolved oxygen, and chlorophyll-a. Temperature, salinity, turbidity and pH were measured. Scdiment samples were analyzed for organic content and the heavy metals; and biological samples for heavy metals and mercury. Included are studies of benthic meiofauna and macrofauna zooplankton, finfish and bacteria and disposal of sewage sludge, dredge spoils and acid-iron wastes. Findings are presented and analyzed for impact on ecology, water quality, and total environmental effects. 


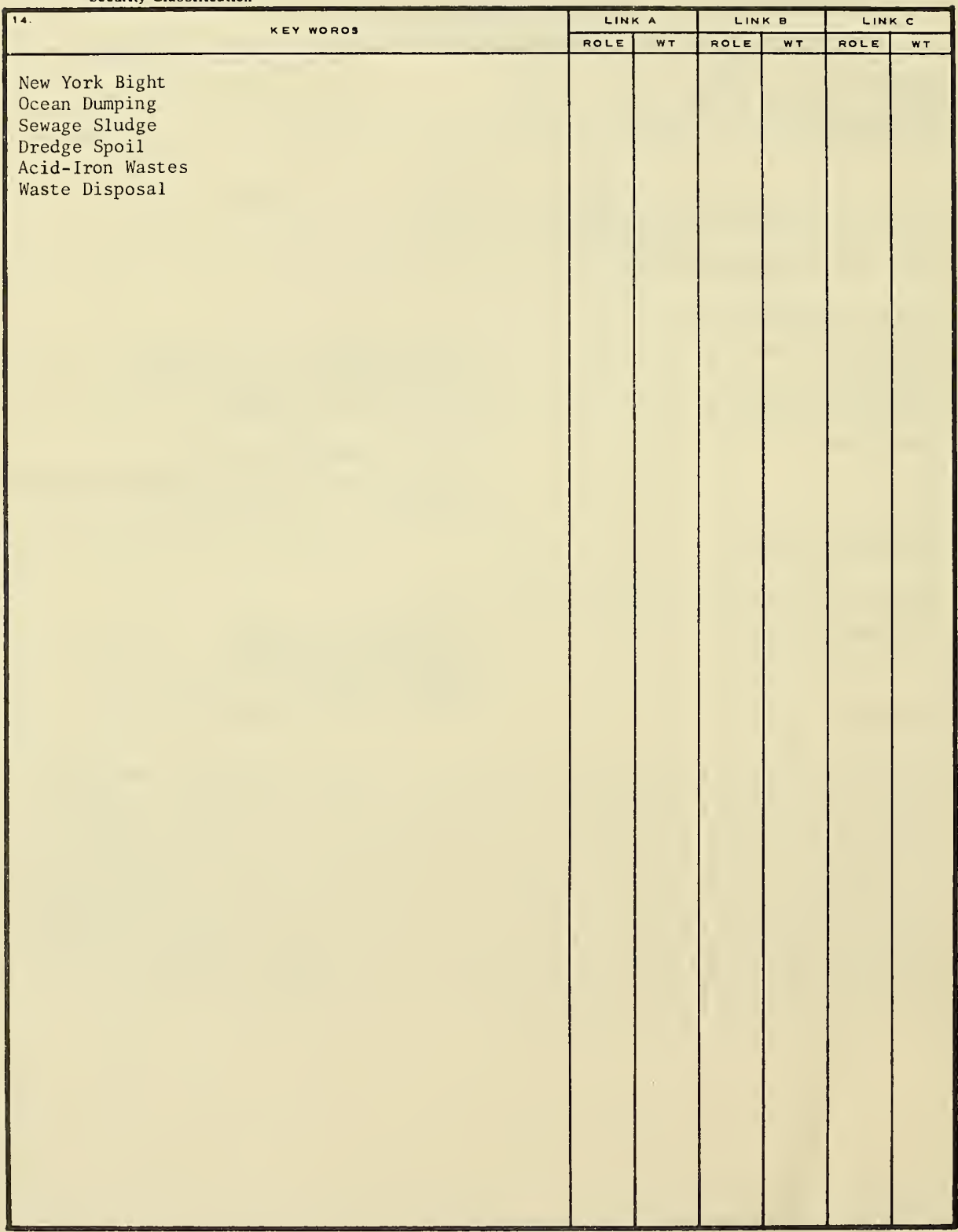





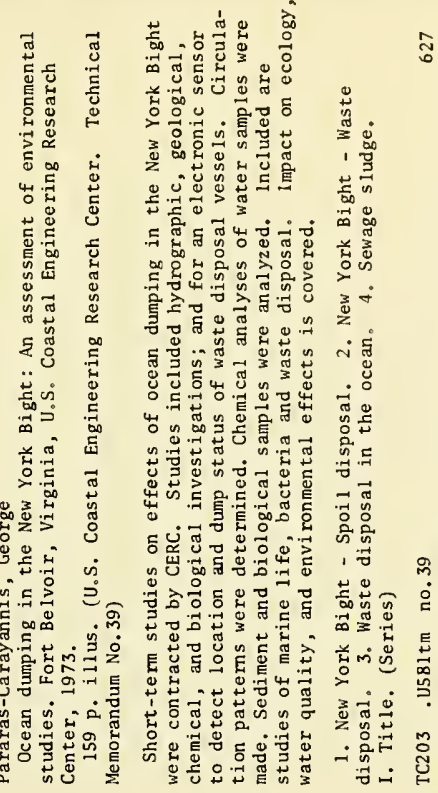

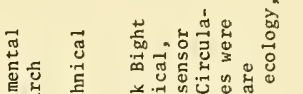

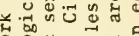

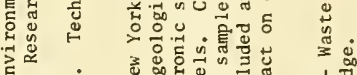

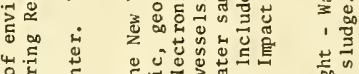

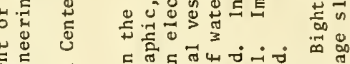

可

罂齿

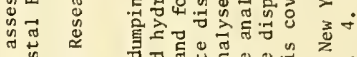

द挠

تं ह

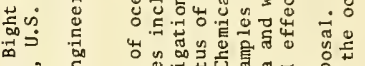

若留

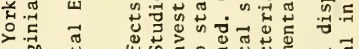

क्⿹

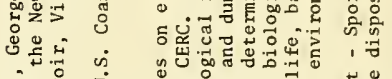

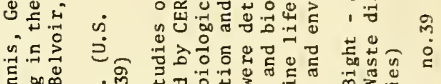

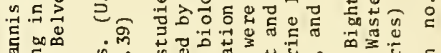

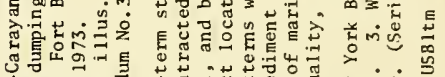

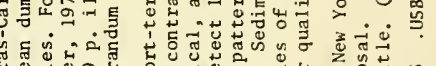

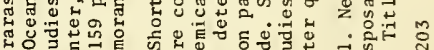

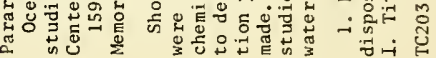

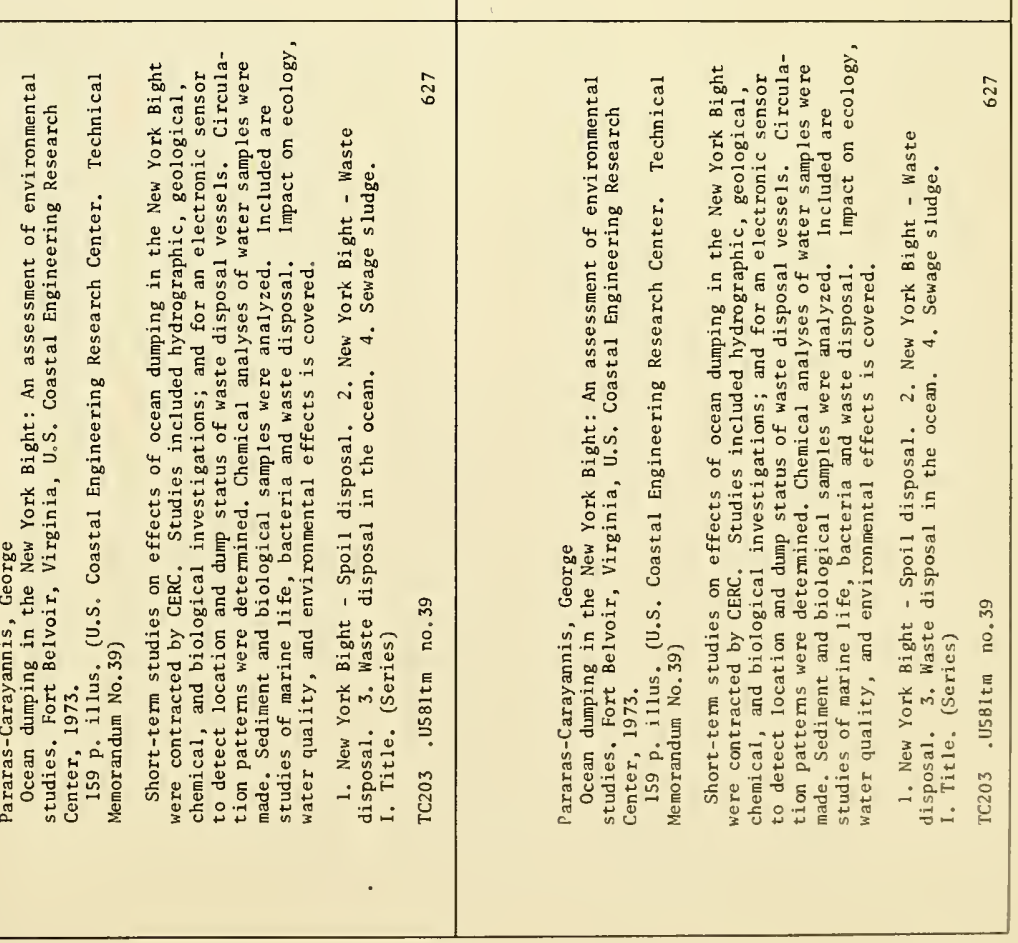




